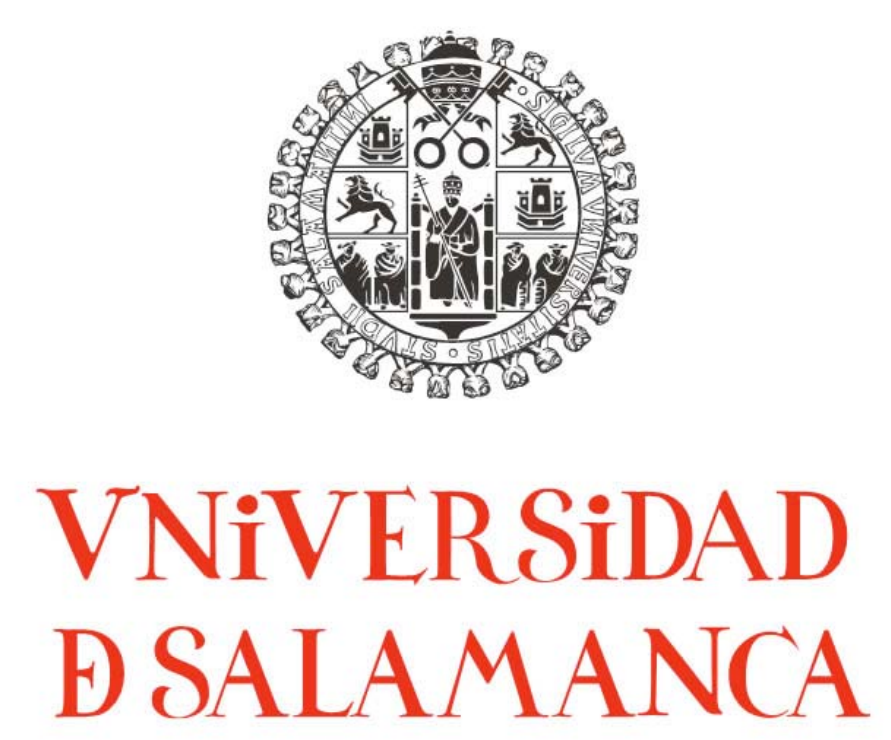

DEPARTAMENTO DE BIOQUÍMICA Y BIOLOGÍA MOLECULAR INSTITUTO DE NEUROCIENCIAS DE CASTILLA Y LEÓN

\title{
ANÁLISIS FUNCIONAL DEL RECEPTOR OPIOIDE MU DEL PEZ CEBRA
}

Memoria presentada por el doctorando Ezequiel Marrón Fdez. de Velasco para optar al título de doctor por la Universidad de Salamanca 



\section{DÑA. RAQUEL E. RODRÍGUEZ, PROFESORA TITULAR DEL DEPARTAMENTO DE BIOQUÍMICA Y BIOLOGÍA MOLECULAR DE LA UNIVERSIDAD DE SALAMANCA}

\section{CERTIFICA:}

Que el presente trabajo, titulado "Análisis funcional del receptor opioide mu del pez cebra" presentado por D. Ezequiel Marrón Fdez. de Velasco para optar al grado de Doctor en Biología, ha sido realizado bajo mi dirección en el Departamento de Bioquímica y Biología Molecular de la Universidad de Salamanca. Hallándose concluido y reuniendo a su juicio las condiciones de originalidad y rigor científico necesarios, autoriza su presentación a fin de que pueda ser defendido ante el tribunal correspondiente.

Y para que así conste, expide y firma la presente certificación en Salamanca, a 13 de mayo de 2008.

Fdo: Raquel E. Rodríguez 

Ezequiel Marrón Fdez de Velasco ha sido becario del Ministerio de Educación y Ciencia durante la realización de este trabajo de investigación (Beca F.P.U. AP2003-4256) 

Agradecimientos 

En primer lugar me gustaría agradecer a mi directora de tesis, Raquel E. Rodríguez ya que sin ella este trabajo no habría sido posible; por todo lo que me ha enseñado, de la ciencia y de la vida, gracias.

Gracias a mis compañeros de laboratorio, de los que he aprendido y a los que he enseñado, los que están y los que hace tiempo se fueron; los largos días de trabajo no son lo mismo sin ellos. Gracias en especial a Iván y a Sergio con los que he disfrutado de largas charlas de Ciencia y de muy buenos momentos. También gracias a los compañeros de Minneapolis, a Vida y Yongjiao por acogerme tan bien y por supuesto a Ping-Yee Law.

Gracias a mi familia por todo, mis logros son vuestros logros.

Gracias a Patricia por estar siempre ahí, por entenderme y apoyarme; lo eres todo para mí.

Gracias a mi "otra familia” por tratarme como a uno más.

Por último gracias a todos aquellos que me han marcado en la vida, por sus enseñanzas, por sus consejos, por su amistad. 



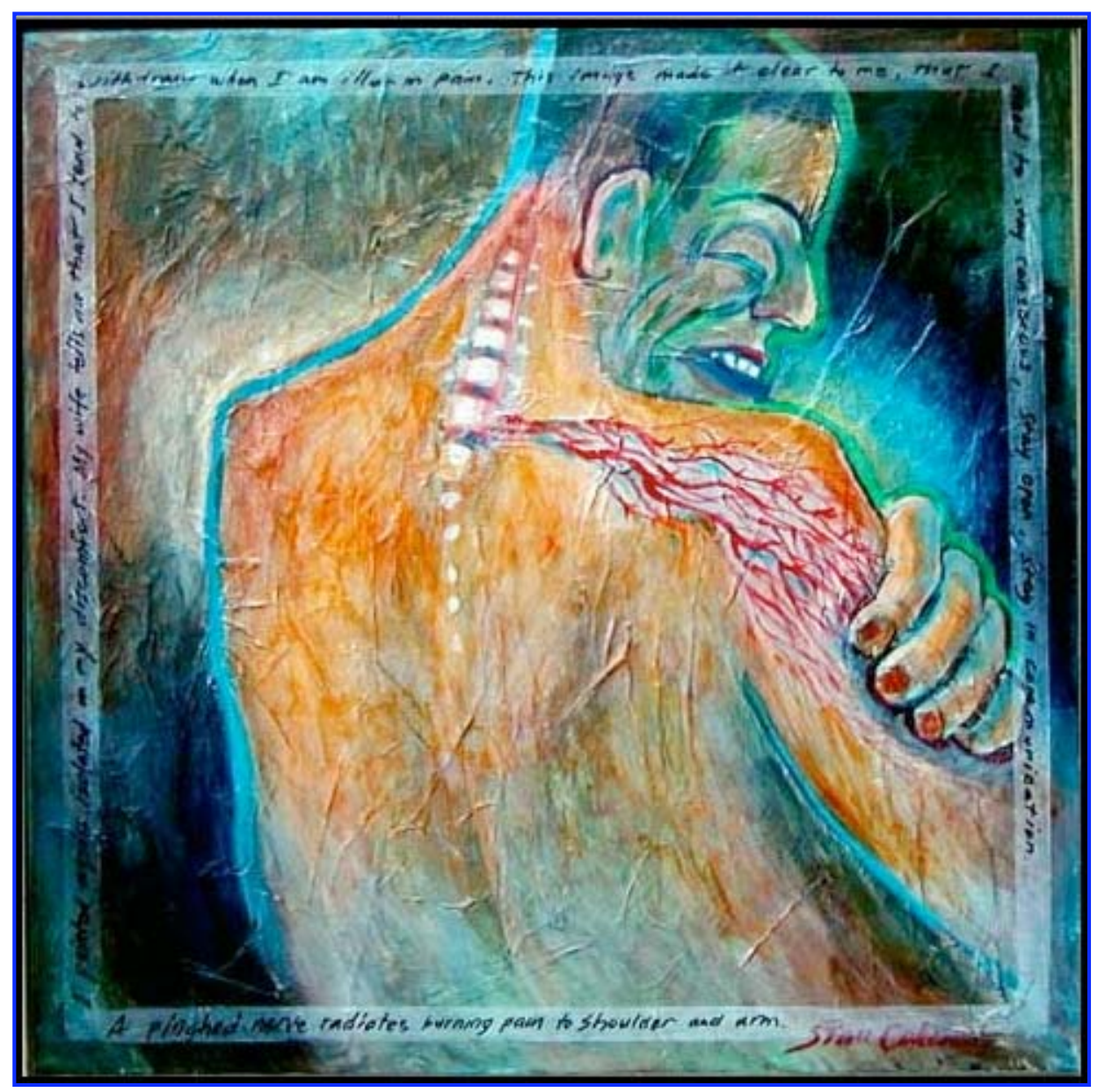

Titulo: $\mathcal{A}$ Stab in the Arm Artista: Stan Cohen

"El dolor es una Guena señal, puesto que te avisa que aún no estas muerto" 

Índíce 

2.1 Dolor 3

2.2 Opioides, perspectiva histórica 3

2.3 Mecanismos de modulación del dolor por el sistema opioide $\quad 8$

2.4 Otros efectos fisiológicos de las sustancias opiáceas 11

$\begin{array}{ll}2.5 \text { Drogodependencia } & 13\end{array}$

$\begin{array}{ll}2.5 .1 \text { Tolerancia } & 13\end{array}$

2.5.2 Dependencia 14

2.6 El receptor opioide $\quad 15$

2.7 Clonación de los receptores opioides 16

2.8 Caracterización molecular de los receptores opioides 18

2.9 Los péptidos opioides $\quad 22$

2.10 Farmacología de los receptores opioides 25

2.11 Análisis de los sistemas de corte y empalme (Splicing) alternativo del $\begin{array}{ll}\text { receptor opioide mu de mamífero } & 27\end{array}$

2.12 Transducción de la señal de los receptores opioides 29

2.13 Desensibilización e internalización de los receptores opioides 32

2.14 Fenotipo de los ratones deficientes en el receptor opioide mu 35

2.15 Modelos animales en la investigación biomédica 37

2.16 El pez cebra: un nuevo modelo experimental 39

2.17 El sistema opioide en el pez cebra $\quad 42$

2.18 zfMOR, el receptor opioide tipo mu de pez cebra 43

2.19 Características de la proteína codificada por zfMOR 45

4.1 Animales de experimentación

4.2 Extracción de RNA total de cerebro pez cebra 53

4.3 Extracción de RNA total de células en cultivo 54 
4.4 Obtención de cDNA 55

4.5 Reacción en cadena de la polimerasa (PCR) $\quad 57$

$\begin{array}{ll}4.6 \text { Electroforesis en gel de agarosa } & 61\end{array}$

4.7 Purificación de los fragmentos amplificados por PCR 62

4.8 Concentración del DNA por precipitación $\quad 64$

4.9 Reacción de digestión $\quad 64$

4.10 Reacción de ligación 65

4.11 Desfosfatación de los plásmidos 66

4.12 Preparación de medios y placas bacterianas 66

4.13 Preparación de células súper competentes 67

4.14 Transformación de células súper competentes 68

4.15 Selección de las colonias transformantes 69

4.16 Purificación del DNA plasmídico $\quad 69$

4.17 Secuenciación automática del DNA 71

4.18 Análisis de las secuencias $\quad 72$

$\begin{array}{ll}4.19 \text { Cultivos celulares } & 73\end{array}$

4.20 Medición de las concentraciones de $\mathrm{CO}_{2}$ en los incubadores $\quad 74$

$\begin{array}{ll}4.21 \text { Transfección } & 75\end{array}$

4.22 Obtención de clones estables $\quad 76$

4.23 Congelación de células HEK-293 77

4.24 Descongelación de células HEK-293 77

4.25 Obtención de membranas de células en cultivo 78

4.26 Ensayos de unión a saturación con radioligandos $\quad 79$

4.27 Ensayos de competición de ligandos por el receptor 81

4.28 Ensayos de actividad del receptor por $\left[{ }^{35} \mathrm{~S}\right]-\mathrm{GTP} \gamma \mathrm{S}$

4.29 Estudio de la inhibición de la adenilato ciclasa 84

4.30 Análisis de los datos 86

$\begin{array}{ll}4.31 \text { Estudios de inmunofluorescencia } & 87\end{array}$

4.32Estudios de citometría de flujo $\quad 89$

5.1 Estudio de la expresión de zfMOR en el pez cebra 95

5.2 Obtención de la construcción de zfMOR 96 
5.3 Transfección de la construcción en células HEK-293

5.4 Prueba de la presencia del receptor zfMOR en las células HEK293

5.5 Experimentos de saturación ligando-receptor

5.6 Experimentos de competencia o desplazamiento

5.7 Estudios de actividad funcional del receptor zfMOR

5.8 Estudio del acoplamiento a la ruta de la adenilato ciclasa

5.9 Obtención de las construcciones marcadas (Tagged)

5.10 Obtención de la construcción mutante

5.11 Estudio comparativo del receptor mutante y el wild type utilizando ${ }^{3} \mathrm{H}$-DAMGO

5.12 Estudio comparativo del receptor mutante y el wild type utilizando AMPc

5.13 Estudio comparativo del receptor mutante y el wild type usando ligandos endógenos

5.14 Estudio de la capacidad de unión del $\mathrm{Zn}^{2+}$ al receptor zfMOR

5.15 Estudios de internalización del receptor mediante inmunofluorescencia

5.16 Estudios de internalización del receptor mediante citometría de flujo

6.1 Existencia de duplicados del gen de zfMOR

6.2 Comparación de zfMOR con otros receptores opioides 158

6.3 Unión de ligandos opioides al receptor 162

6.3.1 Estudios de saturación usando ${ }^{3} \mathrm{H}$-Diprenorfina 163

6.3.2 Estudios de saturación usando ${ }^{3} \mathrm{H}-\mathrm{DAMGO} \quad 164$

6.3.3 Estudios de saturación utilizando otros ligandos opioides 169

6.4 Estudios de competencia o desplazamiento usando ${ }^{3} \mathrm{H}$-Diprenorfina 170

6.5 Estudios de competencia o desplazamiento usando ${ }^{3} \mathrm{H}-\mathrm{DAMGO} \quad 176$

6.6 Ensayos de actividad del receptor por $\left[{ }^{35} \mathrm{~S}\right]-\mathrm{GTP} \gamma \mathrm{S}$

6.7 Estudio de la inhibición de la adenilato ciclasa 191

6.8 Estudio de la capacidad de unión del $\mathrm{Zn}^{2+}$ al receptor zfMOR 194 
10 ANEXO II (Secuencia genómica zfMOR) 
Abreviaturas 

a.C.

$\mathrm{AC}$

ACTH

$\mathbf{B}_{\max }$

BNTX

BSA

BW373U86

CaM Kinasa II

ccMOR

cDNA

CMV

CTAP

CTOP

DADLE

DAMGO

DEPC

DMEM

DMSO

DOGS

DPDPE

dpm

DSLET

$\mathrm{EC}_{50}$

LEC1

LEC2

LEC3

EDTA

EKC

FSC

FSH

GABA

GAPDH

GIRK1

GM

GPCR
Antes de Cristo

Adenilato ciclasa

Hormona adrenocorticotropa

Unión máxima (Bound maximum)

Benzilidenenaltrexona

Albúmina sérica bovina

( \pm )-[1( $\left.\mathrm{S}^{*}\right), 2 \alpha, 5 \beta$ ]-4-[[2,5-Dimetil-4-(2-propenil)-1-piperazinil](3hidroxifenil)metil]-N,N-dietilbenzamida

Proteína kinasa II calcio calmodulina dependiete

Receptor opioide mu de Catostomus commersoni (Catostomus

comersoni Mu Opioid Receptor)

DNA copia

Citomegalovirus

D-Phe-Cys-Tyr-D-Trp-Arg-Thr-Pen-Thr- $\mathrm{NH}_{2}$

D-Phe-Cys-Tyr-D-Trp-Orn-Thr-Pen-Thr- $\mathrm{NH}_{2}$

Tyr-D-Ala-Gly-Phe-D-Leu-NH ${ }_{2}$

$\left[\mathrm{D}-\mathrm{Ala}^{2}, \mathrm{~N}-\mathrm{MePhe}{ }^{4}, \mathrm{Gly}-\mathrm{ol}\right]-$ encefalina

Dietilpirocarbonato

Dulbecco's Modified Eagle's Medium

Dimetil sulfóxido

Dioctadecildoglicil-espermina

[D-Pen ${ }^{2}$, D-Pen $\left.{ }^{5}\right]$-Encefalina

Desintegraciones por minuto

$\left[\mathrm{D}-\mathrm{Ser}^{2}, \mathrm{Leu}^{5}, \mathrm{Thr}^{6}\right.$ ]-encefalina

Dosis efectiva media

Primer lazo extracelular

Segundo lazo extracelular

Tercer lazo extracelular

Ácido Etilen-diamino-tetracético

Etilcetociclazocina

Forward Scatter

Hormona folículo estimulante

Ácido $\gamma$ amino gutámico

Gliceraldehido 3 fosfato deshidrogenasa

Inwardly Rectifying $K+$ Channel

Media geométrica (Geomean)

Receptor acoplado a proteína G (G Protein Couple Receptor) 
GR89,696

GRK

h

HA

hDOR

HEK MT

HEK-293

HEPES

hKOR

hMOR

hn RNA

hORL

IASP

IBMX

ICI 174864

LIC1

LIC2

LIC3

IP3

IPTG

Kb

$\mathbf{K}_{\mathbf{d}}$

KDa

$\mathbf{K}_{\mathbf{i}}$

LH

MAPK

MCS

mDOR

medio LB

MEGY

$\min$

mKOR

mMOR

mORL

NalBZOH
(4-[(3,4 - diclorofenil)acetil] - 3 - (1 - pirrolidinilmetil $)$ - 1 - ácido piperazina carboxílico metil éster fumarato)

Kinasa de receptor acoplado a proteina $\mathrm{G}$ (G-protein coupled

Receptor Kinase)

Horas

Hemaglutinina

Receptor opioide delta de humano

HEK MOR Tagged

Células embrionarias de riñón humano (Human Embryonic Kidney)

Ácido 4-(2-hidroxietil)-1-piperazineetanosulfonico

Receptor opioide kappa de humano

Receptor opioide mu de humano (Human Mu Opioid Receptor)

RNA heterogeneo nuclear

Receptor similar a receptor opoiode de humano

La Asociación Internacional para el Estudio del Dolor

Isobutilmetilxantina

N.N-Diallyl-Tyr-Aib-Aib-Phe-Leu- $\mathrm{NH}_{2}$

Primer lazo intracelular

Segundo lazo intracelular

Primer lazo intracelular

Inositol-1,4,5-trifosfato

Isopropil-1-Tio- $\beta$-D-tiogalactopiranosido

Kilobases

Constante de disociación

Kilodalton

Constante de inhibición

Hormona luteinizante

Mitogen Activated Protein Kinase

Sitio de clonaje multiple (Multiple Cloning Site)

Receptor opioide delta de ratón

Luria-Bertoni

Met-encefalina-Gly-Tyr

Minutos

Receptor opioide kappa de ratón

Receptor opioide mu de ratón (Mouse Mu Opioid Receptor)

Receptor similar a receptor opoiode de ratón

Naloxona benzilhidrazona 
NCBI

NG108-15

Nor-BNI

NTB

NTI

O.D.

ORF

ORL

pb

PBS

PCR

PDYN

PENK

PKA

PKC

PLC

PL017

PNOC

POMC

rDOR

rKOR

rORL

rpm

RT

$\mathbf{S}$

SEM

SFK 10.047

SNC80

SSC

TBE

TE

THC

TIPP

TSH

U50,488
National Center for Biotechnology Information

Línea celular glioma-hibridoma murina

Nor binaltorfimina

Naltriben

Naltrindol

Densidad óptica (Optical Density)

Fase de lectura abierta (Open Reading Frame)

Similar a receptor opioide (Opioid Receptor Like)

Pares de bases

Buffer fosfato salino

Reacción en cadena de la polimerasa (Polymerase Chin Reaction)

Prodinorfina

Proencefalina

Proteína kinasa dependiente de AMPc

Proteína kinasa $\mathrm{C}$

Fosfolipasa C

$\left[\mathrm{NMePhe}^{3}, \mathrm{DPro}^{4}\right]$-morficeptina

Pronociceptina

Proopiomelanocortina

Receptor opioide delta de rata

Receptor opioide kappa de rata

Receptor similar a receptor opoiode de rata

Revoluciones por minuto

Retrotranscripción

Segundos

Error Estándar de la media

2'hidroxi-5,9-dimetil-2-alil-6,7-benzomorfano

(+)-4-[( $\alpha \mathrm{R})-\alpha-((2 \mathrm{~S} 5 \mathrm{R})-4-$ alil-2,5-Dimetil-1-piperazinil)-3-

metoxibenzil]-N,N-dietilbenzamida

Side Scatter

Tris-borato EDTA

Tris-EDTA

Tetrahidrocannabinol

H-Tyr-Tic-Phe-Phe-OH

Hormona estimulante del tiroides

(-)-(1S,2R)-cis-3,4-Dicloro-N-metil-N-[2-(1-pirrolidinil) ciclohexil]

benzenoacetamida 
U69,593

X-Gal

zfDOR1

zfDOR2

zfKOR

zfMOR

ZFOR1

ZFOR2

ZFOR3

ZFOR4

zfORL

zfPENK

zfPOMC

BFNA

$\beta$-MSH

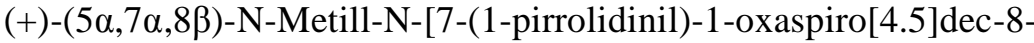

il]-benzenoacetamida

5-bromo-4-cloro-3-indolil- $\beta$-D-galactopiranosido

Receptor opioide delta 1 de pez cebra (Zebrafish Delta Opioid

Receptor 1)

Receptor opioide delta 2 de pez cebra (Zebrafish Delta Opioid

Receptor 2)

Receptor opioide kappa de pez cebra (Zebrafish Kappa Opioid Receptor)

Receptor opioide mu de pez cebra (Zebrafish Mu Opioid Receptor)

Receptor opioide delta 1 de pez cebra (Zebrafish Opioid Receptor 1)

Receptor opioide mu de pez cebra (Zebrafish Opioid Receptor 2)

Receptor opioide kappa de pez cebra (Zebrafish Opioid Receptor 3)

Receptor opioide delta 2 de pez cebra (Zebrafish Opioid Receptor 4)

Receptor semejante a receptor opioide de pez cebra (Zebrafish

Opioid Receptor Like)

Proencefalina del pez cebra

Proopiomelanocortina del pez cebra

$\beta$-funaltrexamina

Hormona melanocito estimulante 
Introducción 

Cada individuo aprende el significado de la palabra dolor a través de su experiencia personal; podemos decir que el dolor es un mecanismo de alarma mediante el cual un individuo reconoce un daño en la integridad física de su cuerpo. La Asociación Internacional para el Estudio del Dolor (IASP) lo define como “ una experiencia sensorial y emocional desagradable, asociada con un daño tisular real o potencial y que incluye una serie de conductas relacionadas con el dolor, visibles o audibles, que pueden ser modificadas por el aprendizaje" (León-Olea, 2001). La nocicepción está modulada por factores psicobiológicos y se puede percibir o no como dolor, dependiendo del entorno, ámbito cultural, hábitos familiares, etc. En este sentido, la alodinia se puede definir como presencia de dolor ante un estímulo que normalmente no desencadena dolor.

\subsection{Opioides, perspectiva histórica}

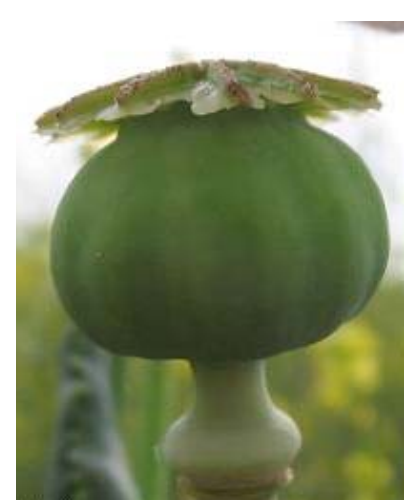

Figura 1: Fruto de la adormidera (Papaver sommiferum)
Intentar calmar el dolor ha sido y sigue siendo una de las preocupaciones más importantes en el mundo de la Medicina. Desde tiempos remotos se han empleado plantas para paliar el dolor. Entre éstas destaca el uso de productos derivados de la amapola (Papaver somniferum) o adormidera, siendo el más conocido el opio, también denominado meconium (Figura 1). Se sabe, por interpretación de datos arqueológicos, que los primeros cultivos de amapolas para su uso medicinal aparecen en la Baja Mesopotamia por los años 3400 
a.C., así los sumerios se referían a ella como "Hul Gil", la planta de la felicidad. De

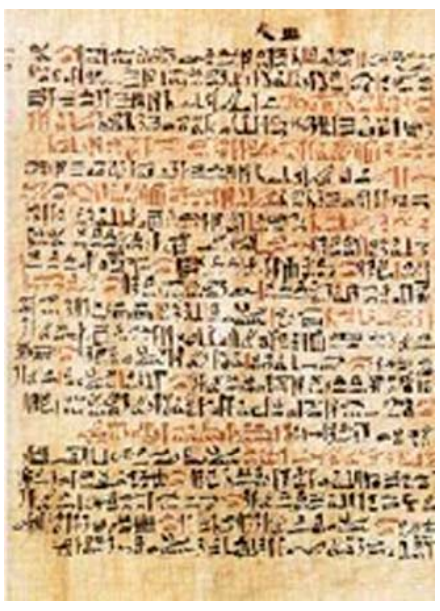

Figura 2: Fragmento del papiro de Ebers en el que se describen sustancias analgésicas esta zona de Oriente Medio su utilización se propagó hacia culturas de la Europa mediterránea y del resto de Asia. En el Antiguo Egipto se recogen datos de su uso medicinal. Se hace referencia en una gran cantidad de jeroglíficos al jugo que se extraía de las cabezas de las amapolas y se recomienda como analgésico y calmante. En el papiro de Ebers (Figura 2), el más antiguo de los tratados médicos conocidos, datado cerca del año 1500 a.C. en el antiguo Egipto, se explica uno de sus empleos reconocidos "evitar que los bebes griten fuerte". En el año

340 a.C., Hipócrates, padre de la medicina, le da el nombre actual; éste junto con sus discípulos, difundieron su uso en la Grecia Antigua, utilizándolo como analgésico, anestésico en cirugía e, incluso, para practicar la eutanasia a enfermos terminales. En este sentido, Plinio el Viejo (Cayo Plinio Cecilio Segundo) en su obra Naturalis historia comenta: "de los bienes que la naturaleza concedió al hombre ninguno hay mejor que una muerte a tiempo, y lo óptimo es que cada cual pueda dársela a sí mismo". Los médicos griegos también utilizaban pequeñas dosis de opio para preparar las zeriaka o triacas, antídotos para el envenenamiento que contenían venenos en dosis homeopáticas (como cicuta o acónito). Posteriormente, cuando Galeno confeccionó su Antidoto Magno, en el siglo II, la proporción de jugo de adormidera había crecido hasta un $40 \%$. Prácticamente todos los emperadores romanos usaban triacas a diario. Dioscórides en su libro Materia medica describe el opio como algo que quita totalmente el dolor, mitiga la tos, frena los reflujos estomacales y se aplica a quienes no pueden dormir. Además, gracias a él, y a otros 
escritores romanos, se sabe que era frecuente la adulteración del opio debido a que su demanda era muy grande (Figura 3). En el año 312 había censadas 793 tiendas dedicadas a vender opio en Roma. Sin embargo, pese a su extenso uso no hay referencias sobre los problemas que su uso conlleva; a los usuarios habituales no se los considera ni enfermos, ni marginados sociales. De ahí que en latín no haya una expresión equivalente a opioinómano, si bien ya había al menos una docena de

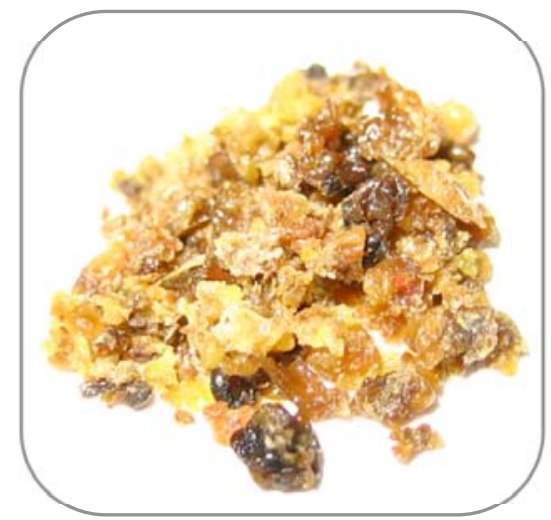

Figura 3: Opio puro equivalentes a alcohólico. Esta planta llegó desde la cuenca mediterránea portada por Alejandro Magno hasta Asia. En la medicina árabe, Albucasim, médico del califa Abderramán, usaba cilantro y opio para dolores intensos, y Avicena propugnaba su uso en el Islam del siglo X. Tras la Edad Media, en la cual la farmacopea cayó en desuso, Paracelso promovió el uso de una bebida que contenía opio a la que denominó láudano (vino blanco, azafrán, clavo, canela y otras sustancias además del opio), calificándola de "piedra de la inmortalidad" y cuyo uso se extendió a lo largo de toda Europa central en el siglo XVI. Ya en el siglo XVII destacan las figuras de Thomas Sydenham en Inglaterra, que usaba vino de Málaga, y Van Helmont en Holanda; ambos consideraban al opio como una panacea universal para todos los males. Se usaba comúnmente para reducir cualquier tipo de dolor, desde el dolor provocado por la salida de los dientes en los niños a los típicos dolores producidos por el cáncer y otras enfermedades

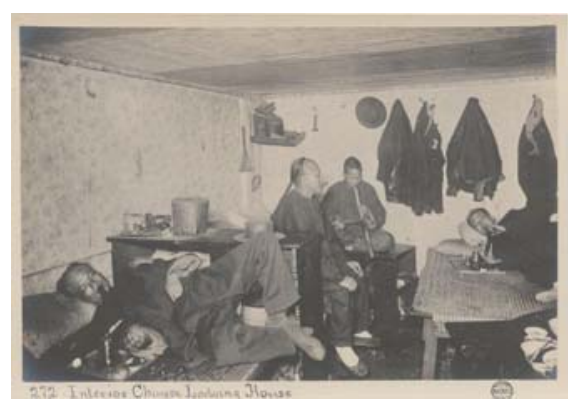

Figura 4: Fumadero de opio en una casa de huéspedes china en San Francisco, California. (1890)

terminales; para adormecer, para la ansiedad, para el tratamiento de la diarrea 
(prescripción que aún se sigue utilizando en algunos casos) y para eliminar la tos en todo tipo de procesos, desde una simple gripe a una tuberculosis.

El Opio es, junto con los productos derivados de la fermentación alcohólica, probablemente una de las primeras sustancias con características psicoactivas que el hombre empleó con fines lúdicos (Figura 4), además de fines médicos; así, junto a su uso se desarrolló paralelamente su abuso. No existen referencias históricas que mencionen que el opio produce adicción hasta el siglo XVI, cuando se describen los primeros casos de dependencia física y psíquica debidos al uso de este agente. En el siglo XIX existía un definido sistema comercial alrededor del opio, que desencadenó la denominada Guerra del Opio entre China e Inglaterra, ya que el abuso de opio en

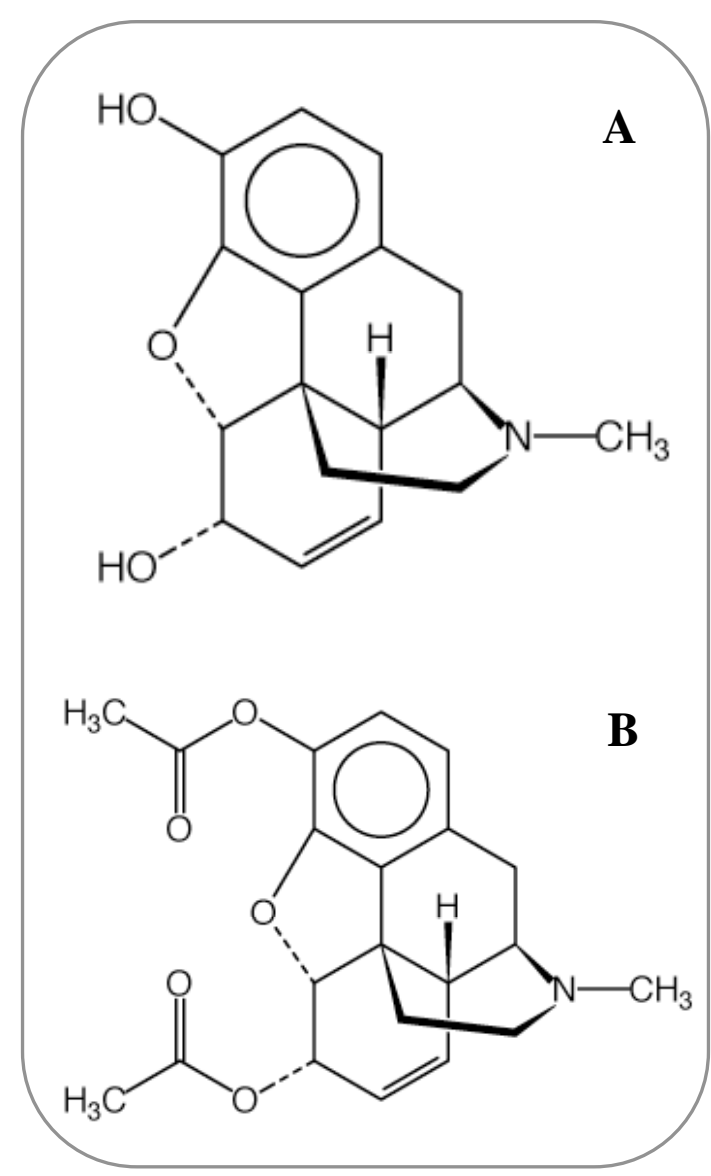

Figura 5: A. Estructura de la morfina. B. Estructura de la heroína (diacetilmorfina).
China se había convertido en un grave problema, y en Inglaterra era común su uso para el dolor de muelas, los cólicos, e incluso se daba a casi todos los bebés y niños pequeños para mantenerlos tranquilos.

En 1806, un farmacéutico alemán, Friedrich W. A. Sertürner, aisló por primera vez el principal componente del opio, una base alcalina de color blanco amarillento a la que denominó morfina en honor a Morfeo, dios griego de los sueños. Debemos destacar que la morfina es la primera sustancia química pura aislada e identificada como el 
principio activo de un producto natural (Figura 5A). La morfina representa aproximadamente el $15 \%$ del peso total del opio. El opio, además de morfina, contiene hasta un $25 \%$ de su peso en alcaloides (Figura 6). Con el tiempo se llegaron a aislar otros componentes del opio como la codeína o metilmorfina $(0.5 \%$ en peso del opio), importante sustancia con propiedades antitusígenas y ligeramente adictivas; tebaína que posee efectos convulsivantes pero no analgésicos (1\%); papaverina con ligeras propiedades relajantes musculares $(1 \%)$; y noscapina también con propiedades antitusígenas (10\%).

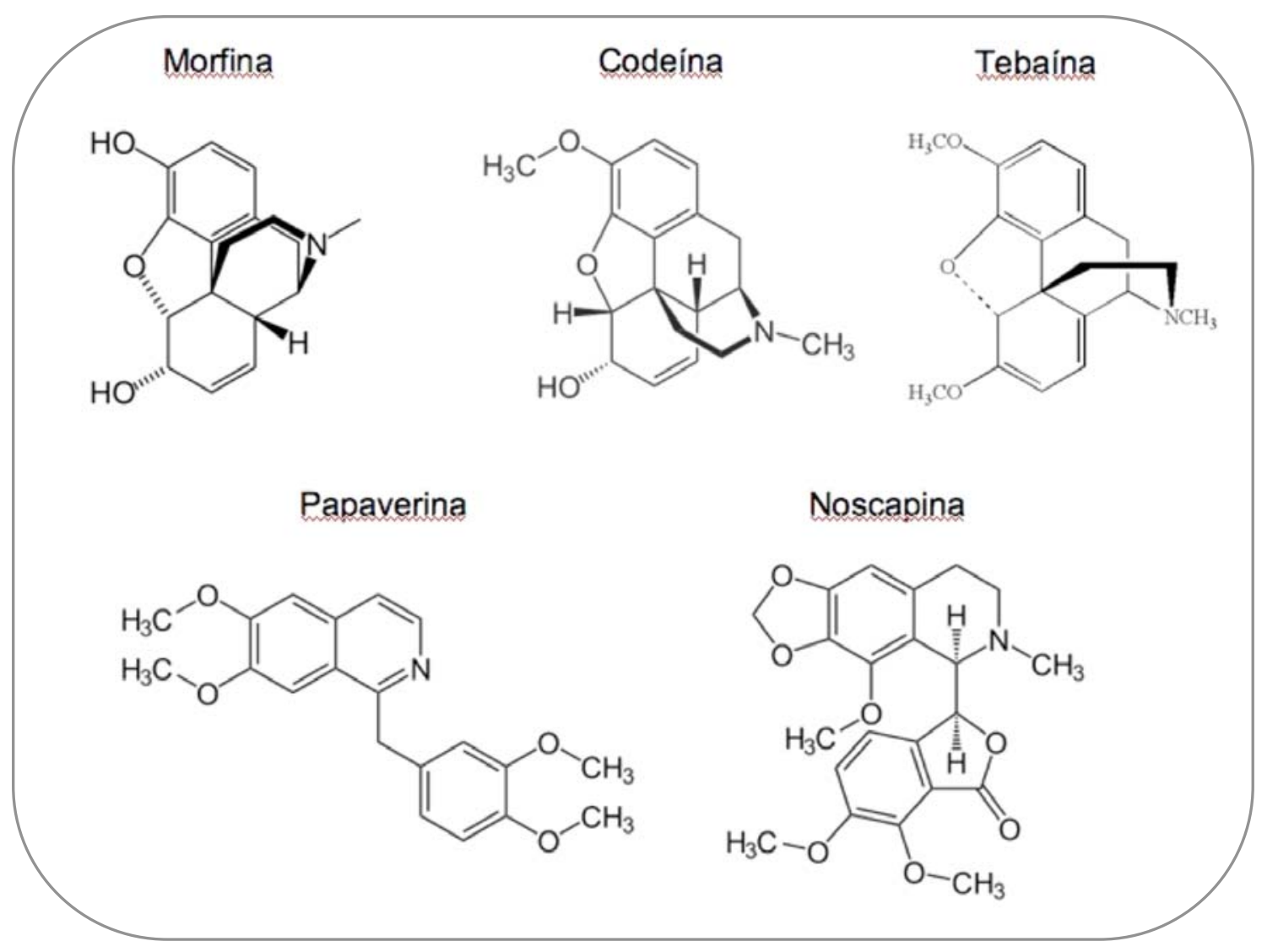

Figura 6: Principales alcaloides presentes en el opio: morfina, codeína, tebaína, papaverina y noscapina.

La morfina fue incorporándose a una gran variedad de remedios al alcance del público para el tratamiento del dolor, y aún hoy en día es el analgésico de elección en casos de dolor muy intenso y como referente para la evaluación de nuevos productos 


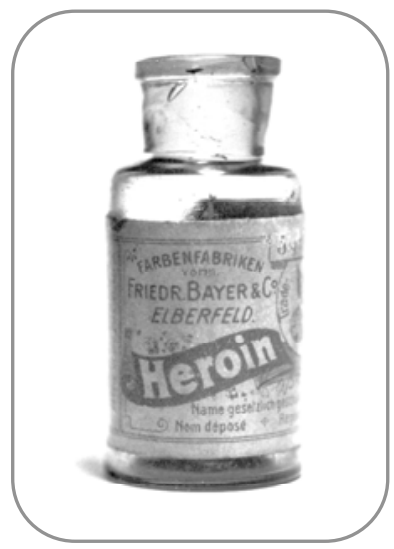

Figura 7: Envase de la heroína comercializada por Bayer. En 1899 Bayer producía una tonelada de heroína al año. analgésicos. Con la invención de la jeringuilla hipodérmica, la difusión del uso de la morfina aumentó considerablemente convirtiéndose en droga medicinal de uso preponderante. Al observar que la morfina era tan adictiva como el opio y dado que ya existía una preocupación por sus efectos indeseables, se procedió a la búsqueda de nuevos compuestos que carecieran de estas características; así, un químico inglés C.R. Wright en 1874 sintetizó la heroína (Figura 5B), cuando accidentalmente hirvió morfina junto con anhídrido acético durante varias horas. Este derivado diacetilado llega con más facilidad al sistema nervioso. Sin embargo no fue éste, sino Heinrich Dreser quien vio su potencial comercial. En 1897 la empresa farmacéutica Bayer sintetiza la heroína y pronto es comercializada siendo anunciada como no adictiva (Snyder, 1996) (Figura 7). No fue hasta principios del siglo XX cuando se advirtió que la heroína poseía propiedades tan adictivas como la morfina. (Para una revisión más completa de los aspectos históricos del uso del opio y la morfina ver: Brownstein, 1993; Escohotado, 1992; Snyder, 1996.

\subsection{Mecanismos de modulación del dolor por el sistema opioide}

La percepción de los estímulos dolorosos, de tipo mecánico, térmico o químico, así como la respuesta a inflamación aguda o crónica o lesiones en los nervios, implica la participación de estructuras neuronales, desde los terminales periféricos hasta las regiones somatosensoriales de la corteza cerebral, cada uno de los 
cuales participa en mecanismos modulatorios muy diversos, y es también objeto de otros sistemas reguladores (Zieglgänsberger y Tölk, 1993).

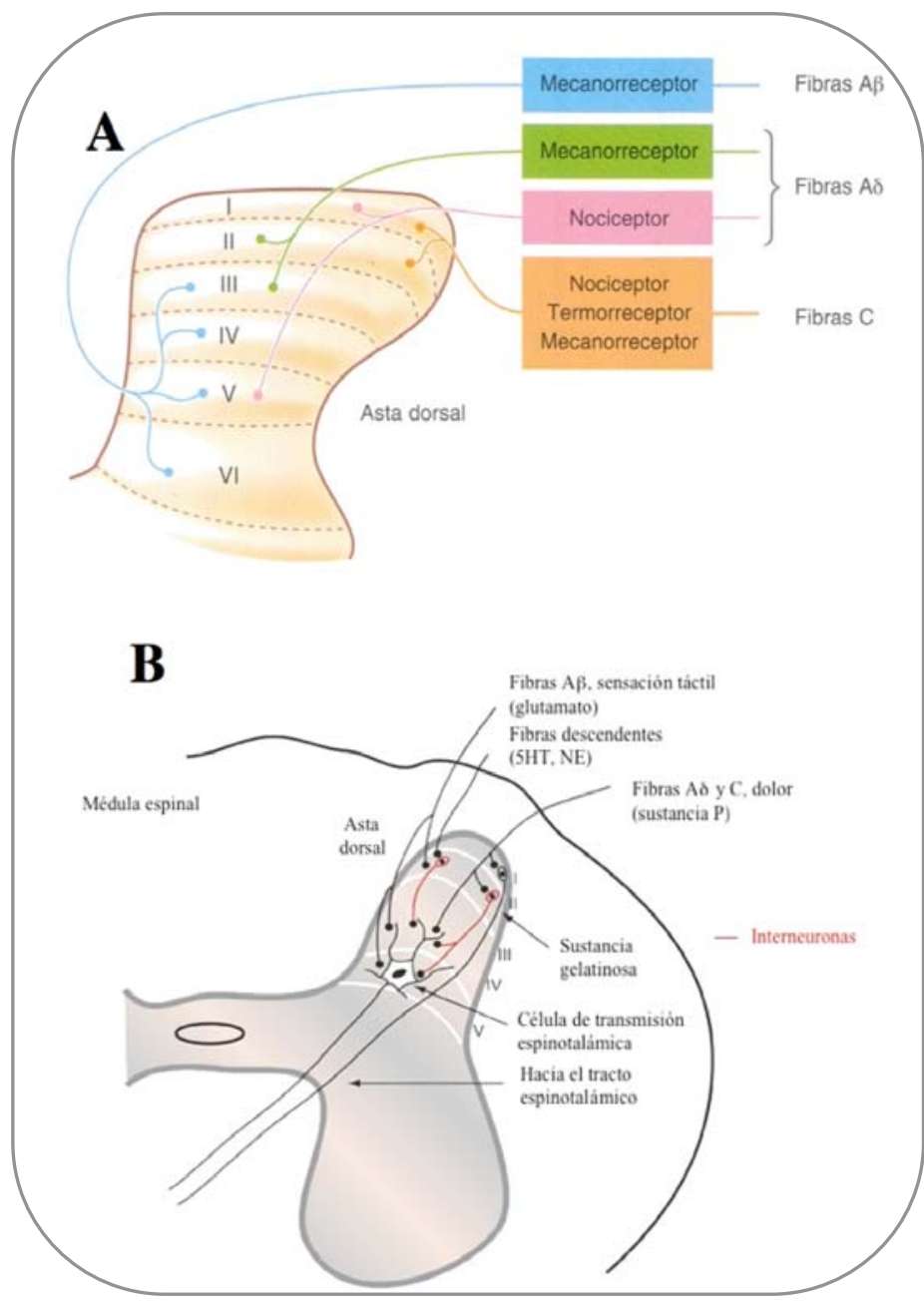

Figura 8: Esquema que representa las aferencias hasta el asta dorsal de la médula espinal en distintos tipos de receptores somatosensoriales. B: Regulación de la vía nociceptina por la vía descendente (5HT. Serotonina; NE. Norepinefrina).

La sensación dolorosa se transmite a través del sistema aferente desde las terminaciones de fibras nerviosas del tipo A- $\delta$ y C hasta las astas dorsales de la medula espinal (Figura 8A). Posteriormente la información es transmitida por cinco vías ascendentes, la vía espinotalámica (neo y paleo-espinotalámica), espino-reticular, espino-mesencefálica, cérvicotalámica y espino-hipotalámica (Figura 9). Estas vías proyectan a diversas regiones del tronco del encéfalo y diencéfalo incluyendo el tálamo, sustancia gris periacueductal, formación reticular parabraquial y núcleos de la porción rostroventral del bulbo raquídeo. Desde el tálamo parten proyecciones hacia distintas áreas, como el área sensitiva secundaria parietal, el lóbulo frontal, zonas del lóbulo temporal, el sistema límbico o el hipotálamo (Willis y Westlund, 1997, Bolay y Moskowitz, 2002). El sistema eferente, que controla la transmisión de la información nociceptiva tiene su origen en la corteza, mesencéfalo y bulbo raquídeo, e incluye estructuras como la sustancia gris periacueductal, locus 
coeruleus, subcoeruleus, núcleos de Kólliker-Fuse, núcleo magno del rafe y varios núcleos de la formación reticular bulbar (Willis y Westlund, 1997).

Los opioides actúan tanto sobre el sistema aferente que lleva la información nociceptiva como sobre el sistema eferente que lo controla, tanto a nivel supraespinal como en la propia médula espinal. Por una parte, los opioides activan las conexiones excitatorias entre la sustancia gris periacueductal y del núcleo reticular paragigantocelular, proyectando a la porción rostroventral del bulbo raquídeo, donde se localizan las neuronas del núcleo magno del rafe. Las neuronas del rafe, ricas en péptidos opioides, conectan a su vez con las neuronas nociceptivas en las láminas I, II, V, VI y VII de las astas dorsales de la médula espinal, a las que inhiben (Figura 8B)(Basbaum y Fields, 1984).

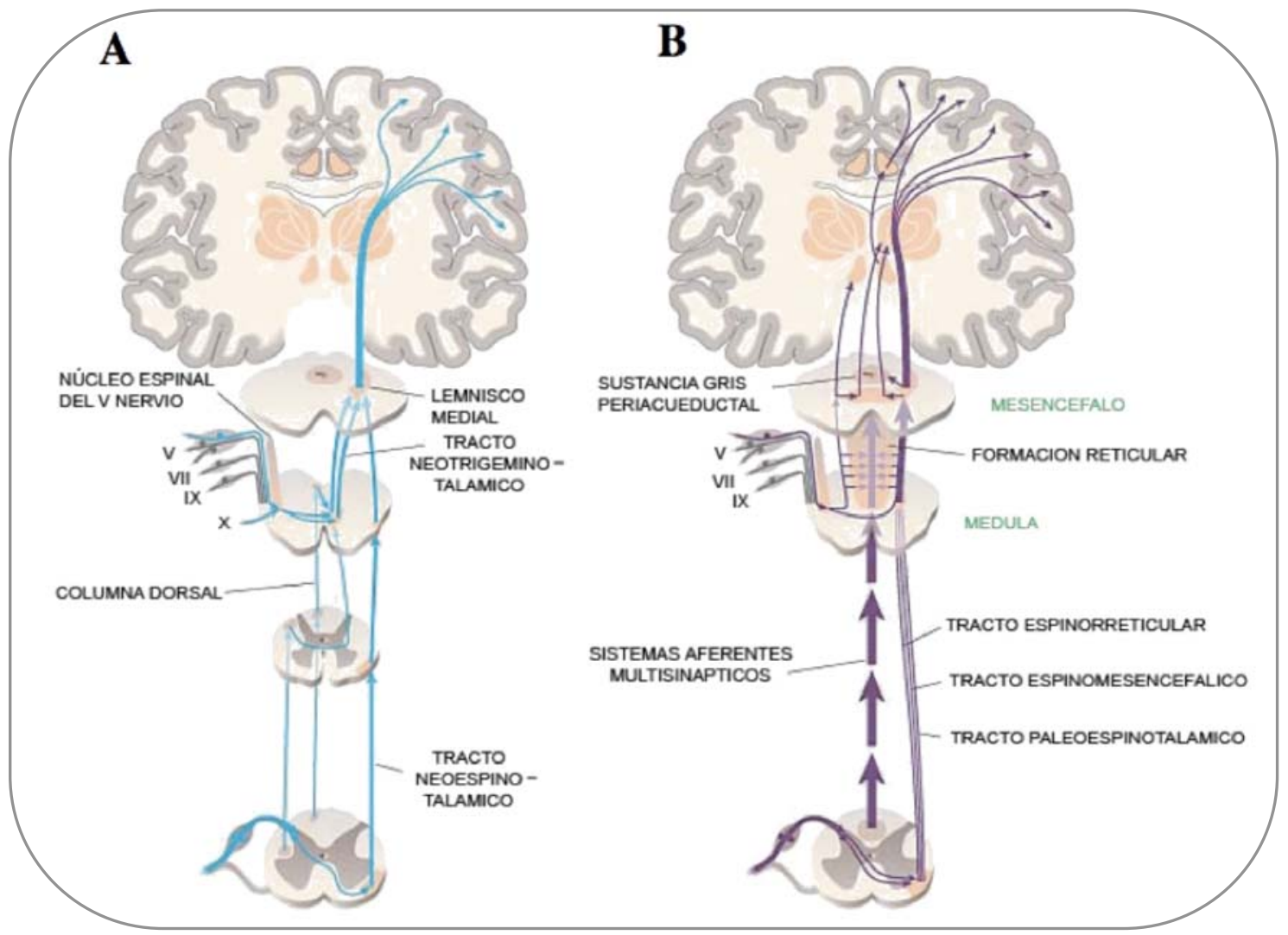

Figura 9: En los dibujos se representan las vías ascendentes de la información nociceptiva A: vía neoespinotalámica B: vía paleoespinotalámica, espinorreticular y espinomesencefálica 
Los opioides también actúan a nivel espinal, ya que existe una acción directa sobre el asta dorsal y las terminaciones periféricas de las neuronas aferentes nociceptivas, inhibiendo la liberación de sustancia P (Ossipov y cols., 2004).

El mecanismo de acción de los opioides en la parte rostroventral del bulbo raquídeo se basa en la existencia de dos clases de neuronas muy importantes para la transmisión del dolor. Estas células se denominan ON y OFF; las primeras van a facilitar la transmisión de la información nociceptiva y las sustancias opiáceas impiden su activación; las segundas inhiben la transmisión del impulso doloroso y son activadas indirectamente por las sustancias opiáceas mediante la inhibición de un mecanismo inhibitorio que es ejercido sobre ellas por interneuronas que contienen GABA y que son asimilables a las células ON (Fields y cols., 1991).

También es importante que los opioides actuan a nivel límbico y cortical no sólo reduciendo la sensibilidad al estímulo doloroso, sino también atenuando la percepción del dolor y el tono desagradable o angustioso del mismo. En algunos casos, el dolor es sustituido incluso por una sensación placentera, como la que acompaña a la administración de opiáceos (Flórez, 1992).

\subsection{Otros efectos fisiológicos de las sustancias opiáceas}

Además de los efectos analgésicos que poseen las sustancias opiáceas que las hacen importantes en el tratamiento del dolor, se han demostrado otro tipo de efectos en distintos tejidos. Uno de los primeros, que ya se conocía desde la antigüedad, es la actividad antidiarreica que presentan los opiáceos como resultado de la reducción de 
la motilidad y secreción gastrointestinal. También se ha observado aumento en la presión de las vías biliares con hipertonía del esfínter de Odi y con frecuencia también producen retención urinaria (Pasternak, 1988).

Las sustancias opiáceas también ocasionan depresión respiratoria, afectando más a la frecuencia que a la amplitud, y a dosis altas son capaces de producir ritmos anormales y apnea, provocando una reducción de la sensibilidad del centro respiratorio al $\mathrm{CO}_{2}$. Por otra parte son capaces de deprimir el reflejo de la tos. Los opiáceos también van a tener efectos sobre el sistema cardiovascular produciendo bradicardia e hipotensión por vasodilatación tanto arterial como venosa. Otros efectos derivados de la administración de sustancias opiáceas son la hipotermia de origen hipotalámico, miosis, hipertonía de origen central e inducción de nauseas y vómitos (Pasternak, 1988). En el sistema neuroendocrino los opiáceos modifican la secreción hipofisaria por actuar tanto sobre el hipotálamo como sobre la hipófisis. Estimulan la secreción de la hormona adrenocorticotropa (ACTH), somatostatina, prolactina, hormona estimulante de los melanocitos $\beta(\beta-\mathrm{MSH})$ y hormonas antidiuréticas; también inhiben la secreción de la hormona estimulante del tiroides (TSH), hormona luteinizante (LH) y folículo estimulante (FSH) (Mansour y cols., 1995a).

Por último, se ha observado que la administración crónica de opiáceos provoca depresión del sistema inmune afectando a varios de los tipos celulares que lo componen (Chao y cols., 1997; Eisenstein y cols., 1998; McCarthy y cols., 2001). 
La adicción se puede definir como una enfermedad compleja que se caracteriza por una compulsiva, a veces incontrolable, ansia o deseo irresistible de acceder a una sustancia para administrársela (craving) y la búsqueda compulsiva (seeking) y el uso que persiste incluso a pesar de sus, en ocasiones, graves efectos perjudiciales y con posibles recaídas incluso tras largos periodos de abstinencia.

\subsubsection{Tolerancia}

La tolerancia se define como una disminución o pérdida en el efecto de una droga, como consecuencia de su administración a lo largo del tiempo, de forma regular, ocasionando que se requiera más cada vez para producir el mismo efecto. De esta forma adictos que han desarrollado tolerancia hacia una droga deben administrarse dosis mucho mayores, que en el caso de los opiáceos parece no alcanzar un máximo. Sirva de ejemplo la experiencia referida en Inglaterra donde se han usado dosis 100 veces mayores que la dosis psicoactiva de heroína en determinados pacientes, lo cual también es un procedimiento estándar en los programas de metadona.

El problema no se soluciona simplemente permitiendo a los adictos el uso de cocaína o heroína; por ejemplo, disponer de la cantidad que quieran de dichas drogas, ya que incluso en estos casos acaban apareciendo estados de ánimo negativos, con una irritabilidad incrementada, hostilidad y paranoia. 
La manifestación contraria a la tolerancia es la sensibilización o tolerancia reversa, en la que una dosis constante de droga produce efectos cada vez mayores.

\subsubsection{Dependencia}

Acompañando al proceso de tolerancia también se desarrolla un estado en el que el cese de la utilización de la droga produce el síndrome de abstinencia que es automáticamente bloqueado por la administración de una dosis de la misma droga. Ese estado se denomina dependencia. La dependencia no es un efecto de la droga en su sentido normal, ya que sólo se observa cuando se priva de dicha droga. La dependencia, como la tolerancia, es una consecuencia de la adicción, sin embargo también la dirige.

Dentro de las drogas de abuso más consumidas en nuestra sociedad, caben destacar los agentes opiáceos, que actúan a través del sistema opioide; el tetrahidrocannabinol (THC) en sus diversas formas de consumo, que actúa sobre el sistema endocannabinoide; y la cocaína y otros estimulantes como las anfetaminas, que llevan a cabo su acción a través del sistema dopaminérgico (Self y Nestler, 1995). Los opiáceos, entre los que destacan la morfina y la heroína, son de particular interés, pues su diana fisiológica, el receptor opioide, es el componente más importante del sistema de analgesia endógena al inhibir la transmisión nociceptiva tanto a nivel central como periférico (Besson, 1999). 
Muchos compuestos, como neurotransmisores, hormonas, etc. actúan selectivamente sobre determinados sitios de reconocimiento, por lo que la alta especificidad y elevada potencia de los opioides sugirió la presencia de un sitio de unión específico en el sistema nervioso, a través del cual las sustancias opiáceas ejercerían su efecto. A ese sitio se lo denominó receptor opioide. Los primeros intentos para demostrar la existencia de este receptor específico fracasaron debido a su relativa escasez en los tejidos y la carencia de compuestos agonistas que pudieran ser marcados con suficiente radioactividad de forma que se permitiera distinguir entre la unión del compuesto y el ruido de fondo (Goldstein y cols., 1971). La demostración definitiva de la existencia del receptor opioide, es decir la existencia de sitios de unión específicos, estéreo-selectivos y saturables para sustancias opioides en el sistema nervioso de mamíferos, se logró simultáneamente en tres laboratorios utilizando ligandos marcados radiactivamente con una alta actividad específica que se podían usar a bajas concentraciones (Pert y Zinder, 1973; Simon y cols., 1973; Terenius, 1973). Asimismo, se observó que estos sitios de unión no presentaban una distribución homogénea dentro del sistema nervioso, concentrándose su localización en amígdala, sustancia gris periacueductal, hipotálamo, tálamo y núcleo caudado (Kuhar y cols., 1973).

La diferente actividad analgésica de los diversos compuestos opioides y la falta de tolerancia cruzada entre ellos; es decir, un compuesto dado no es capaz de suprimir el síndrome de abstinencia inducido en un animal habituado por otro distinto, hizo pensar en la posible existencia de más de un tipo de receptor opioide (Martin y 
cols., 1976). Inicialmente se definieron tres tipos de receptores opioides con propiedades farmacológicas claramente diferenciadas, que se denominaron en función de la existencia de un compuesto con actividad definida sobre cada uno de ellos: receptor mu, por la morfina; receptor kappa, por la ketociclazocina; y receptor sigma, por SKF 10047 (2’hidroxi-5,9-dimetil-2-alil-6,7-benzomorfano), si bien este último no se considera hoy en día como un receptor opioide, en parte debido a que su actividad no es bloqueada por el antagonista naloxona, como ocurre con los demás receptores opioides (revisado en Snyder y Pasternak, 2003). Un tercer tipo de receptor opioide, que se denominó delta, se descubrió al analizar la acción de las encefalinas en el vaso deferente de ratón (Lord y cols., 1977).

La idea de buscar distintos tipos y posteriormente subtipos farmacológicos de receptores opioides pretendía diferenciar el receptor que mediara las acciones analgésicas de aquel responsable de las propiedades adictivas de los opiáceos. Sin embargo, no fue hasta la clonación y caracterización de los receptores opioides cuando se comprobó que esas dos acciones están íntimamente relacionadas.

\subsection{Clonación de los receptores opioides}

La identificación de tipos y subtipos farmacológicos precedió a la clonación de los genes que codifican los receptores opioides y no se sabía si éstos estaban codificados por uno o varios genes. Hasta la fecha se conoce la existencia de cuatro genes que codifican los receptores opioides: delta, mu, kappa y ORL (de Opioid Receptor Like). A pesar de la existencia de únicamente 4 genes se han identificado múltiples fenotipos farmacológicos, por lo que actualmente se mantiene la teoría de 
que el resto de los subtipos se explicarían por productos de procesamiento alternativo, modificaciones postraduccionales, distinta localización tisular de los receptores y fenómenos de homo- y/o heterodimerización e interacción diferencial con distintas proteínas intracelulares como las proteínas $\mathrm{G}$.

El primer receptor opioide clonado de forma simultanea, por dos grupos independientes, fue el receptor delta de rata y a este hecho le siguió la clonación del receptor en distintos organismos, y la clonación del resto de receptores (Tabla 1).

\begin{tabular}{|c|c|c|}
\hline Receptor & Especie & Publicación \\
\hline \multirow{5}{*}{ delta } & ratón & Evans y cols., 1992; Kieffer y cols., 1992 \\
\hline & rata & Fukuda y cols., 1993 \\
\hline & humano & Knapp y cols., 1994 \\
\hline & Rana pipiens & Stevens, 2004 \\
\hline & pez cebra & $\begin{array}{c}\text { Barrallo y cols., 1998a y b; Pineal- } \\
\text { Seoane y cols., } 2006\end{array}$ \\
\hline \multirow{8}{*}{ mu } & rata & $\begin{array}{c}\text { Fukuda y cols., 1993; Wang y cols., 1993; } \\
\text { Thompson y cols., } 1993\end{array}$ \\
\hline & ratón & Min y cols., 1994 \\
\hline & humano & Wang y cols., 1994a \\
\hline & Rana pipiens & Stevens, 2004 \\
\hline & \begin{tabular}{|l|} 
Catostomus \\
commersoni \\
\end{tabular} & Darlison y cols., 1997 \\
\hline & Bovino & Onoprishvili y cols., 1999 \\
\hline & Porcino & Pampusch y cols., 1998 \\
\hline & pez cebra & Barallo y cols., 2000 \\
\hline \multirow{5}{*}{ kappa } & ratón & Yasuda y cols., 1993 \\
\hline & rata & Nishi y cols., 1993 \\
\hline & humano & Simonin y cols., 1995 \\
\hline & rana pipiens & Stevens, 2004 \\
\hline & pez cebra & Alvar y cols., 2006 \\
\hline \multirow{4}{*}{ ORL } & ratón & Nishi y cols., 1994 \\
\hline & rata & Wang y cols., 1994b \\
\hline & Humano & Mollereau y cols., 1994 \\
\hline & pez cebra & Rivas boyero, Tesis Doctoral 2003 \\
\hline
\end{tabular}

Tabla 1: Referencias de la clonación de los primeros receptores opioides en las principales especies utilizadas 
El receptor delta que fue clonado utilizando una genoteca de expresión de la línea celular glioma-hibridoma NG108-15 murina, que expresa altos niveles del receptor delta y que carece de receptores de tipo mu y kappa, mostró características de unión a ligandos selectivos delta y se ha asociado con el subtipo farmacológico delta 1 .

Tras la clonación del primer receptor opioide se pudieron generar oligonucleótidos degenerados que permitieron la clonación del receptor mu, el receptor morfínico que resultaría corresponder al subtipo farmacológico $\mathrm{mu}_{1}$. El receptor kappa se encontró por casualidad cuando se intentaba clonar el receptor de somatostatina de ratón. El análisis farmacológico de los receptores de mamífero expresados en sistemas heterólogos indicó que el receptor clonado se comporta como subtipo kappa ${ }_{1}$

El receptor ORL se clonó en 1994. Al realizar ensayos farmacológicos con el receptor ORL de mamíferos se comprobó que los compuestos opioides clásicos presentaban muy baja afinidad por este receptor. Como no se conocía el ligando de este receptor se le denominó "receptor huérfano" u ORL. Posteriormente se identifico el ligando endógeno, un péptido de 17 aminoácidos muy parecido a la dinorfina A, y que se denominó nociceptina u orfanina FQ (Meunier y cols., 1995; Reinscheid y cols., 1995).

\subsection{Caracterización molecular de los receptores opioides}

Tras la clonación de los distintos tipos de receptores opioides se han podido realizar comparaciones entre sus secuencias y se ha comprobado que presentan una 
alta homología entre ellos. Estos receptores pertenecen a la superfamilia de receptores con siete dominios transmembrana y que se acoplan a proteínas $\mathrm{G}$ heterotriméricas, también denominados GPCR ( $G$ Protein Couple Receptor). La existencia de los siete dominios transmembrana genera tanto en el lado interno de la membrana como en el externo una serie de lazos que van a ser fundamentales para su funcionamiento. Además en el lado externo de la membrana se localiza el extremo amino terminal y en el interno el extremo carboxilo terminal. Los tres lazos que quedan hacia el exterior estan implicados en la selectividad del receptor, mientras que los internos serán los encargados de la transducción de la señal (Reisine, 1995) (Figura 10). Esta estructura se comparte con un gran número de receptores de neurotransmisores, tales como la sustancia P, neuropéptido Y, somatostatina, etc. (Uhl y cols., 1994).

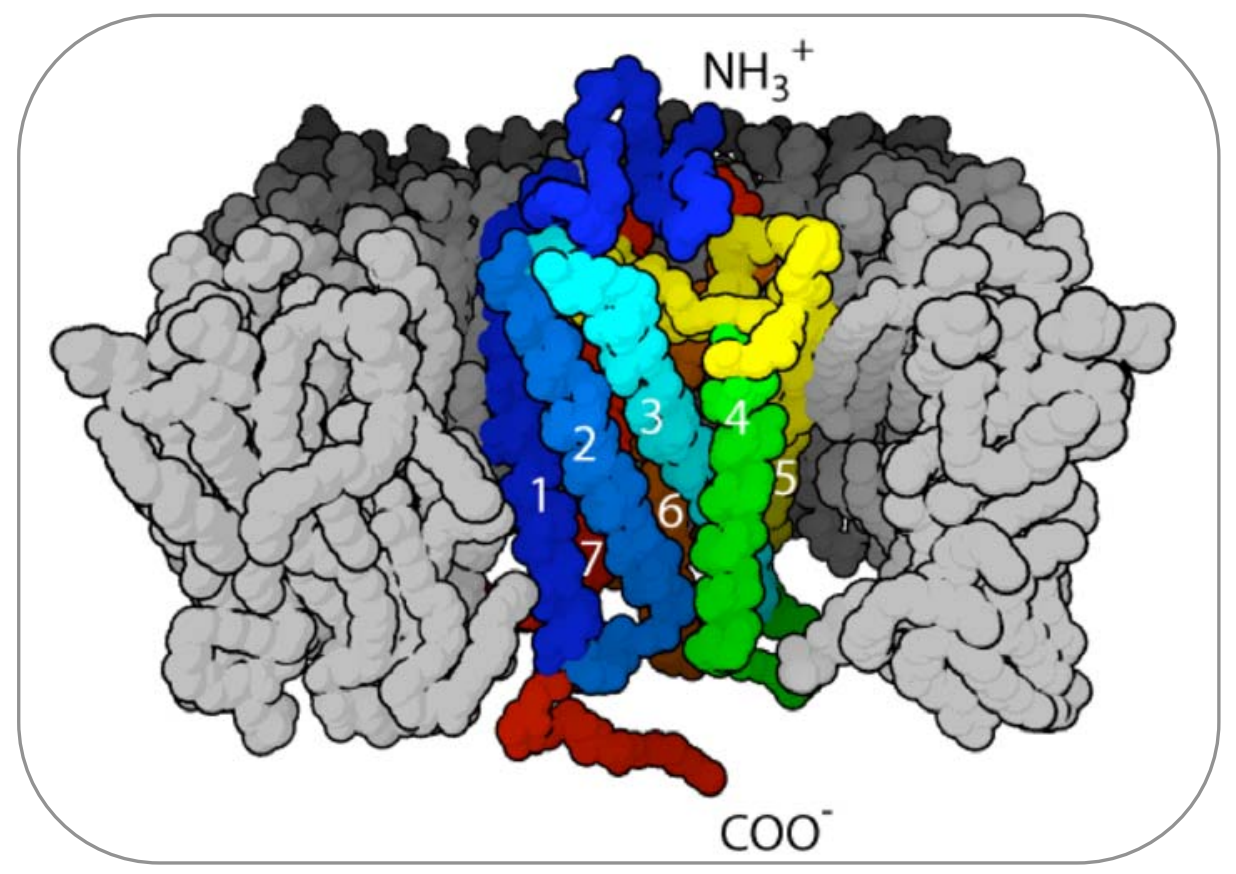

Figura 10: Esquema de la estructura general de un receptor opioide, miembro de la superfamilia de receptores acoplados a proteínas G (GPCRs). Se puede observar como el receptor se encuentra inmerso en la bicapa lipídica, con su extremo amino terminal hacia el exterior celular y el carboxilo hacia el interior. También se puede apreciar la disposición de las hélices transmembrana, muy importantes para su funcionamiento, así como los lazos intra y extracelulares. 
En mamíferos este tipo de receptores presenta una serie de modificaciones postraduccionales tales como $\mathrm{N}$-glicosilaciones en residuos de asparragina en el extremo amino terminal (cinco sitios en el receptor de tipo mu y dos en los receptores kappa y delta). También nos encontramos con la presencia de un puente disulfuro entre residuos de cisteína en el segundo y tercer lazo extracelular, permitiendo una estabilización de la estructura tridimensional de la proteína. En el extremo carboxilo terminal así como en el tercer lazo intracelular existen secuencias consenso de fosforilación en residuos de serina y treonina, los cuales intervendrían en la regulación de la actividad del receptor. También hay un resto de cisteína en el extremo carboxilo terminal susceptible de palmitoilación que formaría un cuarto lazo intracelular tal y como ocurre en otros receptores pertenecientes a la misma superfamilia de receptores que se acoplan a proteínas G.

Cuando se comparan las secuencias de estos receptores podemos observar que la mayor homología se encuentra en los segmentos transmembrana, seguidos por los lazos intracelulares segundo y tercero. Este alto grado de homología sugiere que los mecanismos de transducción de la señal son muy similares en todos los receptores opioides. Por el contrario los dominios de menor homología son los lazos extracelulares y los extremos amino y carboxilo terminal (Satoh y Minami, 1995).

Una de las teorías formuladas para explicar la unión diferencial de ligandos opioides al receptor postula la existencia de un bolsillo de unión formado por parte de las hélices transmembrana, el cual sería común a todos los receptores. La selectividad vendría dada por un mecanismo de exclusión al interactuar los ligandos con los lazos extracelulares, de forma que éstos actuarían como una barrera selectiva, favoreciendo 
o impidiendo el acceso de los ligandos al bolsillo de unión. De esta manera se podría aplicar el concepto de "mensaje-dirección" a los ligandos opioides: el "mensaje" estaría constituido por aquellos grupos químicos que interaccionan con el bolsillo de unión, mientras que la "dirección" intervendría en el proceso de discriminación por los lazos extracelulares. Esta teoría explicaría por qué los ligandos no selectivos son relativamente insensibles a mutaciones puntuales, al contrario que los ligandos altamente selectivos. En el caso de los antagonistas, se cree que se introducen más profundamente en el bolsillo de unión, impidiendo el movimiento de las hélices transmembrana 3 y 7, con lo que se impide a su vez que el receptor adopte la conformación activa (Pogozheva y cols., 1998) (Figura 11).

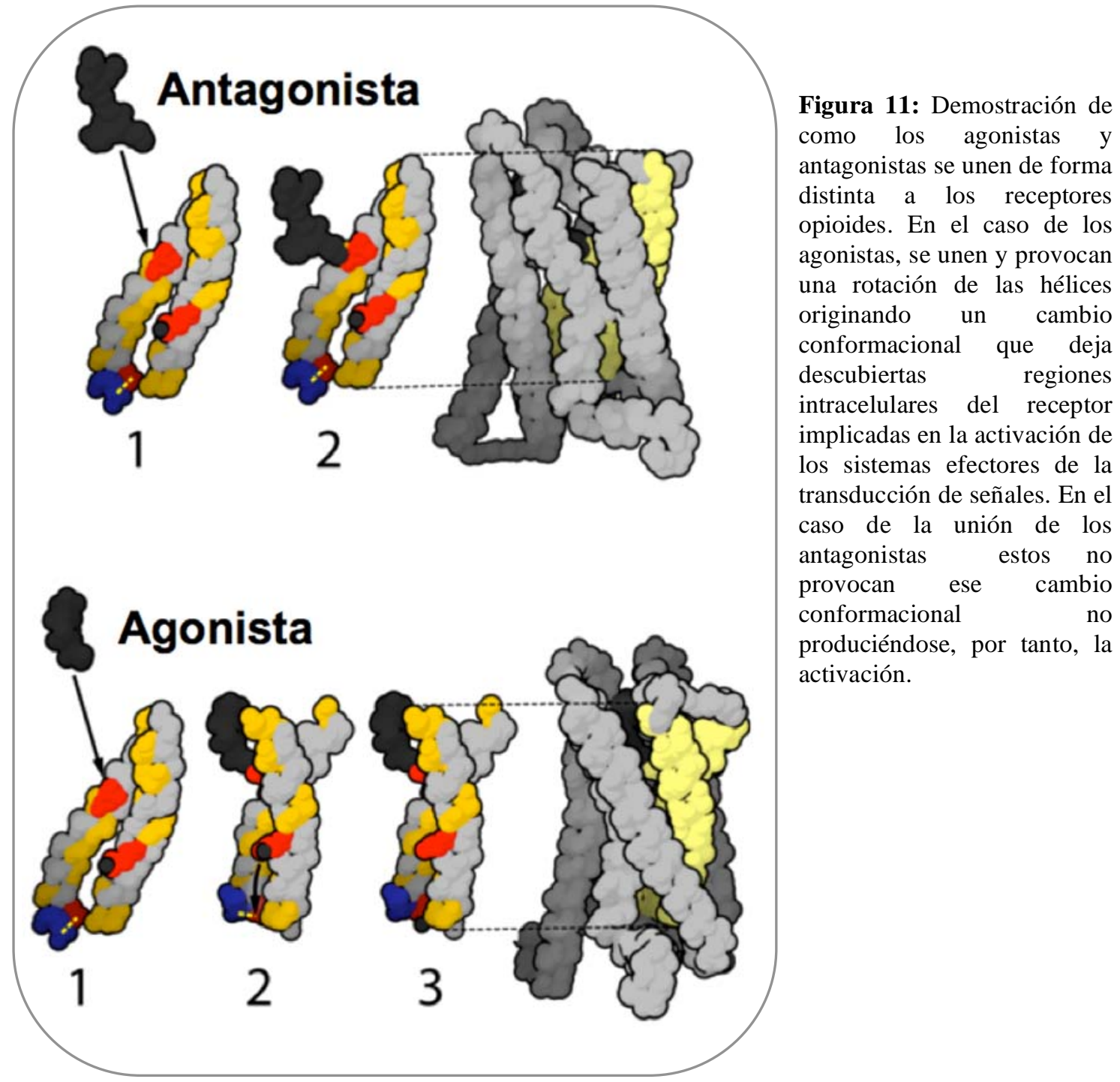


Este teoría fue formulada inicialmente por Metzger y Ferguson en 1995, y ha sido avalada posteriormente por los resultados de otros autores (Befort y cols., 1996; Pepin y cols., 1997).

\subsection{Los péptidos opioides}

En 1975 se aisló del cerebro de cerdo un factor que inhibía tanto la liberación de acetilcolina en los nervios que inervan el intestino delgado (Kosterlitz y Waterfield, 1975) como las contracciones del vaso deferente de ratón (Hughes, 1975), siendo ambos efectos bloqueados por la naloxona. Teniendo en cuenta que la naloxona actúa de forma selectiva sobre los receptores opioides, se llegó a la conclusión de que ese factor debía de ser su ligando endógeno. La posterior caracterización molecular de dicho factor determinó que se trataba de dos pentapéptidos cuya secuencia únicamente difería en el aminoácido carboxilo terminal, metionina o leucina, por lo que se denominaron Met-encefalina y Leu-encefalina respectivamente (Hughes y cols., 1975). El estudio de la estructura de estos dos péptidos demostró que la conformación tridimensional de la tirosina en posición amino terminal (Tyr - Gly - Gly - Phe - Met / Leu) es parecida a la de la morfina (Figura 12): un anillo aromático hidroxilado con un átomo de nitrógeno terciario sobre él, separados por una corta

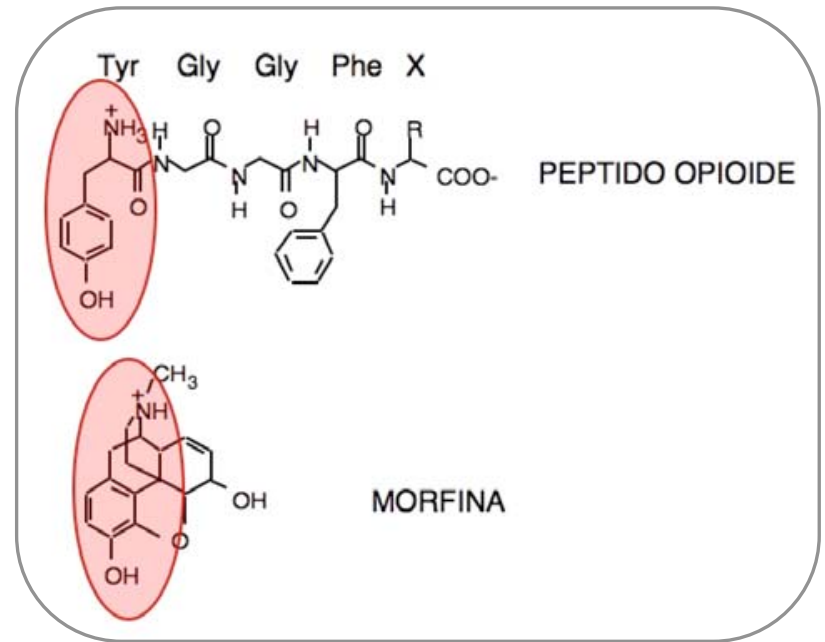

Figura 12: Comparación de la estructura química de la morfina y de un péptido opioide. Rodeado por un óvalo se señala el motivo común a las dos moléculas, que debe ser reconocido por lo receptores opioides. 
cadena hidrocarbonada. Este mimetismo estructural podría explicar porqué la morfina, un alcaloide de origen vegetal, actúa de forma específica sobre los receptores opioides como si se tratara de uno de sus ligandos endógenos, ya que se podría unir de manera similar al bolsillo de unión del receptor y producir un cambio conformacional que provoca la activación del receptor.

Tras la identificación y caracterización de las encefalinas se han descubierto muchos otros péptidos con actividad opioide, y estos presentan en su extremo amino terminal la secuencia peptídica de las encefalinas (Tabla 2).

\begin{tabular}{|c|c|c|c|}
\hline Precursor & Péptido Opioide & Secuencia Aminoacídica & Bibliografía \\
\hline Proencefalina (PENK) & \begin{tabular}{|l|} 
Met-ENK \\
Leu-ENK \\
Met-ENK-Arg-Phe \\
Met-ENK Arg-Gly-Leu \\
Péptido E \\
Péptido F \\
Amidorfina
\end{tabular} & $\begin{array}{l}\text { YGGFM } \\
\text { YGGFL } \\
\text { YGGFMRF } \\
\text { YGGFMRGL } \\
\text { YGGFMRRVGRPEWWMDYQKRYGGFL } \\
\text { YGGFMKKMDELYPMEPEEEANGSEILAKRYGGFM } \\
\text { YGGFMKKMDELYPMEPEEEANGSEILA }\end{array}$ & $\begin{array}{l}\text { Hughes y Cols., 1975; Noda y Cols., 1982; } \\
\text { Comb y Cols., 1982; Legon y Cols., } 1982\end{array}$ \\
\hline $\begin{array}{l}\text { Proopiomelanocortina } \\
\text { (POMC) }\end{array}$ & $\begin{array}{l}\beta \text {-Endorfina }(1-31) \\
\beta \text {-Endorfina }(1-27) \\
\beta \text {-Endorfina }(1-26) \\
\beta \text {-Endorfina }(1-17) \\
\end{array}$ & $\begin{array}{l}\text { YGGFMTSEKSQTPLVTLFKNAIIKNAYKKGE } \\
\text { YGGFMTSEKSQTPLVTLFKNAIIKNAY } \\
\text { YGGFMTSEKSQTPLVTLFKNAIIKNA } \\
\text { YGGFMTSEKSQTPLVTL }\end{array}$ & $\begin{array}{c}\text { Bradbury y Cols., 1976; Nakanishi y Cols., } \\
\text { 1979; Chang y Cols., } 1980\end{array}$ \\
\hline Prodinorfina (PDYN) & $\begin{array}{l}\text { Dinorfina A (1-17) } \\
\text { Dinorfina A (1-8) } \\
\text { Dinorfina B (1-13) } \\
\text { Dinorfina B (1-29) } \\
\alpha-\text {-neoendorfina } \\
\beta \text {-neoendorfina } \\
\end{array}$ & \begin{tabular}{|l} 
YGGFLRRIRPKLKWDNQ \\
YGGFLRRIR \\
YGGFLRRQFKVVT \\
YGGFLRRQFKVVTRSQEDPNAYSGEFDA \\
YGGFLRKYPK \\
YGGFLRKYP \\
\end{tabular} & $\begin{array}{c}\text { Goldstein y Cols., 1981; Kakidani y Cols., } \\
\text { 1982; Horikawa y Cols., 1983; Civelli y } \\
\text { Cols., 1985; Kangawa y Cols., } 1981\end{array}$ \\
\hline Pronociceptina (PNOC) & Nociceptina & FGGFTGARKSARKLANQ & $\begin{array}{c}\text { Reinscheid y Cols., 1995; Meunier y Cols., } \\
\text { 1995; Pan y Cols., } 1996\end{array}$ \\
\hline Proendomorfina (?) & \begin{tabular}{|l|} 
Endomorfina-1 \\
Endomorfina-2
\end{tabular} & $\begin{array}{l}\text { YPWF } \\
\text { YPFF }\end{array}$ & Zadina y Cols., 1997 \\
\hline
\end{tabular}

Tabla 2: Algunos de los péptidos endógenos caracterizados, junto con sus secuencias aminoacídicas, así como los precursores de los que se originan. En el caso de las endomorfinas todavía no se ha encontrado su precursor.

Aunque se ha intentado correlacionar un grupo de péptidos con un tipo de receptor opioide, lo cierto es que todos los péptidos endógenos presentan una alta inespecificidad (Figura 13). Mansour y cols. (1995b), demostraron que prácticamente todos los péptidos se unen a los tres tipos de receptores en el rango nanomolar, si bien los péptidos sin carga positiva en la "dirección" (como las encefalinas) presentan 
menor afinidad por el receptor opioide kappa. Por ello, se cree que el receptor kappa presenta una serie de requerimientos estructurales no compartidos con los receptores delta y mu. Asimismo se estableció que la secuencia de las encefalinas es suficiente para la unión al receptor delta, mientras que las encefalinas "extendidas" se unen mejor al kappa. En el caso del receptor mu parece que la secuencia Met-encefalina se ve favorecida sobre la de Leu-encefalina.

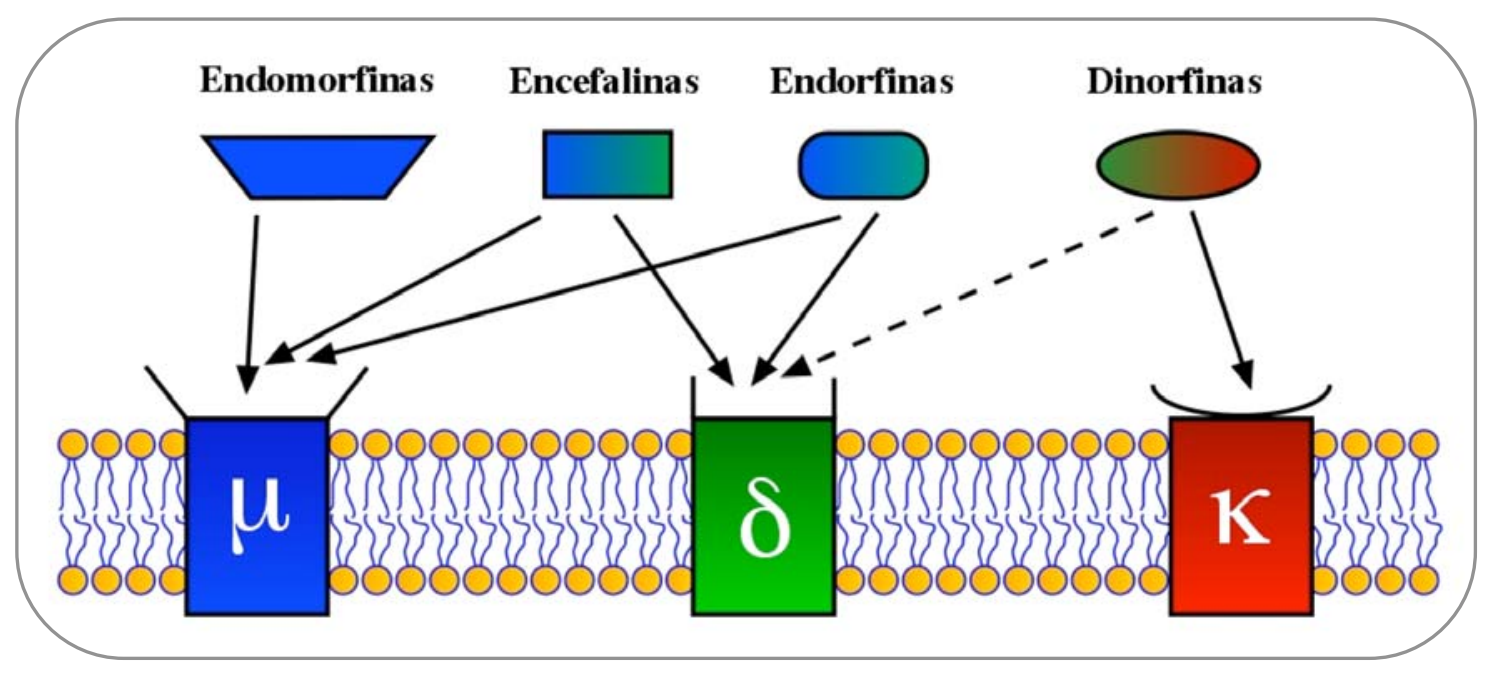

Figura 13: Relaciones de afinidad entre los péptidos endógenos y los receptores opioides mu, delta y kappa.

Por otra parte, un estudio llevado a cabo con la dinorfina $\mathrm{A}$ ha demostrado que este ligando es capaz no sólo de unirse y activar los tres tipos de receptores opioides, sino también presenta actividad agonista sobre el receptor ORL (Zhang y cols., 1998). En el caso de las endomorfinas, éstas presentan una alta afinidad por el receptor mu y muy baja por el delta y kappa (Zadina y cols., 1997). Finalmente, se ha determinado que la nociceptina actúa sobre el receptor ORL, aunque si el residuo de fenilalanina se sustituye por tirosina el péptido resultante tiene alta afinidad por los receptores kappa y mu (Reinscheid y cols., 1996). 
Los ligandos opioides endógenos demostraron no ser los compuestos idóneos para la caracterización farmacológica de los receptores opioides identificados, ya que presentan dos grandes inconvenientes: en primer lugar son compuesto de naturaleza peptídica por lo que pueden ser degradados rápida y fácilmente, además aunque se ha intentado correlacionar un tipo de receptor opioide con un grupo de péptidos opioides, se ha demostrado que los péptidos opioides se unen a los tres tipos de receptor sin mostrar una alta especificidad por ninguno de ellos (Mansour y cols., 1995b). Debido a, esto se han diseñado una serie de ligandos altamente selectivos para cada tipo de receptor opioide que, junto con determinados ligandos no selectivos, se utilizan para establecer el perfil farmacológico de los receptores opioides clonados. Dentro de estos ligandos se puede diferenciar entre agonistas, antagonistas y agonistas parciales, cuya naturaleza puede ser peptídica o no (Tabla 3).

Los receptores opioides delta presentan una alta afinidad por los agonistas DPDPE, DSLET, deltorfina II y el antagonista naltrindol, los cuales se unen con menor afinidad a los receptores mu y kappa. Además, se ha propuesto la existencia de subtipos de receptor delta de acuerdo con estudios farmacológicos y de comportamiento (Sofuoglu y cols., 1991): El receptor delta 1 , es activado selectivamente por DPDPE y bloqueado por el antagonista benzilidenenaltrexona (BNTX); y el receptor delta $_{2}$ es activado selectivamente por la deltorfina II y bloqueado por el antagonista naltriben (NTB). Podemos decir también que ambos subtipos son activados por las encefalinas y por la $\beta$-endorfina, y bloqueados con alta afinidad por el antagonista naltrindol (NTI). 
El receptor opioide kappa exhibe una alta afinidad por los agonistas U50,488 y U69,593 y por el antagonista nor-binaltorfimina (nor-BNI). Estudios farmacológicos sugieren la posible existencia de tres subtipos de receptores kappa (Clark y cols., 1989). Se ha caracterizado el compuesto U69,593 como agonista kappa 1 (de Lanerolle y cols., 1997); GR89,696 (4-[(3,4 - diclorofenil)acetil] - 3 - (1 - pirrolidinilmetil $)$ - 1 ácido piperazina carboxílico metil éster fumarato) que se comporta como agonista

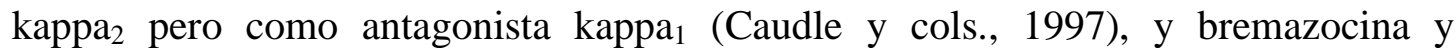
etilcetociclazocina (EKC) como agonistas kappa 2 (Rodríguez y cols., 2000). Por último, se ha descrito la naloxona benzilhidrazona (NalBZOH) como agonista kappa 3 (Paul y cols., 1990).

\begin{tabular}{|c|c|c|c|c|c|}
\hline \multirow[b]{3}{*}{ Receptor } & \multicolumn{5}{|c|}{ Ligandos } \\
\hline & \multicolumn{3}{|c|}{ Agonistas } & \multicolumn{2}{|c|}{ Antagonistas } \\
\hline & Endógenos & Peptídicos & No peptídicos & Peptídicos & No peptídicos \\
\hline Delta & $\begin{array}{l}\text { Leu-encefalina } \\
\text { Met-encefalina }\end{array}$ & \begin{tabular}{|l|} 
DPDPE \\
DSLET \\
DADLE
\end{tabular} & $\begin{array}{l}\text { BW373U86 } \\
\text { SNC } 80\end{array}$ & $\begin{array}{l}\text { ICI174.864 } \\
\text { TIPP }\end{array}$ & \begin{tabular}{|l|} 
Naltrindol \\
BTNX \\
Naltriben \\
\end{tabular} \\
\hline Kappa & $\begin{array}{l}\text { Dinorfina A } \\
\text { Dinorfina B }\end{array}$ & & \begin{tabular}{|l|} 
U50,488 \\
U69,593 \\
EKC
\end{tabular} & & Nor-BNI \\
\hline Mu & $\begin{array}{l}\text { Endomorfina } 1 \\
\text { Endomorfina } 2 \\
\beta \text {-endorfina } \\
\end{array}$ & $\begin{array}{l}\text { DAMGO } \\
\text { PL017 }\end{array}$ & \begin{tabular}{|l|} 
Morfina \\
Fentanilo \\
Sufentanilo \\
\end{tabular} & CTOP & $\begin{array}{l}\text { Naloxonacina } \\
\beta \text {-FNA }\end{array}$ \\
\hline No selectivo & & & \begin{tabular}{|l|} 
Etorfina \\
Metadona \\
Levorfanol \\
\end{tabular} & & \begin{tabular}{|l} 
Naloxona \\
Diprenorfina \\
Naltrexona
\end{tabular} \\
\hline
\end{tabular}

Tabla 3: Algunos de los ligandos selectivos empleados en el estudio de los receptores opioides.

Por su parte, el receptor mu presenta una alta afinidad por el agonista peptídico DAMGO, la morfina y su metabolito activo morfina-6- $\beta$-glucurónido, así como por los antagonistas CTOP y naloxonacina. La morfina, sin embargo, sí se une a los receptores delta y kappa aunque con afinidad baja. Estudios farmacológicos 
también sugieren la existencia de subtipos de receptores mu: $m_{1}$ y $m_{2}$, siendo éste último el que parece ser específico para la morfina (Pasternak y Wood, 1986). El antagonista naloxonazina se emplea para la diferenciación de los receptores mu en $\mathrm{mu}_{1}$ y $\mathrm{mu}_{2}$, al ser el subtipo $\mathrm{mu}_{1}$ sensible a naloxonazina, mientras que el subtipo $\mathrm{mu}_{2}$ es insensible a este compuesto (Pasternak, 2001).

2.11 Análisis de los sistemas de corte y empalme (Splicing) alternativo del receptor opioide mu de mamífero

Los mecanismos de corte y empalme (splicing) son los que transforman a un mensajero recién sintetizado en un mensajero maduro capaz de ser traducido; otros mecanismos implicados en el proceso de maduración son la poliadenilación del extremo 3' o la adición del la capucha (CAP) en el extremo 5'. El splicing alternativo es un mecanismo por el cual el procesamiento de los RNA inmaduros ( ${ }_{h n}$ RNA) produce más de un tipo de RNA mensajero maduro. Esto puede ser debido a la presencia de exones alternativos que se pueden incluir en la secuencia del mensajero o a pérdidas de alguno de los existentes. El proceso de splicing es complejo, varía según el tipo de RNA y en el intervienen un gran número de proteínas y ribonucleoproteínas. En el caso de los receptores opioides de mamíferos, los exones alternativos se encuentran localizados dispersamente entre los cuatro principales. Los primeros descubiertos se encontraban entre los exones 3 y 4, y hacia la región 3’ del locus génico, modificando las secuencias aminoacídicas del extremo carboxilo terminal. Recientemente (Pan y cols., 2001), han caracterizado cuatro nuevos exones alternativos, situados en la región 5’ del locus génico. De estos cuatro nuevos exones alternativos, el exón 11 situado a 5’ del exón 1, esta precedido por una región 
promotora y contiene en su secuencia un ATG iniciador, pudiendo comenzar en ese punto la transcripción.

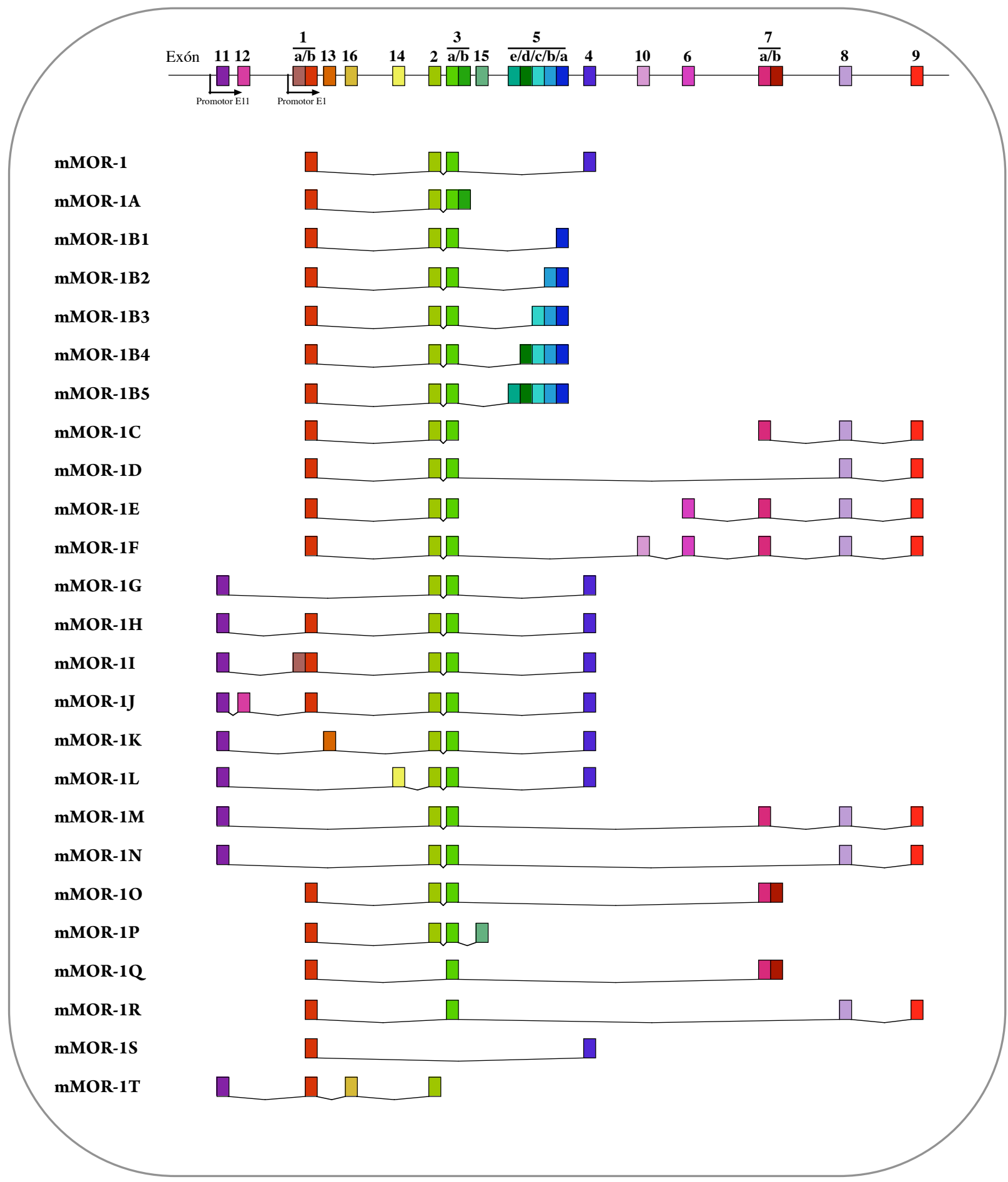

Figura 14: Esquema de las isoformas conocidas del receptor opioide mu de ratón, mostrándose las formas de procesamiento alternativo. En el mapa génico se muestran con flechas las zonas donde comienza la transcripción. El exón 1 puede ser procesado de dos formas originando el exón 1a (marrón oscuro) y el 1b (marrón claro). 
Así del procesamiento alternativo de los dieciséis exones caracterizados hasta el momento se han descubierto veinticinco isoformas del receptor opioide mu murino. De las nueve isoformas que tienen como primer exón el once, están truncadas las isoformas MOR-1G, MOR-1M y MOR-1N, que sólo presentan 6 dominios transmembrana, y las otras cinco dan lugar a proteínas de menos de $10 \mathrm{KDa}$. Las dos últimas en describirse, recientemente, han sido MOR1-1O y MOR1-1X, de significado biológico todavía incierto (Pan y cols., 2001; Cadet, 2004) (Figura 14).

\subsection{Transducción de la señal de los receptores opioides}

Todos los receptores opioides comparten los mismos mecanismos efectores a través de los cuales producen cambios específicos en el interior celular. Como se mencionó anteriormente los receptores opioides pertenecen a la superfamilia de receptores acoplados a proteínas $G$ heterotriméricas, principalmente del tipo $G_{\mathrm{i}} / \mathrm{G}_{0}$ sensibles a la toxina pertúsica (Reisine y cols., 1996), aunque cada vez hay más autores que encuentran que también pueden interaccionar con proteínas $\mathrm{G}_{\mathrm{z}}$, miembros de la familia de proteínas $\mathrm{G}$ inhibidoras insensibles a la toxina pertúsica (Law y cols., 2000) e incluso se ha apuntado la posibilidad de una interacción directa de los receptores opioides con las proteínas $\mathrm{G}_{\mathrm{s}}$, sensibles a la toxina colérica (Chakrabarti y cols., 1998; Szücs y cols., 2004).

Las proteínas $\mathrm{G}$ heterotriméricas se componen de una subunidad $\alpha$, con actividad GTPásica intrínseca, una subunidad $\beta$ y otra $\gamma$, estando estas dos últimas tan íntimamente relacionadas que se consideran como una unidad funcional (Figura 15). Hasta el momento se han descubierto 23 tipos de subunidades $\alpha, 5$ de $\beta$ y $11 \gamma$. Esta 
gran heterogeneidad implica el que en función de la combinación que se forme la respuesta ante la activación del receptor va a poder ser distinta. La subunidad $\alpha$ en su forma inactiva tiene unido GDP y se encuentra asociada al dímero $\beta \gamma$. Cuando la proteína $\mathrm{G}$ interactúa con el receptor activado se produce el intercambio de GDP por GTP liberándose la subunidad $\alpha$ del dímero $\beta \gamma$ y quedando activada. Tanto la subunidad $\alpha$ como la $\beta \gamma$ van a poder interactuar con la maquinaria de transducción de señales (Gudermann et al., 1997). La señalización por parte de la proteína G finalizará cuando la actividad GTPásica hidrolice el GTP a GDP produciéndose la inactivación de la subunidad $\alpha$ y la reasociación con el dímero $\beta \gamma$.

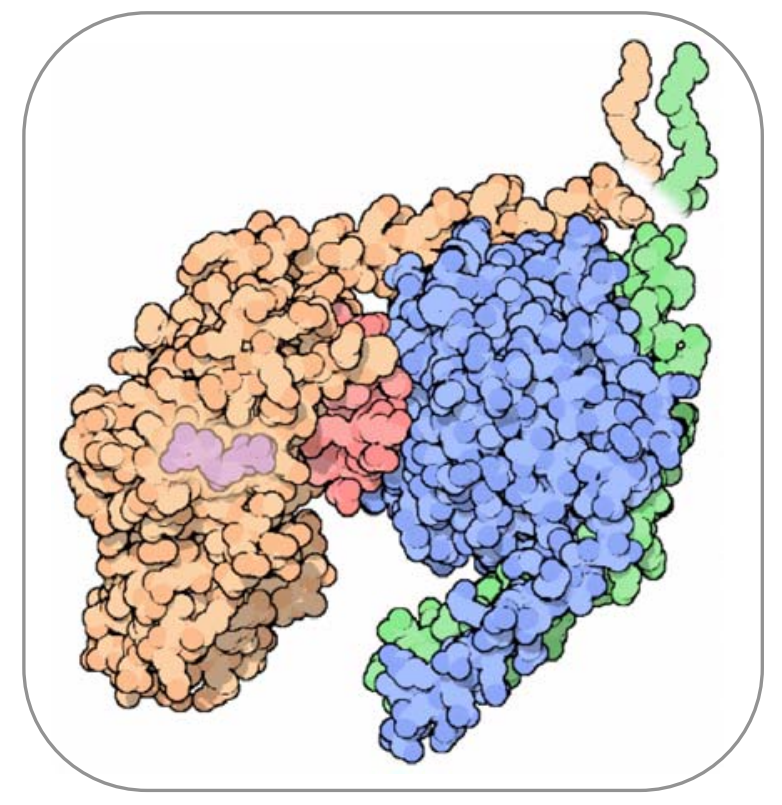

Figura 15: Representación la estructura de una proteína G heterotrimérica. En naranja se localiza la subunidad $\alpha$; en azul la subunidad $\beta$ y en verde la $\gamma$. También se pueden observar la hélices de anclaje de las subunidades $\alpha$ y $\gamma$ a la parte interna de la bicapa lipídica en la parte superior de la imagen. En morado se localiza la zona de unión del GDP en la subunidad $\alpha$ y en rojo una estructura en forma de lazo fundamental para la transducción de la señal.

La mayoría de las respuestas celulares mediadas por los recetores opioides comienzan por la activación de las proteínas $\mathrm{Gi} / \mathrm{G}_{0}$. Cuando un ligando se une al bolsillo de unión de un receptor opioide, se alteran las interacciones hidrofóbicas e hidrofílicas entre los segmentos transmembrana 3, 6 y 7, con lo que se produce un movimiento de las hélices que es transmitido al resto de la estructura del receptor. Este cambio conformacional provoca la exposición de los dominios intracelulares de interacción con la maquinaria de transducción de la señal transmitiéndose ésta al 
interior celular (Waldhoer y cols., 2004). Una vez se produce la activación de la proteína $\mathrm{G}$, la subunidad $\alpha_{\mathrm{i}}$ provoca la inhibición de la adenilato ciclasa sensible a forscolina, enzima unida a la cara interna de la membrana celular, por lo que se produce una disminución de la concentración de AMP cíclico intracelular (Figura 16). También se ha descrito la activación de determinados tipos de adenilato ciclasa mediado por el dímero $\beta \gamma$ (Chan y cols., 1995; Avidor-Reiss y cols., 1997). Así, la subunidad $\alpha_{\mathrm{i}}$ inhibe a las adenilato ciclasa I, V, VI y VIII, mientras que el dímero $\beta \gamma$ activa a los subtipos II, IV y VII.

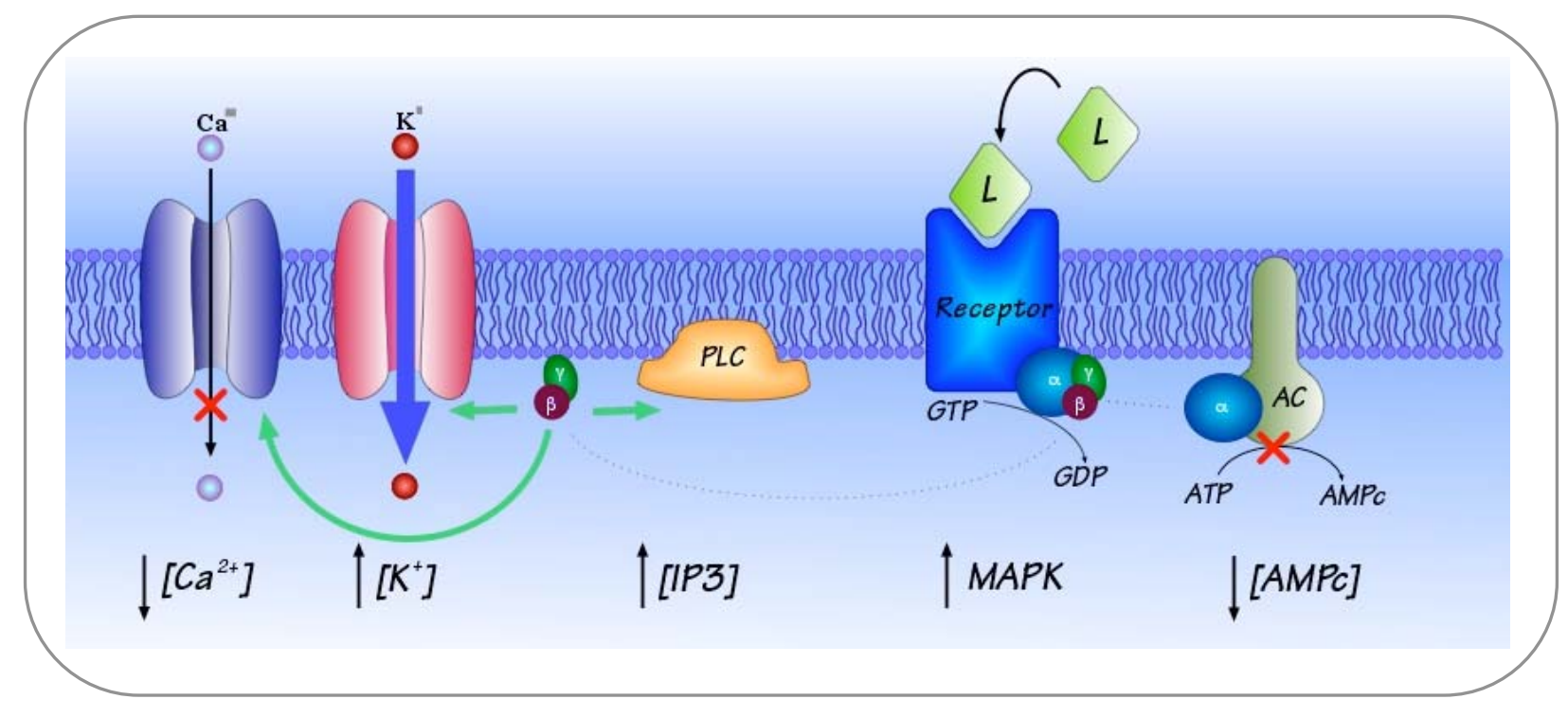

Figura 16: Esquema de los mecanismos de transducción de la señal al interior celular que siguen a la activación de un receptor opioide y su interacción con proteínas G. Las proteínas G interaccionan con los receptores activados, produciéndose el intercambio de GDP por GTP en la subunidad Ga $\alpha_{i}$. La subunidad $\alpha_{\mathrm{i}}$-GTP interacciona con la adenilato ciclasa e inhibe su actividad, con lo que disminuyen los niveles intracelulares de cAMP. A su vez, las subunidades $\beta \gamma$ inhiben los canales de $\mathrm{Ca}^{2+}$ y abren los canales de $\mathrm{K}^{+}$, por lo que se produce la hiperpolarización de la membrana plasmática y la inhibición de la liberación de neurotransmisores. Las subunidades $\beta \gamma$ también interaccionan con la fosfolipasa $\mathrm{C} \beta$, provocando la movilización de $\mathrm{Ca}^{2+}$ desde los depósitos intracelulares. Otro de los efectos de la activación de los receptores opioides es la activación de kinasas endógenas, tales como las MAP kinasas ERK1/2. Leyenda: L. ligando; R. receptor; AC. Adenilato ciclasa; PLC. Fosfolipasa C $\beta$.

Aunque la inhibición de la adenilato ciclasa es uno de los fenómenos más estudiados y mejor conocidos, los receptores opioides también modulan la actividad de ciertos canales iónicos, en concreto los receptores opioides activados se acoplan 
con un canal de potasio denominado GIRK1 (Inwardly Rectifying $K^{+}$Channel) a través de las proteínas $\mathrm{G}_{\mathrm{i}} / \mathrm{G}_{0}$ activas. Tras la interacción se produce un incremento en la conductancia al potasio, induciéndose la hiperpolarización de la membrana celular (Henry y cols., 1995). También pueden inhibir canales de calcio activados por voltaje de los tipos L, N, P/Q y R mediante una interacción directa con el dímero $\beta \gamma$, aunque se ha demostrado la necesidad de una subunidad $\alpha_{0}$ funcional para que este fenómeno tenga lugar (Law y cols., 2000; Borgland y cols., 2003). El resultado global de los efectos sobre los canales iónicos de potasio y calcio en el bloqueo de la liberación de neurotransmisores (Reisine, 1995).

Los receptores opioides van a poder modificar la concentración de calcio intracelular mediante otro mecanismo que incluye el heterodímero $\beta \gamma$. Éste va a poder interactuar con la fosfolipasa $\mathrm{C} \beta$, produciéndose un aumento en la concentración intracelular de inositol-1,4,5-trifosfato (IP3) y provocando una liberación del calcio de los depósitos intracelulares con canales sensibles a IP3 (Smart y Lambert, 1996; Law y cols., 2000). Esta movilización de calcio afectan a respuestas intracelulares mediadas por proteínas sensibles al calcio.

\subsection{Desensibilización e internalización de los receptores opioides.}

La exposición continua o repetida a ligandos opioides disminuyen la sensibilidad del receptor opioide y reducen la respuesta celular, siendo esta respuesta regulada por múltiples mecanismos. Un largo periodo de tiempo de exposición a los ligandos degrada el receptor y causa desensibilización (Law y cols., 1982, 1983, 1984; Cvejic y cols., 1996). Por el contrario, un tratamiento corto con ligandos 
opioides causa una rápida desaparición de receptores de la superficie celular como resultado de su endocitosis (Keith y cols., 1996; Sternini y cols.,1996; Trapaidze y cols., 1996 ). Ambos procesos requieren intacto el extremo carboxilo terminal de los receptores (Cvejic y cols., 1996; Trapaidze y cols., 1996). Aunque la deleción del extremo carboxilo terminal de los receptores opioides reduce substancialmente tanto la desensibilización como la rápida internalización, mutaciones puntuales en esta región reducen la capacidad de internalización sin afectar a la desensibilización, sugiriendo que estas dos respuestas son reguladas de forma diferente (Trapaidze y cols., 1996).

El mecanismo exacto de la internalización de los receptores opioides no es bien conocido, aunque se ha sugerido que la internalización de los receptores se lleva a cabo por la vía clásica de endocitosis. La fosforilación del receptor es un paso necesario para el proceso de internalización del mismo. Diferentes ligandos opioides inducen diferentes efectos en la internalización rápida de los receptores opioides. La morfina, a diferencia de la mayoría de los agonistas opioides, no induce internalización de los receptores opioides (Keith y cols., 1996; Arden y cols., 1995).

Está generalmente aceptado que la desensibilización inducida por agonistas se lleva a cabo a través de la fosforilación de los dominios intracelulares de los receptores (Figura 17). Varias kinasas han sido implicadas en la desensibilización de los receptores opioides, incluyendo la proteína kinasa dependiente de AMP cíclico (PKA), proteína kinasa C (PKC), y proteína kinasa II calcio-calmodulina dependiente (CaM Kinasa II) (Chen y cols., 1994; Mestek y cols., 1995; Koch y cols., 1997; Ueda y cols., 1995). Se han localizado sitios específicos de fosforilación que 
desempeñan un papel crítico en la desensibilización de homólogos de receptores opioides en el tercer dominio intracelular y en la cola carboxilo terminal, (Cvejic y cols., 1996; Koch y cols., 1997; Pak y cols., 1997). Un gran número de evidencias sugieren que la ruta principal de internalización de receptores que acoplan proteínas G es mediante la vía de fosas y vesículas recubiertas de clatrina para formar endosomas. En las condiciones ácidas de los endosomas, el ligando se separa del receptor, que es desfosforilado. Como último paso, el receptor es reciclado de vuelta a la superficie de la célula o es degradado (Dohlman y cols., 1991).

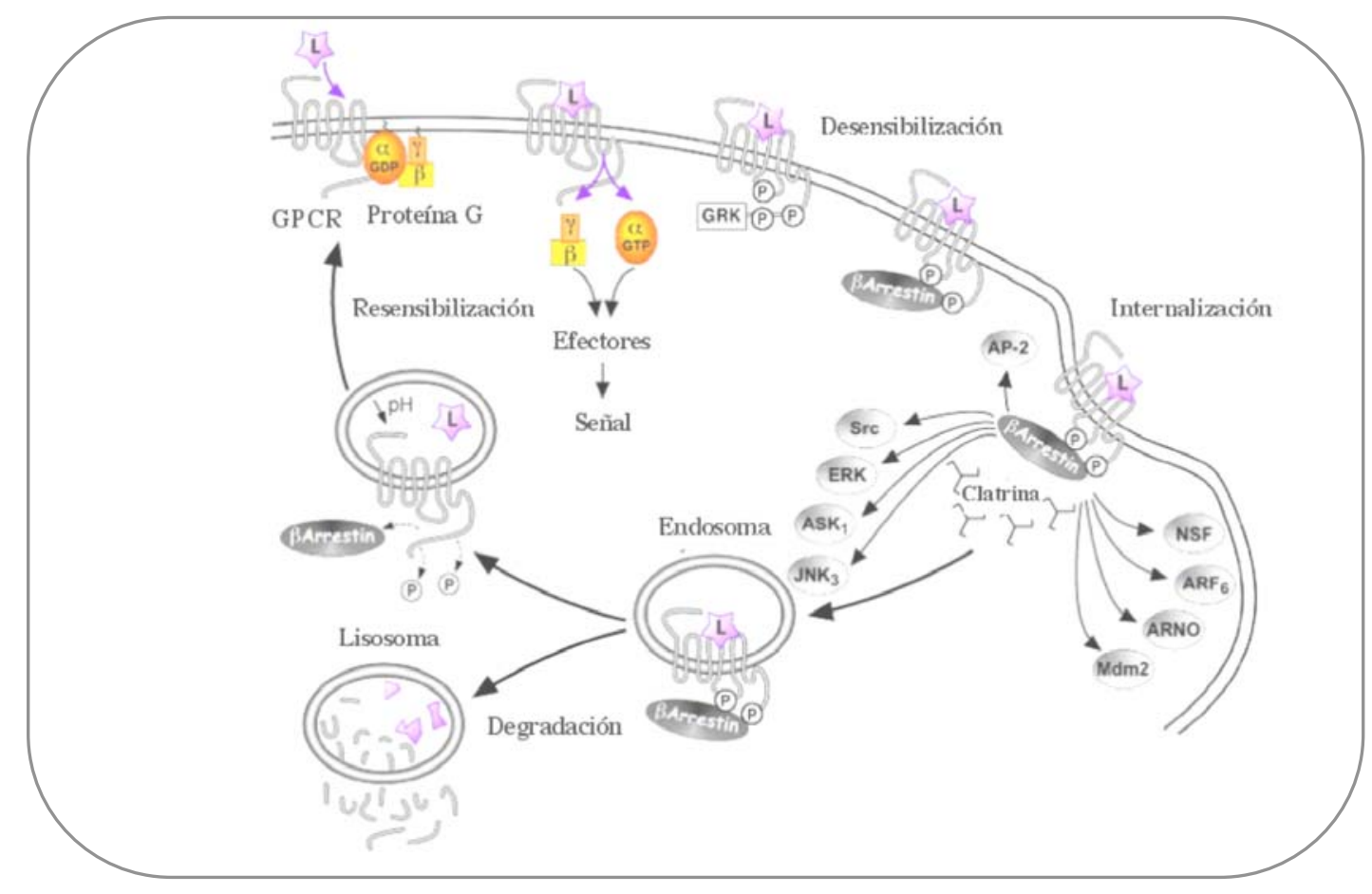

Figura 17: Los distintos procesos que tienen lugar tras la interacción de un receptor acoplado a proteínas $\mathrm{G}$ con su ligando correspondiente.

La desensibilización del receptor opioide mu de mamíferos es llevada a cabo por la CaM kinasa II mediante la fosforilación de los residuos de serina 261 y 266 localizados en el tercer dominio intracelular (Zimprich y cols., 1995). Otro sitio importante de fosforilación en el receptor opioide mu es la treonina que se encuentra 
en la posición 394, en la cola carboxilo terminal, que se ha observado que, cuando es sustituida por un residuo de alanina, retarda la desensibilización inducida por DAMGO, sugiriendo que ese aminoácido podría ser un objetivo primario para la fosforilación por GRKs (G-protein-coupled Receptor Kinase) que se unen al receptor opioide mu. También se ha visto que las isoformas que carecen de parte de la cola carboxilo terminal, y por tanto de la treonina 394, presentan mayor resistencia a la desensibilización producida por agonistas (Zimprich y cols., 1995; Koch y cols., 1998).

\subsection{Fenotipo de los ratones deficientes en el receptor opioide mu}

El avance de las técnicas de biología molecular ha permitido el desarrollo de ratones (y en otras especies), en cuyo genoma se ha delecionado de manera total o parcial un gen, impidiendo su expresión y por tanto anulando su función. En el caso del sistema constituido por los receptores opioides esta aproximación facilita la delimitación del papel que desempeña cada uno de los receptores en las respuestas farmacológicas tras la administración de sustancias opiáceas in vivo, ya que la respuesta in vitro es posible que no sea la misma debido a la complejidad del organismo completo.

El primer receptor opioide del que se obtuvo un knock out fue el mu. Para conseguirlo se interrumpió el gen a la altura del segundo exón, que corresponde al segundo lazo intracelular (Matthes y cols., 1996) o se delecionó el primer exón (Sora y cols., 1997). En ninguno de los casos se observó una reducción significativa de la viabilidad de los ratones homocigotos para la mutación respecto a los ratones no 
modificados de la misma camada. Tampoco se observaron diferencias en peso o tamaño, ni anomalías morfológicas graves. Cuando se analizaron los niveles de expresión del receptor opioide mu por unión del ligando selectivo DAMGO en membranas o en secciones de cerebro, se comprobó que se produce un efecto de dosis génica en los animales mutantes: los ratones heterocigotos presentan unos niveles alrededor del $50 \%$ respecto a los ratones normales. Los ratones homocigotos para la deleción no mostraron sitios de unión para DAMGO.

Respecto al comportamiento analgésico de estos ratones, no se encontraron diferencias en el umbral nociceptivo en las pruebas de placa caliente o inmersión de la cola (Matthes y cols., 1996), aunque en la prueba de desviación de la cola (tail-flick), los mutantes homocigotos mostraron latencias ligeramente menores que los normales (Sora y cols., 1997). Tras la administración aguda de morfina no se observa ningún efecto analgésico en las tres pruebas antes mencionadas cuando se utilizan los ratones homocigotos para la deleción; así mismo un tratamiento crónico con morfina no produce ningún síntoma de dependencia, ni se sobreviene el síndrome de abstinencia al tratar esos animales con naloxona, pese a que la alta dosis de morfina utilizada debería ser capaz de activar a los receptores delta y kappa (Matthes y cols., 1996). Sin embargo , el análogo de la morfina, la morfina-6- $\beta$-glucurónido y la heroína, que se pensaba que solo se unían al receptor opioide mu, si son capaces de inducir analgesia y disminución del tránsito intestinal en los ratones homocigotos para la deleción (Bolan y cols., 1997; Schuller y cols., 1997). 
Los modelos animales se han utilizado ampliamente en la investigación biomédica como consecuencia de la complejidad y problemas éticos que supone el estudio del ser humano. Un buen modelo animal debe reproducir situaciones clínicas o fisiopatológicas que permitan estudiar un determinado fenómeno y la posible aplicación de alternativas terapéuticas o, al menos, el mejor conocimiento de las mismas. Los modelos animales deben cumplir una serie de características que aseguren su efectividad, tales como que han de tener utilidades la clínica, ser cuantificable y fácilmente reproducible. El modelo animal debe presentar coherencia interna, es decir, debe haber una correlación entre los aspectos comportamentales, bioquímicos, fisiológicos y estructurales, lo que en muchos casos implica estudiar primeramente el propio modelo experimental en sí mismo. Finalmente, el modelo ha de ser validado y cumplir determinados requerimientos éticos, tales como la justificación de su uso, el empleo de procedimientos no lesivos e intentar utilizar un número mínimo de animales. Estas consideraciones éticas son clave en el caso del estudio

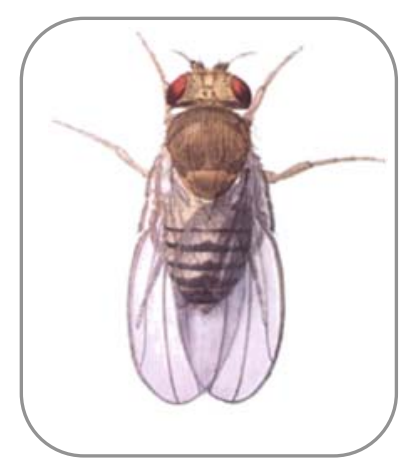

Figura 18: La mosca de la fruta Drosophila melanogaster del dolor y de la analgesia, ya que en muchos casos es necesario aplicar un estímulo doloroso, y en algunos de ellos esto implica un sufrimiento para el animal (GonzálezDarder, 2000). Los modelos animales más utilizados son los roedores, como la rata o el ratón, pero en determinados casos es necesario emplear animales filogenéticamente más cercanos al hombre como otros primates. A lo largo de la historia se han, y se siguen utilizando un gran número de modelos animales. Una de las aproximaciones clásicas para identificar genes implicados en el desarrollo de un organismo ha sido la 
búsqueda de mutaciones con un fenotipo claramente distinguible en la mosca de la fruta (Drosophila melanogaster) (Figura 18). La inducción de mutaciones hasta la saturación del genoma en Drosophila (Nüslein-Volhard y Wieschaus, 1980) ha permitido obtener mutantes en genes que intervienen en el desarrollo embrionario de este organismo para así poder determinar su funcionalidad; posteriormente se localizaron sus homólogos en vertebrados. Este sistema ha demostrado su validez para estudiar genes con función única e importante para el desarrollo embrionario, pero presenta algunas limitaciones (Nüsslein-Volhard, 1994), entre las que cabe destacar su dificultad para aplicarlo en la caracterización de genes pertenecientes a familias génicas con funciones complementarias, genes redundantes, genes letales en estadios de desarrollo tempranos o a mutaciones donde el fenotipo resultante no es claro o afecta a la formación de los órganos internos. Por último y fundamentalmente, hay procesos de desarrollo específicos de vertebrados, como la formación de la cresta neural, y sistemas o estructuras, como el sistema circulatorio, que son marcadamente diferentes.

Todo esto hace que se considere necesario abordar este tipo de estudios con un organismo vertebrado. Los modelos clásicos empleados hasta la fecha, como el sapo o el pollo, no son adecuados por su largo tiempo de generación y necesidad de espacio para su cría y cuidado; en el caso del ratón, se añaden las dificultades de su desarrollo intrauterino y el pequeño tamaño de la camada. 
El pez cebra (Danio rerio) (Figura 19) es un pequeño pez actinopterigio, del Superorden Teleostei, Orden Cypriniformes y Familia Cyprinidae. Este organismo, de entre 3 y $5 \mathrm{~cm}$ de largo en su edad adulta y con un característico patrón de bandas al que debe su nombre, es originario de aguas dulces del

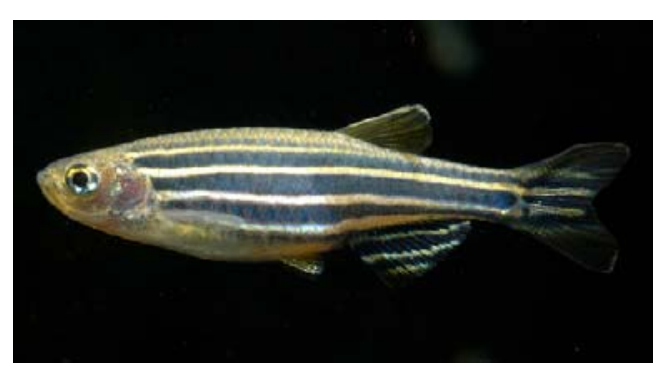
Figura 19: El pez cebra, Danio rerio. sureste asiático (cuencas de los ríos Ganges y Brahmaputra) (Spence y cols., 2006). Además de ser un típico habitante de acuarios domésticos, el pez cebra se ha incorporado recientemente al repertorio de organismos modelo para el estudio del desarrollo, junto con el ratón (Mus musculus), el pollo (Gallus gallus), el sapo Xenopus laevis, la mosca del vinagre (Drosophila melanogaster) y el nematodo Caenorhabditis elegans.

El pez cebra se escogió como modelo para llevar a cabo los estudios de mutagénesis hasta la saturación porque reúne varias ventajas (Streisinger y cols., 1981): su pequeño tamaño hace viable mantener en un espacio razonable la cantidad suficiente de líneas necesarias para realizar los cruces y los mutantes resultantes; su corto tiempo de generación, alrededor de tres meses, determina que transcurra menos de un año entre el proceso de mutagénesis y la obtención del mutante homozigoto; las puestas constan de cientos de huevos, lo que facilita el análisis genético. Además, otros modelos de vertebrados que también son adecuados para llevar a cabo estos estudios, presentan unos requerimientos mayores de espacio, mantenimiento y cría que encarecen los costes y los sitúan en desventaja frente al pez cebra (Dooley y Zon, 
2000). Una de las características más destacables de los embriones es que éstos se desarrollan en huevos completamente transparentes; a las 24 horas tras la fertilización se pueden distinguir fácilmente estructuras como notocorda, cerebro, corazón, ojos, y a los cinco días ya se pueden observar la mayoría de los órganos internos. También es posible obtener embriones haploides, a partir de los cuales se pueden desarrollar diploides homozigotos, que originan líneas de peces isogénicas (Driever y cols., 1994; Ingham, 1997). Puesto que el pez cebra es un vertebrado, en él se puede estudiar el desarrollo de estructuras típicas de este grupo, como el sistema excretor, el corazón con varias cámaras, la hematopoyesis con múltiples líneas celulares, así como la formación de la notocorda, tubo neural y crestas neurales.

Los estudios de mutagénesis a gran escala en el pez cebra han sido llevados a cabo por dos grupos de investigadores en Tübingen y Boston (Haffter y cols., 1996; Driever y cols., 1996). Como resultado han obtenido una colección de más de 6000 organismos mutantes, caracterizando casi 2000 de ellos, que se han asignado a cerca de 500 genes. Estas mutaciones afectan a casi todos los aspectos del desarrollo embrionario del pez cebra.

Recientemente se ha señalado al pez cebra como un sistema para determinar la funcionalidad de proteínas codificadas por el genoma humano, así como para estudiar el desarrollo del sistema nervioso e identificar anomalías metabólicas. También se está empleando para el estudio de ciertas patologías humanas, como desórdenes hematopoyéticos (porfirias, por ejemplo), anomalías cardiovasculares, destacando entre ellas las malformaciones aórticas en el feto, problemas renales y algún tipo de sordera. En este sentido, algunas de las mutaciones observadas afectan al desarrollo 
normal del corazón alterando su contractilidad pero sin modificar su morfología, de manera que imita a la cardiomiopatía dilatada (Xu y cols., 2002). También se han encontrado fenotipos que se corresponden con los producidos por arritmias (Rottbauer y cols., 2001), enfermedades cardíacas congénitas (Horne-Badovinac y cols., 2001), osteoporosis y enfermedades óseas congénitas, Parkinson, Alzheimer, sordera, diabetes, cirrosis, etc. (Shin y Fishman, 2002). También se ha estudiado el desarrollo del sistema inmune llegando a originar organismos que mimetizan algunas leucemias (Trede y cols., 2004).

Debido a su capacidad para incorporar moléculas disueltas en agua, el pez cebra puede emplearse para estudiar las interacciones entre el genoma y el medio ambiente; este screening químico podría emplearse como ensayo preclínico frente a tóxicos y, puesto que los embriones modifican su comportamiento tras la ingesta de alcohol o cocaína, el pez cebra podría ser utilizado como modelo para el estudio de la adicción (Dooley y Zon, 2000; Fishman, 2001). Así, en los últimos años, el pez cebra está siendo utilizado como organismo modelo para el descubrimiento de nuevas dianas para drogas, validación de estas nuevas dianas, estrategias en la búsqueda de nuevas drogas y estudios toxicológicos (Goldsmith, 2004). Además, la industria farmacéutica está empezando a explotar las semejanzas en regiones de unión a determinados fármacos y drogas entre las proteínas del ser humano y el pez cebra para el desarrollo de nuevas y mejores estrategias terapéuticas (Guo, 2004).

Varios autores ya han propuesto al pez cebra como un organismo modelo para el análisis de los efectos de diversas drogas como el alcohol (Gerlai y cols., 2000; 
Dlugoss y Rabin, 2003) y la cocaína (Darland y Dowling, 2001). Estos resultados son similares a los encontrados posteriormente en ratón (Anachtchik y cols., 2004).

Por otra parte, un aspecto fundamental para la utilización del pez cebra como modelo en el estudio del dolor es conocer si los peces sienten dolor. En un estudio con la trucha arco iris (Oncorhyncus mykiss) se ha demostrado que los peces tratados con estímulos dolorosos responden con determinados comportamientos, que no pueden catalogarse como simples reflejos. En estos estudios, además, la morfina tiene un efecto analgésico al reducir dichos comportamientos (Sneddon, 2003).

\subsection{El sistema opioide en el pez cebra}

En los últimos años se han clonado en nuestro laboratorio cinco receptores de pez cebra semejantes a los receptores opioides de mamíferos, a los que se han denominado: zfDOR1 (ZFOR1) (ZebraFish Opioid Receptor 1), que presenta homología con el receptor opioide delta de mamíferos (Barrallo y cols., 1998a y 1998b; Rodríguez y cols., 2000); zfMOR (ZFOR2), que presenta homología con el receptor opioide mu. (Barrallo y cols., 2000); zfKOR (ZFOR3), que presenta homología con el receptor opioide kappa (Alvarez, y cols., 2006); zfDOR2 (ZFOR4), que parece ser un duplicado de zfDOR1 y, por ello, presenta mayor homología con el receptor opioide delta (Pinal-Seoane y cols., 2006) y zfORL, que presenta homología con el receptor ORL (Rivas-Boyero, Tesis doctoral, 2003).

También se han identificado los precursores de los ligandos endógenos opioides correspondientes a dichos receptores, con el objeto de profundizar en la 
funcionalidad del sistema opioide en este organismo modelo (González-Núñez y cols., 2003 a, b y c). Para emplear este teleósteo como un organismo modelo para el estudio del dolor y de la drogodependencia, es necesario, aparte del estudio del sistema opioide, cuyo abordaje está siendo ampliamente acometido por nuestro grupo de investigación, sumergirse en otros sistemas relacionados, como es el sistema cannabinoide.

\subsection{8 zfMOR, el receptor opioide tipo mu de pez cebra}

El gen zfMOR está dividido en tres exones codificantes. El primer exón codificante contiene desde el codón de inicio hasta el residuo de arginina 87, localizado inmediatamente tras el primer segmento transmembrana; el segundo exón acaba en el residuo de serina 206 en el segundo lazo extracelular; y el tercer exón incluye el codón de parada. La organización del gen es similar a la del gen del receptor opioide mu en mamíferos, ya que los puntos de interrupción de la secuencia codificante se encuentran en la misma posición (Min y cols., 1994; Wang y cols., 1994a). Una diferencia importante entre los genes zfMOR y el del receptor opioide mu de mamíferos es que en éste último la secuencia codificante está dividida en cuatro exones y no en tres, debiendo destacar que el codón de parada de zfMOR se localiza donde se inserta el intrón entre los exones 3 y 4 en los mamíferos, al igual que ocurre con el gen ccMOR, un gen con alta homología con el receptor opioide mu procedente de otro teleósteo, Catostomus commersoni (Darlison y cols., 1997) (Figura 20). 


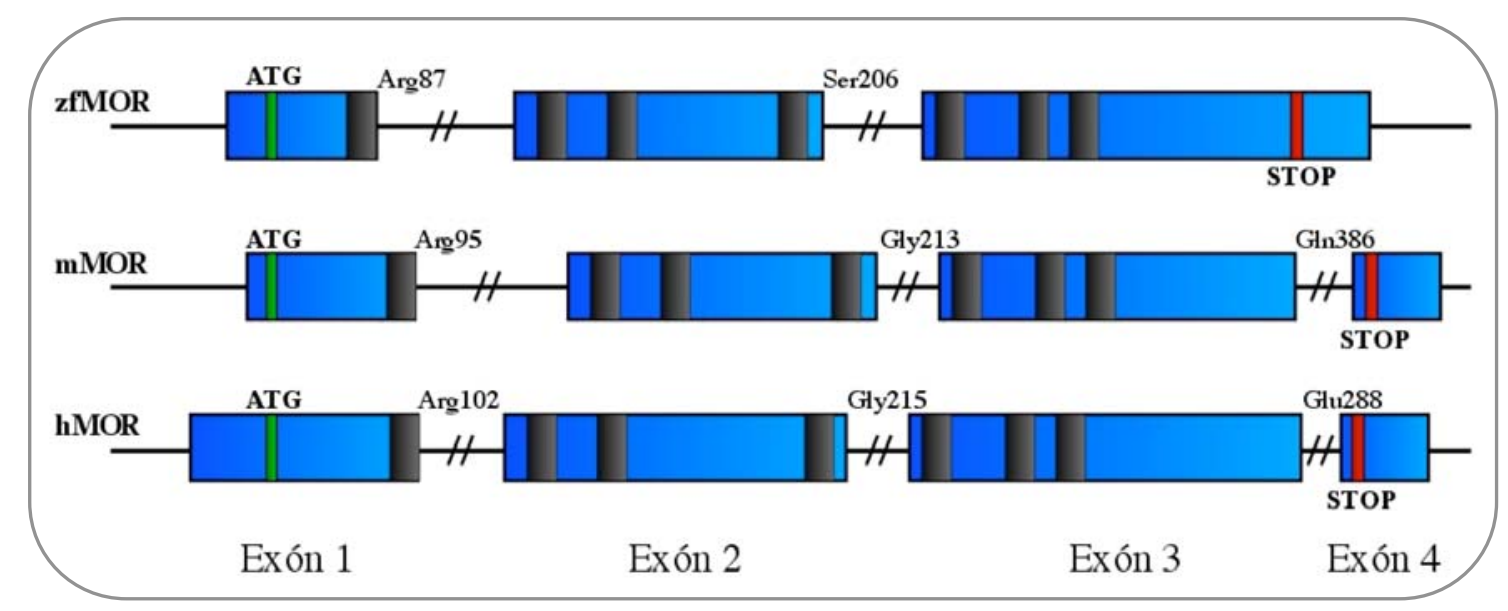

Figura 20: Comparación de la estructura genómica del gen zfMOR y los genes de los receptores opioides mu de ratón (mMOR) y humano (hMOR). Los rectángulos azules representan los exones, en los que se indican los codones de inicio (ATG) y parada (STOP), y con rectángulos negros las secuencias que codifican los potenciales segmentos transmembrana en el receptor. Asimismo, se señalan los aminoácidos y su posición en la secuencia de la proteína en los que se interrumpe cada exón.

Merece la pena resaltar que el residuo de treonina 394 situado en el exón 4 del receptor opioide mu murino se ha implicado en procesos de desensibilización del receptor inducida por la unión de un agonista, ya que este residuo puede ser sustrato de fosforilación por las GRKs (Pak y cols., 1997). Además, en la rata se ha identificado una isoforma de este receptor producto de un procesamiento alternativo con un cuarto exón distinto, que produce una proteína ocho aminoácidos más corta que no contiene este residuo de treonina (Zimprich y cols., 1995; Mayer y cols., 1996) y que se ha demostrado se desensibiliza más lentamente que la variante normal (Koch y cols., 1998; Wolf y cols., 1999). Por tanto, podemos suponer que la proteína codificada por el gen zfMOR podría tener un comportamiento ante la unión de un agonista distinto al que tiene el receptor opioide mu, y que el cuarto exón se ha adquirido a lo largo de la evolución de los mamíferos, tras separarse éstos en el evolución de la rama que daría lugar a los teleósteos actuales y le ha conferido al receptor unas propiedades distintas. 
La proteína codificada por el gen zfMOR está formada por 382 aminoácidos, con un peso molecular de 44,7 kDa sin contar las posibles glicosilaciones (Figura 21). Forma siete segmentos transmembrana, como los otros receptores opioides, y también pertenece a la superfamilia de receptores acoplados a proteínas G. Además de esta característica principal de la proteína codificada por zfMOR, en el dominio aminoterminal de la proteína que se dispone en el exterior celular se localizan, como ocurre en otros receptores de esta superfamilia, cinco residuos de asparragina potencialmente sustrato de N-glicosilación (7, 22, 29, 32 y 40). Además se encuentran seis residuos susceptibles de fosforilación por proteína kinasas en los dominios que se localizarían en el interior celular: treonina 172 en el segundo lazo intracelular, serina 256 y 263 y treonina 274 en el tercer lazo intracelular, y serina 361 y treonina 378 en el dominio carboxilo-terminal. Los residuos 132 y 212 son cisteínas localizadas en los lazos extracelulares 1 y 2 respectivamente, que podrían formar un puente disulfuro que estabiliza la estructura terciaria de la proteína Asimismo, los residuos 341 y 346 son cisteínas que quedan en el dominio carboxilo-terminal intracelular y son susceptibles de palmitoilación, formando un lazo intracelular adicional. La palmitoilación en cisteínas del extremo carboxilo terminal es un proceso bien conocido en los receptores con siete dominios transmembrana acoplados a proteínas G. Sin embargo, experimentos de incorporación de ácido palmítico marcado de forma radiactiva parecen demostrar que la palmitoilación no se produce en ninguna de las dos cisteínas del extremo carboxilo terminal en receptores opioides mu de rata (Chen, 1998). 


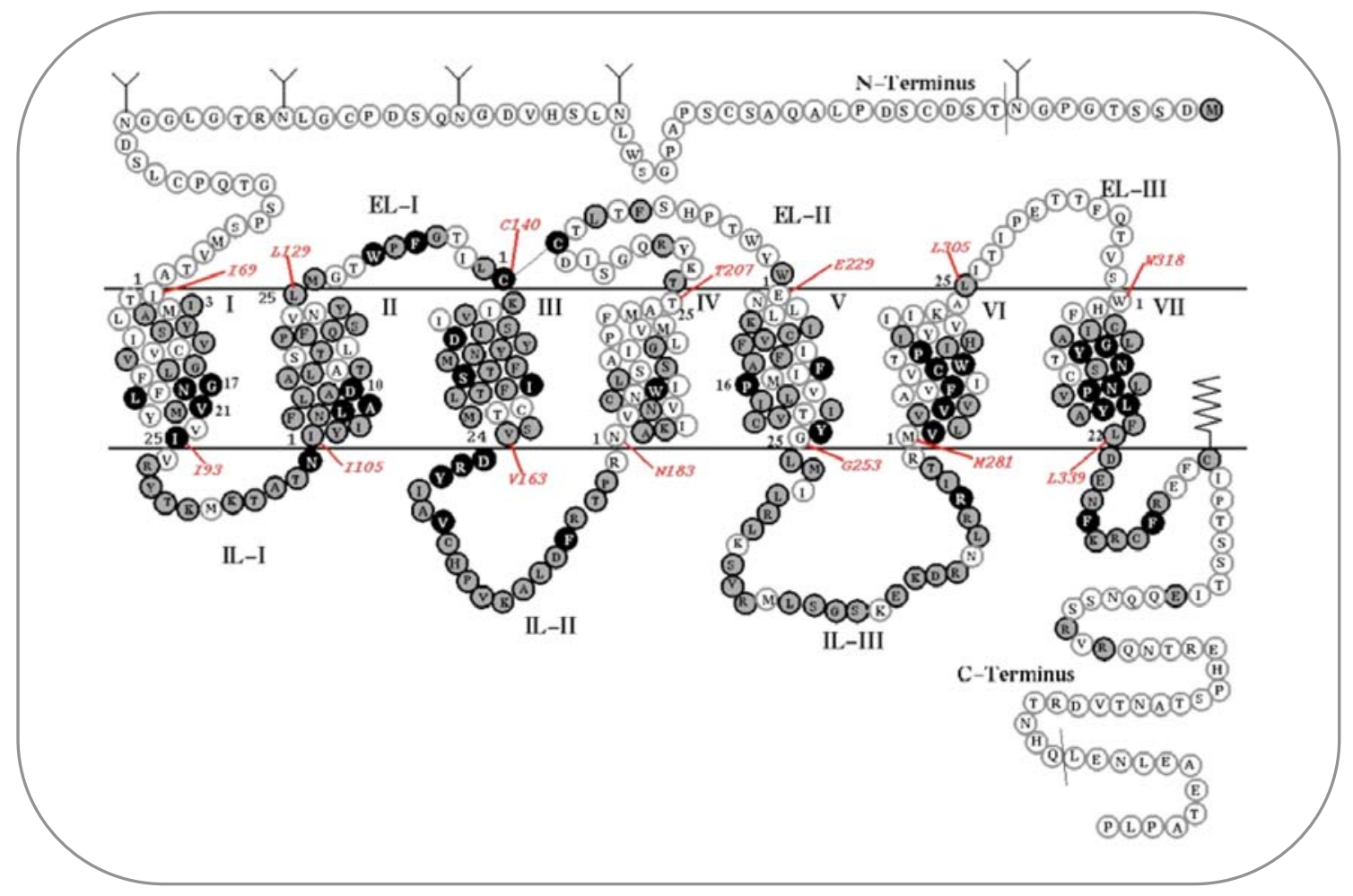

Figura 21: Esquema de la estructura del receptor opioide mu de rata. Se encuentran señalados los siete dominios transmembrana, los lazos intra y extracelulares que se forman y los extremos amino y carboxilo terminales. También se pueden ver residuos de asparragina glicosilados en el extremo amino terminal, el puente disulfuro entre residuos de cisteína de los lazos extracelulares primero y segundo y un cuarto lazo intracelular que aparece como consecuencia del anclaje del extremo carboxilo terminal mediante un resto de ácido palmítico a la membrana plasmática. En rojo se encuentran resaltados los aminoácidos que se creen forman los extremos de las hélices transmembrana, sin embargo esto es solo una aproximación ya que no se sabe exactamente el número que los forman. 


\section{Hipótesis y Objetivos}



Los receptores opioides median la respuesta frente al grupo de compuestos con la mayor capacidad analgésica conocidos y utilizados habitualmente a nivel clínico. Sin embargo, su utilización debe estar muy controlada debido a los efectos secundarios que producen, como la depresión respiratoria o trastornos intestinales. Desafortunadamente su utilización en contextos lúdicos es también muy alta y es aquí donde más se pone de manifiesto otra cara de la utilización de opiáceos que es la aparición de dependencia, tanto física como psicológica, asó como de tolerancia.

Nuestro grupo de investigación ha trabajado con éxito durante los últimos 12 años, analizando la función receptorial y la actividad opioide. En este sentido, hemos clonado 5 receptores opioides y 6 precursores de péptidos opioides, dentro de los cuales aparecen duplicados de los mismos, en el receptor de tipo delta, en la proencefalina y en la proopiomelanocortina. Además hemos descrito un péptido endógeno del pez cebra, denominado MEGY, que no se encuentra en otros organismos. Continuando en esta línea de investigación, nos propusimos como hipótesis de trabajo el caracterizar el receptor opioide mu de pez cebra con el objeto de probar si este receptor es un buen sistema para el estudio de la actividad opioide, en el sentido de ayudar a dar más luz en los temas del dolor, la tolerancia y la dependencia, y de forma especial al estudio de la relación "agente-receptor" de forma que se pueda utilizar como una herramienta que abra la puerta al diseño de nuevos fármacos. 
Para comprobar esta hipótesis nos propusimos los siguientes objetivos concretos:

1.- Determinar la posible existencia de duplicados del receptor opioide mu del pez cebra.

2.- Conseguir un sistema de expresión estable del receptor zfMOR.

3.- Probar la actividad biológica del receptor zfMOR:

a: Analizar si el receptor exhibe sitios de unión estereoespecíficos y saturables para agentes opioides

b: Estudiar la capacidad de unión de distintos agentes opioides al receptor zfMOR.

c: Estudiar los mecanismos de activación del receptor zfMOR.

d: Estudiar la capacidad de internalización del receptor zfMOR por distintos agentes opioides. 
Material y Métodos 



\subsection{Animales de experimentación}

Los peces cebra (Danio rerio, Hamilton-Buchanan 1822) se obtuvieron de un proveedor de animales domésticos de Salamanca, y se mantuvieron en acuarios dotados con un sistema de purificación y oxigenación del agua, a una temperatura constante de $26^{\circ} \mathrm{C}$ con un ciclo luz-oscuridad de $12 \mathrm{~h}$. Los animales se alimentaron una vez al día. En todos los experimentos se utilizaron animales de ambos sexos.

La manipulación de los peces se hizo siguiendo en todo momento las directrices aprobadas en la European Communities Council Directive el 24 de Noviembre de 1986 (86/609/EEC), así como según lo sugerido en la Declaración de Helsinki, y de acuerdo con la Guía para el Cuidado y Empleo de Animales de Laboratorio, adoptada y promulgada por el U.S. Nacional Institute of Health y el Comité Ético Español

\subsection{Extracción de RNA total de cerebro pez cebra}

Para la extracción de RNA total de tejido se empleó una modificación del método de Chomczynski y Sacchi. (1987), utilizando el reactivo Trizol ${ }^{\mathrm{TM}}$ (GIBCOBRL) como reactivo para aislar el RNA total. La extracción del cerebro de pez cebra se realizó sobre una superficie refrigerada mediante hielo seco evitando la congelación del tejido. A continuación se utilizó $1 \mathrm{ml}$ de Trizol por cada 100 mg de tejido, y se procedió a la homogeneización del mismo mediante un homogeneizador Brinkmann Polytron. Tras incubar el preparado durante 5 min. a temperatura ambiente, se realizó una extracción selectiva del RNA por separación de fases 
mediante la adición de $200 \mu \mathrm{l}$ de cloroformo por cada ml de Trizol inicial y centrifugación a 12000 g durante 15 min. a $4{ }^{\circ} \mathrm{C}$. El RNA obtenido en la fase acuosa se precipitó con un volumen de isopropanol igual a la mitad del Trizol utilizado en el primer paso y se centrifugó a 12000 g durante 10 min. a $4{ }^{\circ} \mathrm{C}$. A continuación tras retirar el isopropanol, el pellet obtenido se lavó con un volumen de etanol 70 \% igual al de Trizol utilizado en el primer paso y se centrifugó a 7000 g durante 5 min. a $4{ }^{\circ} \mathrm{C}$. Finalmente, después de eliminar el sobrenadante y secar el RNA para eliminar cualquier resto de etanol, se resuspendió en agua tratada con DEPC (dietilpirocarbonato $0,1 \%$, Sigma), incubando a $60^{\circ} \mathrm{C}$ durante $10 \mathrm{~min}$. para favorecer la disolución del mismo. La concentración del RNA se determinó por espectrofotometría a 260 nm (GeneQuant, Pharmacia Biotech), y se comprobó que la relación $\mathrm{A}_{260 / 280}$ se encontraba cercano a 2, correspondiente a muestras puras de RNA.

\subsection{Extracción de RNA total de células en cultivo}

Para la extracción de RNA a partir células en cultivo se partió de una placa de 24 pocillos utilizando un pocillo para cada extracción $\left(3,8 \mathrm{~cm}^{2}\right.$ de área de crecimiento). Las células con una confluencia aproximada del $80 \%$ se levantaron por pipeteo y se centrifugaron a $750 \mathrm{~g}$ durante $10 \mathrm{~min}$. El pellet celular resultante se resuspendió en $1 \mathrm{ml}$ de Trizol y se procedió de igual manera que en el protocolo anterior. 
Para la obtención del cDNA (DNA copia) se utilizó el kit ImProm-II ${ }^{T M}$ Reverse Transcripción System (Promega) siguiendo las especificaciones del fabricante. Inicialmente se desnaturalizó por calor una mezcla de $1 \mu \mathrm{g}$ de RNA total y $0.5 \mu \mathrm{g}$ del oligonucleótido oligo-dT a $70{ }^{\circ} \mathrm{C}$ durante $5 \mathrm{~min}$, tras lo cual se enfrió rápidamente en hielo. Este paso evita las posibles estructuras secundarias que puedan aparecer en los RNA. Posteriormente a esta reacción se añadió una mezcla preparada previamente que contenía $1 \mu \mathrm{l}$ de transcriptasa inversa ImProm-II ${ }^{\mathrm{TM}}, 4 \mu \mathrm{l}$ de buffer 5X ImProm-II ${ }^{\mathrm{TM}}, \mathrm{MgCl}_{2} 5 \mathrm{mM}$, una mezcla de dNTP (desoxinucleósidos trifosfato) $0.67 \mathrm{mM}, 20 \mathrm{U}$ del inhibidor de ribonucleasas Recombinant RNasin $^{\circledR}$ y agua libre de RNasas ( $\mathrm{ddH}_{2} \mathrm{O}$ tratada con DEPC) hasta un volumen final de $15 \mu$ l. La reacción se sometió durante 5 min. a $25^{\circ} \mathrm{C}$, lo que permite que el cebador anille con el RNA molde; posteriormente se incubó a $42{ }^{\circ} \mathrm{C}$ durante $1 \mathrm{~h}$, para que la retrotranscriptasa sintetice el cDNA. Finalmente la enzima se inactivó incubando $15 \mathrm{~min}$. a $70{ }^{\circ} \mathrm{C}$ las mezclas de reacción.

Para comprobar que la síntesis de cDNA se había realizado con éxito, se utilizaron controles positivos de la técnica, es decir, genes que se expresan de forma constitutiva y nos permiten confirmar que el proceso de síntesis de cDNA se ha llevado acabo de forma adecuada. En el caso del cDNA procedente de RNA de tejido de pez cebra se utilizó la amplificación del receptor opioide zfDOR1. En el caso de cDNA sintetizado a partir del RNA de las células HEK-293 se amplificó la GAPDH humana (Gliceraldehido 3-fosfato deshidrogenasa). También se llevaron a cabo controles negativos de la síntesis de cDNA para ellos sustituimos el RNA por agua 
libre de RNAsas; de esta forma nos aseguramos que la síntesis de cDNA únicamente se lleva a cabo por la presencia del RNA de interés. Los cebadores utilizados en los controles y los programas de amplificación empleados se detallan a continuación:

zfDOR1 Sentido: 5'- GAGCCGTCCGTCATTCCCG -3'

zfDOR1 Antisentido: 5'- GTAGTGGAGATTTGGGTGAC -3'

El programa utilizado en esta amplificación fue el siguiente: un paso inicial de $94{ }^{\circ} \mathrm{C}$ durante 5 min. para permitir una desnaturalización completa de todas las hebras de DNA o cDNA. Este paso va seguido de 30 ciclos con la siguiente secuencia: $94^{\circ} \mathrm{C}$ durante $30 \mathrm{~s}$ para permitir la denaturalización de las hebras de DNA, $55^{\circ} \mathrm{C}$ durante 30 s para permitir el anillamiento de los oligonucleótidos a las cadenas molde y $72{ }^{\circ} \mathrm{C}$ durante otros $30 \mathrm{~s}$ para permitir la síntesis por parte de la polimerasa. Una vez finalizados los 30 ciclos se añade un paso más de $72{ }^{\circ} \mathrm{C}$ durante 10 min. para garantizar que la polimerasa haya añadido una adenina terminal a todas las copias sintetizadas. Este hecho es de gran utilidad en el momento de clonar los productos de PCR (reacción en cadena de la polimerasa) en vectores, como se explicará posteriormente. De forma esquemática el programa utilizado se puede representar como:

Programa: $94{ }^{\circ} \mathrm{C}, 5$ min.; 30 ciclos $\left(94{ }^{\circ} \mathrm{C}, 30 \mathrm{~s} ; 55^{\circ} \mathrm{C}, 30 \mathrm{~s} ; 72{ }^{\circ} \mathrm{C}, 30 \mathrm{~s}\right) ; 72{ }^{\circ} \mathrm{C}, 10$ $\min$.

Los oligonucleótidos empleados en los controles positivos cuando se utilizó cDNA sintetizado a partir de RNA de células HEK-293 fueron: 
GAPDH Sentido: 5' - CCACCCATGGCAAATTCCATGGCA -3'

GAPDH Antisentido: 5' - TCTAGACGGCAGGTCAGGTCCACC -3'

Y el programa empleado:

Programa: $94{ }^{\circ} \mathrm{C}, 5$ min.; 35 ciclos $\left(94{ }^{\circ} \mathrm{C}, 30 \mathrm{~s} ; 55^{\circ} \mathrm{C}, 30 \mathrm{~s} ; 72{ }^{\circ} \mathrm{C}, 30 \mathrm{~s}\right) ; 72{ }^{\circ} \mathrm{C}, 10$ $\min$.

\subsection{Reacción en cadena de la polimerasa (PCR)}

La amplificación de DNA mediante la reacción en cadena de la polimerasa se realizó utilizando el sistema PCR Master Mix (Promega). Para ello, se mezclaron la mitad del volumen de la solución Master Mix 2X (buffer de la polimerasa pH 8.5, $\mathrm{MgCl}_{2} 3 \mathrm{mM}$, dNTPs $400 \mu \mathrm{M}$, Taq DNA polimerasa $\left.50 \mathrm{U} / \mathrm{ml}\right), 100 \mathrm{ng}$ de DNA y 0.1 $1 \mu \mathrm{M}$ de cada oligonucleótido. La reacción se llevó a cabo en un volumen final de 25 o $50 \mu$ l. Los oligonucleótidos fueron suministrados por Invitrogen de forma liofilizada siendo reconstituidos con agua estéril libre de RNAasas (Promega). Primero se obtuvo un stock a una concentración $100 \mu \mathrm{M}$ y posteriormente se hicieron alícuotas de trabajo de $10 \mu \mathrm{M}$ que se conservaron a $-20^{\circ} \mathrm{C}$. En todos los casos se realizó una reacción sin DNA molde como control negativo y otra utilizando el control negativo de la síntesis de cDNA. La reacción de amplificación se llevó a cabo en un termociclador Perkin Elmer (Geneamp® PCR system 9700). Los cebadores y el programa utilizado para la amplificación del receptor opioide mu del pez cebra fueron: 


\section{ZF Antisentido: 5' CTAGTCCTGGAGATGTCATCAC 3'}

Programa: $94{ }^{\circ} \mathrm{C}, 5 \min . ; 35$ ciclos $\left(94{ }^{\circ} \mathrm{C}, 1 \mathrm{~min} . ; 55^{\circ} \mathrm{C}, 1 \mathrm{~min} . ; 72^{\circ} \mathrm{C}, 1 \mathrm{~min}\right.$.); 72 ${ }^{\circ} \mathrm{C}, 10$ min.

La obtención de las construcciones de zfMOR con los epítopos antigénicos HA y FLAG también se llevó a cabo por PCR, mediante la utilización de oligonucleótidos con regiones no homólogas que permiten la inserción de pequeñas secuencias o cambios (Figura 22). En estos oligonucleótidos se añaden secuencias que no se van a anillar con el molde formando bucles; tras ser extendidos por la polimerasa las secuencias quedarán integradas dentro del fragmento sintetizado.

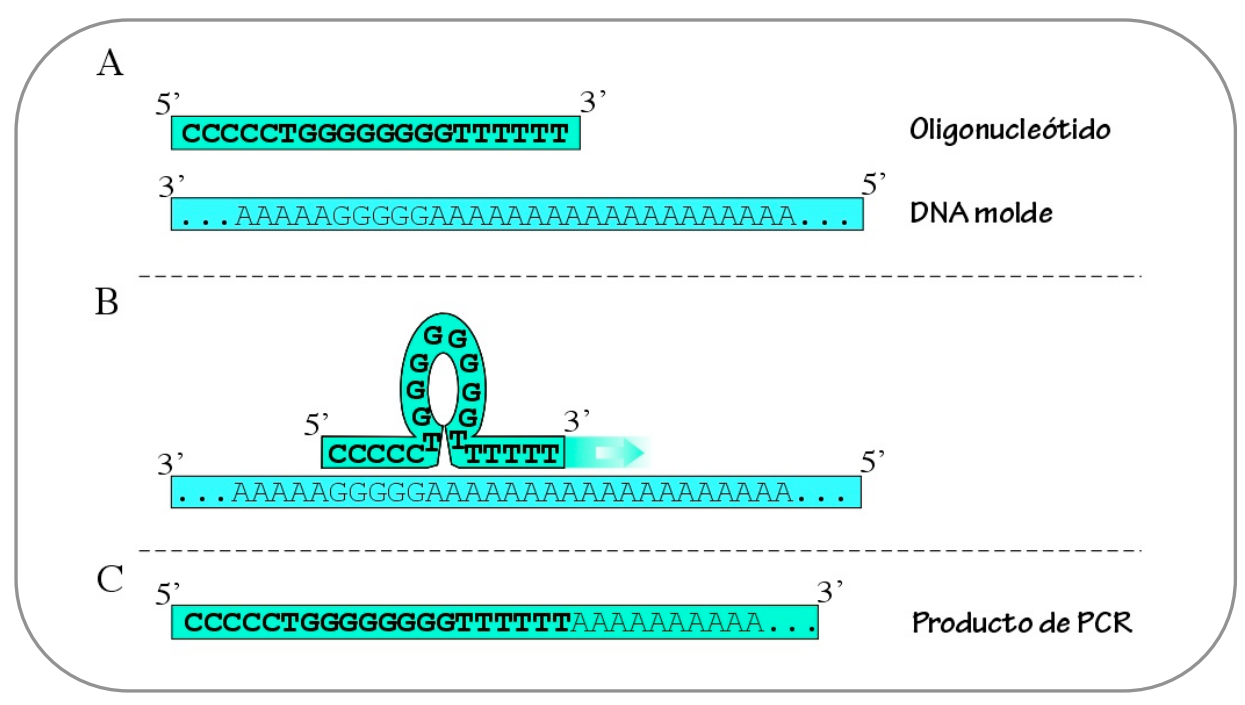

Figura 22: En esta figura se puede ver como utilizar la técnica de PCR para introducir pequeños cambios en la secuencia de un DNA dado. (A) Oligonucleótido diseñado para generar una inserción de 8 nucleótidos en la secuencia de DNA molde. (B) El oligonucleótido forma un bucle de forma que su zona complementaria al DNA molde puede anillar con éste y la polimerasa sintetizar a partir del extremo 3' libre. (C) El producto de PCR generado con los 8 nucleótidos incluidos en su secuencia.

El DNA molde utilizado para la PCR fue la construcción de zfMOR en pcDNA3.1. Para llevar a cabo esta PCR se utilizó la Taq DNA polimerasa (New England BioLabs) y se siguieron las recomendaciones del fabricante: Thermopol 
Buffer (20 mM Tris- $\mathrm{HCl} \mathrm{pH} 8.8,10 \mathrm{mM} \mathrm{KCl}, 10 \mathrm{mM}\left(\mathrm{NH}_{4}\right)_{2} \mathrm{SO}_{4}, 2 \mathrm{mM} \mathrm{MgSO}{ }_{4}, 0.1$ \% Tritón X-100), $200 \mu \mathrm{M}$ dNTPs, 0.2-0.5 $\mu \mathrm{M}$ de cada oligonucleótido, 0.5-2 U enzima y 50 pg de plásmido.

Programa: $94{ }^{\circ} \mathrm{C} 7$ min.; 30 ciclos $\left(94{ }^{\circ} \mathrm{C} 30\right.$ s, $63{ }^{\circ} \mathrm{C} 20$ s; $72{ }^{\circ} \mathrm{C} 2$ min.); $72{ }^{\circ} \mathrm{C} 10$ $\min$.

El termociclador utilizado fue un CETUR DNA termal Cycler (Perkin Elmer)

Los oligonucleótidos empleados se obtuvieron de Integrated DNA Tecnologies Inc. y sus secuencias se detallan a continuación. En azul se encuentra la parte de la secuencia correspondiente a la región 5 ' no traducida de zfMOR, en rojo el ATG iniciador de zfMOR, en verde las secuencias de los epítopos HA y FLAG y por último en granate la región 3' a partir del ATG iniciador de zfMOR (ver resultados para una explicación más detallada).

FLAG_zfMOR Sentido: 5’ AAC GCA CTT GCC ATG GAT TCA AAG GAT GAC GAC GAT AAG ATG GAA AAC ACT GGC 3'

HA_zfMOR Sentido: 5' AAC GCA CTT GCC ATG TAC CCA TAC GAT GTT CCA GAT TAC GCT ATG GAA AAC ACT GGC 3'

BSTEII_zfMOR Antisentido: 5' GGT CAC CAG AGC TTT GAT GAT 3'

Para la obtención del receptor delecionado se utilizó un método para originar cambios en plásmidos sin necesidad de subclonar basado en el trabajo de Fisher y Pei 
(1997). Para llevar a cabo esta PCR se utilizó la polimerasa Pfu (Stratagene) que nos confiere una alta fidelidad y permite tiempos de extensión muy largos. Una vez determinada la secuencia a delecionar se diseñaron dos oligonucleótidos que anillaran en los extremos de dicha zona (Figura 23). En este caso los oligonucleótidos son complementarios ya queremos que el producto de la PCR sea un DNA circular.

A

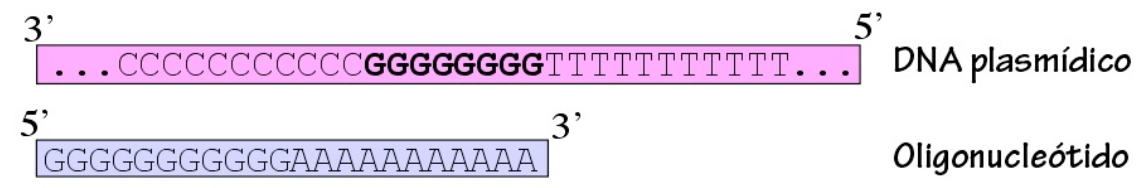

$\mathrm{B}$

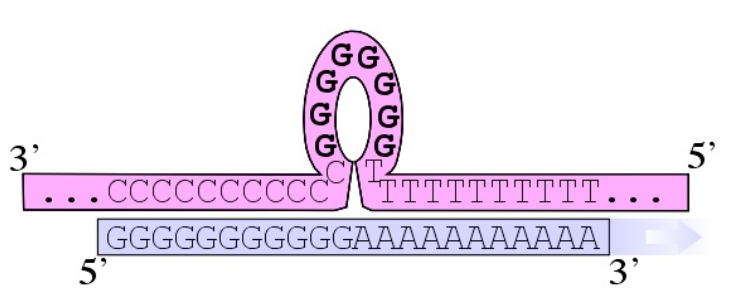

C

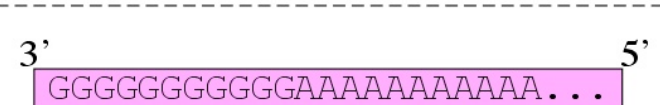

Producto de PCR

Figura 23: En esta figura se puede ver como utilizar la técnica de PCR para producir deleciones en la secuencia de un DNA dado. (A) Oligonucleótido diseñado para generar una deleción de 8 nucleótidos en la secuencia de DNA molde. (B) El DNA plásmídico forma un bucle de forma que su zona complementaria al oligonucleótido puede anillar con éste y la polimerasa sintetizar a partir del extremo 3' libre. (C) El producto de PCR generado es el DNA plasmídico con la deleción de 8 nucleótidos.

Los oligonucleótidos empleados se obtuvieron de Integrated DNA Tecnologies Inc. y sus secuencias se detallan a continuación. Se resalta con una barra vertical la zona donde se han suprimido las 9 bases. Con letras rojas se señala la secuencia que reconoce la enzima SalI y resaltado en azul los dos cambios realizados para generarla (ver resultados para una explicación más detallada). 
5SDL Sentido: 5' CCT GTT ATG GTC ATG GCG TCG ACC ACT | CAC TCG AAT GGC ATC ATT 3'

3SDL Antisentido: 5' AAT GAT GCC ATT CGA GTG | AGT GGT CGA CGC CAT GAC CAT AAC AGG 3'

Programa: $95^{\circ} \mathrm{C} 5$ min.; 18 ciclos $\left(95^{\circ} \mathrm{C} 30 \mathrm{~s}, 55^{\circ} \mathrm{C} 1\right.$ min., $68^{\circ} \mathrm{C} 6$ min. $)$.

\subsection{Electroforesis en gel de agarosa}

Los productos de la PCR fueron sometidos a electroforesis en geles de agarosa (0.8-1.5\% en función del tamaño de los fragmentos a separar) embebidos en TBE 0.5X (6.05 g Tris, $0.37 \mathrm{~g}$ EDTA, $2.67 \mathrm{~g} \mathrm{H}_{3} \mathrm{BO}_{3}$ y agua destilada hasta completar $11 \mathrm{de}$ disolución). Para poder monitorizar la migración del DNA a través del gel se utilizó un tampón de carga que contiene dos colorantes, el xileno-cianol y el bromofenol (Promega) que migran aproximadamente con fragmentos de 5.0 y $0.5 \mathrm{~Kb}$ respectivamente en geles de agarosa al $0.8 \%$. Además el tampón de carga confiere densidad a la muestra por lo que esta no difundirá libremente una vez depositada en los pocillos del gel. Paralelamente, en los geles se incluyó un marcador de peso molecular, que consistió en DNA del fago $\phi X-174$ digerido con la enzima de restricción HaeIII (Promega) y que genera fragmentos de tamaño: 1.35, 1.08, 0.87, $0.63,0.31,0.28,0.27,0.23,0.19,0.12$ y $0.07 \mathrm{~Kb}$. En los casos en los que los tamaños de las bandas esperadas fueran mayores se utilizó como marcador una mezcla de DNA de fago $\lambda$ digerido con la enzima de restricción HindIII y fago $\phi X-174$ digerido con la enzima HaeIII (Promega); este marcador de tamaño permite discriminar los siguientes fragmentos: $23.1,9.4,6.5,4.3,2.3,2.0,1.3,1,0.8,0.6,0.5,0.3,0.28,0.27$, 
$0.23,0.19,0.125,0.11$ y $0.07 \mathrm{~Kb}$. Para las construcciones del receptor con los epítopos antigénicos y los mutantes el marcador utilizado fue el TrackIt ${ }^{T M} 1 \mathrm{~Kb}$ Plus DNA Ladder (Invitrogen), que lo forman los siguientes fragmentos: 12, 11, 10, 9, 8, 7, $6,5,4,3,2,1.651,0.85,0.65,0.5,0.4,0.3,0.2$ y $0.1 \mathrm{~Kb}$. Las electroforesis se llevaron a cabo bajo una diferencia de potencial constante de 100-120 V durante 3060 min. en función del tamaño de la banda esperada y el porcentaje del gel (fuente de Biorad). En el caso de que alguna de las bandas observadas se fuese a purificar se disminuyó la diferencia de potencial hasta $80 \mathrm{~V}$ para evitar daños en el DNA.

La visualización del DNA tras la migración se realizó mediante la utilización de bromuro de etidio (Biorad) el cual se añade al gel antes de su polimerización (0.5 $\mu \mathrm{g} / \mathrm{ml})$. Este colorante actúa intercalándose entre las bases nitrogenadas del DNA y emitendo fluorescencia al exponerse a la luz ultravioleta (Johnson y Grosmann, 1977). El patrón de migración de fragmentos se registró con una cámara digital (Kodak DC290) bajo iluminación UV, usando el programa Kodak Digital Science 1D.

\subsection{Purificación de los fragmentos amplificados por PCR}

Los fragmentos de DNA amplificados por PCR se visualizaron como bandas en un gel de agarosa. Las bandas de interés se aislaron y se purificaron usando el producto Concert Rapid Gel Extraction System (GibcoBRL), siguiendo las instrucciones del fabricante. Así, la agarosa conteniendo el DNA se fundió a $60{ }^{\circ} \mathrm{C}$ durante 15 min. en tampón de solubilización (suministrada por el fabricante). Esta mezcla se añadió a un cartucho con una membrana especialmente diseñada para retener el DNA y se centrifugó 1 min. a 13000 rpm. El cartucho se incubó durante 5 
min. con tampón de lavado (suministrada por el fabricante), que contiene etanol para mantener el DNA precipitado, y se centrifugó dos veces durante 1 min. a 13000 rpm. Finalmente, el DNA se eluyó con tampón TE (Tris-HCl-EDTA) pH 8 precalentado a $60{ }^{\circ} \mathrm{C}$.

En el caso de las construcciones con FLAG y HA se utilizó el kit Geneclean II (Bio 101) siguiendo las indicaciones del fabricante. De esta forma tras medir la cantidad de DNA que hay en la muestra se añadieron 4.5 volúmenes de NaI y 0.5 volúmenes de TBE modifier dado que los geles utilizados son de TBE. A continuación y tras resuspender el glassmilk este se añadió en una proporción dependiente de la cantidad de DNA que hubiera en la muestra, generalmente entre 10 y $15 \mu$ l. Para permitir la unión del DNA al glassmilk se incubo durante 5 min. a temperatura ambiente agitando bien de vez en cuando para evitar la sedimentación del glassmilk. Tras este paso se centrifugo la muestra para permitir la separación entre el glassmilk y la solución, para esto basta con una centrifugación a 12000 rpm. durante 5 segundos. El pellet así obtenido se lavó tres veces con la solución New Wash utilizando entre 10 y 50 volúmenes de éste. Tras los lavados se secó completamente el pellet para eliminar los residuos de etanol. Por último el DNA unido al glassmilk se eluyó en agua o tampón TE (Tris-HCl, pH 7.6-8.0, 0.1 mM EDTA) en función de la utilidad que se le fuese a dar. Para ello el pellet se resuspendió en un volumen igual al de glassmilk utilizado y se centrifugo a $12000 \mathrm{rpm}$. durante $30 \mathrm{~s}$ posteriormente el sobrenadante se recogió evitando arrastrar glassmilk. En caso de que la cantidad inicial de DNA fuese muy pequeña se hizo una segunda elución ya que este paso aumenta la recuperación entre un 10 y un 20\%. La concentración y pureza del DNA 
se determinó mediante espectrofotometría a 260 nm, y se comprobó que la relación $\mathrm{A}_{260 / 280}$ se encontraba cercana a 1.8 , correspondiente a muestras de DNA puras.

\subsection{Concentración del DNA por precipitación}

En los casos en los que tras la purificación del DNA se obtuviesen concentraciones finales muy bajas o con elevada contaminación, se realizó una concentración mediante la precipitación con etanol. Para ello se añadieron 2.5 volúmenes de etanol $95 \%$ y acetato sódico $0.12 \mathrm{M}$ mantenido a $-20^{\circ} \mathrm{C}$. La muestra se incubó en hielo durante al menos 10 min. A continuación se centrifugó a 12000 rpm. durante 15 min. a $4{ }^{\circ} \mathrm{C}$, se decantó el sobrenadante y se secó para eliminar los restos de etanol. Una vez seco el DNA se resuspendió en agua o tampón TE (Tris-HCl, pH 7.6-8.0, 0.1 mM EDTA).

\subsection{Reacción de digestión}

Para llevar a cabo las reacciones de digestión de plásmidos se utilizaron las siguientes enzimas de restricción: EcoRI (Roche/Fermentas), NotI (Amersham), XbaI (Roche), BstEII (Roche), DpnI (Stratagene) y SalI (Roche).

Las reacciones de digestión se realizaron en todos los casos siguiendo las indicaciones del fabricante y con los tampones suministrados por los mismos. Las digestiones se llevaron a cabo en baño o termobloque durante un periodo de $1 \mathrm{~h}$. Para realizar las digestiones dobles se optó por digerir con una enzima de restricción y tras 
inactivarla por calor y llevar a cabo una purificación del DNA mediante precipitación cortar con la siguiente enzima.

\subsection{Reacción de ligación}

Los fragmentos de DNA purificados a partir de los geles de agarosa fueron clonados en el vector $\mathrm{pGEM}^{\circledR}-\mathrm{T}$ Easy (Promega), vector linealizado que presenta una desoxitimidina terminal en los extremos 3'; de esta forma se mejora la eficiencia de inserción de los productos de PCR con desoxiadenosinas terminales, que son añadidas por polimerasas termoestables, y también se disminuye la recircularización del plásmido sin inserto.

En el caso de los productos resultantes de la incorporación de los epítopos FLAG y HA, estos fueron clonados en el plásmido $\mathrm{pCR}^{\circledR}-\mathrm{TOPO}^{\circledR}$ (Invitrogen); éste, al igual que $\mathrm{pGEM}^{\circledR}$-T Easy también presenta una desoxitimidina terminal en cada extremo 3'.

Posteriormente los fragmentos de DNA que corresponden a secuencias que contienen pautas de lectura abierta completas correspondientes a un gen fueron subclonados en el vector de expresión pcDNA3.1 (Invitrogen), que permite la transcripción del gen que se encuentre bajo la influencia de su promotor CMV (citomegalovirus). 
La reacción de ligación se llevó a cabo empleando 25-50 ng del vector pGEM $^{\circledR}-\mathrm{T}$ Easy, $\quad$ pcDNA3.1, o pCR ${ }^{\circledR}-\mathrm{TOPO}^{\circledR}, 1 \mu \mathrm{l}$ de tampón de la T4-ligasa (Promega) a una concentración 10X ó bien $5 \mu \mathrm{l}$ de tampón 2X, 3-7.5 $\mu 1$ de inserto y 3 $\mathrm{U}$ de T4-ligasa en un volumen final de $10 \mu \mathrm{l}$. La reacción se incubó a $15^{\circ} \mathrm{C}$ durante toda la noche o durante un mínimo de $3 \mathrm{~h}$ a temperatura ambiente.

\subsection{Desfosfatación de los plásmidos}

Un paso previo a la ligación del inserto con el plásmido pcDNA3.1 consiste en cortarle con unas enzimas de restricción determinadas, que dependen de cómo se vaya a ligar posteriormente, y una desfosfatación. En el caso de pGEM ${ }^{\circledR}-\mathrm{T}_{\text {Easy o pCR }}{ }^{\circledR}$ $\mathrm{TOPO}^{\circledR}$ el proceso de desfosfatación no se requiere ya que al tener extremos no complementarios el porcentaje de autoligación es muy bajo, pero en el caso del plásmido pcDNA3.1 al cortar con una sola enzima se generan extremos cohesivos complementarios que se pueden volver a autoligar. Incluso al cortar con dos enzimas la posibilidad de autoligación también existe. Para la desfosfatación utilizamos la fosfatasa alcalina (Promega). Añadimos $4 \mu \mathrm{l}$ de la enzima al plásmido cortado y purificado $(20 \mu \mathrm{l})$ junto con $3 \mu \mathrm{l}$ de buffer CIP 10X (Calf Intestinal Phosphatase) y completamos con agua hasta un volumen final de $30 \mu$ l. Posteriormente se incuba a 37 ${ }^{\circ} \mathrm{C}$ durante 30 min. y a continuación 10 min. a $75^{\circ} \mathrm{C}$ para inactivar la enzima. Por último se purifica para evitar el exceso de sales.

\subsection{Preparación de medios y placas bacterianas}

Utilizamos distintos tipos de medios para el crecimiento bacteriano, por un lado medios sólidos para al aislamiento de colonias y medios líquidos para el 
crecimiento de una colonia. Los medios sólidos utilizados fueron el medio TYE (4 g $\mathrm{NaCl}, 5 \mathrm{~g}$ triptona, $2.5 \mathrm{~g}$ extracto de levadura, $7.5 \mathrm{~g}$ agar y enrasar a $500 \mathrm{ml}$ con agua bidestilada y esterilizado mediante autoclave; $25 \mathrm{ml} /$ placa) y el medio LB ( $5 \mathrm{~g} \mathrm{NaCl}$, $5 \mathrm{~g}$ triptona, 2.5 extracto de levadura $7.5 \mathrm{~g}$ agar, enrasar a $500 \mathrm{ml}$ con agua bidestilada y ajustar el pH a 7.4 y esterilizado mediante autoclave; $25 \mathrm{ml} /$ placa). Los medios líquidos utilizados fueron $2 \mathrm{XTY}$ (16g de triptona, $10 \mathrm{~g}$ de extracto de levadura, $5 \mathrm{~g}$ de $\mathrm{NaCl}$ y agua destilada hasta completar un volumen de $11 \mathrm{y}$ esterilizado mediante autoclave) y medio LB (igual que el de placa pero sin el agar). En el caso de preparación de bacterias súper competentes también se utilizaron los medios TYM, TFBI y TFBII se de detallan en el siguiente apartado. Los medios y las placas se mantuvieron a $4{ }^{\circ} \mathrm{C}$ hasta su utilización comprobando periódicamente la posible aparición de contaminaciones.

\subsection{Preparación de células súper competentes}

Una colonia de la cepa TG1 de E. coli se creció en $10 \mathrm{ml}$ de medio 2XTY a 37 ${ }^{\circ} \mathrm{C}$ durante 14-16 h en agitación. Posteriormente se inocularon $2 \mathrm{ml}$ del cultivo anterior en $100 \mathrm{ml}$ de medio TYM ( $2 \mathrm{~g}$ de bactotriptona, $0.5 \mathrm{~g}$ de extracto de levadura, $\left.2 \mathrm{ml} \mathrm{NaCl} 5 \mathrm{M}, 1 \mathrm{ml} \mathrm{MgSO}_{4} 1 \mathrm{M}\right)$ y se incubaron durante aproximadamente $2 \mathrm{~h}$ a $37^{\circ} \mathrm{C}$ en agitación hasta alcanzar una O.D.600 $=0.6$. A continuación, el cultivo se enfrió rápidamente en hielo, se transfirió a 2 tubos de $50 \mathrm{ml}$ y se centrifugó a 2500 rpm. durante 10 min. a $4{ }^{\circ} \mathrm{C}$. El botón celular así obtenido se resuspendió en $4 \mathrm{ml}$ de

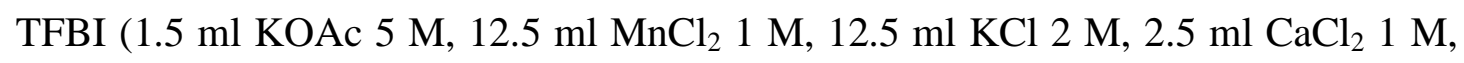
$37.5 \mathrm{ml}$ glicerol y agua bidestilada hasta $250 \mathrm{ml}$, filtrando para esterilizar) conservado a $4^{\circ} \mathrm{C}$. Tras centrifugar de nuevo en las mismas condiciones, se eliminó el 
sobrenadante y el botón celular se resuspendió en 4ml de TFBII (12.5 ml MOPS 2 M $\mathrm{pH} 7.0,18.8 \mathrm{ml} \mathrm{CaCl}_{2} 1 \mathrm{M}, 1.25 \mathrm{ml} \mathrm{KCl} 2 \mathrm{M}, 37.5 \mathrm{ml}$ glicerol, y agua bidestilada hasta $250 \mathrm{ml}$, filtrando para esterilizar) conservado a $4{ }^{\circ} \mathrm{C}$. Se realizaron alícuotas de $120 \mu 1$, que se guardaron en crioviales previamente etiquetados y éstos se congelaron directamente en nitrógeno líquido. Una vez congeladas, las células se mantuvieron en hielo seco hasta su almacenamiento a $-80{ }^{\circ} \mathrm{C}$.

\subsection{Transformación de células súper competentes}

$30 \mu \mathrm{l}$ de bacterias súper competentes se incubaron con 20-50 ng del producto de ligación durante $60 \mathrm{~min}$. en hielo. Pasado este tiempo, las bacterias fueron sometidas a un choque térmico a $42{ }^{\circ} \mathrm{C}$ durante $2 \mathrm{~min}$. y posteriormente se pasaron de nuevo a hielo durante $10 \mathrm{~min}$. A continuación, se añadieron $200 \mu \mathrm{l}$ de medio $2 \mathrm{XTY}$ y la mezcla se incubó a $37{ }^{\circ} \mathrm{C}$ durante 30 min. en agitación. Las bacterias así transformadas se sembraron sobre placas TYE suplementadas con $50 \mu \mathrm{g} / \mathrm{ml}$ de antibiótico (ampicilina o kanamicina). En el caso de que la construcción utilizada para transformar fuese pGEM-T Easy o pCR ${ }^{\circledR}-\mathrm{TOPO}^{\circledR}$ además se añadieron $50 \mu \mathrm{l}$ de IPTG (isopropil-1- $\beta$-D-tiogalactopiranosido) $(20 \mathrm{mg} / \mathrm{ml})$ y $50 \mu \mathrm{l}$ de X-Gal (5-bromo-4cloro-3-indolil- $\beta$-D-galactopiranosido $)(20 \mathrm{mg} / \mathrm{ml})$ a cada una de las placas como método de selección. Las placas sembradas se incubaron a $37{ }^{\circ} \mathrm{C}$ durante toda la noche (14-16 h). 
En el caso de utilizar el vector pGEM ${ }^{\circledR}$-T Easy y pCR ${ }^{\circledR}-\mathrm{TOPO}^{\circledR}$ las colonias resultantes de la transformación se seleccionaron por el color, ya que cuando el inserto se introduce en el vector, se interrumpe el gen de la $\beta$-galactosidasa, inactivándolo y por tanto las células no son capaces de degradar un sustrato, el X-Gal, acumulándose éste en forma de precipitado blanco; esto hace que las bacterias portadoras del inserto formen colonias de color blanco mientras que las no portadoras del inserto forman colonias de color azul porque el producto de la degradación del XGal es azul. Aquellas bacterias que no hayan adquirido el plásmido no serán capaces de crecer ya que no tendrán el gen que confiere la resistencia al antibiótico de selección. Las colonias bacterianas recombinantes se sembraron en $6 \mathrm{ml}$ de medio 2XTY suplementado con ampicilina o kanamicina, según el plásmido (50 $\mu \mathrm{g} / \mathrm{ml})$, y se dejaron crecer a $37{ }^{\circ} \mathrm{C}$ con agitación constante durante $12 \mathrm{~h}$ para la posterior purificación del DNA plasmídico. Además cada colonia se sembró también en una placa con medio TYE con antibiótico a modo de réplica. Cuando el plásmido utilizado fue pcDNA3.1 la selección con color no se realizó ya este plásmido no incluye el gen de la $\beta$-galactosidasa y por tanto todas las colonias son blancas.

\subsection{Purificación del DNA plasmídico}

El DNA plasmídico se extrajo empleando el sistema comercial Rapid DNA Plasmid Miniprep Kit (Gene Dan); para ello, el cultivo bacteriano se centrifugó durante 10 min. a 1500 rpm. y, tras decantar el sobrenadante, el botón bacteriano se resuspendió en $200 \mu \mathrm{l}$ de solución de resuspensión (suministrada por el fabricante). A 
continuación se añadieron $200 \mu \mathrm{l}$ de solución de lisis (suministrada por el fabricante) y la mezcla se incubó 60-90 segundos a temperatura ambiente. Seguidamente se añadieron $100 \mu \mathrm{l}$ de solución de precipitación (suministrada por el fabricante), se centrifugó 1 min. $13000 \mathrm{rpm}$. y se añadieron $150 \mu \mathrm{l}$ de solución de neutralización (suministrada por el fabricante). Tras centrifugar 5 min. a $13000 \mathrm{rpm}$., el sobrenadante se recogió en otro tubo y el DNA plasmídico se precipitó con $450 \mu \mathrm{l}$ de isopropanol. Después de centrifugar 3 min. a 13000 rpm., se eliminó el sobrenadante, se añadieron $100 \mu 1$ de solución purificante (suministrada por el fabricante) y se centrifugó 3 min. a 13000 rpm. El DNA se lavó con $750 \mu l$ de etanol $70 \%$, se centrifugó 2 min. a 13000 rpm., se secó y se resuspendió en agua bidestilada autoclavada o en tampón TE (Tris$\mathrm{HCl} 10 \mathrm{mM}$ pH 7.50; EDTA $1 \mathrm{mM})$.

Para analizar si las colonias seleccionadas contenían el inserto de interés, 2-5 $\mu l$ de cada preparación plasmídica se digirieron con las endonucleasas de restricción apropiadas, y la presencia de inserto se comprobó mediante electroforesis en geles de agarosa a diferentes concentraciones según el tamaño del fragmento esperado. Aquellas colonias que contenían el inserto de interés se crecieron en un volumen de $40 \mathrm{ml}$ de medio 2XTY suplementado con ampicilina o kanamicina, según el plásmido, a $37{ }^{\circ} \mathrm{C}$ con agitación constante durante $14-16$ h; parte del cultivo se almacenó a -80 ${ }^{\circ} \mathrm{C}$ utilizando glicerol al $20 \%$ como agente crioprotector. El resto se empleó para extraer el DNA plasmídico tal y como se ha descrito anteriormente. 


\subsection{Secuenciación automática del DNA}

Las reacciones de secuenciación automática de DNA se llevaron a cabo en el servicio central de secuenciación de la Universidad de Salamanca o en el servicio de secuenciación de la Universidad de Minnesota, ambos dotados de un secuenciador automático ABI Prism $^{\circledR}$ (Applied Biosystems). Para ello se mezclaron en un tubo eppendorf $5 \mu \mathrm{l}$ de DNA plasmídico, que equivalen a 400-600 ng de DNA, con 3 pmoles de oligonucleótido. En el caso de la secuenciación de fragmentos clonados en el plásmido pGEM ${ }^{\circledR}$-T Easy, se emplearon los oligonucleótidos PU y SP6 (Promega) y para los plásmidos $\mathrm{pCR}^{\circledR}-\mathrm{TOPO}^{\circledR}$ y pcDNA3.1, se emplearon los oligonucleótidos T7 y SP6 (Promega). Las limitaciones del sistema de secuenciación que dependen de muchos factores como la pureza y calidad del material a secuenciar, su concentración, la calidad de las enzimas utilizadas para la misma, etc. hizo necesario en algunos casos la utilización de oligonucleótidos que anillaban en el interior de la secuencia de zfMOR para así poder definir sin lugar a duda la secuencia intermedia (Figura 24).

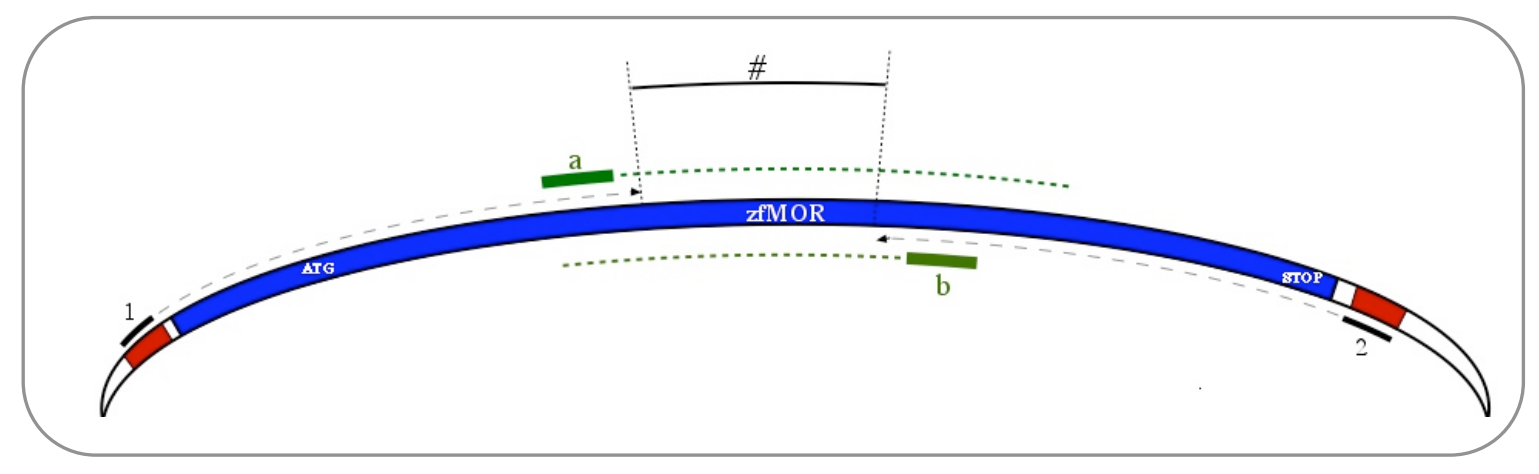

Figura 24: Este dibujo representa la necesidad de utilizar oligonucleótidos internos para secuenciar la ORF completa de zfMOR. Utilizando los oligonucleótidos (1 y 2 en la figura) que anillan en los extremos del plásmido (SP6 y T7 o PU, en función del plásmido utilizado) no llegamos a secuenciar la región central de zfMOR indicado con el símbolo \#. La utilización adicional de un oligonucleótido interno como los marcados como $a$ o $b$ nos asegura una secuenciación completa del fragmento de interés. 
Los resultados de la secuenciación, cromatograma y texto, fueron enviados por correo electrónico para ser analizados posteriormente. Las secuencias de los oligonucleótidos empleados fueron las siguientes:

SP6: 5' GATTTAGGTGACACTATAG 3'

T7: 5‘ TAATACGACTCACTATAGGG 3

PU: 5’ ATTTAGGTGACACTATAGAAT 3'

1115ZF: 5' CTGTTTTCGGGAGTTCTGTG 3'. Siendo este un oligonucleótido interno de zfMOR.

\subsection{Análisis de las secuencias}

El análisis de las secuencias recibidas desde el servicio de secuenciación automática se realizó con diversos programas informáticos. En primer lugar se visualizaron utilizando los programas EditView (ABI Automated DNA Sequencer Viewer, Perkin Elmer), Chromas 2.23 (Technelysyum Pty Ltd) o 4Peaks (A. Griekspoor y Tom Groothuis, mekentosj.com.). Para manipular las secuencias, buscar las pautas de lectura abierta, traducción de las secuencias de núcleotidos, obtener reversas y complementarias se empleó el programa DNA Strider 1.1 (Institute de Recherche Fondamentale) o la página web "The Sequence Manipulation Suite" (http://www.bioinformatics.org/sms).

La página del NCBI (National Center for Biotechnology Information: http://www.ncbi.nlm.nih.gov/) a través del programa BLAST o FASTA permitió comparar nuestras secuencias con las encontradas en la base de datos Gen Bank. La 
página del EMBL (European Bioinformatics Institute: http://www.ebi.ac.uk/), también sirvió para comparar secuencias. Gracias a los programas MEGA4 software (http://www.megasoftware.net) o ClustalW (http://www2.ebi.ac.uk/clustalw) se realizaron alineamientos de secuencias y con el primero se obtuvieron filogramas y análisis filogenéticos (Tamura y cols., 2007). La búsqueda de sitios de corte con endonucleasas de restricción se llevó a cabo con el programa DNA Strider 1.1 (Institut de Recherche Fondamentale) o con EnzimeX (A. Griekspoor y Tom Groothuis, mekentosj.com.).

Respecto a las bases de datos relacionadas con el pez cebra, se trabajó con: http://zfin.org/cgi-bin/webdriver?MIval=aa-ZDB_home.apg, http://www.ncbi.nlm.nih.gov/genome/seq/DrBlast.html, http://www.sanger.ac.uk/Projects/D_rerio/

\subsection{Cultivos celulares}

Para la realización de los experimentos se utilizó la línea celular HEK-293 (células embrionarias de riñón humano; ATCC: CRL-1573) (Figura 25). El medio utilizado para crecer las células fue DMEM (Gibco-BRL) (high glucose, no glutamate) suplementado con $2 \mathrm{mM}$ Glutamina (Biowhittaker) $10 \%$, suero bovino fetal descomplementado (Sigma o Biowhittaker), $100 \mathrm{U} / \mathrm{ml}$ de Penicilina (Sigma), 0.1 $\mathrm{mg} / \mathrm{ml}$ Estreptomicina (Sigma) y $25 \mu \mathrm{g} / \mathrm{ml}$ de fungizona (antifúngico de Biowhittaker). Tras suplementar el medio este fue esterilizado por filtración a través de filtros de $500 \mathrm{ml} \mathrm{y} \mathrm{de} 0,22 \mu \mathrm{m}$ de tamaño de poro (Corning). 


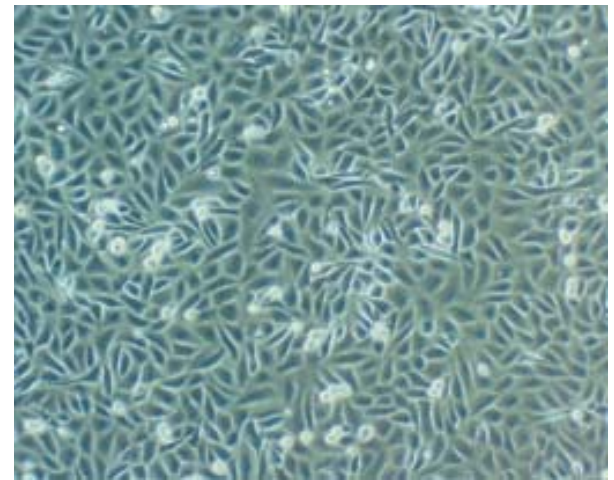

Figura 25: Células HEK-293 en crecimiento sobre la placa de cultivo. Estas células son de relativo pequeño tamaño y crecen en monocapa. Se pueden utilizar una variedad de medios de cultivo para su crecimiento siendo el más utilizado el DMEM. Estas células expresan muchas proteínas típicas de células neurales y ya en 1977, cuando fueron descritas, se propuso que provenían de células de origen neural.

Las células se incubaron a $37^{\circ} \mathrm{C}$, con $\mathrm{CO}_{2}$ al $5 \%$ y $95 \%$ de humedad en un incubador Nuare o Forma Scientific. Se cambiaron de medio cada 2 ó 3 días y el crecimiento se llevó a cabo hasta un 90-95 \% de confluencia, procediéndose seguidamente a la resiembra en nuevas placas.

Puesto que las células HEK-293 utilizadas no se adhieren fuertemente al sustrato para resuspenderlas se pudo utilizar el método de pipeteo aunque se optó en la mayoría de los casos una solución de PBS EDTA $2 \mathrm{mM}$. El EDTA va a actuar quelando iones de calcio necesarios para la unión de las células al sustrato, de esta forma se levantan las células de la botella (flask) donde crecen y se puede propagar el cultivo. Una vez toda la capa de células está levantada se pasan a un tubo de $50 \mathrm{ml}$ y se centrifuga a $750 \mathrm{rpm}$. durante $10 \mathrm{~min}$. a temperatura ambiente. Seguidamente se decanta el sobrenadante y el botón celular se resuspende en medio de cultivo y se distribuye en nuevas placas.

\subsection{Medición de las concentraciones de $\mathrm{CO}_{2}$ en los incubadores}

Puesto que la concentración de $\mathrm{CO}_{2}$ es un factor importante para el correcto crecimiento de las células se llevó a cabo un control periódico del mismo. La 
medición de la concentración de $\mathrm{CO}_{2}$ se llevo a cabo con analizador de gas Fyrite ${ }^{\circledR}$ (Bacharach Inc). Este sistema consta de una cápsula con un líquido capaz de absorber de forma selectiva el $\mathrm{CO}_{2}$. Mediante la utilización de una bomba se introduce aire directamente del incubador y en función de la concentración de $\mathrm{CO}_{2}$ el volumen del líquido aumentará de forma que una escala graduada nos da el valor exacto de la concentración. La medición del $\mathrm{CO}_{2}$ se realizó siempre a primera hora de la mañana antes de que el incubador hubiese sido abierto y en caso de encontrarlo descalibrado se calibró y volvió a comprobar transcurrida una hora.

\subsection{Transfección}

La transfección se llevó a cabo utilizando dioctadecildoglicil-espermina (DOGS), una lipoamida sintética de naturaleza catiónica (Transfectam ${ }^{\circledR}$, Promega). La elevada carga positiva del grupo espermida confiere a la molécula una alta afinidad por el DNA, cubriendo a éste con una capa lipídica catiónica que facilita su unión a la membrana celular.

Las células HEK-293 se crecieron en placas de 12 pocillos hasta alcanzar una confluencia no superior al $70 \%$, incubando las células a $37{ }^{\circ} \mathrm{C}$, con $\mathrm{CO}_{2}$ al $5 \%$ y 95 $\%$ de humedad, en medio DMEM suplementado con L-Glutamina, antibióticos, antifúngico y suero bovino fetal. Para llevar a cabo la transfección se procedió a eliminar el medio de la placa y a añadir $500 \mu \mathrm{l}$ de medio fresco. En dos tubos eppendorf se preparó de forma independiente una mezcla que contenía $1 \mu \mathrm{g}$ por pocillo del vector pcDNA3.1 con el inserto del clon de interés más $9 \mu$ de medio DMEM y en el otro tubo $1 \mu \mathrm{l}$ de $\operatorname{Transfectam}^{\circledR}(2 \mathrm{mM})$ por pocillo más $9 \mu \mathrm{l}$ de DMEM. Seguidamente se mezcló el contenido de los dos eppendorf y se incubó todo 
ello 10 min. a temperatura ambiente. A continuación la mezcla fue añadida a cada pocillo, se agitó suavemente dejándola en contacto durante $2 \mathrm{~h}$. Al cabo de ese tiempo se completó cada pocillo con $1 \mathrm{ml}$ del medio antes descrito incubando las células en un incubador a $37{ }^{\circ} \mathrm{C}, 5 \%$ de $\mathrm{CO}_{2}$ y $95 \%$ de humedad hasta la extracción de membranas, o extracción de RNA, o bien hasta realización del procedimiento para conseguir células estables (aproximadamente $48 \mathrm{~h}$ ).

\subsection{Obtención de clones estables}

Tras determinar el éxito de la transfección mediante la extracción de RNA y la realización de la RT-PCR utilizando oligonucleótidos específicos de la secuencia insertada, se procedió a la obtención de clones estables. Para dicho cometido se empleó G-418 (Neomicina) (Gibco-BRL) como antibiótico de selección, ya que el plásmido transfectado posee un gen marcador de resistencia a neomicina. Tras $48 \mathrm{~h}$ de la transfección las células se levantaron por pipeteo, y se centrifugaron a $750 \mathrm{~g}$ durante $10 \mathrm{~min}$. Posteriormente el botón celular se resuspendió en medio fresco completo y suplementado con G-418 a una concentración final de $500 \mu \mathrm{g} / \mathrm{ml}$ y se distribuyó en placas de 24 pocillos, $500 \mu$ l por pocillo. El objeto del pase de las células de cada pocillo de placas de 12 pocillos a 12 pocillos de placas de 24 es el de diluirlas para asegurar que las colonias estables que se formen crezcan lo más aisladamente posible. La selección se llevó a cabo durante un periodo mínimo de 2 meses, comprobándose mediante la técnica de RT-PCR que se mantenía la expresión del clon de interés. 


\subsection{Congelación de células HEK-293}

A partir de un cultivo celular en fase exponencial, con un $80 \%$ de la superficie del flask cubierto se levantaron las células por pipeteo o con PBS EDTA 2mM y se centrifugaron a $750 \mathrm{~g}$ durante 10 min. Se decantó el sobrenadante y a continuación se resuspendieron en medio completo (DMEM suplementado con antibióticos, antifúngico, suero bovino fetal y L-Glutamina). La suspensión celular fue alicuotada en crioviales y se le añadió DMSO hasta una concentración del 5\%, se mezcló bien. Para conseguir una congelación progresiva se utilizó una cubeta de congelación. Esta cubeta consiste en una gradilla para crioviales que se acopla a un recipiente lleno de isopropanol el cual quedará bañando a los crioviales. Esta cubeta se introduce durante $24 \mathrm{~h}$ a $-80{ }^{\circ} \mathrm{C}$ y asegura una disminución de la temperatura progresiva. A continuación se pone a $-196{ }^{\circ} \mathrm{C}$ hasta su utilización. En los casos en los que no había disponible una cubeta de congelación las células se pusieron en hielo, a continuación se dejaron a $-20{ }^{\circ} \mathrm{C}$ durante al menos $1 \mathrm{~h}$. Una vez transcurrido este tiempo se pasaron a $-80{ }^{\circ} \mathrm{C}$, donde permanecieron toda la noche. Finalmente los crioviales se almacenaron indefinidamente a $-196^{\circ} \mathrm{C}$, en nitrógeno líquido.

\subsection{Descongelación de células HEK-293}

La descongelación de las células almacenadas en nitrógeno líquido al contrario que su congelación es un proceso rápido. Los crioviales se pasan directamente de $-196{ }^{\circ} \mathrm{C}$ a un baño a $37^{\circ} \mathrm{C}$. Inmediatamente tras la descongelación se añade medio para diluir la concentración de DMSO y que de esa forma no afecte a las células. Tras este paso se centrifugan a $750 \mathrm{~g}$ durante $10 \mathrm{~min}$. y el botón celular se resuspende en 
medio fresco completo y se siembra en un número de botellas que depende de la cantidad de células que se añadió a cada criovial.

\subsection{Obtención de membranas de células en cultivo}

Las células HEK-293 transfectadas de forma estable, se crecieron hasta alcanzar una confluencia del $80 \%$ en flask de $75 \mathrm{~cm}^{2}$ de superficie de crecimiento. Las células se despegaron de la botella incubando las mismas con PBS-EDTA 2 mM durante 5 min. a $37^{\circ} \mathrm{C}$. Tras despegarse se recogieron con pipeta y se centrifugaron en tubos estériles de $50 \mathrm{ml} \mathrm{a} 750 \mathrm{~g}$ durante $10 \mathrm{~min}$. a $4{ }^{\circ} \mathrm{C}$. Tras este paso se obtuvo el botón de las células deseadas. Seguidamente, las células se resuspendieron en un volumen de $\mathrm{PBS}\left(\mathrm{NaCl} 0.84 \mathrm{~g} ; \mathrm{KH}_{2} \mathrm{PO}_{4} 0.02 \mathrm{~g} ; \mathrm{Na}_{2} \mathrm{HPO}_{4} \cdot 2 \mathrm{H}_{2} \mathrm{O} 0.19 \mathrm{~g} ; \mathrm{KCl} 0.02\right.$ g; enrasar a $100 \mathrm{ml}$ y ajustar el $\mathrm{pH}$ a 7.4 con inhibidores de proteasas bacitracina 0.1 $\mathrm{mg} / \mathrm{ml}$, captopril $3.33 \mathrm{nM}$ y tiorfano $0.33 \mathrm{nM}$, todos de SIGMA) 20 veces inferior al volumen original de medio de cultivo, se homogeneizaron con un homogeneizador Brinkmann Polytron durante 30 segundos, a velocidad media y se centrifugaron a 1000 g durante 10 min. a $4{ }^{\circ} \mathrm{C}$. Tras aprovechar el sobrenadante, pasándolo a otro tubo, se repitió la misma operación con el botón obtenido y se juntaron los dos sobrenadantes desechando el botón, mayoritario en membranas nucleares. El conjunto de los sobrenadantes se centrifugó a $10^{5} \mathrm{~g}$ durante $1 \mathrm{~h}$ a $4{ }^{\circ} \mathrm{C}$ con el objetivo de sedimentar de un modo mayoritario las membranas celulares en las que se encuentran los receptores opioides. Tras la centrifugación se eliminó el sobrenadante y el botón se lavó con Tris-HCl 50 mM, pH 7.4 con inhibidores de proteasas (igual que en el PBS) y EDTA $1 \mathrm{mM}$ para eliminar los posibles restos del $\mathrm{Na}^{+}$procedente del PBS, ya que se ha demostrado que este ión inhibe la unión de ligandos opioides (agonistas). 
Finalmente, las membranas se resuspendieron en Tris- $\mathrm{HCl}(50 \mathrm{mM}, \mathrm{pH} 7.4$ con inhibidores de proteasas y EDTA $1 \mathrm{mM}$ ) hasta obtener una concentración final de proteína de 0.5-1 mg/ml, determinada por el método de Lowry (Lowry y cols., 1951) (Kit total protein, Sigma Diagnostics), utilizando albúmina sérica bovina (Sigma) como patrón.

\subsection{Ensayos de unión a saturación con radioligandos}

Los ensayos de unión a saturación nos permiten determinar los parámetros que definen la interacción de un ligando con una macromolécula. Dichos parámetros son la constante de disociación $\mathrm{K}_{\mathrm{d}}$, una medida de la afinidad, que se define como la concentración de ligando necesaria para ocupar la mitad de los sitios de unión y la población receptorial $\mathrm{B}_{\max }$ (de Bound maximum) que indica el número de sitios de unión en la muestra.

Los ensayos de saturación se realizaron utilizando extractos de membranas purificadas de células HEK-293, transfectadas de forma estable con el receptor zfMOR de pez cebra (a partir de colonias que expresaban el receptor, comprobado por RT-PCR). Los ensayos se llevaron a cabo utilizando $50 \mu \mathrm{g}$ de proteína. Las proteínas se incubaron con concentraciones crecientes de radioligando $\left({ }^{3} \mathrm{H}\right.$-Diprenorfina o ${ }^{3} \mathrm{H}$ DAMGO desde $0.156 \mathrm{nM}$ hasta 20-40 nM, concentración final) en un volumen final de $250 \mu \mathrm{l}$ en el siguiente tampón: Tris- $\mathrm{HCl} 50 \mathrm{mM}$ pH 7.4 con inhibidores de proteasas (bacitracina $0.1 \mathrm{mg} / \mathrm{ml}$, captopril $3.33 \mathrm{nM}$ y tiorfano $0.33 \mathrm{nM}$, Sigma). Tanto para estudiar la unión de ${ }^{3} \mathrm{H}$-Diprenorfina como la de ${ }^{3} \mathrm{H}$-DAMGO los ensayos se incubaron durante $60 \mathrm{~min}$. a $25^{\circ} \mathrm{C}$. 
En cada experimento, por cada concentración de radioligando se realizaron dos determinaciones: la unión total y la unión no específica. La unión total se define como la cantidad total de radioligando unido (esta unión puede ser de manera específica al receptor pero también hay unión no específica a otras proteínas de la muestra o al tubo). La unión no específica se define como aquella que sucede en presencia de una concentración saturante de ligando frío (en esa situación el radioligando solo estará unido de forma no específica a otros componentes de la reacción o al tubo). La unión específica la definiremos, por tanto, como la diferencia entre la unión total y la unión no específica. En el caso de receptores opioides la unión no específica se suele determinar utilizando naloxona no marcada (fría) a una concentración saturante de $10 \mu \mathrm{M}$.

Tras la incubación, la reacción se paró añadiendo 3 ml de tampón Tris-HCl 50 $\mathrm{mM}$ pH 7.4 a $4{ }^{\circ} \mathrm{C}$ y esta mezcla fue rápidamente filtrada al vacío en un Brandell Cell Harvester a través de filtros $G F / B$ (Schleichler \& Schuell) pretratados con polietilenimina (Sigma) al $0.2 \%$ (con el fin de minimizar la unión de ligando libre al filtro gracias a su carga positiva) durante al menos $60 \mathrm{~min}$. Antes de la filtración los filtros se lavaron con tres pases de $3 \mathrm{ml}$ de tampón Tris- $\mathrm{HCl}$ (50 mM, pH 7.4) atemperado a $4{ }^{\circ} \mathrm{C}$ para eliminar el exceso de polietilenimina. A continuación se procedió a filtrar las muestras seguido de dos lavados con el mismo tampón. Los filtros se depositaron en viales con $3.5 \mathrm{ml}$ de líquido de centelleo Ecosint A (National Diagnostics) y se incubaron durante al menos 16 h en agitación, La radiactividad se cuantificó con un contador de centelleo Beckman Coulter LS6500. Los ensayos se realizaron por duplicado y al menos 3 veces. 


\subsection{Ensayos de competición de ligandos por el receptor}

Los ensayos de competición o desplazamiento permiten conocer la afinidad que presentan ciertos ligandos por un receptor. Esta técnica es muy útil cuando no se dispone de los ligandos, cuya afinidad por el receptor se quiere conocer, en forma marcada. Para poder determinarlo se utiliza un ligando marcado, en nuestro caso mediante radiactividad, con una afinidad conocida por el receptor y se intenta desplazar la unión de dicho radioligando con distintas concentraciones del compuesto sin marcar. La capacidad de desplazamiento es un indicador de la afinidad del ligando sin marcar por el receptor. Los parámetros obtenidos de este tipo de experimentos son la dosis efectiva media o concentración inhibitoria media ( $\mathrm{IC}_{50}$ o $\mathrm{EC}_{50}$, según autores) que se define como la cantidad de ligando sin marcar necesario para desplazar el $50 \%$ de la unión específica del ligando marcado, y el porcentaje de desplazamiento. La $\mathrm{K}_{\mathrm{i}}$ o constante de inhibición es otro parámetro que mide la afinidad del ligando por el receptor y que se obtiene utilizando la ecuación de Cheng-Prusoff (Cheng y Prusoff, 1973). Mientras que el valor de $\mathrm{IC}_{50}$ varía en función de la concentración de ligando marcado utilizado el valor de $\mathrm{K}_{\mathrm{i}}$ es constante y por lo tanto permite una comparación mas exacta entre distintos experimentos.

Los ligandos sin marcar utilizados se disolvieron en agua destilada estéril y se realizaron alícuotas de $10 \mathrm{mM}, 500 \mu \mathrm{M}$ y $250 \mu \mathrm{M}$ que se conservaron a $-20{ }^{\circ} \mathrm{C}$. En el caso de los ligandos de tipo peptídico que pueden ser degradados con mayor facilidad se hicieron alícuotas de pequeños volúmenes para evitar en lo posible ciclos de congelación-descongelación. Para los ensayos de competición las proteínas (20 gㅡ) se incubaron con una concentración fija de radioligando $\left({ }^{3} \mathrm{H}\right.$-Diprenorfina o ${ }^{3} \mathrm{H}$ - 
DAMGO), aproximadamente en el rango de la $\mathrm{K}_{\mathrm{d}}$ del radioligando por el receptor, $\mathrm{y}$ concentraciones crecientes de ligando sin marcar (desde $10 \mathrm{pM}$ a $10 \mu \mathrm{M}$ o en el caso de la etorfina $0.1 \mathrm{pM}$ a $1 \mu \mathrm{M}$ ) en un volumen final de $250 \mu$ l en tampón de ensayo (HEPES $25 \mathrm{mM}$ pH 7.6, $50 \mathrm{mM} \mathrm{MgCl}_{2}, 0.32 \mathrm{M}$ sacarosa). La incubación fue de 90 min. a $25^{\circ} \mathrm{C}$. También se determinó la unión total (en ausencia del ligando frío o sin marcar) y la unión no específica (en presencia de naloxona $10 \mu \mathrm{M}$ ) para cada una de las concentraciones empleadas. Tras la incubación la reacción se filtró rápidamente con un FilterMate ${ }^{T m}$ harvester (Packard, Meriden, CT) a través de MultiScreen $_{H T S}$ FB 96-well filter plates (Millipore). Los filtros se lavaron dos veces con tampón HEPES $25 \mathrm{mM}$ pH 7.6 y a continuación se dejaron secar durante al menos 30 min. en vacío. A continuación se selló utilizando White seal MultiScreen Filtration System (Millipore) y se añadió a cada uno de los pocillos $30 \mu \mathrm{l}$ de líquido de centelleo Microscint ${ }^{\mathrm{TM}} 20$ (Perkin Elmer) posteriormente se cubrió la placa con Transparent seal (Millipore) y se incubó durante al menos 16 h. La radiactividad se cuantificó con un contador de centelleo Top Count $N X T^{T M}$ (Packard). Todos los experimentos se realizaron por triplicado y se repitieron al menos tres veces.

\subsection{Ensayos de actividad del receptor por $\left[{ }^{35}\right.$ S $]-G T P \gamma S$}

Para estudiar la actividad funcional de los receptores existentes en las membranas extraídas de las líneas celulares transfectadas con el receptor zfMOR de pez cebra utilizamos el ensayo de estimulación de la unión de $\left[{ }^{35} \mathrm{~S}\right]-\mathrm{GTP} \gamma \mathrm{S}$ (Traynor y Nahorsky, 1995). Este ensayo es una medida de la estimulación por el ligando de las proteínas G que interaccionan con el receptor; el $\left[{ }^{35} \mathrm{~S}\right]-\mathrm{GTP} \gamma \mathrm{S}$ es un análogo del GTP que se une al centro activo GTPásico de las proteínas G al igual que lo hace el GTP; 
sin embargo el enlace $\gamma$-tiofosfato es resistente a la hidrólisis por lo que se previene la recomposición de heterotrímero y se produce una acumulación de subunidades Ga marcadas de forma radiactiva. De esta manera, la cantidad de radiactividad unida será directamente proporcional al grado de activación de las proteínas G. Para realizar estos ensayos se emplean varias concentraciones de agonistas que provoquen la activación del receptor y, como resultado el intercambio en las proteínas $\mathrm{G}$ y su consiguiente activación. La actividad se determina como el porcentaje de activación específica respecto a la activación basal, la cual se define como la cantidad de radiactividad unida en ausencia de agonista. Al igual que en los experimentos de saturación y competencia también debemos calcular la unión no específica, en este caso se establece como unión no específica a la radiactividad unida en presencia de una concentración saturante de GTP $\gamma \mathrm{S}$ sin marcar $(10 \mu \mathrm{M})$. Los parámetros que podemos obtener en este tipo de ensayos son la dosis efectiva media o $\mathrm{EC}_{50}$, definida como la concentración de ligando necesaria para producir el $50 \%$ de la respuesta máxima. Este valor nos da una idea de la potencia del ligando. El otro parámetro es la activación máxima y este nos da una idea de la eficacia del ligando.

Para realizar este tipo de ensayos, las proteínas $(20 \mu \mathrm{g})$ se incubaron en un tampón de ensayo (Tris- $\mathrm{HCl} 50$ mM, $\mathrm{MgCl}_{2} 5$ mM, EDTA $1 \mathrm{mM}$ y $\mathrm{NaCl} 100 \mathrm{mM}$, pH 7.4) que además contenía BSA (0.1\%), DTT (1 mM), GDP $(10 \mu \mathrm{M}),\left[{ }^{35} \mathrm{~S}\right]-\mathrm{GTP} \gamma \mathrm{S}$ $0.1 \mathrm{nM}$, en presencia de distintas concentraciones de los ligandos opioides (desde 0.1 nM hasta $10 \mu \mathrm{M})$. La mezcla $(200 \mu \mathrm{l}$ de volumen final) se incubó durante 60 min. a $30{ }^{\circ} \mathrm{C}$, se paró añadiendo $4 \mathrm{ml}$ de Tris- $\mathrm{HCl} 50 \mathrm{mM}$ pH 7.4 a $4{ }^{\circ} \mathrm{C}$ y a continuación el $\left[{ }^{35} \mathrm{~S}\right] \mathrm{GTP} \gamma \mathrm{S}$ libre y unido se separó mediante filtración al vacío con un Brandell Cell Harvester a través de filtros $G F / B$ (Scheichler \& Schuell). Tras los lavados con tres 
pases de $3 \mathrm{ml}$ de tampón Tris- $\mathrm{HCl}(50 \mathrm{mM}, \mathrm{pH} 7.4)$ atemperado a $4{ }^{\circ} \mathrm{C}$ los filtros se depositaron en viales con $3.5 \mathrm{ml}$ de líquido de centelleo EcoScint A durante al menos 16 h en agitación, tras lo que se cuantificó la radiación mediante un contador de centelleo líquido Beckman LS6500. Todos los experimentos fueron realizados por triplicado y repetidos al menos 3 veces.

El porcentaje de estimulación de unión de $\left[{ }^{35} \mathrm{~S}\right] \mathrm{GTP} \gamma \mathrm{S}$ se calculó de la siguiente manera:

$$
\% \text { estimulación }=\frac{[d p m(\text { agonista })-d p m(\text { unión no específica })]}{[d p m(\text { basal })-d p m(\text { unión no específica })]-1} \times 100
$$

\subsection{Estudio de la inhibición de la adenilato ciclasa}

El estudio de los niveles de AMPc en las células HEK-293 que expresan de forma estable zfMOR se llevó a cabo mediante inmunoensayo. La inhibición de la actividad de la adenilato ciclasa estimulada por forscolina se realizó en presencia de varias concentraciones de ligando. Las células se crecieron en placas de 96 pocillos hasta una confluencia del $80 \%$. En el día del experimento, el medio de crecimiento se reemplazo por $100 \mu \mathrm{l}$ de medio de incubación consistente en $0.5 \mathrm{mM}$ isobutilmetilxantina (IBMX), $10 \mu \mathrm{M}$ forscolina, y varias concentraciones de ligandos (0.001 nM-10 $\mu \mathrm{M})$ en tampón Krebs-Ringer-HEPES ( $\mathrm{NaCl} 110$ mM, KCl 5mM, $\mathrm{MgCl}_{2} 1 \mathrm{mM}, \mathrm{CaCl}_{2} 1.8 \mathrm{mM}$, glucosa $25 \mathrm{mM}$, sacarosa $55 \mathrm{mM}$ y HEPES $10 \mathrm{mM}$ con un $\mathrm{pH}$ de 7.4). Las células se incubaron en un baño a $37^{\circ} \mathrm{C}$ durante $15 \mathrm{~min}$., previo sellado de la misma con HotSeal (Diversified Biotech, Boston, MA). A continuación la reacción fue terminada mediante incubación de las placas durante $7 \mathrm{~min}$. a 86-90 ${ }^{\circ} \mathrm{C}$ para así lisar las células y liberar el AMPc intracelular. El sobrenadante se recogió, 
tras una centrifugación en centrifuga de placas de microtítulo (Marathon 3000, Fisher scientific) a $500 \mathrm{~g}$ durante 5 min., para su medida tras al menos $1 \mathrm{~h} \mathrm{a} 4^{\circ} \mathrm{C}$.

Los niveles de AMPc se midieron mediante el Amplified Luminescent Proximity Homogeneus Assay AlphaScreen cAMP Detection Kit (BioSignal, Montreal. QC, Canadá) y utilizando una estación automatizada, Biomek 2000 Laboratory Automation Workstation (Beckman Coulter, Fullerton, CA). Para poder llevar a cabo la medición de los niveles de AMPc en primer lugar preparamos una curva estándar de AMPc sobre la cual poder extrapolar los valores obtenidos en las muestras. La curva estándar se prepara para cada uno de los experimentos y se compone de 16 concentraciones de AMPc comprendidas entre $0.1 \mathrm{mM}$ y $10 \mathrm{fM}$.

Medimos la cantidad de AMPc presente en $4 \mu \mathrm{l}$ del sobrenadante de cada uno de los pocillos mediante la utilización de "donor beads" recubiertas de streptavidina, “aceptor beads" recubiertas de anticuerpos frente a AMPc y AMPc biotinilado. En primer lugar las “donor beads" (concentración final $20 \mu \mathrm{g} / \mathrm{ml}$ ), las “aceptor beads" (concentración final $15 \mu \mathrm{g} / \mathrm{ml}$ ) y el AMPc biotinilado (concentración final $10 \mathrm{nM}$ ) se diluyeron en control buffer (2X para en el caso de las "donor beads" y $1 \mathrm{X}$ para las “aceptor beads") [HEPES 5 mM, pH 7,4; Tween20 0,3\% (60 \%); BSA 0,1\%; HBSS (solución salina Hanks) (40 \%)]. $4 \mu \mathrm{l}$ de "aceptor beads" y $4 \mu \mathrm{l}$ de sobrenadante de la reacción o $4 \mu \mathrm{l}$ del estándar de AMPc se pipetearon por duplicado en pocillos en una placa de 384 pocillos (Opti-plate; BD Falcon) utilizando para ello una estación de trabajo Biomek 2000 (Beckman Coulter) en un ambiente de luz tenue y manteniendo la estación de trabajo a $4{ }^{\circ} \mathrm{C}$. La placa se selló utilizando TopSeal adhesive sealing film (PerkinElmer Life and Analitical Sciences) y se incubó en oscuridad durante dos 
horas. Pasadas las dos horas se retiró el TopSeal, se añadieron $12 \mu \mathrm{l}$ de "donor beads" a cada uno de los pocillos y se volvió a sellar y se incubó durante 18-24 h en oscuridad y a $4{ }^{\circ} \mathrm{C}$. A continuación, tras equilibrar a temperatura ambiente y en oscuridad durante $4 \mathrm{~h}$ el contenido de AMPc de cada uno de los pocillos se determinó excitando las "donor beads" a $680 \mathrm{~nm}$, lo que genera un singlete de $\mathrm{O}_{2}$ y que resulta en la emisión del "aceptor beads" a 520-620 nm. La fluorescencia de los pocillos se cuantificó con un lector de placas Fusion $\alpha$ (Packard) y la cantidad de AMPc en cada muestra se extrapoló a la curva estándar de AMPc.

En aquellos experimentos en los que se utilizó toxina pertúsica (List Biological Laboratorios INC., Campbell, CA) 100 ng/ml PTX se añadieron al medio de cultivo 6 horas antes de llevar a cabo el ensayo de AMPc. En los experimentos en los que se utilizó un antagonista junto con la etorfina las concentraciones fueron de 1 $\mu \mathrm{M}$ para $\beta$ FNA y naloxona y $1 \mathrm{nM}$ para la diprenorfina.

\subsection{Análisis de los datos}

En los ensayos de unión al receptor y de competición la unión específica se determinó como la diferencia entre la unión total y la unión inespecífica (en presencia del ligando frío $10 \mu \mathrm{M})$. Para el análisis de los datos hemos utilizado el programa Graphpad Prism 4.0 (San Diego, CA) que realiza análisis de regresión no lineal. Este programa utiliza ecuaciones que se ajustan a diferentes modelos. Así, el ajuste de los puntos siguiendo el modelo de un sitio de unión frente al que predice dos o más se evaluó mediante un "test F" que determina si los parámetros ajustables mejoran los datos para acoplarlos al modelo sencillo de un sitio de unión o al más complejo de dos 
o más. Se calcularon los valores de $\mathrm{K}_{\mathrm{d}}$ (constantes de disociación, en $\mathrm{nM}$ ) y $\mathrm{B}_{\max }$ (concentración de proteína receptorial en fmol/mg de proteína) obtenidos en los diferentes ensayos llevados a cabo. Los valores de $\mathrm{EC}_{50}$ (concentración de agonista que ocupa el $50 \%$ de los sitios de unión), determinados originalmente mediante el método de regresión no lineal de los mínimos cuadrados a partir de del logaritmo de la concentración del ligando desplazante fueron después convertidos a valores de $\mathrm{K}_{\mathrm{i}}$ (constantes de inhibición de la unión del ligando tritiado por el ligando frío que desplaza) utilizando el método de Cheng y Prusoff (1973).

\subsection{Estudios de inmunofluorescencia}

Una forma cualitativa de determinar los procesos de internalización de un receptor de membrana es mediante técnicas de inmunofluorescencia. Los estudios de inmunofluorescencia se llevaron a cabo utilizando las células HEK-293 que expresan de forma estable el receptor zfMOR y células HEK-293 que expresaban de forma estable el receptor mu de rata. Estas últimas nos proporcionan un control positivo interno. Ambos receptores presentan en su extremo amino terminal la secuencia antigénica HA para su fácil detección. Para ello, las células se crecieron sobre cubreobjetos circulares de $1 \mathrm{~cm}$ de diámetro previamente polilisinados. Para polilisinar los cubreobjetos primeramente se sometieron a un tratamiento de limpiado utilizando una solución de etanol $70 \%$ y ácido clorhídrico 1\%. Tras un periodo mínimo de $1 \mathrm{~h}$ los cubreobjetos se lavaron muy bien con agua destilada para eliminar cualquier traza de etanol o ácido, se autoclavaron y posteriormente secaron en una estufa. Una vez secos se cubrieron con una solución comercial de polilisina $0.01 \%$ (Sigma) durante al menos 15 minutos, a continuación, se eliminó la polilisina y los 
cubreobjetos se dejaron secar al aire. Posteriormente se lavaron 3 veces con PBS estéril seguido de un lavado con medio de cultivo. Por último los cubreobjetos se depositaron en placas multipocillo de 12 ( 2 cubres por pocillo) o de 24 ( 1 cubre por pocillo). Las células crecidas en botellas con un 70-80 \% de confluencia se levantaron utilizando PBS EDTA 2mM, se centrifugaron a $500 \mathrm{~g}$ durante $5 \mathrm{~min}$. y se resuspendieron en medio de cultivo. En cada pocillo se añadieron $2 \mathrm{ml}$ de medio de cultivo completo y un volumen de células que varía en función de cuando se fuese a realizar el experimento.

El día del experimento las células debían presentar una confluencia del 60-70 \% para intentar evitar la agregación celular en forma de película o lámina sobre el cubreobjetos. La dilución del ligando se preparó utilizando DMEM completo + 30 mM HEPES pH 7.4. El HEPES nos va a asegurar un pH constante a lo largo del experimento. De esta forma, se aspiró el medio de los pocillos y se añadió el medio fresco con la droga a una concentración final $1 \mu \mathrm{M}$, siempre manteniendo pocillos control los que no se le añade droga alguna. Posteriormente la placa se incubó 30 min. a $37{ }^{\circ} \mathrm{C}, 5 \% \mathrm{CO}_{2}$. Transcurrido el tiempo de incubación la placa se depositó directamente sobre hielo, de manera que se paran los procesos de internalización y reciclaje del receptor. Tras retirar el medio las células se lavaron con PBS enfriado a 4 ${ }^{\circ} \mathrm{C}$ y se fijaron con paraformaldehído (Sigma) al $4 \%$ en PBS durante 15 min. en hielo. El empleo de paraformaldehído como fijador permite una buena preservación de la estructura de las membranas celulares, lo que es fundamental para el estudio de receptores de membrana. Tras realizar un lavado con PBS, las células se permeabilizaron con Tween20 (Sigma) al $0.2 \%$ en PBS y durante 10 min. en hielo. Este paso es fundamental ya que nos interesa ver tanto la fluorescencia presente en la 
membrana como aquella que se encuentra vesículas en el citoplasma como consecuencia de los procesos de internalización tras el tratamiento. Tras lavar el cubreobjetos con PBS se depositaron en cámaras húmedas para realizar la tinción inmunofluorescente. El anticuerpo utilizado fue un anticuerpo monoclonal anti-HA directamente conjugado con fluoresceína obtenido en rata (Roche); éste se diluyó en medio completo + $30 \mathrm{mM}$ HEPES $\mathrm{pH} 7.4$ a una concentración de $5 \mu \mathrm{g} / \mathrm{ml}$ y se emplearon $30 \mu \mathrm{l}$ de dilución de anticuerpo para cubrir la superficie de cada uno de los cubreobjetos. Esta incubación se llevó a cabo en la cámara húmeda durante 30 min. a $4{ }^{\circ} \mathrm{C}$ y en oscuridad. Finalizado el tiempo de incubación se realizaron 3 lavados con tampón de lavado (PBS $+2 \%$ suero bovino fetal $+0.05 \% \mathrm{NaN}_{3}$ ) en oscuridad. A continuación se sumergieron en una solución de Hoechst $2 \mu \mathrm{M}$ (Invitrogen) durante 2 s y finalmente las preparaciones se montaron sobre portaobjetos con medio de montaje para muestras fluorescentes (Dako Cytomation). Las muestras se dejaron secar 2-3 h a temperatura ambiente y se guardaron a $4{ }^{\circ} \mathrm{C}$ en oscuridad hasta su estudio en el microscopio.

Las muestras se observaron en un microscopio Axiovert 200M de Carl Zeiss, utilizando el objetivo 63x para tomar las fotografías (Cámara AxioCam) y con filtros para Alexa 488 y DAPI. Las fotografías tomadas se analizaron con el programa AxioVision LE.

\subsection{Estudios de citometría de flujo}

Para poder cuantificar los niveles de internalización del receptor una de las técnicas más adecuadas es la citometría de flujo. Para ello utilizamos un anticuerpo 
que reconoce un epítopo antigénico, en nuestro caso HA y que porta un fluorocromo. Para realizar estos ensayos las células se crecieron en botellas o flask de $25 \mathrm{~cm}^{2}$ de superficie de crecimiento, de forma que el día del experimento presentaran una confluencia del 70-80\%. No es conveniente que el crecimiento celular llegue a un 100 \% de confluencia ya que tienen lugar fenómenos de inhibición del crecimiento y se produce una disminución de los niveles del receptor en la membrana plasmática. El día del experimento se retira el medio de cultivo y se añade la droga diluida en medio completo + 30 mM HEPES pH 7.4, dejándolo incubar un tiempo que dependerá del experimento a realizar. Tras la incubación las botellas se depositaron en hielo para parar los procesos de internalización y las células se levantaron utilizando PBS EDTA $2 \mathrm{mM}$. Posteriormente las células se centrifugaron a $500 \mathrm{~g}$ durante $5 \mathrm{~min}$. y a $4{ }^{\circ} \mathrm{C}$ y se resuspendieron en un volumen de $80 \mu \mathrm{l}$ de medio completo + 30 mM HEPES pH 7.4. $20 \mu \mathrm{l}$ de suspensión celular se incubaron en un tubo eppendorf con $20 \mu \mathrm{l}$ de una dilución del anticuerpo para obtener una concentración final de $5 \mu \mathrm{g} / \mathrm{ml}$. El anticuerpo empleado fue un anticuerpo de rata que reconoce al antígeno HA y que está directamente conjugado con fluoresceína (Roche). El anticuerpo se incubó durante 30 min. en oscuridad y a $4{ }^{\circ} \mathrm{C}$. Transcurrido este tiempo se centrifugaron los tubos a 500 g y $4{ }^{\circ} \mathrm{C}$ durante 5 min., se aspiró el sobrenadante y el botón celular se lavó tres veces con tampón de lavado (PBS $+2 \%$ suero bovino fetal $+0.05 \% \mathrm{NaN}_{3}$ ) enfriado a $4{ }^{\circ} \mathrm{C}$. Finalmente el botón celular se resuspendió en $500 \mu \mathrm{l}$ de PBS EDTA 2 mM y se transfirió a tubos de poliestireno de $5 \mathrm{ml}$ (Fisherbrand). Los tubos se taparon con papel de aluminio para protegerlos de la luz y se guardaron a $4{ }^{\circ} \mathrm{C}$ hasta el momento de la adquisición en el citómetro. En los casos en los que no se pudiera pasar la muestra por el citómetro el mismo día del experimento se realizó una fijación de las células mediante paraformaldehído $2 \%, 10 \mathrm{~min}$. en hielo tras los lavados del 
anticuerpo. A continuación se lavó de nuevo y se resuspendió en PBS EDTA 2 mM como en el caso anterior.

Junto con los tratamientos se realizaron dos tipos de controles: el control positivo, en ausencia de ligando, determina los niveles basales de receptor en la membrana plasmática; el control negativo, en ausencia de anticuerpo, nos indica la autofluorescencia de la muestra. Además como un control interno de la técnica se utilizó el receptor opioide mu de rata transfectado en células HEK-293 del cual se conocen los niveles de internalización.

Las muestras se analizaron en un citómetro FACScalibur (Becton \& Dickinson) bajo los siguientes parámetros: FSC (Forward Scatter, que determina el tamaño celular) y SSC (Side Scatter, que determina la granularidad interna o complejidad de la partícula) en escala lineal, y la fluorescencia, FL1, en la escala logarítmica. En la adquisición de las células por el citómetro se dibujó una ventana o gate en torno a las células vivas y se adquirieron 10000 eventos por tubo. A continuación se determinó, en primer lugar, la fluorescencia producida por las células sin teñir, seguido por los controles y los tratamientos. Los datos se analizaron con el programa CellQuest (Becton \& Dickinson). El porcentaje de internalización se calculó como:

$\%$ internalización $=100-\left[\frac{[G M(\text { Tratamiento })-G M(\text { Control } \sin \text { anticuerpo })]}{[G M(\text { Control } \sin \text { tratamiento })-G M(\text { Control } \sin \text { anticuerpo })]} \times 100\right]$

Siendo GM la media Geométrica (Geomean) de la curva de fluorescencia. 

Resultados 

Es indudable que conocer las bases moleculares de la actividad de los agentes opioides endógenos abre una puerta al desarrollo de nuevos fármacos analgésicos. En este trabajo hemos caracterizado la actividad del receptor opioide mu de pez cebra obteniendo datos que nos llevan a reconocer al pez cebra como un buen modelo para el estudio del sistema opioide.

\subsection{Estudio de la expresión de zfMOR en el pez cebra}

En nuestra primera aproximación al objetivo que nos planteamos, quisimos determinar si la expresión del receptor zfMOR se encuentra restringida al sistema nervioso o se localiza en otras áreas del pez cebra. Para ello llevamos a cabo PCRs utilizando como molde cDNA obtenido a partir de RNA de distintos órganos del pez cebra. Como se observa en la figura 26 podemos detectar expresión en cerebro, retina, corazón, hígado y sangre. En agallas se puede intuir una banda del tamaño adecuado. En músculo e intestino no se detecta expresión.

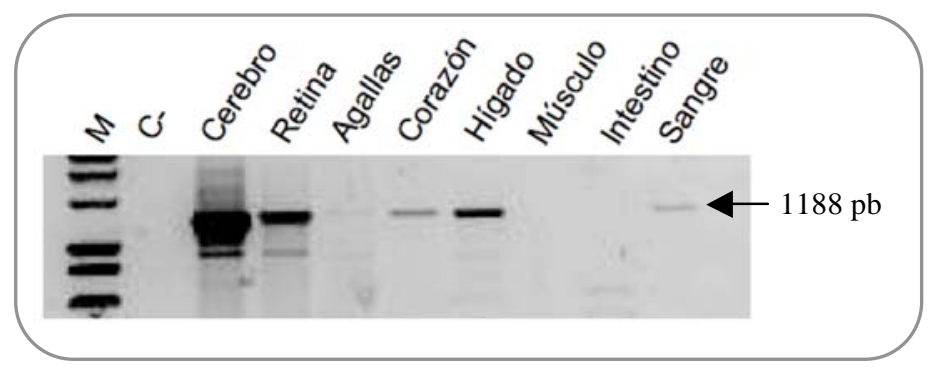

Figura 26: Productos de PCR, separados en un gel de agarosa, correspondientes a la expresión del receptor zfMOR en distintos tejidos del pez cebra. 


\subsection{Obtención de la construcción de zfMOR}

Para poder llevar a cabo el estudio del receptor zfMOR requerimos un sistema en el que poder analizarlo de forma aislada. Está bien establecido que la línea celular HEK-293 (Human Embryonic Kidney) no expresa ningún tipo de receptor opioide (Arden y cols., 1995) pero sí proteínas implicadas en la transducción de sus señales intracelulares, como proteínas G, adenilato ciclasas, etc. Dado que es un sistema bien establecido nos propusimos llevar a cabo la expresión de zfMOR en esta línea celular.

En primer lugar obtuvimos el cDNA (DNA copia de RNA) correspondiente a la fase de lectura abierta u ORF (Open Reading Frame) del gen zfMOR. Para ello se extrajo RNA total a partir de cerebros de pez cebra adultos y se llevo a cabo la retrotranscripción del mismo utilizando como cebador un oligonucleótido de restos de desoxitimidinas (OligodT). De esta manera conseguimos un híbrido DNA-RNA sobre el que, posteriormente, realizamos una PCR utilizando oligonucleótidos específicos para la amplificación de la ORF de zfMOR. Como norma general previo a la amplificación del fragmento de interés se lleva a cabo un control positivo para determinar la viabilidad de la retrotranscripción. En nuestro caso el control positivo utilizado es parte de la ORF de zfDOR1, el cual hemos demostrado previamente que se expresa de forma abundante en el cerebro de pez cebra (Barrallo y cols., 1998a; Porteros y cols., 1999). Una vez realizada la RT-PCR los productos se sometieron a una electroforesis en gel de agarosa al $0.8 \%$ lo que nos permitió comprobar su tamaño y la ausencia de contaminaciones o amplificaciones inespecíficas. (Figura 27) 


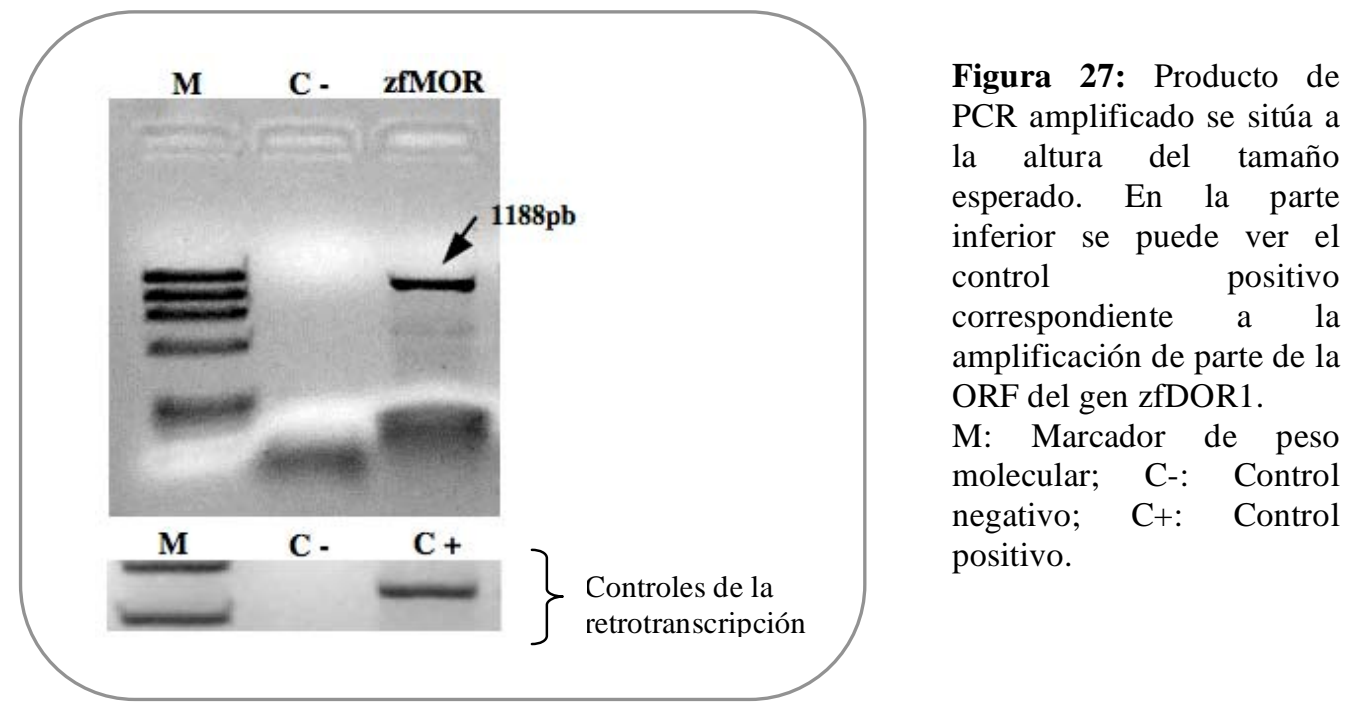

Como se observa en la fotografía del gel (Figura 27) obtuvimos una única banda cuyo patrón de migración se ajusta al tamaño esperado 1188 pares de bases. La banda estaba bien definida lo cual facilita y mejora su purificación a partir del gel, ya que se minimiza la cantidad de agarosa que hay que recortar. Esta purificación se podría realizar a partir del producto de PCR siempre que se esté seguro de que la reacción ha tenido lugar correctamente. En nuestro caso optamos por someter primero al producto de PCR a electroforesis ya que en este proceso podemos estar separando moléculas de DNA que se hayan amplificado de forma inespecífica y que estén en una concentración tan baja que no se aprecien en el gel tras someterlo a luz ultravioleta. Además, por lo menos en algunos casos, la purificación de bandas a partir de geles de agarosa es ventajosa frente a la purificación directa de la PCR ya que permite la eliminación de sales que pudieran interferir en pasos posteriores y para la eliminación de los oligonucleótidos que hayan quedado en exceso.

Tras la purificación de la banda del gel de agarosa, se sometió a electroforesis una alícuota de la misma de $4 \mu \mathrm{l}$ para comprobar su intensidad, lo que nos da una idea de la concentración a la que se encuentra. (Figura 28) 


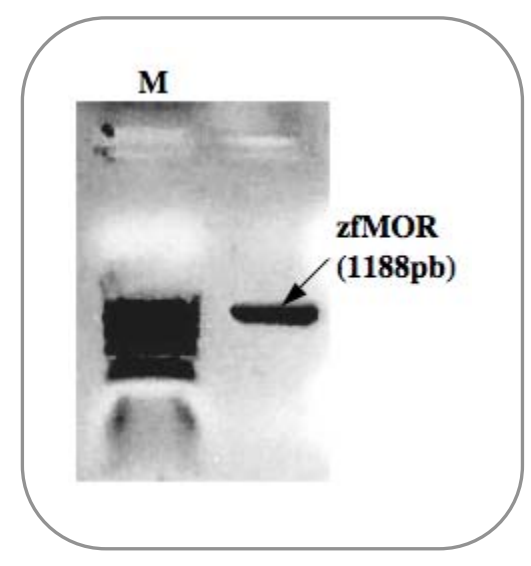

Figura 28: Purificación de la banda amplificada de zfMOR. Esta electroforesis nos permite hacernos una idea de la concentración a la que se encuentra nuestro cDNA. M: Marcador de peso molecular.

El siguiente paso, para la obtención de una construcción que nos permita la expresión de zfMOR en células animales, es introducir el cDNA correspondiente a la ORF de zfMOR en un vector de clonación. Un vector de clonación se puede definir como una pequeña molécula de DNA con capacidad de autoreplicarse que se puede introducir en una célula, procariota o eucariota, y en cuya secuencia se puede integrar el gen o secuencia de interés. El vector utilizado fue el pGEM $^{\circledR}-\mathrm{T}$ Easy. La gran ventaja de este plásmido es que está diseñado para la rápida ligación de productos de PCR. Algunas de las polimerasas termoestables más utilizadas en las reacciones de PCR (por ejemplo Taq, Tfl y Tth) tienen la característica de que añaden desoxiadenosinas terminales en los extremos 3' de los productos de PCR (Clark, 1998; Newton y cols, 1994); este hecho se ha aprovechado generando plásmidos que tienen desoxitimidinas terminales de forma que se crean extremos cohesivos.

Tras la unión o ligación del plásmido con el cDNA correspondiente a la ORF de zfMOR se procedió a la transformación (introducción de DNA exógeno en bacterias) de bacterias súper competentes para, posteriormente, analizar las colonias formadas en busca de nuestro inserto (la denominación de súper competentes hace 
referencia a su gran capacidad de adquirir DNA exógeno del medio). Otra ventaja que posee el plásmido utilizado es que no sólo permite la selección de las bacterias transformadas sino que permite la distinción entre aquellas que además poseen el inserto de interés.

Cuando se lleva a cabo la ligación de las moléculas de DNA, la efectividad de la misma depende de la temperatura y tiempo en el que se realice, del grado de pureza del DNA, de la calidad de las enzimas utilizadas, etc. Aún en condiciones óptimas es muy difícil asegurar que todas las moléculas de DNA hayan sido unidas, lo que hemos tenido en cuenta en nuestra ligación. En ocasiones tenemos plásmidos cuyos extremos se unen entre sí en vez de con el fragmento de PCR (se autoligan); por tanto se pueden tener bacterias transformadas con ese tipo de plásmidos. El plásmido utilizado posee un sistema para poder diferenciar entre bacterias que tienen el inserto y aquellas que no lo tienen, mediante un sistema de coloración. Cuando el plásmido no tiene inserto el gen de la $\beta$-galactosidasa contenido en su secuencia está completo por lo que se va a transcribir y posteriormente traducir originando una proteína funcional que en presencia de un sustrato, el X-Gal, y un inductor, el IPTG, proporciona a las bacterias una tonalidad azulada. Por el contrario, cuando el plásmido tiene el inserto el gen de la $\beta$-galactosidasa queda interrumpido por lo que no se sintetizará la proteína y las bacterias no tendrán coloración (Figura 29). 


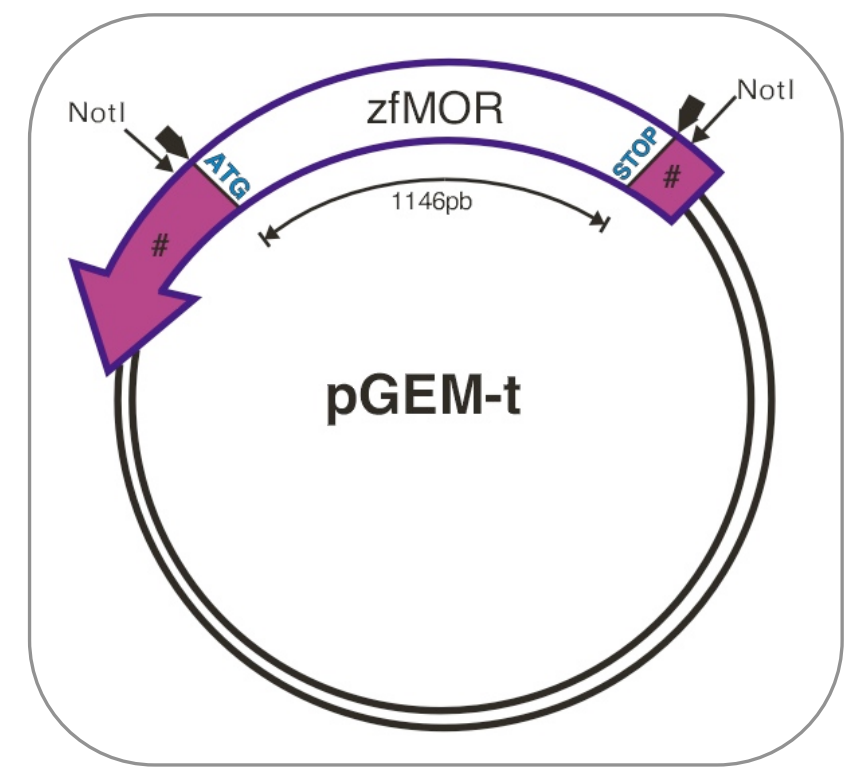

Figura 29: Esquema del vector de clonación pGEM $^{\circledR}-\mathrm{T}$ Easy con nuestra secuencia insertada. La flecha morada se corresponde con el gen de la $\beta$-galactosidasa que al quedar interrumpido no podrá transcribirse y por tanto las bacterias que tengan esta construcción no serán capaces de degradar el X-Gal del medio y serán de color blanco. Se resaltan también los sitios de corte de la enzima NotI y EcoRI que van a ser importantes para los pasos siguientes. Nótese que en este plásmido no importa en que sentido se inserte nuestra secuencia ya que no necesitamos que las bacterias transcriban el la ORF de zfMOR.

De las colonias blancas obtenidas tras la transformación se seleccionaron al azar entre 6 y 10 y se llevó a cabo la extracción y purificación de los plásmidos que contenían. El análisis posterior mediante enzimas de restricción nos confirmó que el tamaño del inserto es el correcto. (Figura 30)

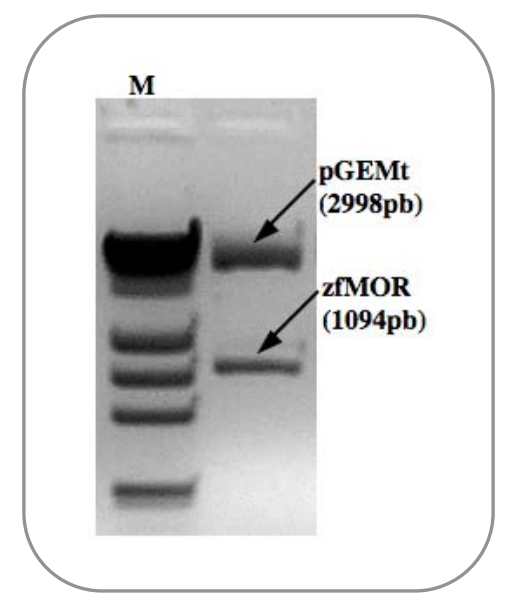

Figura 30: En la fotografía del gel se pueden observar dos bandas, una superior correspondiente al plásmido y la inferior a zfMOR. La banda correspondiente a zfMOR es ligeramente más baja ya que zfMOR presenta un sitio de corte para la enzima EcoRI en su extremo 3'.

La enzima de restricción utilizada para la digestión del plásmido fue EcoRI. Esta enzima presenta dos sitios de corte situadas en el sitio de clonaje múltiple o MCS (Multiple Cloning Site), y otro más en la región 3' de zfMOR (posición 1087). Estos 
tres sitios de corte nos producen tres fragmentos tras la digestión; el plásmido, zfMOR truncado en su extremo 3' y un pequeño fragmento que no se puede visualizar en geles de agarosa de tan baja concentración. La razón de utilizar la enzima EcoRI para llevar a cabo la comprobación y no utilizar otra que solo corte en el MCS del plásmido, como NotI, que nos daría únicamente dos productos de corte, ya que no obtenemos más información que con EcoRI. Una vez confirmado mediante el análisis de restricción que el tamaño del inserto era el correcto se procedió a la secuenciación del mismo en el servicio de secuenciación de la Universidad de Salamanca para así corroborar que la secuencia no había sufrido cambios o mutaciones en los pasos realizados.

Tras el análisis de las secuencias se procedió a la escisión del inserto del plásmido pGEM $^{\circledR}$-T Easy. Para llevar a cabo esta digestión se utilizó una enzima que cortara dos veces en el Sitio de Clonaje Múltiple del plásmido y que a su vez no corte en la secuencia de zfMOR. La enzima de restricción seleccionada fue NotI ya que cumple esas dos condiciones. Otra opción habría sido la utilización de dos enzimas distintas, que cortaran cada una a un lado de nuestra secuencia, sin embargo se optó por no utilizar digestiones múltiples ya que suelen dar más problemas que las sencillas.

Una vez separados los productos de la digestión en un gel de agarosa se purificó el inserto al igual que en el caso de la PCR inicial, para posteriormente subclonarlo en el plásmido de expresión eucariota pcDNA3.1. Este plásmido nos permite que el inserto sea transcrito en nuestro sistema de expresión, las células HEK293. 
Un paso previo a la ligación del plásmido y el inserto es la propia preparación del plásmido. Éste debe que ser digerido con la misma enzima con la que se digirió pGEM $^{\circledR}$-T Easy, para que de esta forma el plásmido y el inserto puedan unirse mediante la complementariedad de bases en los sitios de corte. Tras la digestión del plásmido éste se purifica y desfosfata para evitar el máximo la autoligación de los extremos. A continuación se puede realizar la ligación y la posterior transformación, las cuales se levaron a cabo como en el caso de GEMM $^{\circledR}-\mathrm{T}$ Easy. El análisis de las colonias transformadas mediante diferencias en coloración no es posible en este caso ya que el plásmido pcDNA3.1 no presenta el gen de la $\beta$-galactosidasa. Para poder determinar que colonias tenían plásmido con inserto o sin él se hizo una extracción y purificación seguida de un estudio con enzimas de restricción. Puesto que en este caso se trata de un vector de expresión es muy importante tener en cuenta que éste no solo ha de tener el inserto, sino que este se tiene que encontrar bien orientado para que pueda transcribirse (Figura 31).

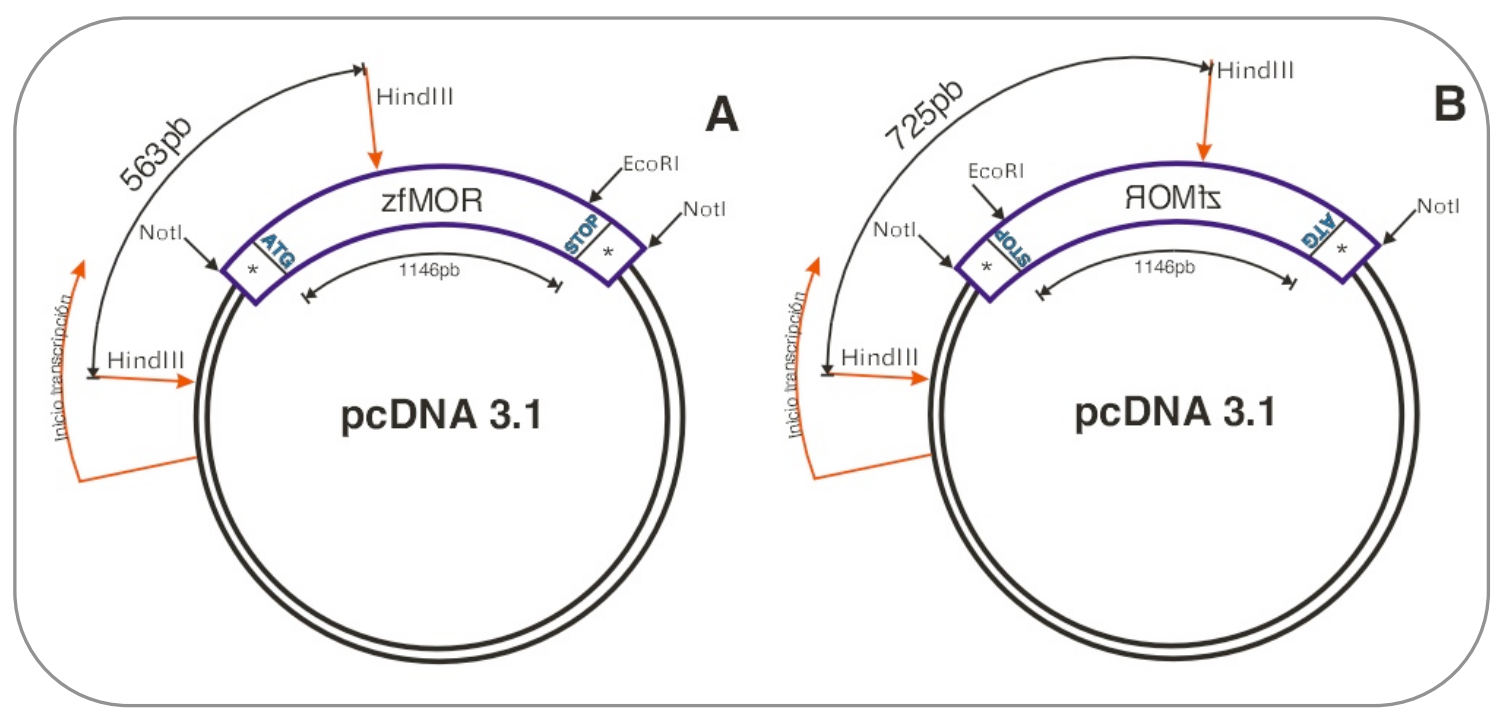

Figura 31: Estudio previo a la digestión. En primer lugar se seleccionó una enzima adecuada y posteriormente se determinó el patrón de digestión. A: se muestra a zfMOR insertado de forma correcta y que por tanto podrá transcribirse. B: zfMOR insertado al revés; en este caso no es posible la transcripción de zfMOR. 
El análisis de restricción se realizó utilizando la enzima HindIII. Esta enzima presenta un sitio de corte en el plásmido y otro dentro de la secuencia de zfMOR (Figura 31). El hecho de que el sitio de corte en zfMOR no sea central sino que esté desplazado hacia un extremo de la secuencia va a permitir la distinción de la orientación. En nuestro caso obtendremos distintos tamaños, en función de la orientación, tras la digestión apropiada. Cuando se inserta de forma correcta los dos sitios de corte se sitúan a una distancia de 608 pares de bases (Figura 31A) mientras que cuando se inserta al revés los sitios de corte para HindIII quedan separados 768 pares de bases (Figura 31B). Esta diferencia en tamaños es más que suficiente para poder diferenciarlos en un gel de agarosa al $1 \%$. Este sistema es el que utilizaremos para diferenciar entre los plásmidos sin inserto y los que lo tienen bien o mal orientado.

Tras someter a los productos de digestión a una electroforesis en un gel de agarosa al $1 \%$ se visualizaron los fragmentos en un transiluminador de luz ultravioleta (Figura 32).

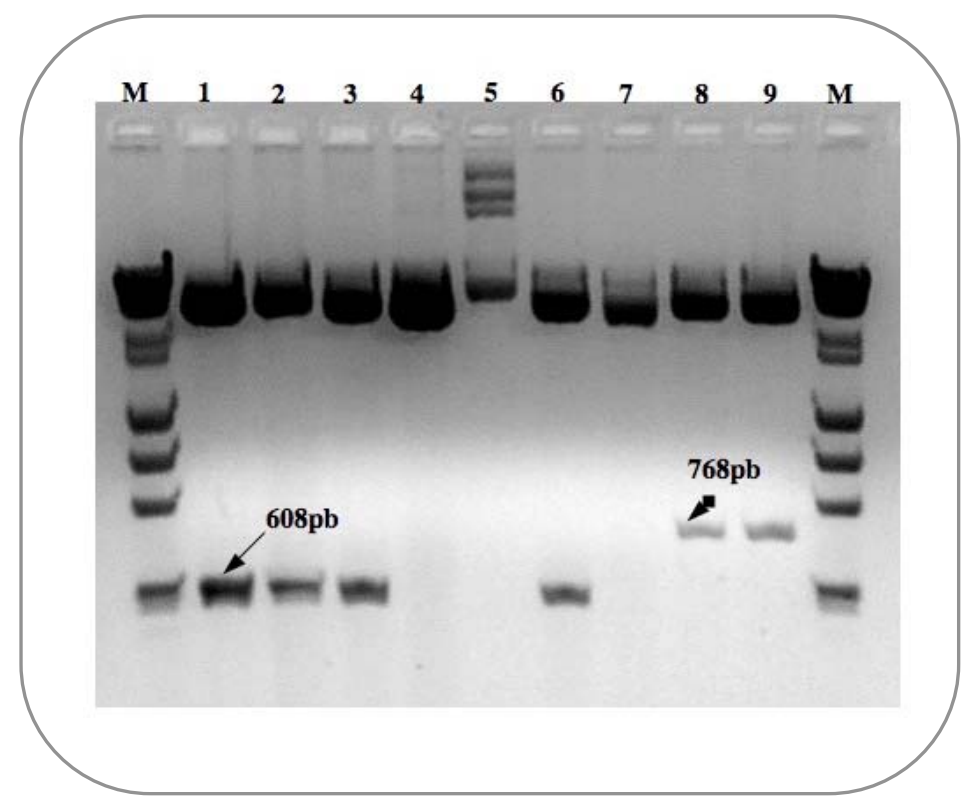

Figura 32: Electroforesis correspondiente a la digestión de la construcción. Los carriles $1,2,3$ y 6 se corresponden con insertos bien orientados, ya que obtenemos una banda a la altura correspondiente a las $608 \mathrm{pb}$. Los carriles 4 y 7 se corresponden con plásmidos sin inserto y los carriles 8 y 9 serían insertos orientados al revés (banda de 768 pares de bases). El carril 5 tiene el patrón característico de un plásmido no digerido que migra formando varias bandas como consecuencia de los distintos grados de enrollamiento que puede adoptar (estructuras secundarias). 
Una vez analizado el patrón de digestión, aquellos plásmidos que cumplían con los tamaños predichos y por tanto poseían el inserto en la orientación correcta se mandaron a secuenciar para comprobar que no se había producido ningún cambio en el inserto durante su replicación en las bacterias. Tras esta comprobación se pudo pasar a la transfección de nuestra construcción en las células HEK-293.

\subsection{Transfección de la construcción en células HEK-293}

La transfección de la construcción con zfMOR se llevó a cabo siguiendo el método descrito en el capítulo de Material y Métodos.

Tras la transfección se deben seleccionar aquellas células que realmente han adquirido el plásmido, ya que la eficacia de la transfección no es del 100\%. Las células son seleccionadas mediante la utilización de un antibiótico, G-418 (neomicina), ya que el plásmido pcDNA3.1 contiene un gen cuya proteína codificada confiere resistencia a dicho compuesto. De esta forma todas aquellas células que contengan el plásmido serán capaces de crecer en un medio con el antibiótico. Además de esta selección es necesario hacer un control mediante la utilización de RTPCR sobre RNA extraído de las células transfectadas en crecimiento. Esta prueba nos permite determinar que las células han incorporado la construcción y que además se esta llevando a cabo la trascripción del gen de interés, zfMOR. El producto de la RTPCR se separó en un gel de agarosa para su visualización (Figura 33). En este caso podemos observar que obtenemos expresión de zfMOR y los controles positivos (GAPDH humana) y negativos nos indican que la técnica se ha llevado a cabo de forma correcta. 


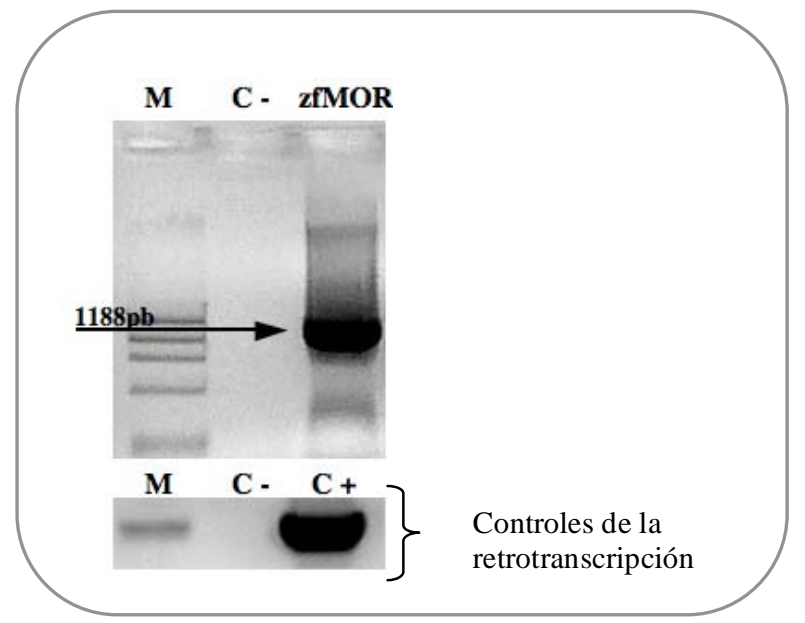

Figura 33: Producto de PCR amplificado a partir del cDNA de las células HEK-293 que expresan zfMOR; Su tamaño coincide con el tamaño esperado. En la parte inferior está el control positivo del cDNA, la GAPDH y su el control negativo en el que se realiza la retrotranscripción sin presencia de RNA.

M: Marcador de peso molecular;

C-: Control negativo;

$\mathrm{C}+$ : Control positivo.

\subsection{Prueba de la presencia del receptor zfMOR en las células HEK293}

Tras un periodo de selección que oscila entre uno y dos meses se considera que las células han quedado transfectadas de forma estable, es decir el DNA introducido ha quedado integrado en el genoma de la célula, por lo que se podrá empezar a analizar la actividad del receptor. Existe también la posibilidad de utilizar células transfectadas de forma transitoria (transient), sin embargo esto hace que los resultados sean más variables como consecuencia de los distintos grados o niveles de expresión que se pueden obtener en cada transfección.

Tras conseguir una línea celular que expresa de forma estable el receptor zfMOR lo primero que debíamos comprobar es que el receptor es capaz de unir ligandos opioides y que esa unión es desplazada por el antagonista opioide naloxona. Para conseguir este fin determinamos la capacidad de unión de ${ }^{3} \mathrm{H}$-diprenorfina, un ligando opioide no selectivo, a zfMOR. Se siguió el protocolo expuesto en el capítulo Material y Métodos pero utilizando únicamente una concentración del compuesto radiactivo, lo cual es suficiente para obtener la información deseada. Otra diferencia es que se utilizaron células del cultivo resuspendidas en el tampón de reacción en 
lugar de los extractos proteicos purificados; esto permite llevar a cabo el experimento más rápidamente y con mayor número de muestras sin perder ningún tipo de información. Utilizando este método se pudieron seleccionar aquellas colonias con mayor capacidad de unión del ligando (Figura 34).

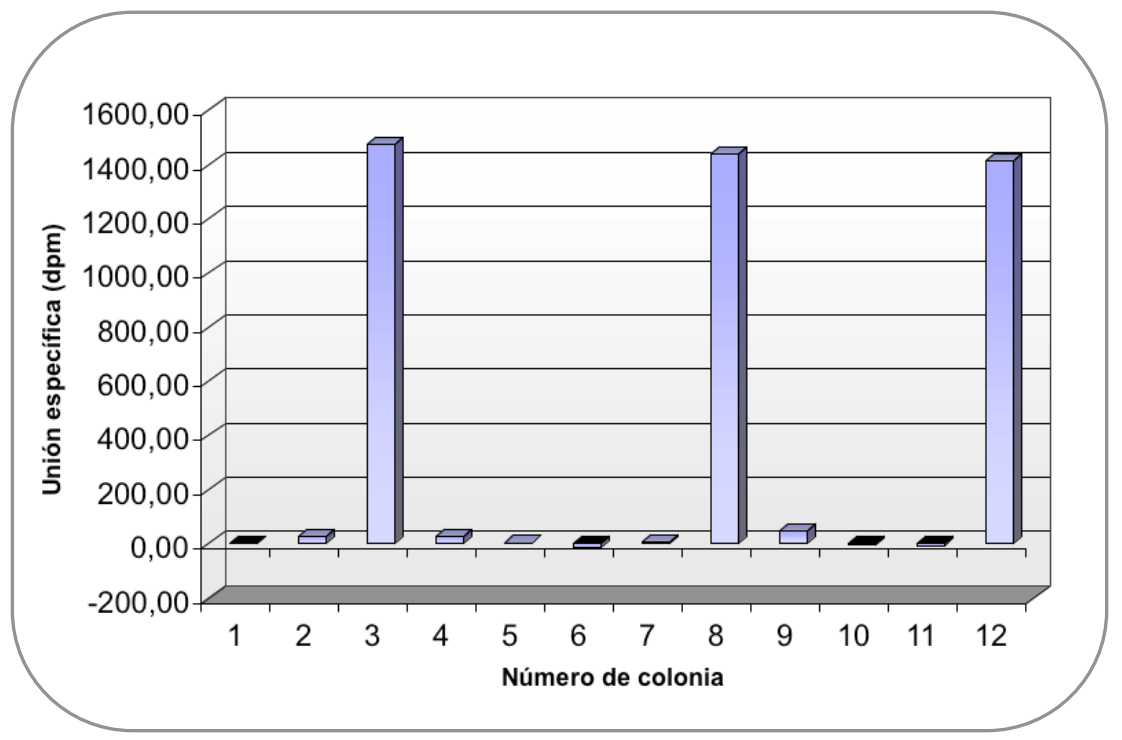

Figura 34: Tres de las colonias analizadas, la 3 , la 8 y la 12 tienen una capacidad de unión de diprenorfina marcadamente superior.

La unión específica del ligando se determina cómo la diferencia de la unión total y la unión en presencia de naloxona; los resultados indican que las colonias 3,8 y 12 presentan una unión específica en torno a las 1400 desintegraciones por minuto (dpm), mostrados en la figura 32, frente a las demás colonias cuya unión específica no sube de las 50 dpm. Tras esta comprobación la colonia 3, que es la que presenta el mayor nivel de unión, se expandió para comenzar los estudios farmacológicos. Las colonias 8 y 12 también se expandieron para poder mantener alícuotas congeladas.

\subsection{Experimentos de saturación ligando-receptor}

Los experimentos de saturación de un ligando con un receptor concreto nos permiten conocer su afinidad por el receptor, en nuestro caso zfMOR, y además la 
cantidad de ese receptor que hay en la muestra, lo que se denomina población receptorial. La limitación que presenta esta técnica es que los ligandos utilizados deben estar marcados de alguna manera o deben presentar una característica que permita la diferenciación entre el ligando unido al receptor y el ligando libre. En ocasiones, por ejemplo, se utiliza un cambio en la absorbancia del ligando o la macromolécula acontecido tras la unión, sin embargo en nuestro caso se utilizaron compuestos marcados de forma radiactiva, ya que es un sistema muy bien establecido para el estudio de receptores opioides.

El primer compuesto que utilizamos fue el antagonista opioide no selectivo diprenorfina en su forma tritiada. El estudio de saturación de este ligando nos reveló la existencia de una unión de tipo específica y saturable frente al receptor zfMOR (Figura 35). Este hecho se puede observar en la representación gráfica como una curva hiperbólica en la que un incremento en la concentración del compuesto marcado produce un incremento en la unión del mismo al receptor hasta un punto en el que el receptor queda saturado, es decir, quedan ocupados todos los sitios de unión de la muestra y por lo tanto por mucho que se aumente la cantidad del ligando marcado este no podrá unirse al receptor. Una unión no específica en este tipo de representación daría como resultado una línea recta de pendiente variable. De los datos obtenidos se pudo calcular la población receptorial $\left(\mathrm{B}_{\max }\right)$, que en el caso de la ${ }^{3} \mathrm{H}$-diprenorfina fue de $3629 \pm 169 \mathrm{fmol} / \mathrm{mg}$ de proteína y una constante de disociación $\left(\mathrm{K}_{\mathrm{d}}\right)$ de $0.52 \pm 0.1$ nM. La constante de disociación es una medida de la afinidad del ligando por el receptor siendo esta mayor cuanto menor sea el valor de la $K_{d}$. 


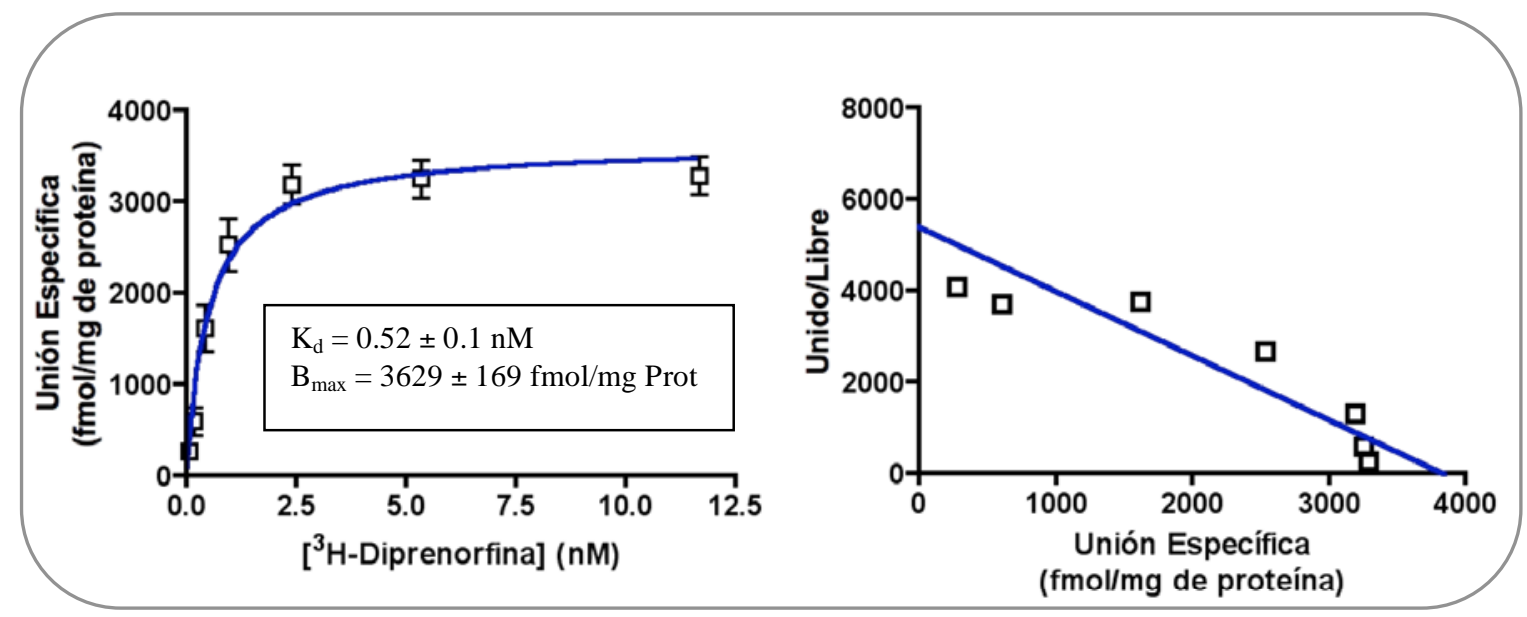

Figura 35: A: Curva de saturación utilizando ${ }^{3} \mathrm{H}$-diprenorfina en extracto purificado de membranas de células HEK-293 expresando el receptor zfMOR. B Representación de la transformación de Rosenthal. Los datos representan las medias \pm SEM de al menos tres experimentos independientes realizados por duplicado

Puesto que molecularmente nuestro receptor parece ser un receptor opioide de tipo mu, llevamos a cabo un estudio de saturación con el compuesto ${ }^{3} \mathrm{H}-\mathrm{DAMGO}$, un agonista peptídico mu selectivo (Figura 36).
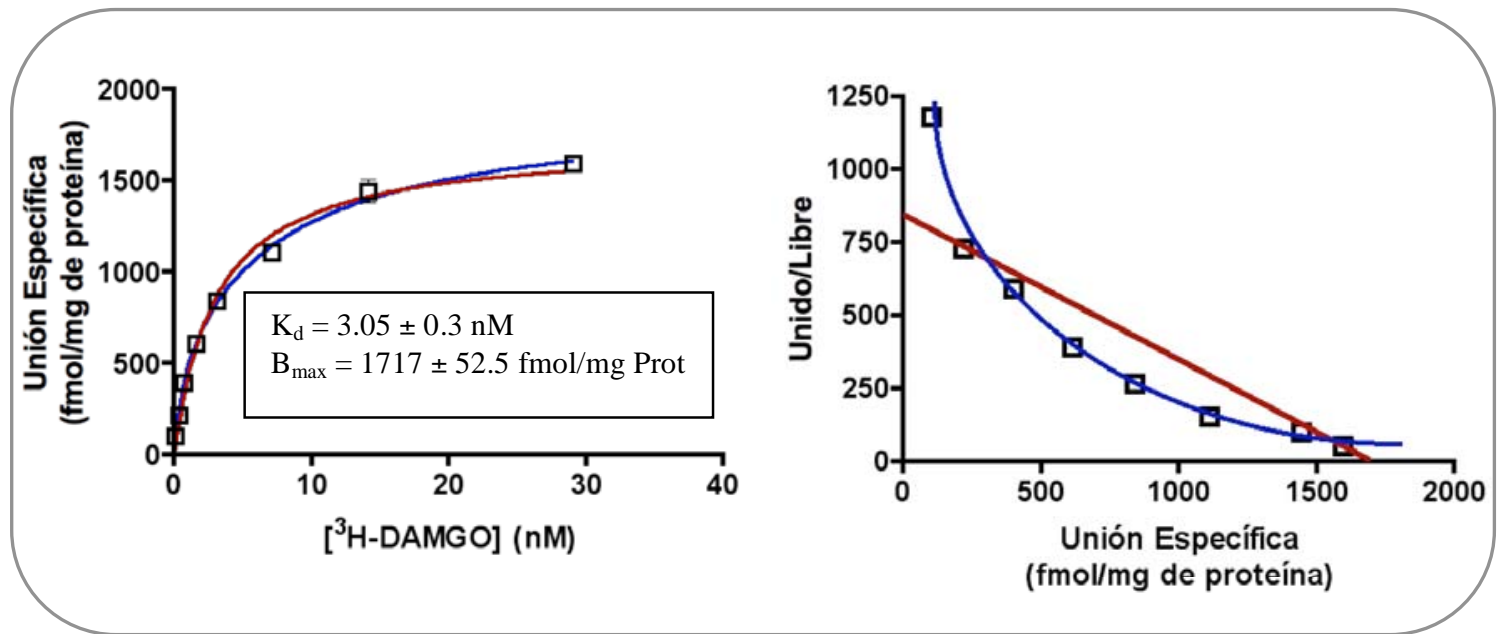

Figura 36: A: Curva de saturación utilizando ${ }^{3} \mathrm{H}-\mathrm{DAMGO}$ en extracto purificado de membranas de células HEK-293 expresando el receptor zfMOR. B Representación de la transformación de Rosenthal. En rojo se representa el ajuste a un sitio de unión y en azul a dos sitios de unión. Los datos representan las medias \pm SEM de al menos tres experimentos independientes realizados por duplicado. Sólo se señalan los valores obtenidos para el ajuste a un sitio de unión. 
Los resultados obtenidos indican sitios de unión selectivos y saturables con una población receptorial marcadamente inferior a la obtenida con la ${ }^{3} \mathrm{H}$-diprenorfina, $\mathrm{B}_{\max } 1717 \pm 52.5 \mathrm{fmol} / \mathrm{mg}$ de proteína y una $\mathrm{K}_{\mathrm{d}}$ de $3.05 \pm 0.3$ en el caso del ajuste a un sitio de unión. Para dos sitios de unión los resultados obtenidos fueron: $\mathrm{K}_{\mathrm{d}} 1=0.28$ $\pm 0.06 \mathrm{nM}, \mathrm{B}_{\max } 1=356 \pm 115 \mathrm{fmol} / \mathrm{mg}$ de proteína $\mathrm{y} \mathrm{K}_{\mathrm{d}} 2=6.13 \pm 1.42 \mathrm{nM}$ $\mathrm{B}_{\max } 2=1494 \pm 138 \mathrm{fmol} / \mathrm{mg}$ de proteína.

Para tener un control interno llevamos a cabo experimentos utilizando el receptor mu de rata cedido por el Prof. Graeme Henderson, del Departamento de Farmacología de la Universidad de Bristol. Los resultados obtenidos para este receptor utilizando ${ }^{3} \mathrm{H}$-diprenorfina se encuentran en la figura 37.

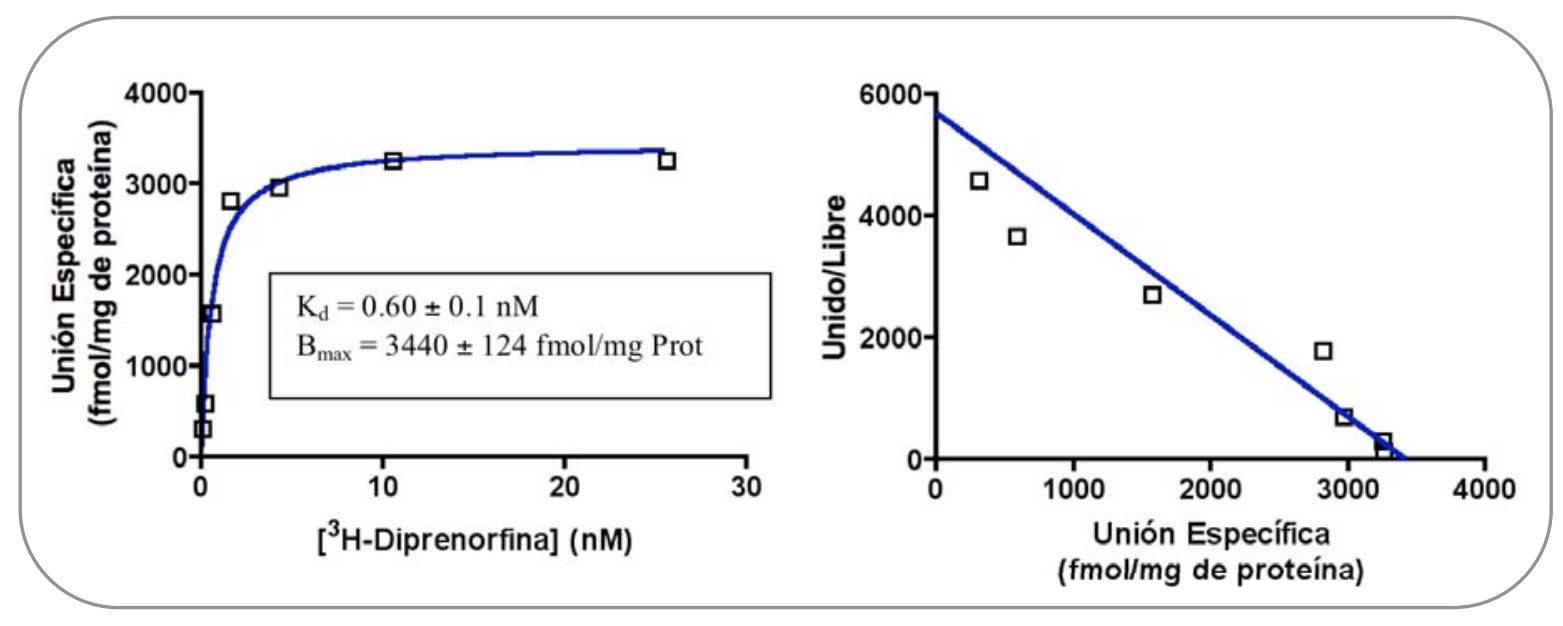

Figura 37: A: Curva de saturación utilizando ${ }^{3} \mathrm{H}$-diprenorfina en extracto purificado de membranas de células HEK-293 expresando el receptor mu de rata. B Representación de la transformación de Rosenthal. Los datos representan los resultados de un experimento característico realizado por duplicado.

Los resultados para el caso de la saturación utilizando ${ }^{3} \mathrm{H}-\mathrm{DAMGO}$ se muestran en la figura 38; se obtuvo una curva de saturación con unos valores de $\mathrm{K}_{\mathrm{d}}$ de $4.0 \pm 0.6 \mathrm{nM}$ y $B_{\max }$ de $1906 \pm 84 \mathrm{fmol} / \mathrm{mg}$ de proteína para el caso del ajuste de la curva a un sitio de unión. En el caso de dos sitios de unión los valores obtenidos 
fueron de $0.62 \pm 0.23 \mathrm{nM}$ para $\mathrm{K}_{\mathrm{d}} 1$ y $\mathrm{B}_{\max } 1$ de $615.8 \pm 138 \mathrm{fmol} / \mathrm{mg}$ de proteína; el valor de $\mathrm{K}_{\mathrm{d}} 2$ fue de $16.79 \pm 5.47 \mathrm{nM}$ y el de $\mathrm{B}_{\max } 2$ de $1803 \pm 109 \mathrm{fmol} / \mathrm{mg}$ de proteína.

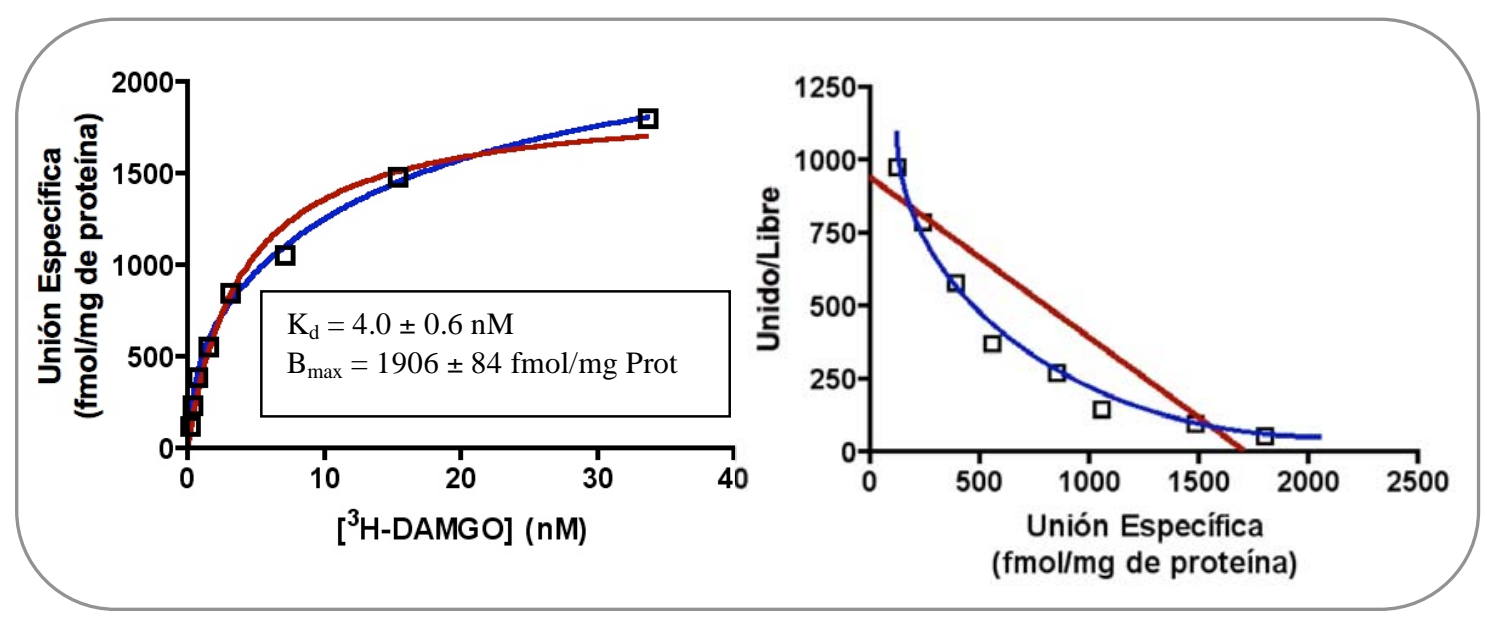

Figura 38: A: Curva de saturación utilizando ${ }^{3} \mathrm{H}-\mathrm{DAMGO}$ en extracto purificado de membranas de células HEK-293 expresando el receptor mu de rata. B Representación de la transformación de Rosenthal. En rojo se representa el ajuste a un sitio de unión y en azul a dos sitios de unión. Los datos representan los resultados de un experimento característico realizado por duplicado.

También llevamos a cabo experimentos utilizando ligandos radiactivos con selectividad delta y kappa, DPDPE y U69,593 respectivamente, para determinar una posible farmacología mixta. Ninguno de los compuestos produjo una curva de saturación indicando la no existencia de una unión específica al receptor.

Por último utilizamos el agonista no selectivo ${ }^{3} \mathrm{H}$-bremazocina y en este caso si obtuvimos una curva de saturación lo que nos indica una unión especifica, con un valor de $\mathrm{K}_{\mathrm{d}}$ de $2.1 \pm 0.27 \mathrm{nM}$. 


\subsection{Experimentos de competencia o desplazamiento}

Tras demostrar que zfMOR es capaz de unir la diprenorfina y DAMGO y que esa unión es desplazada por naloxona (unión de tipo opioide), quisimos llevar a cabo un estudio utilizando una mayor variedad de compuestos opioides. Puesto que no disponemos de dichos compuestos en su forma radiactiva no podemos llevar a cabo estudios de saturación por lo que optamos por estudios de competencia o desplazamiento. En este tipo de estudios se utiliza una concentración fija de un compuesto radiactivo del cual se conoce su valor de afinidad o $\mathrm{K}_{\mathrm{d}}$ por el receptor $\mathrm{y}$ una batería de concentraciones del compuesto a estudiar. De esta forma los ligandos compiten por su unión al receptor y se obtienen curvas denominadas curvas de desplazamiento o competencia de las que se puede extraer un valor de afinidad del ligando por el receptor denominado $\mathrm{EC}_{50} \mathrm{o}$ dosis efectiva media. Con los resultados obtenidos podremos comparar la afinidad de los distintos agentes opioides con los encontrados en receptores opioides de tipo mu de otros organismos.

Para realizar estos experimentos utilizamos una concentración de ${ }^{3} \mathrm{H}-$ diprenorfina de 4 nM, lo que corresponde a unas 50000 dpm por tubo de reacción, de acuerdo con el ligando tritiado que utilizamos. Este valor nos permite obtener una curva completa de desplazamiento por estar cercano al valor de $\mathrm{K}_{\mathrm{d}}$ del receptor por la diprenorfina tritiada y es a la vez una concentración suficientemente alta para evitar la depleción del ligando durante la reacción. La validez del modelo de ajuste de los datos a las curvas parte de la premisa de que la concentración de ligando frío no varía en el tubo de reacción mientras se alcanza el equilibrio. Esto permite tomar la concentración de ligando frío como una constante lo que simplifica 
considerablemente el modelo, lo que se consigue nadiendo una concentración de ligando tritiado alta.

Los resultados obtenidos en estos experimentos se muestran en la figura 39.

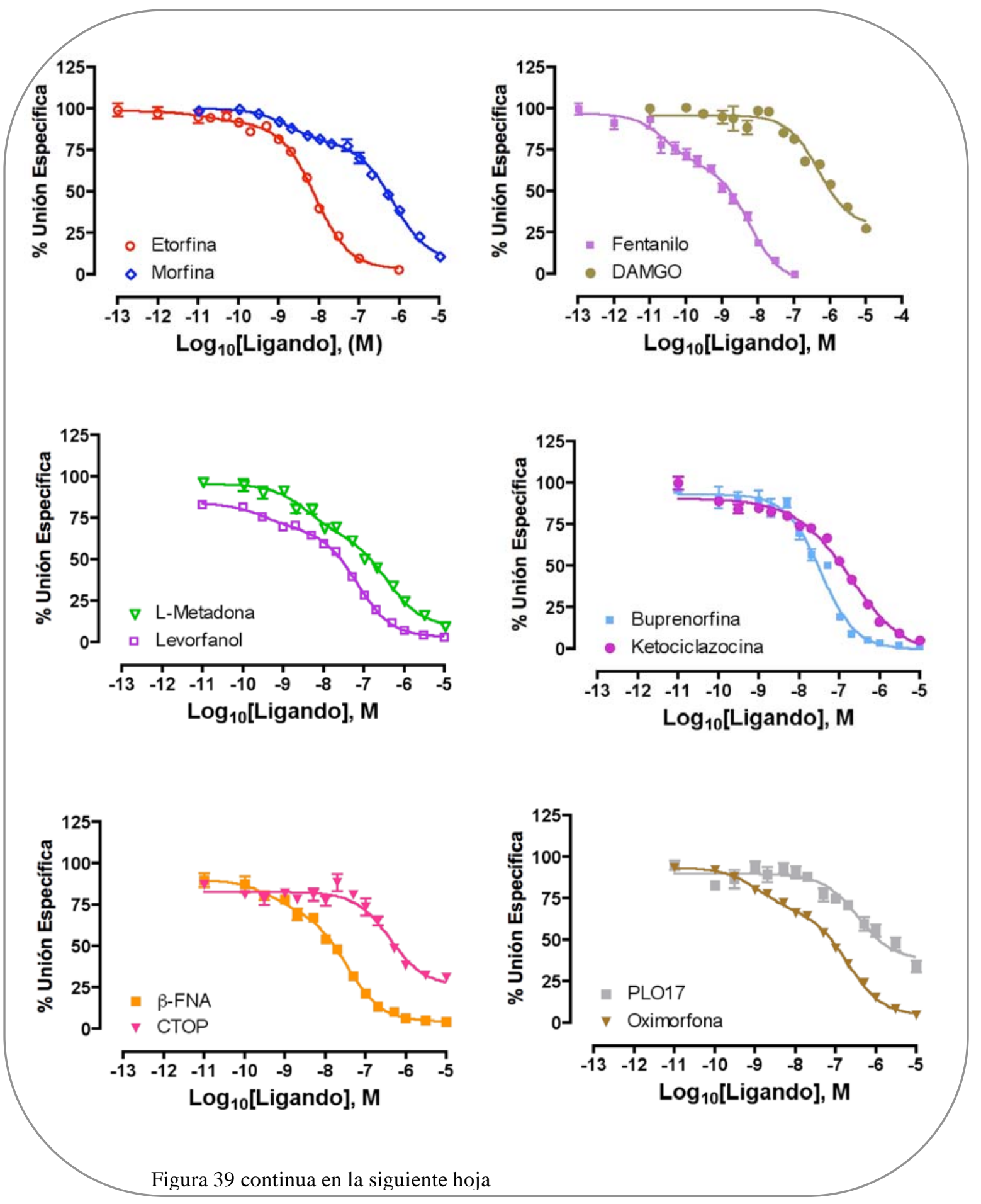



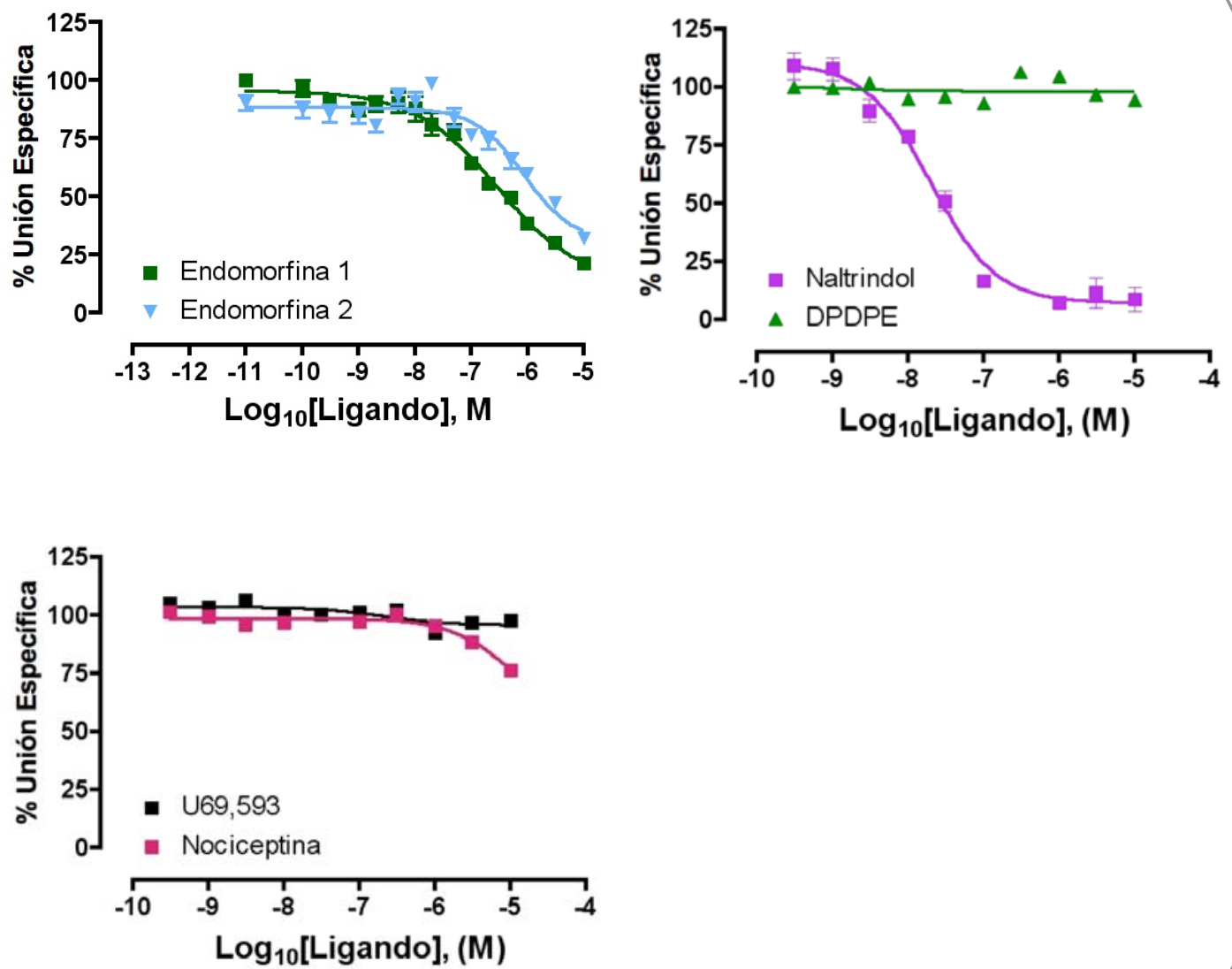

Figura 39: Curvas de desplazamiento de ${ }^{3} \mathrm{H}$-diprenorfina con distintos ligandos opioides sobre extractos membranas purificadas de células HEK-293 que expresan el receptor zfMOR. Las curvas representan las medias \pm SEM de al menos tres experimentos independientes realizados por triplicado.

Los valores de afinidad para cada uno de los compuestos utilizados así como el porcentaje de desplazamiento se encuentra resumido en la tabla 4 


\begin{tabular}{|c|c|c|c|}
\cline { 2 - 4 } \multicolumn{1}{c|}{} & \multicolumn{3}{c|}{ zfMOR } \\
\cline { 2 - 4 } \multicolumn{1}{c|}{} & Ki alta (nM) & Ki baja (nM) & $\%$ Desplazamieto \\
\hline DAMGO & $1,72 \pm 0,6$ & $229 \pm 38$ & 73,3 \\
\hline Endomorfina 1 & $0,035 \pm 0,0086$ & $64 \pm 17$ & 75,4 \\
\hline Endomorfina 2 & $251 \pm 64$ & - & 70 \\
\hline CTOP & $118 \pm 26$ & - & 73,7 \\
\hline PL017 & $104 \pm 36$ & - & 62,8 \\
\hline Morfina & $0,52 \pm 0,23$ & $202 \pm 18$ & 91,7 \\
\hline Oximorfona & $0,36 \pm 0,006$ & $57,4 \pm 5,2$ & 95,3 \\
\hline Levorfanol & $0,09 \pm 0,03$ & $19,3 \pm 1,1$ & 96,7 \\
\hline Etorfina & $0,0015 \pm 0,0007$ & $2,33 \pm 0,18$ & 96,7 \\
\hline Buprenorfina & $10,10 \pm 1,0$ & - & 100 \\
\hline BFNA & $0,17 \pm 0,06$ & $10 \pm 1,0$ & 95,4 \\
\hline L-Metadona & $11,10 \pm 0,94$ & $110 \pm 22$ & 100 \\
\hline Fentanilo & $1,25 \pm 0,4$ & $87,5 \pm 12$ & 100 \\
\hline Ketociclazocina & $19,38 \pm 0,047$ & $57,7 \pm 2,9$ & 95,5 \\
\hline Naltrindol & $11.9 \pm 1.2$ & - & 100 \\
\hline DPDPE & $>10000$ & - & - \\
\hline U69,593 & $>10000$ & - & - \\
\hline Nociceptina & $>10000$ & - & - \\
\hline
\end{tabular}

Tabla 4: Valores de $\mathrm{K}_{\mathrm{i}}$ obtenidos a partir de la ecuación de Cheng-Prusoff (Cheng y Prusoff, 1973), en la mayoría de los casos se encuentran dos sitios de unión, uno de alta afinidad y uno de baja afinidad. También se observa el porcentaje máximo de desplazamiento.

\subsection{Estudios de actividad funcional del receptor zfMOR}

Una vez caracterizada la unión de los distintos ligandos al receptor, el siguiente paso fue la comprobación de si dicha unión se traducía en una respuesta intracelular, es decir, si se activan las rutas de señalización intracelular propias de los receptores opioides. Para este propósito se utilizó una técnica basada en la unión de $\left[{ }^{35} \mathrm{~S}\right]-\mathrm{GTP} \gamma \mathrm{S}$ a las proteínas G. Mediante esta técnica podemos determinar si un compuesto determinado es capaz de producir la activación de las proteínas G heterotriméricas a las que se acoplan a los receptores opioides, lo que implica, la activación del receptor. También nos permite definir si un compuesto funciona como 
agonista, antagonista, agonista inverso o agonista parcial sobre el receptor. Un agonista es aquel compuesto que produce una activación del receptor mientras que un antagonista no produce activación alguna. El agonista parcial es aquel compuesto que produce una activación menor de aquel compuesto denominado agonista, es decir, la definición de los agonistas parciales se hace en función de los agonistas. El agonista inverso es aquel compuesto que provoca una respuesta contraria a la que produce el agonista.

Una primera aproximación en el estudio de la activación del receptor zfMOR fue la utilización de una batería de compuestos formada por agonistas y antagonistas tanto selectivos para el receptor opioide mu, como no selectivos a una concentración saturante $(10 \mu \mathrm{M})$. Este experimento permite definir cada uno de los compuestos en función de los efectos que produzca sobre las proteínas G .

Tal y como se ve en la figura 40, en el caso del receptor zfMOR, la naloxona y la diprenorfina, ambos antagonistas no selectivos no producen ningún tipo de activación de la ruta de las proteínas G. Este mismo resultado se observa en el caso del antagonista mu selectivo CTOP. También se utilizaron compuestos como DAMGO, fentanilo y morfina, todos ellos agonistas mu selectivos produciéndose una marcada activación del receptor. Esa activación también se pudo observar en el caso de las encefalinas, consideradas de forma clásica como compuestos tipo delta aunque se unen a los otros receptores opioides clásicos. 


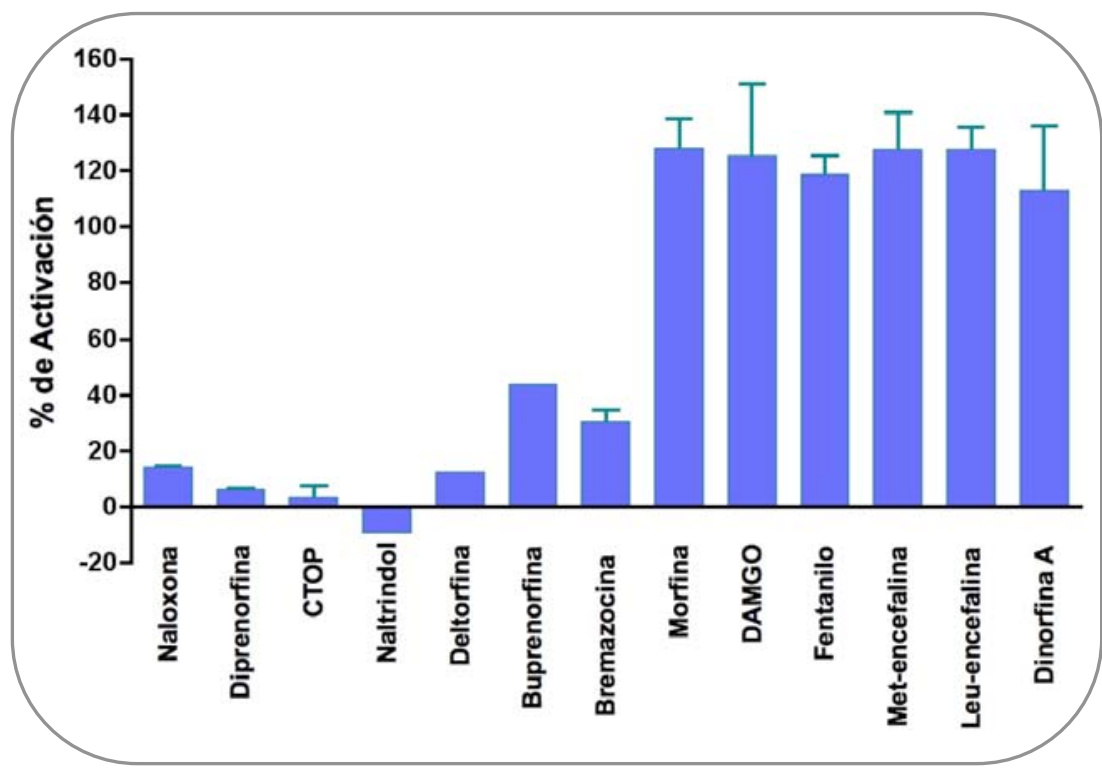

Figura 40: Ensayos de estimulación de la unión de $\left[{ }^{35} \mathrm{~S}\right]-\mathrm{GTP} \gamma \mathrm{S}$ sobre extractos de membranas purificadas de células HEK-293 que expresan el receptor zfMOR con una concentración saturante de distintos agonistas y antagonistas opioides. Los datos representan las medias de tres experimentos independientes realizados por triplicado.

Una vez determinada la capacidad de activación del receptor llevamos a cabo un estudio más profundo utilizando un número mayor de compuestos así como diferentes concentraciones de cada uno de ellos para poder obtener las curvas de activación (Figura 41).

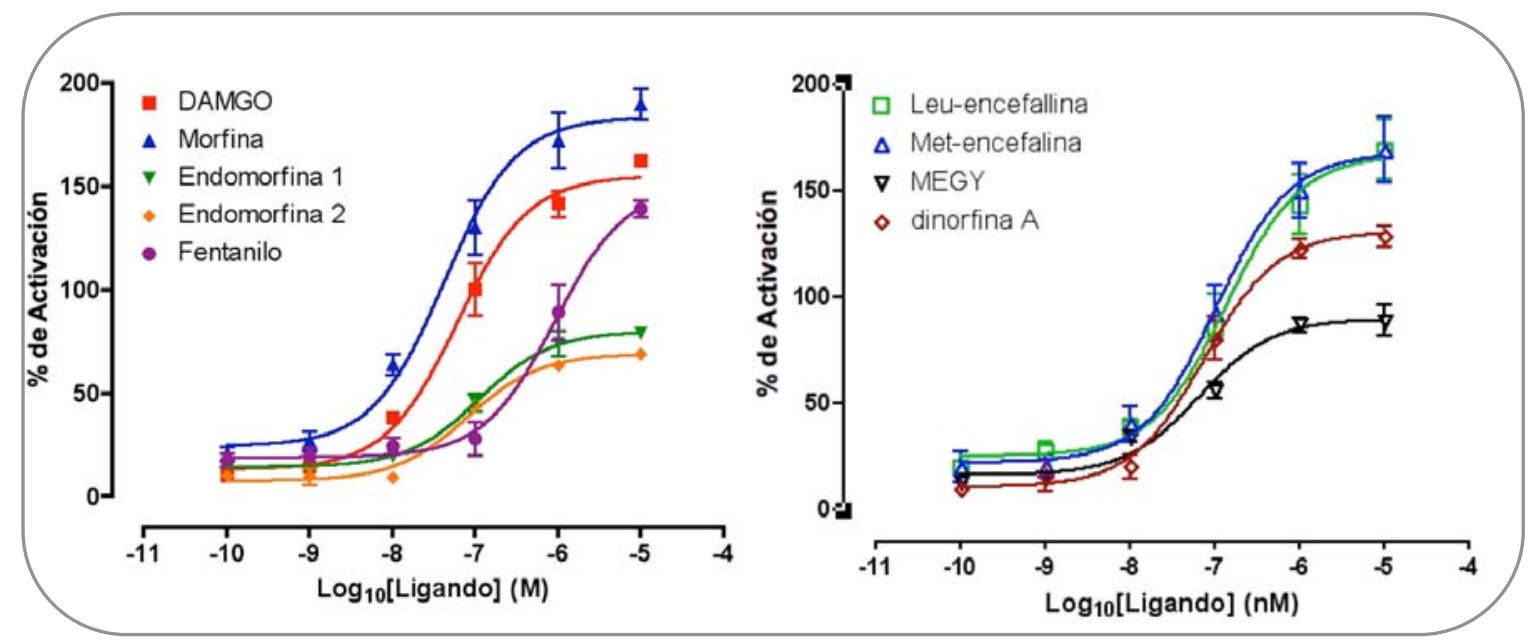

Figura 41: Curvas de activación con distintos ligandos opioides sobre extractos membranas purificadas de células HEK-293 que expresan el receptor zfMOR. Las curvas representan las medias \pm SEM de al menos tres experimentos independientes realizados por triplicado.

En la tabla 5 se pueden ver resumidos los valores obtenidos de $\mathrm{EC}_{50}$, medida de la potencia del ligando, y activación máxima, medida de la eficacia, para cada uno de los compuestos estudiados. 


\begin{tabular}{|c|c|c|c|}
\cline { 2 - 4 } \multicolumn{1}{c|}{} & DAMGO & Endomorfina 1 & Endomorfina 2 \\
\hline \hline EC50 $(\mathrm{nM})$ & $83 \pm 12$ & $112 \pm 39$ & $83 \pm 12$ \\
\hline TOP $(\%)$ & $155.4 \pm 5.6$ & $80.2 \pm 2.9$ & $69.3 \pm 2.2$ \\
\cline { 2 - 4 } \multicolumn{1}{c|}{} & Fentanilo & Morfina & MEGY \\
\hline \hline EC50 $(\mathrm{nM})$ & $1059 \pm 199$ & $46 \pm 9$ & $65 \pm 7$ \\
\hline TOP $(\%)$ & $150.9 \pm 10.9$ & $183.7 \pm 6.6$ & $89.30 \pm 3.5$ \\
\cline { 2 - 4 } \multicolumn{1}{c|}{} & Dinorfina A & Leu-encefalina & Met-encefalina \\
\hline \hline EC50 $(\mathrm{nM})$ & $99 \pm 6$ & $156 \pm 37$ & $106 \pm 7$ \\
\hline TOP $(\%)$ & $130.4 \pm 6.1$ & $166.4 \pm 8.9$ & $167.3 \pm 8.4$ \\
\hline
\end{tabular}

Tabla 5: Valores calculados de $\mathrm{EC}_{50}$ y Activación máxima del receptor (TOP) para los compuestos utilizados. Los valores representan las medias \pm SEM de al menos tres experimentos independientes realizados por triplicado.

\subsection{Estudio del acoplamiento a la ruta de la adenilato ciclasa}

El estudio del acoplamiento a la ruta de la adenilato ciclasa es otro método utilizado para obtener información acerca de la funcionalidad del receptor, en este caso no de forma directa como en el caso de la activación de proteínas $\mathrm{G}$, sino a través de un proceso de amplificación de la señal. En este tipo de experimentos lo que medimos es una reducción en la concentración de AMPc intracelular como consecuencia de la inhibición de la adenilato ciclasa producida por la activación de los receptores opioides. El hecho de que la concentración del AMPc intracelular en condiciones normales sea muy pequeña hace necesaria la utilización de un compuesto, la forscolina que va a producir un aumento considerable en la concentración de AMPc intracelular de forma que las diferencias una vez el receptor este activado sean mayores y puedan ser detectadas con mayor precisión.

El primer compuesto que utilizamos en este tipo de experimentos fue la etorfina, un agonista opioide no selectivo con una potencia analgésica 10000 superior 
a la de la morfina. Como podemos ver en la primera gráfica de la figura 42 la etorfina es marcadamente mas potente que otros compuestos como la morfina, el fentanilo, la metadona o DAMGO, siendo incluso necesario utilizar concentraciones hasta 2 rangos inferiores para poder obtener una grafica completa. Los valores de EC50 e inhibición máxima se pueden observar en la tabla 6. También llevamos a cabo un experimento utilizando la toxina pertúsica; esta toxina afecta directamente a las subunidades $\alpha$ de algunas proteínas $G$, específicamente a las $G_{i / 0}$, produciendo su ribosilación y por tanto inactivación. Como se puede ver en la figura 42 cuando se hace un tratamiento previo con toxina pertúsica la capacidad de inhibición de la adenilato ciclasa se ve prácticamente abolida incluso a concentraciones muy altas. También quisimos determinar la especificidad de el efecto observado con la etorfina y para ello estudiamos la capacidad de distintos antagonistas de bloquear la acción de la etorfina. En la figura 42 se pueden ver los resultados cuando se utilizaron la diprenorfina, naloxona y $\beta$ FNA; todos ellos en mayor o menor medida son capaces de bloquear la señalización del receptor y como se ve en la figura 43 hemos utilizado una serie de compuestos opioides para poder establecer posibles diferencias con los receptores opioides de mamífero.

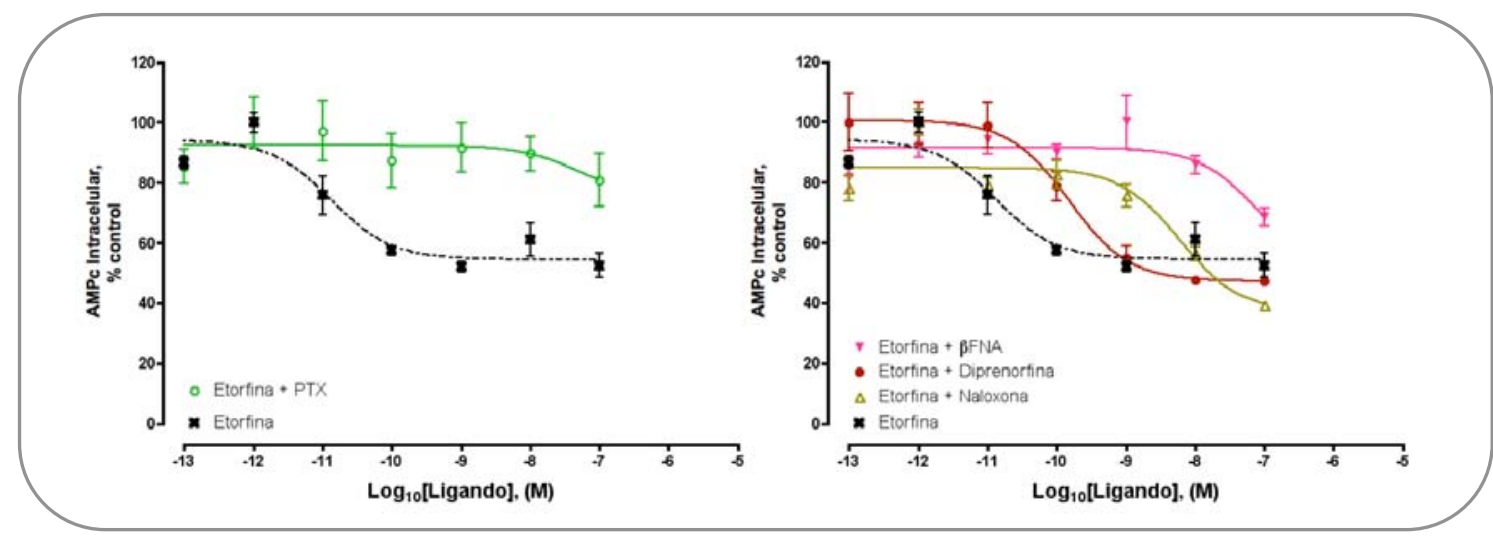

Figura 42. Curvas dosis-respuesta de la inhibición de la actividad de la adenilato ciclasa utilizando etorfina en células HEK-293 transfectadas de forma estable con el receptor zfMOR. Se ha utilizado también un pretratamiento con toxina pertúsica (PTX) para determinar el tipo de proteína G implicada en la señalización. También se han utilizado diversos antagonistas para determinar la capacidad de bloqueo del efecto de la etorfina. Las curvas representan las medias \pm SEM de al menos tres experimentos independientes realizados por triplicado. 


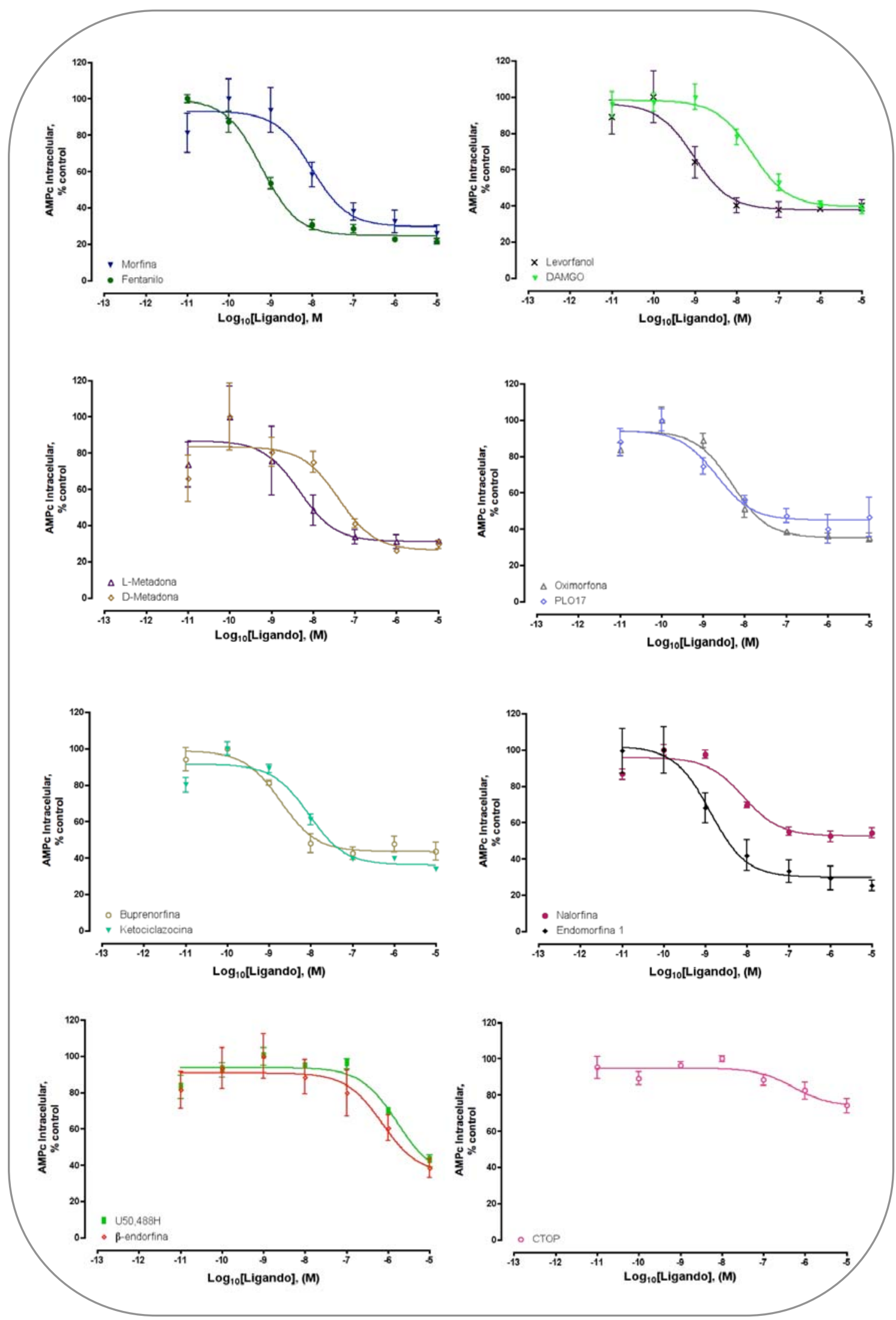

Figura 43. Curvas dosis-respuesta de la inhibición de la actividad de la adenilato ciclasa utilizando distintos ligandos en células HEK-293 transfectadas de forma estable con el receptor zfMOR. Las curvas representan las medias \pm SEM de al menos tres experimentos independientes realizados por triplicado. 


\begin{tabular}{|c|c|c|}
\cline { 2 - 3 } \multicolumn{1}{c|}{} & \multicolumn{2}{c|}{ zfMOR } \\
\cline { 2 - 3 } \multicolumn{1}{c|}{} & $\mathrm{EC50}(\mathrm{nM})$ & Max inh $\%$ \\
\hline 及-endorfina & $593,3 \pm 260$ & $55,41 \pm 8,95$ \\
\hline DAMGO & $23,41 \pm 4,9$ & $58,74 \pm 2,14$ \\
\hline Endomorfina 1 & $1,31 \pm 0,45$ & $72,33 \pm 1,47$ \\
\hline Endomorfina 2 & $1,95 \pm 0,19$ & $42,12 \pm 4,27$ \\
\hline CTOP & $528,7 \pm *$ & - \\
\hline PLO17 & $2,11 \pm 3,2$ & $49,41 \pm 5,88$ \\
\hline Morfina & $10,05 \pm 1,4$ & $63,57 \pm 4,85$ \\
\hline Oximorfona & $5,02 \pm 1,2$ & $58,75 \pm 2,83$ \\
\hline Nalorfina & $8,25 \pm 0,89$ & $43,39 \pm 3,66$ \\
\hline Levorfanol & $0,94 \pm 0,22$ & $58,93 \pm 2,90$ \\
\hline Etorfina & $0,013 \pm 0,0028$ & $39,61 \pm 0,48$ \\
\hline Buprenorfina & $1,89 \pm 0,43$ & $55,48 \pm 2,86$ \\
\hline L-Metadona & $4,71 \pm 1,6$ & $55,65 \pm 4,15$ \\
\hline Fentanilo & $0,61 \pm 0,17$ & $75,22 \pm 0,35$ \\
\hline Ketociclazocina & $9,05 \pm 3,5$ & $55,46 \pm 0,02$ \\
\hline U50,488H & $1623,8 \pm 380$ & $60,06 \pm 4,01$ \\
\hline
\end{tabular}

Tabla 6: Valores de $\mathrm{EC}_{50}$, una medida de la potencia de un compuesto a la hora de inhibir la producción de AMPc; a menor valor de $\mathrm{EC}_{50}$ mayor potencia. Los valores de inhibición máxima que hacen referencia a la eficacia del compuesto, a mayor valor de inhibición máxima de la adenilato ciclasa mayor será la eficacia. En la tabla se muestran los resultados de al menos tres experimentos realizados por triplicado y de forma independiente. El asterisco indica un error estándar de la media elevado.

También llevamos a cabo algunos experimentos para estudiar el acoplamiento a la ruta de la adenilato ciclasa utilizando células HEK-293 que expresaban el receptor opioide mu de rata (denominadas HEK MT; obsequio del profesor Ping-Yee Law del Departamento de Farmacología de la Universidad de Minnesota). Los resultados obtenidos se muestran en la tabla 7 en la cual también aparecen resultados de desplazamiento utilizando ${ }^{3} \mathrm{H}$-diprenorfina y distintos ligandos opioides.

\begin{tabular}{|c|c|c|c|c|}
\hline \multirow[b]{3}{*}{ Compuesto } & \multicolumn{4}{|c|}{ HEK MT } \\
\hline & \multicolumn{2}{|c|}{ CAMP } & \multicolumn{2}{|c|}{ Competition } \\
\hline & EC50 (nM) & Max. Inh. \% & Ki alta (nM) & Ki baja (nM) \\
\hline DAMGO & $2 \pm 0.7$ & $88.6 \pm 4.3$ & $0.34 \pm 0.12$ & $98 \pm 12$ \\
\hline Endomorfina 1 & $4.88 \pm 1.0$ & $73.62 \pm 1.1$ & $3.0 \pm 0.8$ & $250 \pm 55$ \\
\hline Endomorfina 2 & $5.63 \pm 0.5$ & $70.86 \pm 3.3$ & $3.4 \pm 1.5$ & $210 \pm 65$ \\
\hline CTOP & \multicolumn{2}{|c|}{-} & \multicolumn{2}{|c|}{$9.7 \pm 1.4$} \\
\hline PL017 & $6.54 \pm 0.89$ & $60.61 \pm 1.8$ & \multicolumn{2}{|c|}{$150 \pm 28$} \\
\hline Morfina & $9.8 \pm 3.3$ & $87.1 \pm 4.5$ & $0.28 \pm 0.09$ & $37 \pm 8$ \\
\hline Oximorfona & $6.13 \pm 0.9$ & $64.76 \pm 3.8$ & \multicolumn{2}{|c|}{-} \\
\hline Nalorfina & $13.3 \pm 5.4$ & $36.95 \pm 4.9$ & \multicolumn{2}{|c|}{-} \\
\hline Levorfanol & 0.590 .24 & $59.61 \pm 2.3$ & \multicolumn{2}{|c|}{-} \\
\hline Etorfina & $0.077 \pm 0.04$ & $87.5 \pm 2.0$ & \multicolumn{2}{|c|}{$1.6 \pm 0.5$} \\
\hline Buprenorfina & $24.4 \pm 13$ & $65.63 \pm 7.9$ & \multicolumn{2}{|c|}{-} \\
\hline L-Metadona & $6.91 \pm 2.8$ & $52.77 \pm 1.3$ & \multicolumn{2}{|c|}{-} \\
\hline Fentanilo & $1.21 \pm 0.26$ & $69.27 \pm 3.2$ & \multicolumn{2}{|c|}{-} \\
\hline Ketociclazocina & $2.1 \pm 1.1$ & $47.47 \pm 4.9$ & \multicolumn{2}{|c|}{-} \\
\hline
\end{tabular}

Tabla 7: Resultados obtenidos en los experimentos de AMPc y desplazamientos utilizando el receptor mu de rata expresado en células HEK-293 (HEK MT). Los valores representan las medias \pm SEM de al menos tres experimentos independientes realizados por triplicado. 


\subsection{Obtención de las construcciones marcadas (Tagged)}

El primer paso para la obtención de los receptores con los epítopos FLAG y HA fue el diseño de los oligonucleótidos. Los oligonucleótidos sentido o forward se diseñaron para que parte de los mismos anillaran en la zona 5' no traducida (5' UTR o Untranslated region) de zfMOR, a continuación se encontraría el ATG iniciador de zfMOR, luego la secuencia correspondiente al epítopo HA o FLAG, que formará un bucle una vez se produzca el anillamiento con la secuencia diana, y por último de $10 \mathrm{a}$ 12 nucleótidos correspondientes a la zona 3' a partir del ATG iniciador de zfMOR. El otro oligonucleótido, el antisentido o reward anillaría en una región interna de zfMOR. Para determinar esa zona se buscaron dos objetivos. En primer lugar, que el producto de PCR sintetizado tuviese una longitud tal que para ser secuenciado posteriormente no se necesitara un oligonucleótido interno. Además, se buscó una zona donde existiese un sitio de corte único para una enzima de restricción y que a su vez, ese sitio de corte, no apareciera en la secuencia del plásmido, es decir, en la construcción solo habría un sitio de corte para la enzima seleccionada. La región seleccionada para diseñar dicho oligonucleótido comienza en el nucleótido 886 contando a partir del ATG iniciador y está compuesto por 21 nucleótidos. Además en su extremo 5' presenta un sitio de corte para la enzima BstEII. La presencia de este sitio de corte único facilita el proceso de subclonación realizado posteriormente. Las secuencias de estos oligonucleótidos se pueden observar en la figura 44, en la cual se destacan con distintos colores las distintas secuencias que conforman los oligonucleótidos diferenciadas por colores, tal como se explicaron anteriormente. También se puede observar la posición de anillamiento con el plásmido, así como el 
bucle que formaría la secuencia correspondiente los epítopos HA y FLAG una vez producido el anillamiento.

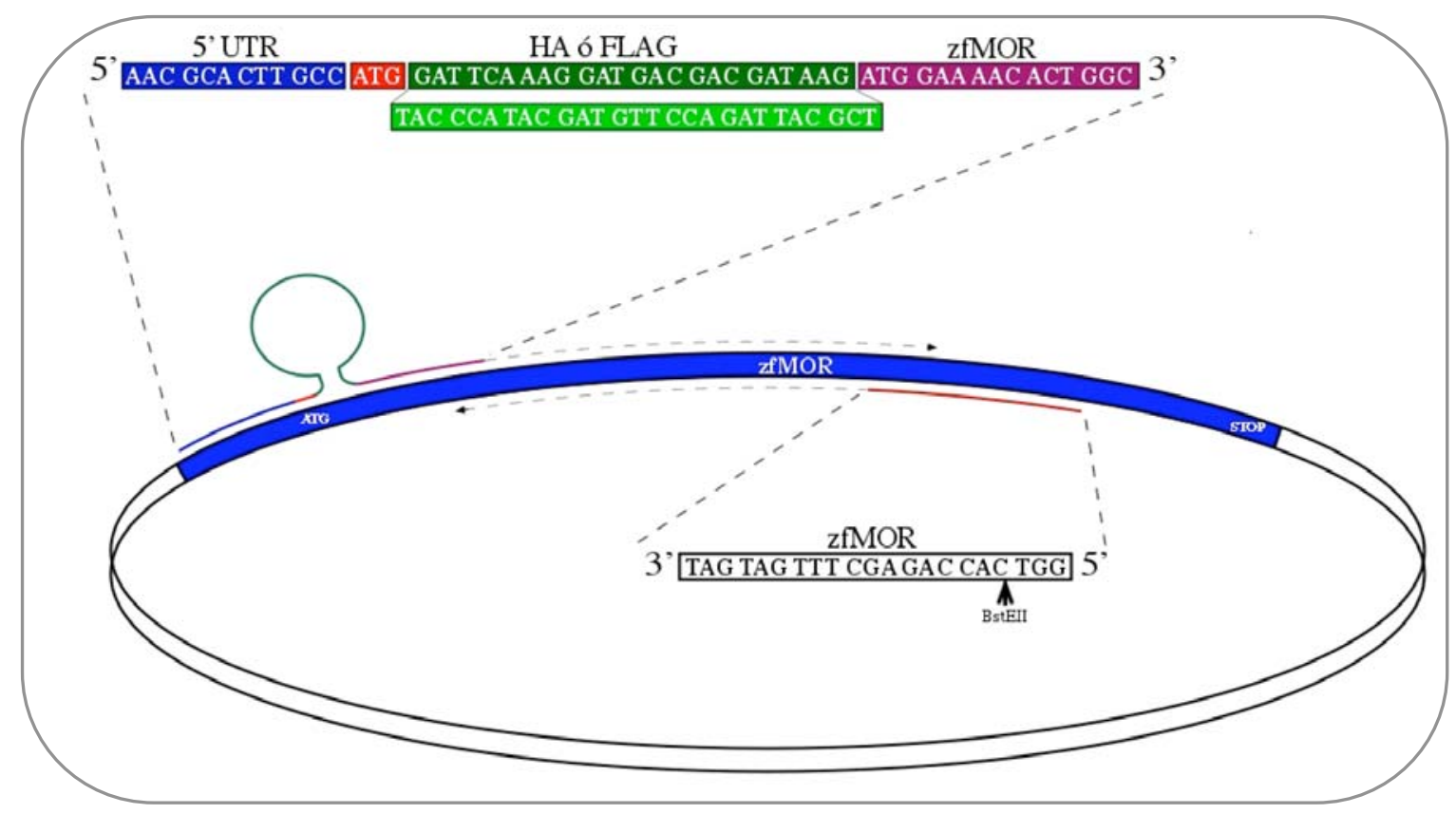

Figura 44: Esquema representativo del plásmido pcDNA3.1 con la secuencia de zfMOR insertada y los oligonucleótidos diseñados para obtener las construcciones con los epítopos HA y FLAG. En la parte superior de la figura se representa la secuencia de los oligonucleótidos sentido utilizados. En azul oscuro se localiza la secuencia presente hacia 5' del ATG iniciador de zfMOR; a continuación, en rojo, el ATG iniciador. Seguido podemos ver la secuencia de los epítopos antigénicos HA y FLAG en verde y por último, en morado, La secuencia hacia 3' del ATG iniciador. También esta representado el oligonucleótido antisentido que anilla en la parte interna de la secuencia de zfMOR y se indica el sitio de corte de la enzima de restricción BstEII.

Tras la reacción de PCR los productos obtenidos se separaron mediante electroforesis en un gel de agarosa al $0.8 \%$ (Figura 45) y las bandas del tamaño deseado se purificaron con el kit Gene clean II.

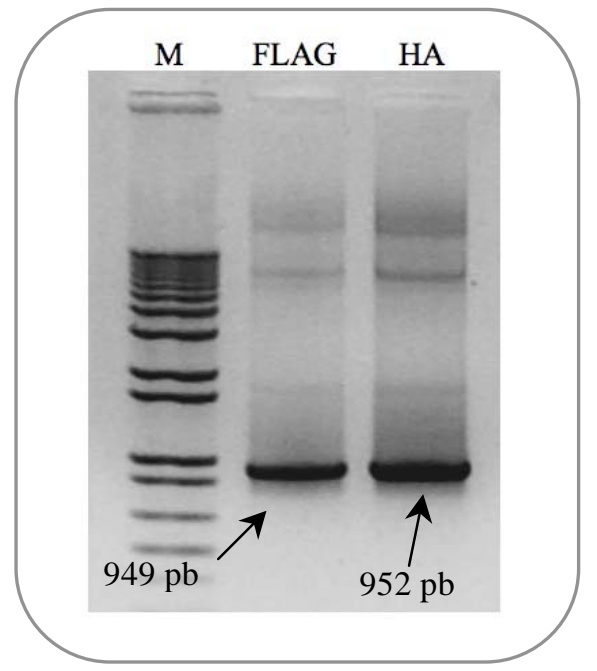

Figura 45: En la fotografía del gel se pueden observar los productos de PCR amplificados que se sitúan a la altura del tamaño esperado (949 pb para el caso de FLAG y 952 para HA).

M: Marcador de peso molecular; FLAG: Producto de PCR obtenido utilizando el oligonucleótido que introducirá la secuencia FLAG. HA: Producto de PCR obtenido utilizando el oligonucleótido que introducirá la secuencia HA. 
La clonación de los productos de PCR se llevó a cabo en el vector de clonación pCR $^{\circledR}$ II-TOPO ${ }^{\circledR}$. Tras realizar la reacción de ligación entre los productos de PCR y el plásmido se transformaron bacterias súper competentes y se sembraron en placas LB suplementadas con el antibiótico kanamicina. Varias colonias procedentes de las transformaciones con las construcciones de cada uno de los epítopos fueron seleccionadas para crecer en medio líquido y poder así analizar si contienen el plásmido con el inserto deseado.

Tras la extracción y purificación de los plásmidos se llevó a cabo un estudio por digestión con enzimas de restricción (EcoRI y BstEII) para comprobar la presencia de inserto y el tamaño del mismo. Tras las digestiones los productos se separaron mediante electroforesis en un gel de agarosa al $0.8 \%$ (Figura 46) observando que la mayoría de las colonias contenían el inserto y que éste era del tamaño correcto.

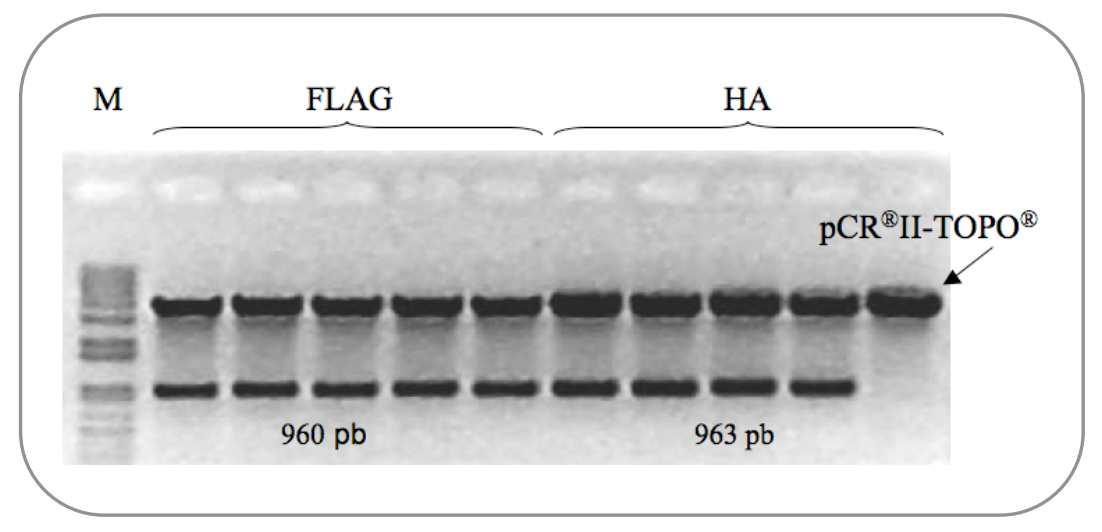

Figura 46: En la fotografía del gel se puede observar el marcador de peso molecular, en el carril de la izquierda y a continuación la digestión de 10 plásmidos, 5 con la construcción FLAG y otros 5 con la construcción HA. Se pueden ver dos bandas, una superior, correspondiente al plásmido y la otra a la altura deseada, correspondiente a parte de zfMOR con el epítopo correspondiente. En la última columna se puede ver el resultado de la ausencia de inserto. También se puede ver el tamaño de ambos insertos, 960 pb para FLAG y 963 pb para HA. Hay que tener en cuenta que son 11 pared de bases más largos que los productos de PCR ya que hay que tener en cuenta la distancia que separa el sitio de corte de EcoRI de la zona de inserción del producto de PCR. 
Se seleccionaron algunas de las colonias para secuenciar y comprobar que se había introducido correctamente la secuencia de los epítopos. Tras comprobar que las secuencias eran correctas se procedió a la subclonación en el vector se expresión eucariota pcDNA3.1. Para realizar esto tuvimos que optar por una triple ligación debido a problemas con las digestiones de uno de los plásmidos.

Para llevar a cabo esta triple ligación utilizamos, por un lado, la región 5’ del receptor zfMOR que se encontraba en el plásmido $\mathrm{pCR}^{\circledR} \mathrm{II}-\mathrm{TOPO}{ }^{\circledR}$. Por otro lado, la región 3' del receptor se obtuvo de la construcción original de zfMOR insertada en pcDNA3.1 y por último se utilizó plásmido pcDNA3.1 circular sin ningún tipo de inserto (Figura 47).

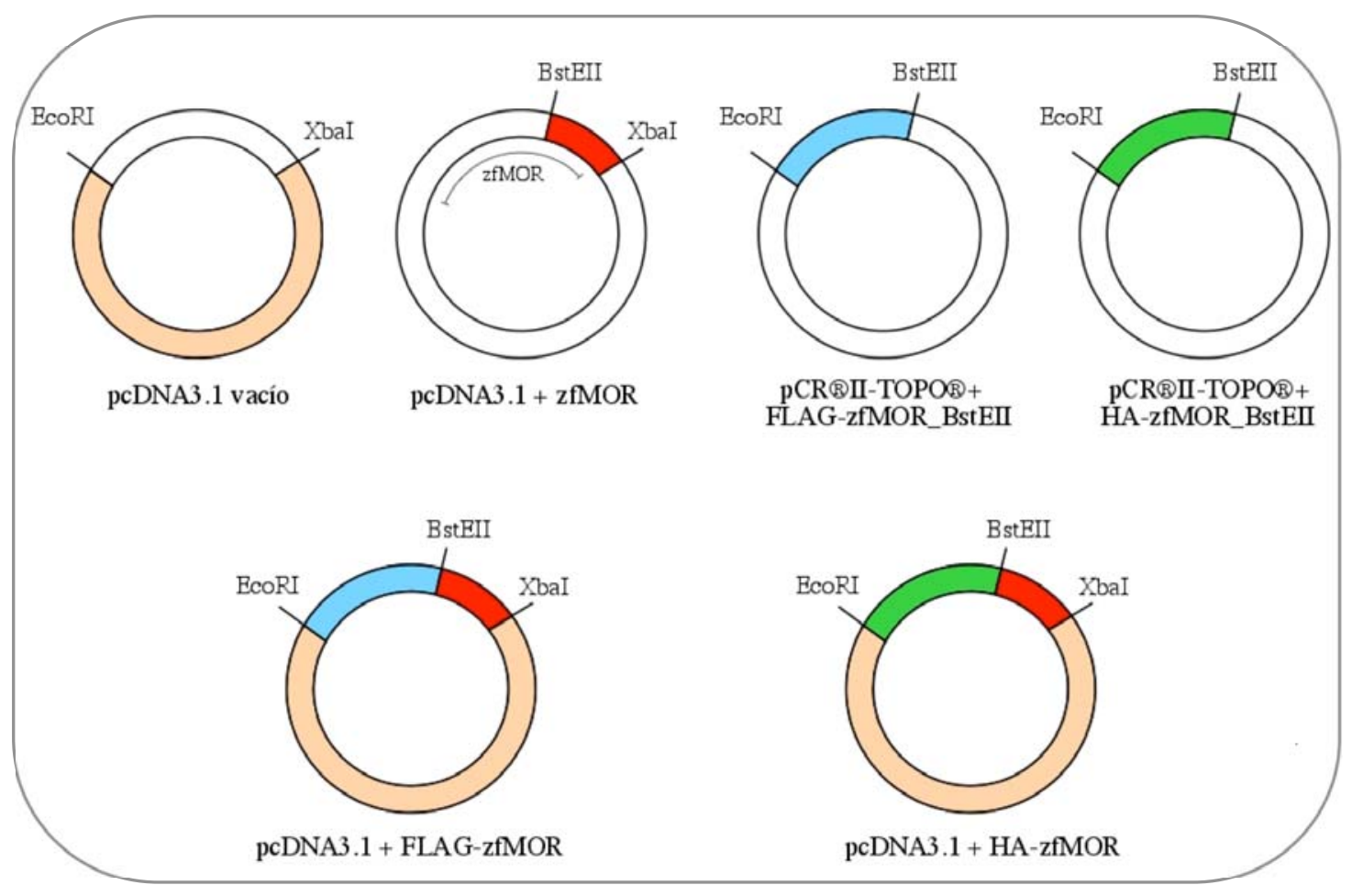

Figura 47: Esquema de cómo se realizaron las construcciones con los epítopos HA y/o FLAG. Se pueden ver los plásmidos de partida utilizados, así como los sitios de corte para las enzimas de restricción utilizadas. Para la obtención de las construcciones se optó por una triple ligación utilizando el vector pcDNA3.1 vacío, la construcción original de zfMOR en pcDNA3.1 y los fragmentos con las secuencias de HA y FLAG clonadas en el vector pCR $^{\circledR}$ II-TOPO. 
De esta manera se cortó el plásmido pCR ${ }^{\circledR} \mathrm{II}-\mathrm{TOPO}^{\circledR}$ con las enzimas EcoRI y BstEII (en este caso podemos cortar con EcoRI ya que la parte que nos interesa del inserto esta "aguas arriba" del sitio de corte en zfMOR). El plásmido pcDNA3.1 con zfMOR se cortó con las enzimas de restricción BstEII y XbaI y por último el plásmido pcDNA3.1 sin insertó se cortó con las enzimas EcoRI y XbaI.

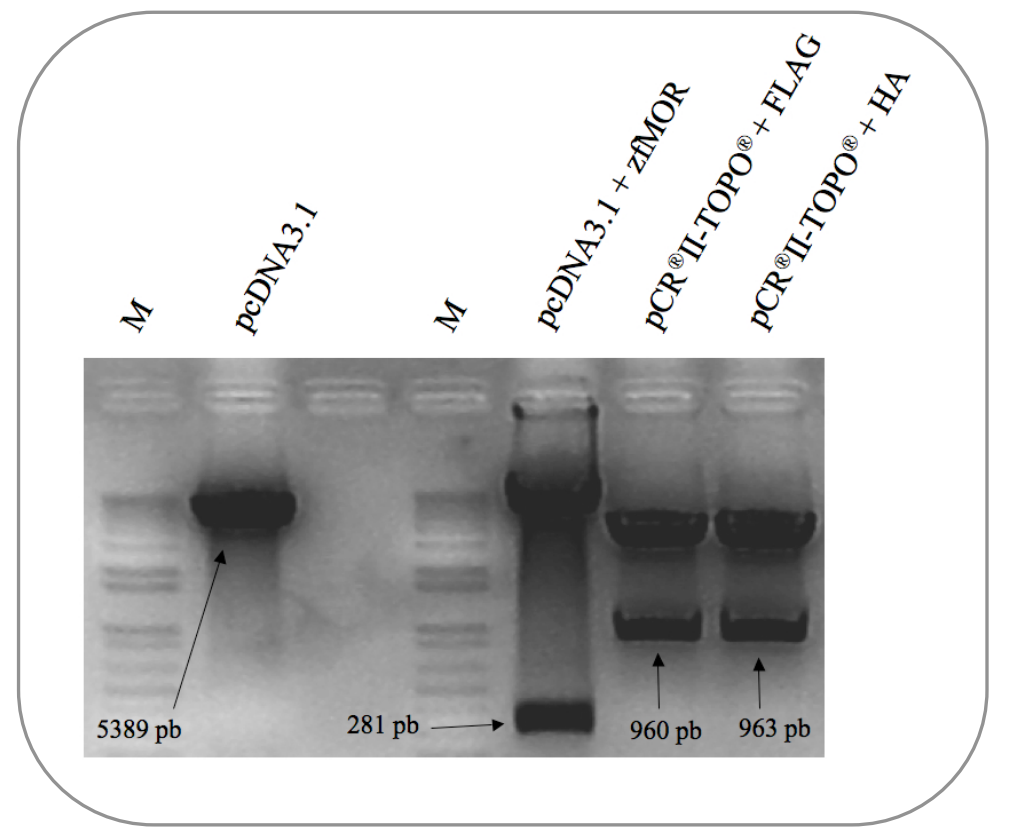

Figura 48: Digestiones que se llevaron a cabo para poder obtener la construcción con el epítopo. En el segundo carril se encuentra la digestión del plásmido pcDNA3.1 con las enzimas EcoRI y XbaI. En el quinto carril vemos la digestión de la construcción pcDNA3.1 + zfMOR con las enzimas BstEII y XbaI. En los carriles sexto y séptimo tenemos las construcciones de $\mathrm{pCR}^{\circledR} \mathrm{II}-$ TOPO $^{\circledR}$ con FLAG y HA cortados con las enzimas EcoRI y BstEII.

Tras someter los productos de digestión a una electroforesis en gel de agarosa (Figura 48) y purificar, cuantificar y en el caso del plásmido desfosfatar el DNA, se procedió a hacer una ligación triple. Tras la ligación se transformaron bacterias supercompetentes y se sembraron en placas LB con ampicilina, incubándolas toda la noche a $37^{\circ} \mathrm{C}$. Se incluyó también un control de la ligación para poder determinar la presencia de autoligación del plásmido (Figura 49). En este tipo de control, muy útil cuando se realiza un gran volumen de ligaciones-transformaciones. Junto con la ligación que se quiere realizar se utiliza una ligación en la que solo se pone el plásmido desfosfatado. Si tras sembrar en placa de agarosa aparecieran tantas colonias en el control como en la ligación problema querría decir que la capacidad de 
autoligación del plásmido es muy alta y por tanto un gran número de las colonias en la ligación problema no tendrían el plásmido con la construcción. En una buena ligación la placa control tendría 1 ó 2 colonias mientras que la placa problema puede llegar a tener entre 30 y 60 colonias.

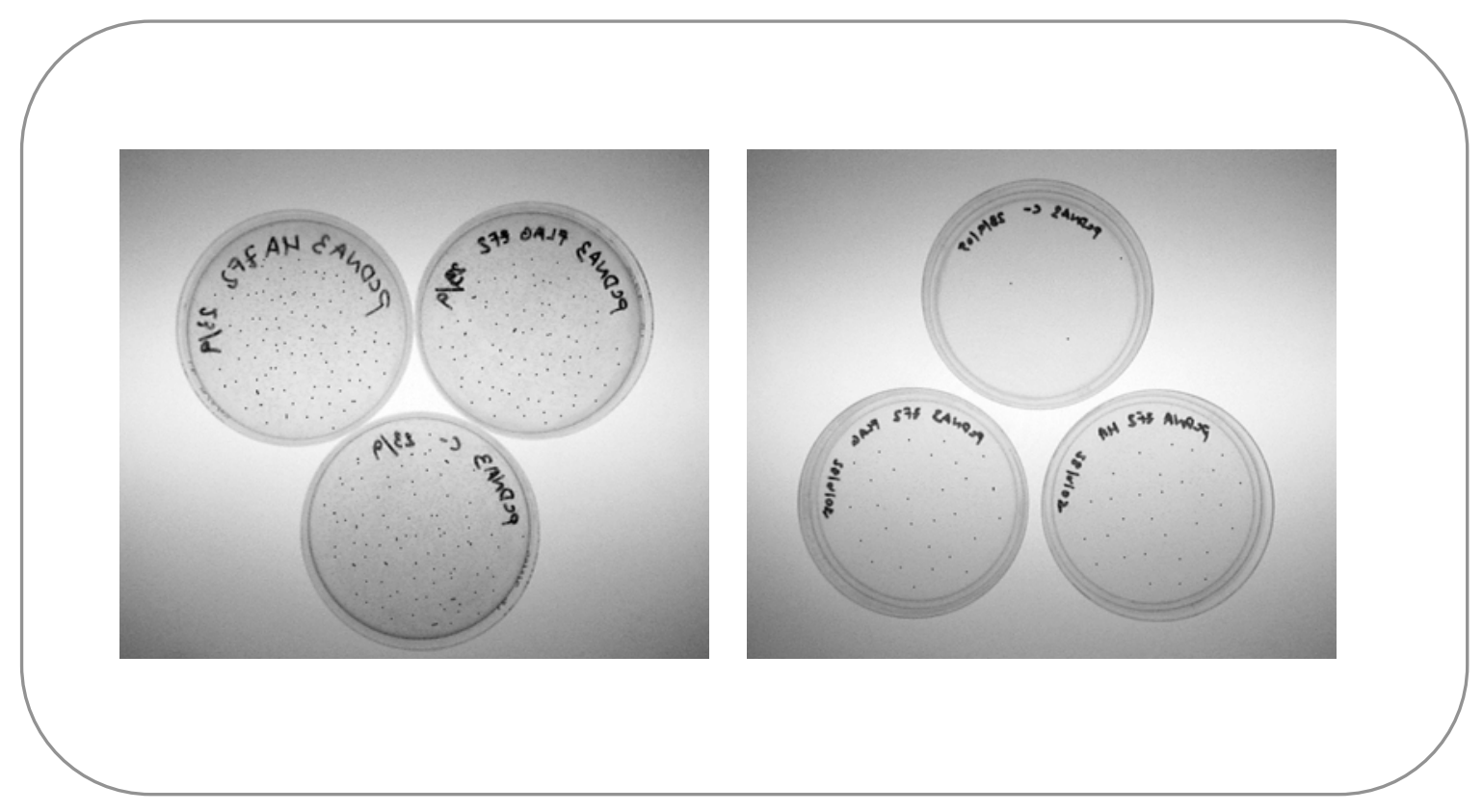

Figura 49: Fotografías a través de un transiluminador de luz visible de las placas de transformación. En las placas situadas a la izquierda se puede apreciar un patrón punteado presente tanto en la placa control (abajo) como en las placas problema. En las placas de la derecha sólo se ve un patrón punteado leve en las placas problema mientras que en la placa control no hay crecimiento bacteriano. Estas últimas placas se corresponden con una buena transformación, en la que no hay autoligación del plásmido o esta es mínima. Puesto que las colonias son transparentes y difíciles de apreciar en la fotografía se han remarcado en negro.

A continuación se seleccionaron varias de las colonias transformantes y se crecieron en medio líquido para poder purificar los plásmidos. Tras la purificación se hizo una digestión utilizando las enzimas EcoRI y XbaI (Figura 50). Tras comprobar el tamaño de los insertos se llevaron a secuenciar varias colonias de cada construcción. 


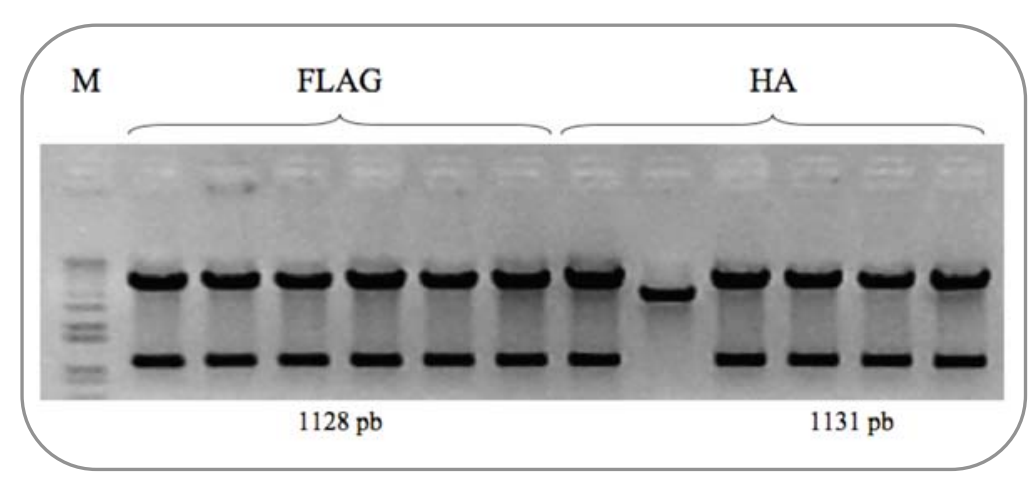

Figura 50: Digestiones de 6 plásmidos pcDNA3.1 con el inserto zfMOR-FLAG y 6 con zfMOR-HA. La digestión con las enzimas EcoRI y XbaI nos origina el tamaño de bandas adecuado, 1128 pb para FLAG y $1131 \mathrm{pb}$ para HA. En el caso de la colonia numero dos de la construcción con zfMOR-HA obtenemos un fragmento lineal que no coincide con ninguno de los tamaños esperados.

\subsection{Obtención de la construcción mutante}

Para la obtención del receptor mutado se utilizó la técnica de PCR basado en el trabajo de Fisher y Pei (1997) para introducir cambios en plásmidos sin necesidad de subclonar. En nuestro caso, los oligonucleótidos generados anillan de forma específica en los flancos de la secuencia que queremos delecionar formándose un bucle de nueve restos de nucleótido en el DNA molde. Ese bucle no es replicado y por tanto no se incorpora en las nuevas hebras de DNA sintetizadas (Figura 51).

El oligonucleótido además de ser diseñado para eliminar una pequeña porción de la secuencia nucleotídica de zfMOR también se diseñó para introducir dos cambios nucleotídicos en su secuencia, generando un sitio de corte para la enzima de restricción SalI (Figura 52). Se evitó que esos dos cambios modificaran la secuencia aminoacídica de zfMOR, esto es más fácil de lograr modificando la tercera base de lo que en el mensajero serán los codones (regla del balanceo) (Crick, 1966). Esto nos permitirá posteriormente una rápida forma de discriminar entre los plásmidos con la deleción y aquellos que no la tienen. 


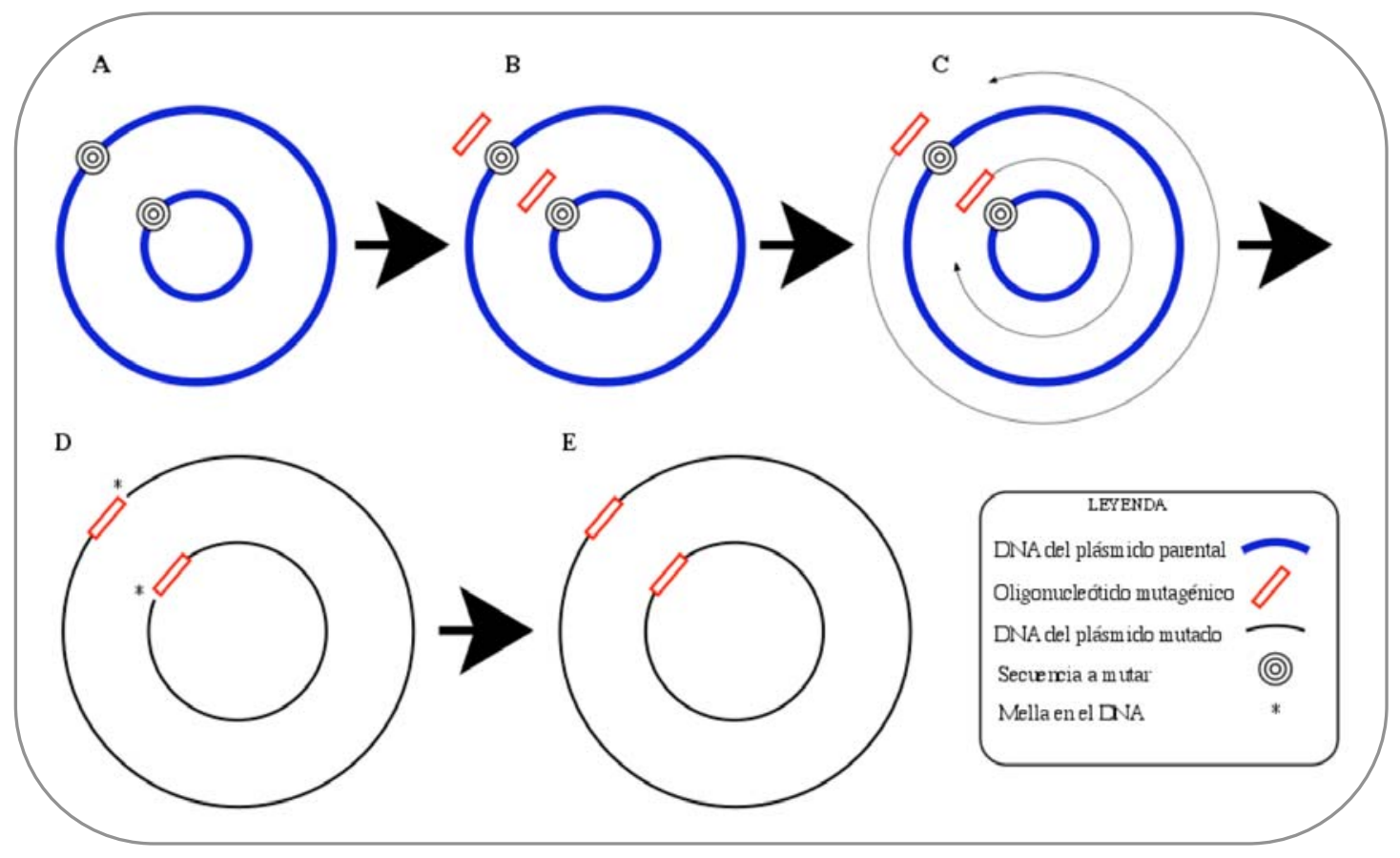

Figura 51: Esquema del proceso de mutagénesis dirigida (site-directed mutagenesis) de un plásmido. (A) Plásmido de DNA bicatenario donde se localiza la zona que se quiere mutar. (B) Los oligonucleótidos anillan en la zona donde se quiere mutar generándose algún desapareamiento. (C) La polimerasa amplifica a partir de los extremos 3' de los oligonucleótidos generándose una copia en la que está presente la mutación. Tras la amplificación la digestión con la enzima DpnI eliminará los plásmidos parentales. (D) La polimerasa no tiene capacidad de formar el último enlace fosfodiéster por lo que el plásmido sintetizado tiene una mella. (E) Tras la transformación en bacterias súper competentes, la actividad ligasa de las mismas reparará la mella.

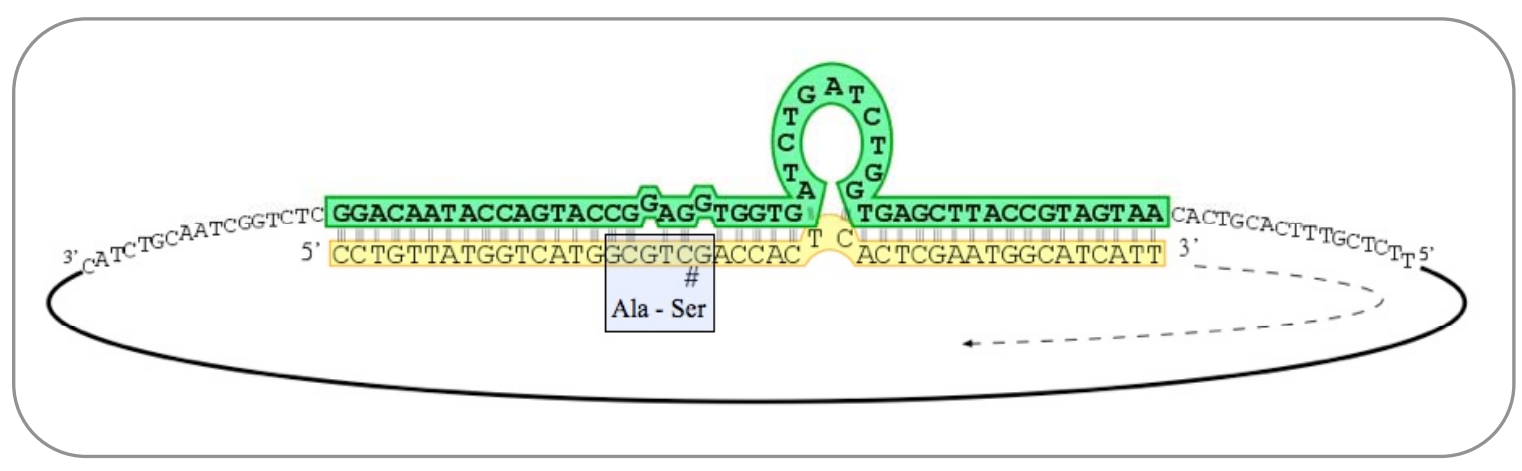

Figura 52: Esquema en el que se puede ver la secuencia del oligonucleótido diseñado para hacer la deleción (en amarillo) así como el apareamiento de bases que se produciría con el plásmido. Se puede ver como el plásmido forma un bucle en su secuencia que, en el proceso de PCR, no sería incluido en los productos sintetizados. También se pueden observar los desapareamientos originados como consecuencia de el cambio de dos nucleótidos para generar un sito de corte para la enzima de restricción SalI. En el recuadro azul se resalta la secuencia que reconoce esta enzima, así como el punto de corte (\#). También se indican los aminoácidos codificados por los dos codones involucrados en el cambio para enfatizar que mediante este procedimiento no estamos modificando la secuencia aminoacídica del receptor. La flecha indica la dirección de la síntesis. 
Tras realizar la PCR el producto obtenido se sometió una digestión con la enzima de restricción DpnI, esta enzima va a cortar el DNA reconociendo una secuencia específica ( $5^{\prime}$-GATC-3'), pero sólo cuando ésta se encuentre metilada $\left(\mathrm{N}^{6}\right.$ Metil-adenina). Puesto que el plásmido de partida se generó en las bacterias sus bases van a presentar metilaciones procedentes de la acción de metilasas bacterianas (todas las cepas de E. coli usadas habitualmente son $\mathrm{dam}^{+}$y por tanto se pueden usar para este fin ya que presentan metilación del DNA). Por el contrario las cadenas sintetizadas en una PCR no sufren el proceso de metilación ya que se carece de la actividad metilasa en la reacción. Este paso nos permite eliminar gran parte de los plásmidos que carecen de la deleción. Una vez llevada a cabo la digestión se inactivó la enzima de restricción mediante calor y se transformó en bacterias súper competentes.

Es importante resaltar que en este punto lo que estamos introduciendo en las bacterias es DNA mellado, debido a que la polimerasa no es capaz de llevar a cabo la formación del último enlace fosfodiéster (Figura 51D). Para la reparación de esta mella será necesaria la maquinaria de las bacterias en las que se ha introducido el plásmido. Tras la transformación de las bacterias éstas se sembraron en placa para permitir el crecimiento de las mismas en colonias individualizadas. Tras seleccionar 6 colonias procedentes de la transformación con plásmidos de la construcción de zfMOR mutada con FLAG y con HA se crecieron en medio liquido para poder llevar a cabo una extracción y purificación de los plásmidos. A continuación se realizó una digestión con la enzima de restricción para la cual hemos generado un sitio de corte, SalI. Puesto que en el plásmido pcDNA3.1 existen dos sitios de corte para esta enzima, la digestión de un plásmido que no tenga la deleción, y por tanto el sitio de 
corte, originará dos fragmentos de DNA mientras que aquellos plásmidos que contengan el receptor mutado tendrán también un sitio adicional de corte generándose por tanto tres fragmentos tras la digestión (Figura 53). Como controles se digirieron los plásmidos originales, lo que nos da un patrón de dos bandas.

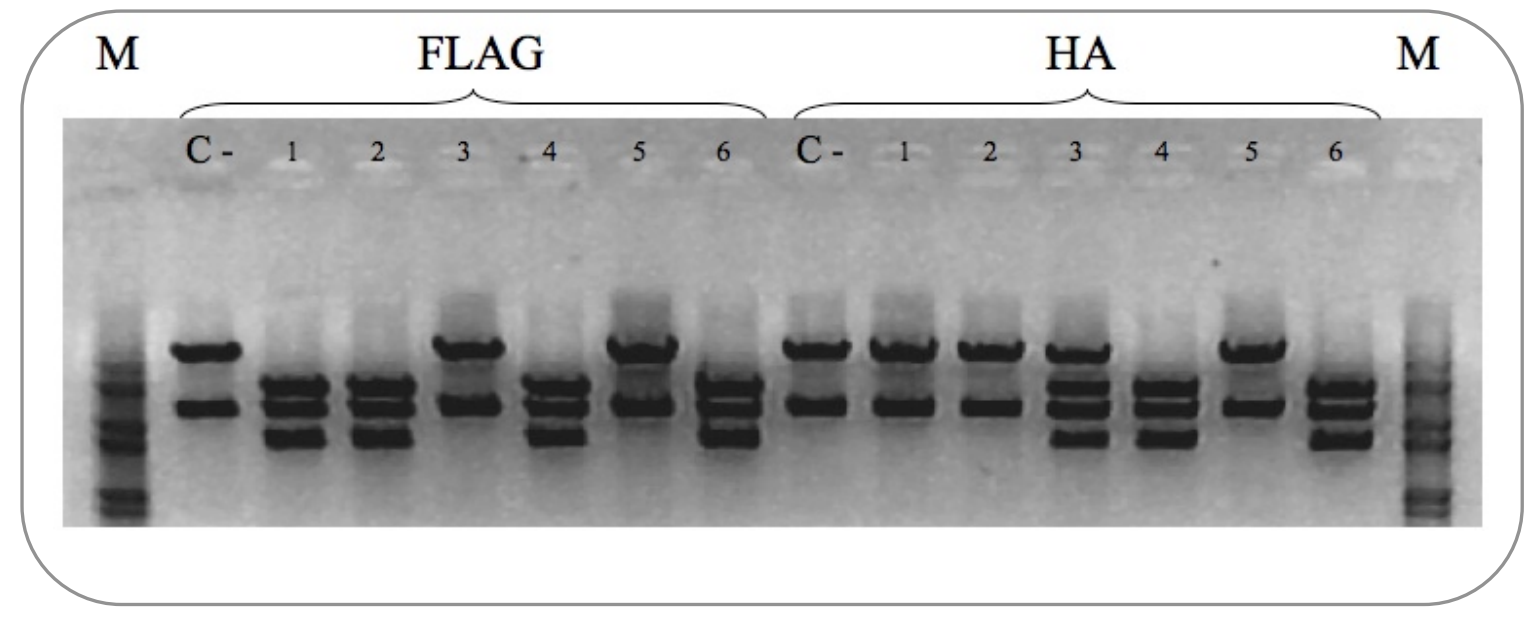

Figura 53: Patrón de digestión de los controles (C-) tanto de la construcción con FLAG como con HA, así como de los plásmidos purificados de 6 colonias de cada construcción. Se ve claramente el patrón de tres bandas correspondiente a aquellos plásmidos en los cuales se ha generado el sitio de restricción y que por tanto, presumiblemente, deben tener la deleción. En el caso de la colonia 3 de la construcción HA parece que ha adquirido tanto el plásmido delecionado como el normal, obteniéndose un patrón de 4 bandas.

\subsection{Estudio comparativo del receptor mutante y el wild type utilizando}

\section{${ }^{3}$ H-DAMGO}

Para determinar si la deleción de los tres aminoácidos en el segundo lazo extracelular variaban la capacidad de unión de distintos ligandos al receptor se llevaron a cabo experimentos de competencia o desplazamiento utilizando el compuesto mu selectivo ${ }^{3} \mathrm{H}-\mathrm{DAMGO}$. Como se pueden ver en las gráficas de la figura 54 las curvas de desplazamiento correspondientes a receptor wild type y el receptor delecionado prácticamente se solapan obteniéndose valores muy similares de $K_{i}$. En la tabla 8 se pueden ver los valores obtenidos para cada uno de los compuestos. 


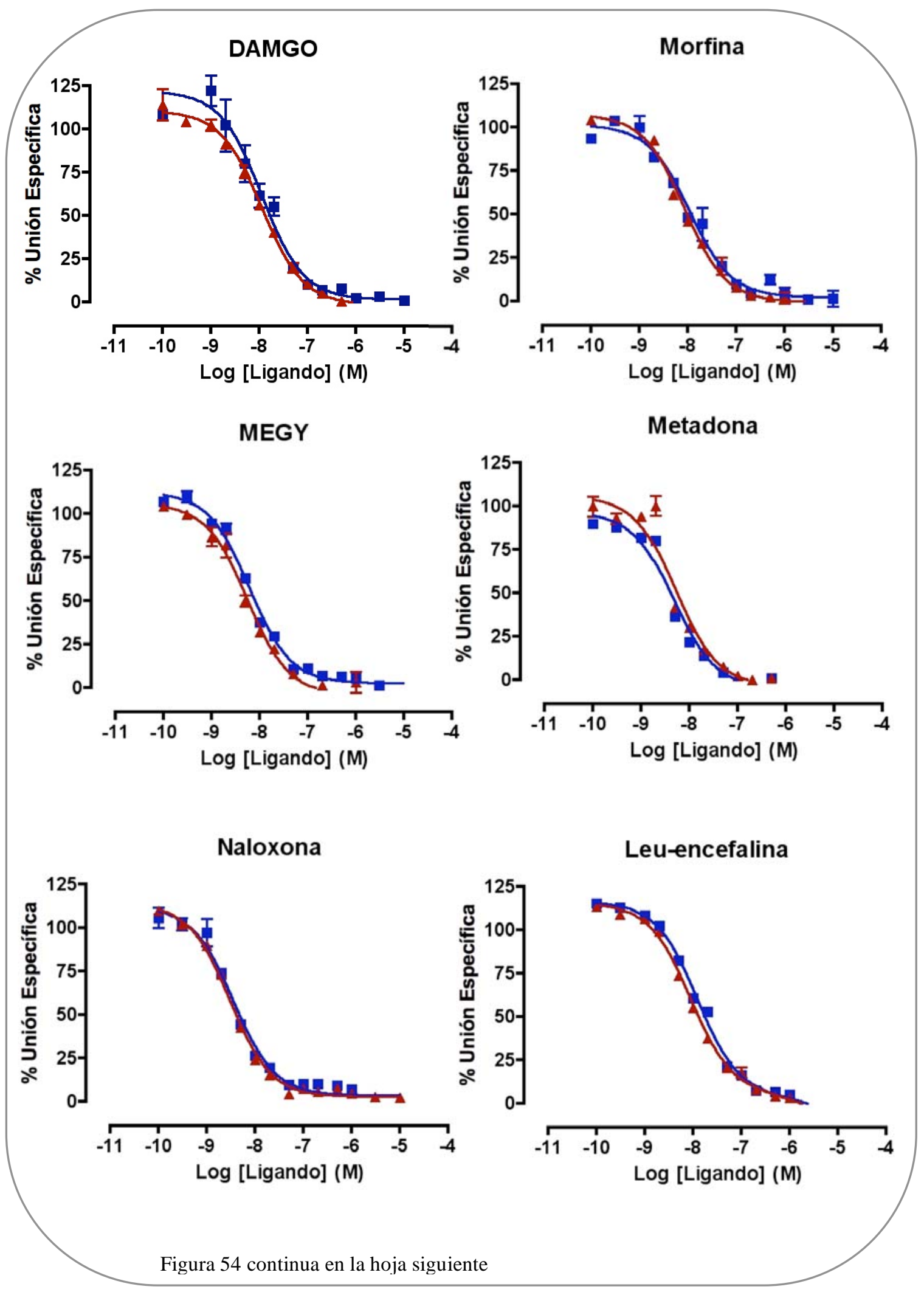



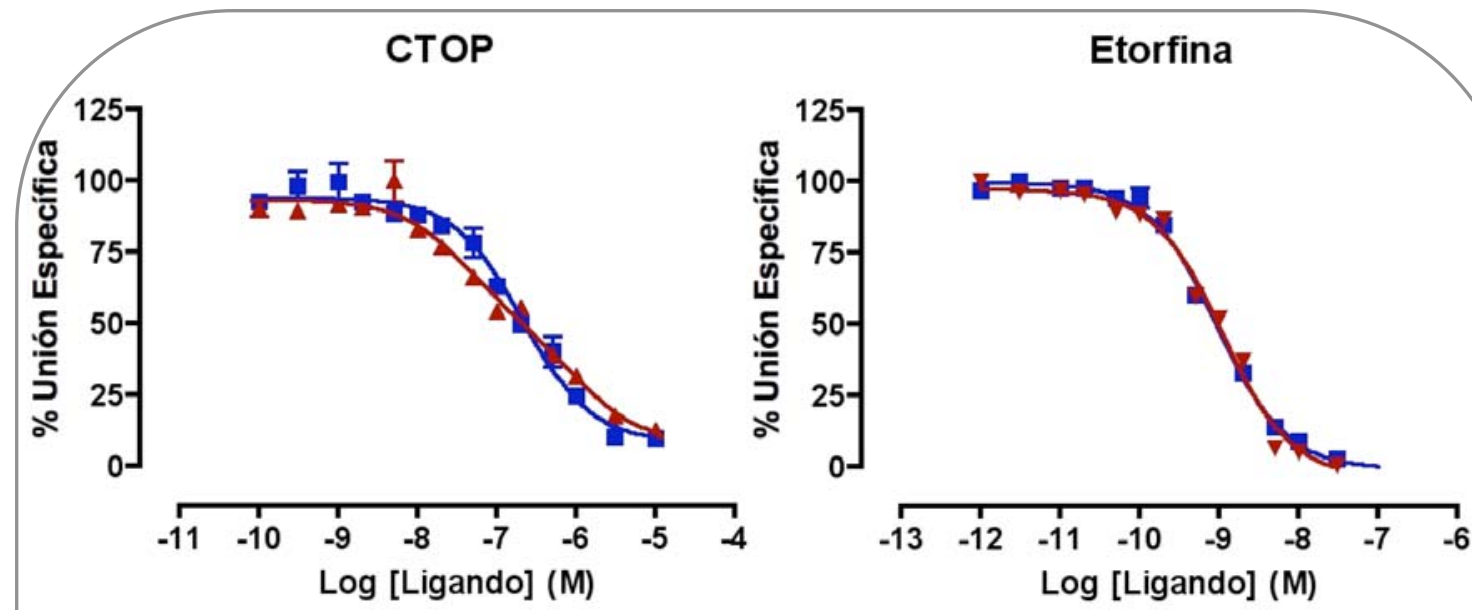

Fentanilo

Dinorfina A
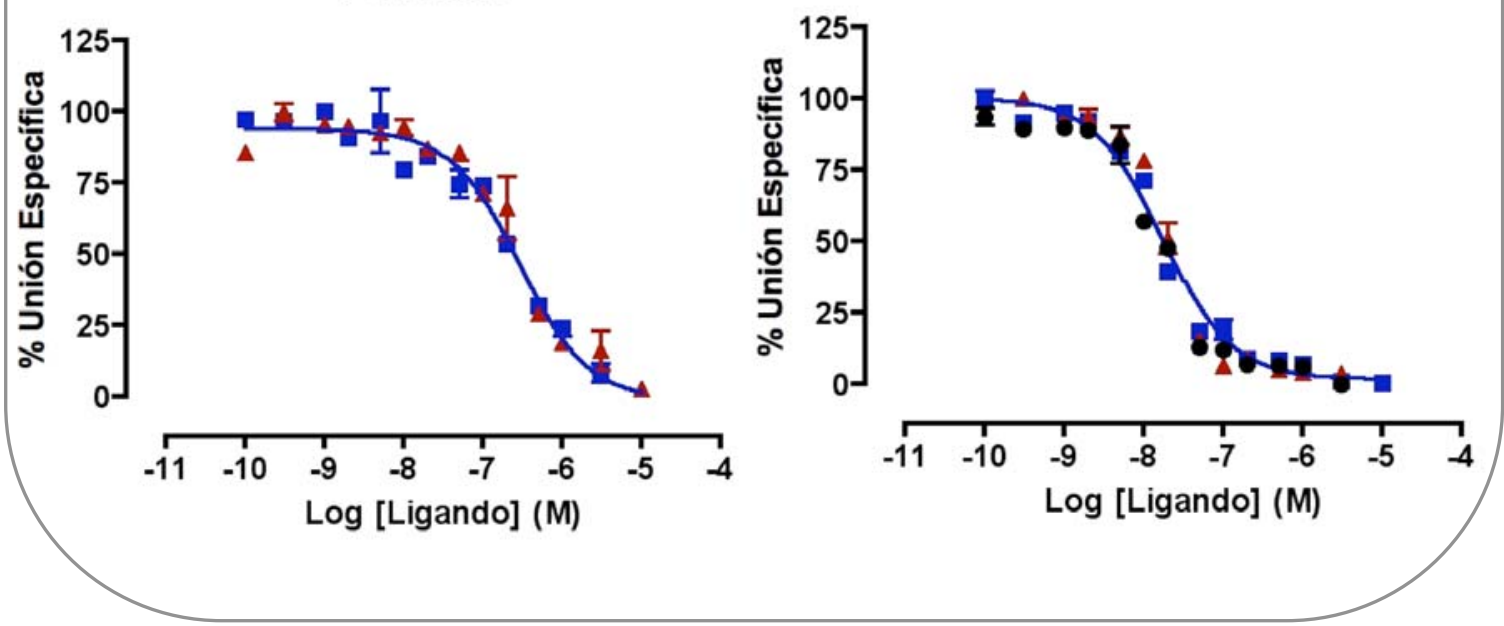

Figura 54: Curvas de desplazamiento de ${ }^{3} \mathrm{H}-\mathrm{DAMGO}$ por distintos ligandos opioides sobre extractos membranas purificadas de células HEK-293 que expresan el receptor zfMOR. Las curvas representan las medias \pm SEM de al menos tres experimentos realizados por triplicado. En azul se representa el receptor wild type y en rojo el receptor mutante.

\begin{tabular}{|c|c|c|}
\cline { 2 - 3 } \multicolumn{1}{c|}{} & \multicolumn{2}{c|}{ Afinidad Ki (nM) } \\
\cline { 2 - 3 } \multicolumn{1}{c|}{} & Wild Type & Mutante \\
\hline DAMGO & $4.8 \pm 0.8$ & $5.4 \pm 0.3$ \\
\hline Morfina & $7.9 \pm 1.9$ & $5.1 \pm 0.7$ \\
\hline Naloxona & $1.9 \pm 0.2$ & $1.6 \pm 0.2$ \\
\hline Leu-encefalina & $6.0 \pm 0.1$ & $4.3 \pm 0.1$ \\
\hline MEGY & $2.6 \pm 0.09$ & $2.3 \pm 0.1$ \\
\hline Metadona & $2.0 \pm 0.02$ & $2.3 \pm 0.1$ \\
\hline CTOP & $100 \pm 14$ & $71 \pm 10$ \\
\hline Dinorfina A & $9.3 \pm 0.6$ & $8.0 \pm 0.6$ \\
\hline Etorfina & $0.4 \pm 0.04$ & $0.5 \pm 0.004$ \\
\hline Fentanilo & $155 \pm 7$ & $*$ \\
\hline
\end{tabular}

Tabla 8: Valores de afinidad expresados como $\mathrm{K}_{\mathrm{i}}$ obtenidos en los experimentos de competencia utilizando ${ }^{3} \mathrm{H}$ DAMGO. Los valores representan las medias \pm SEM de al menos tres experimentos realizados por triplicado. El asterisco indica que el programa no es capaz de ajustar la curva. 


\subsection{Estudio comparativo del receptor mutante y el wild type utilizando}

\section{AMPc}

Continuando con el estudio comparativo del receptor wild type y el receptor delecionado se utilizaron tres compuestos que se unen al receptor opioide mu, la morfina, el DAMGO, fentanilo y el agonista no selectivo, la etorfina (Figura 55). Se puede observar como en el caso de DAMGO hay una ligera diferencia en la posición de las curvas produciéndose un desplazamiento hacia la izquierda en el caso del receptor delecionado, sin embargo esta diferencia no llega a ser ni de un orden de magnitud por lo que a nivel farmacológico no se tiene en cuenta.
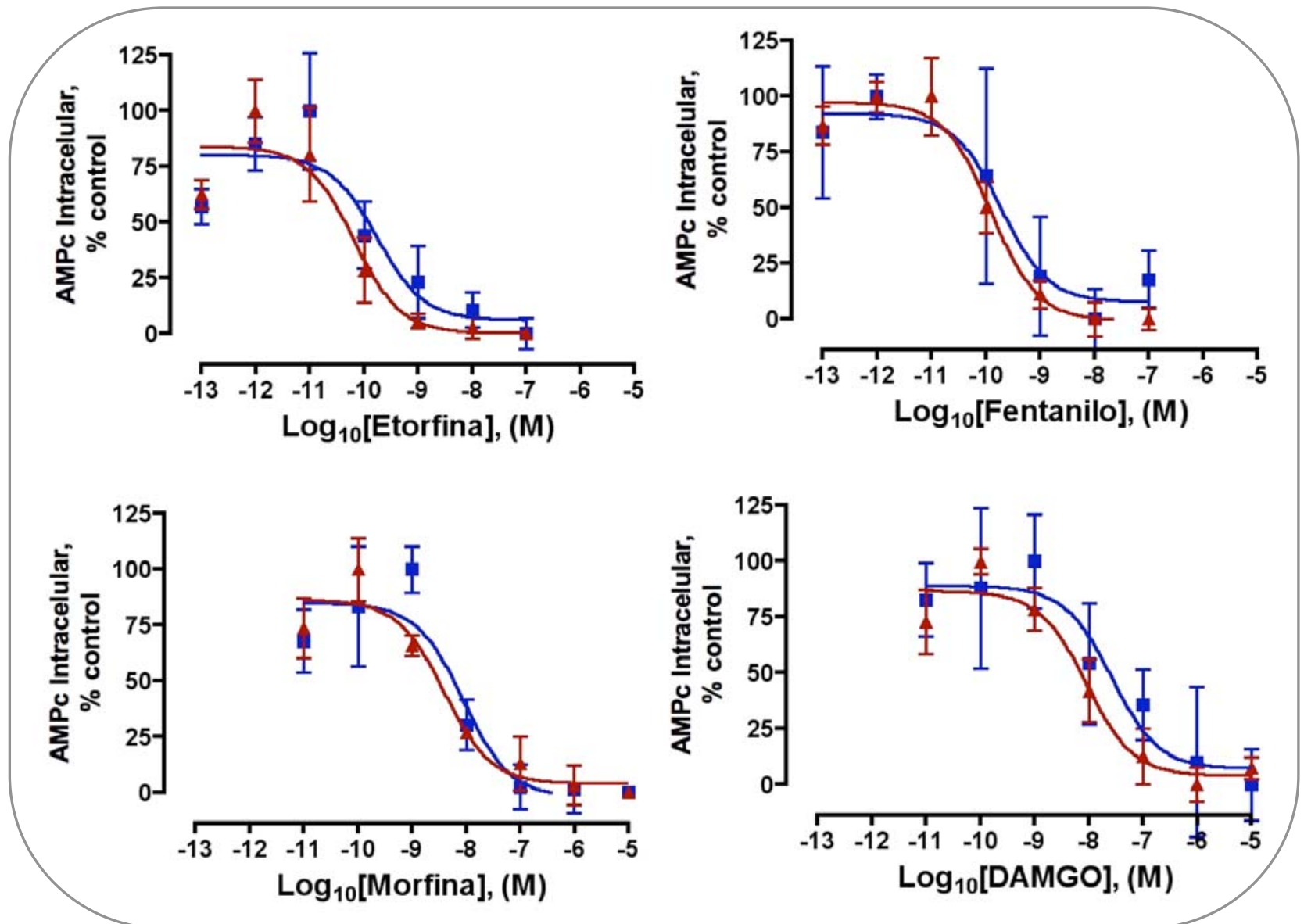

Figura 55: Curvas dosis-respuesta de la inhibición de la actividad de la adenilato ciclasa utilizando distintos ligandos en células HEK-293 transfectadas de forma estable con el receptor zfMOR y con el receptor mutante. Las curvas representan la media de tres experimentos independientes realizados por triplicado. Las barras de error representan el error estándar de la media (SEM) de los datos normalizados. En azul se encuentra el receptor wild type y en rojo el mutante 


\subsection{Estudio comparativo del receptor mutante $\mathrm{y}$ el wild type usando}

\section{ligandos endógenos}

También llevamos a cabo un estudio utilizando ligandos endógenos del pez cebra como el péptido MEGY o la dinorfina A. También utilizamos un derivado sintético de MEGY, el D-Ala-MEGY, más resistente a la degradación por peptidasas y la dinorfina humana como comparación (Figura 56). Se observa como MEGY no produce una inhibición de la adenilato ciclasa obteniéndose valores de EC50 del orden micromolar. La D-Ala-MEGY presenta valores de EC50 inferiores que pueden ser debidos a una mayor estabilidad de la estructura. Encontramos diferencias entre las acción de la dinorfinas A humanas y de pez, siendo ésta última la que presenta una mayor actividad. En la tabla 9 se pueden observar los valores obtenidos de $\mathrm{EC}_{50}$ para cada uno de los compuestos.

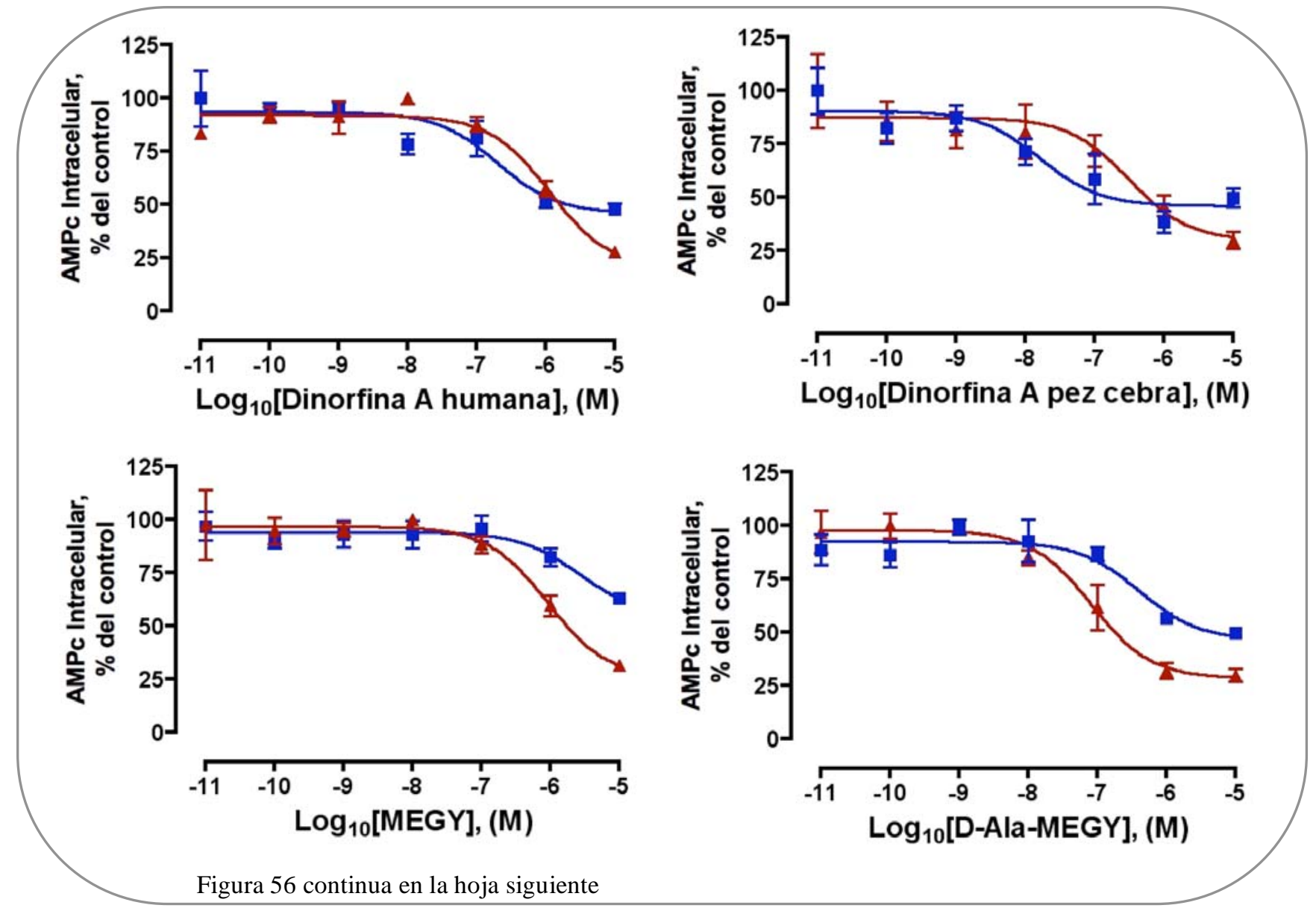




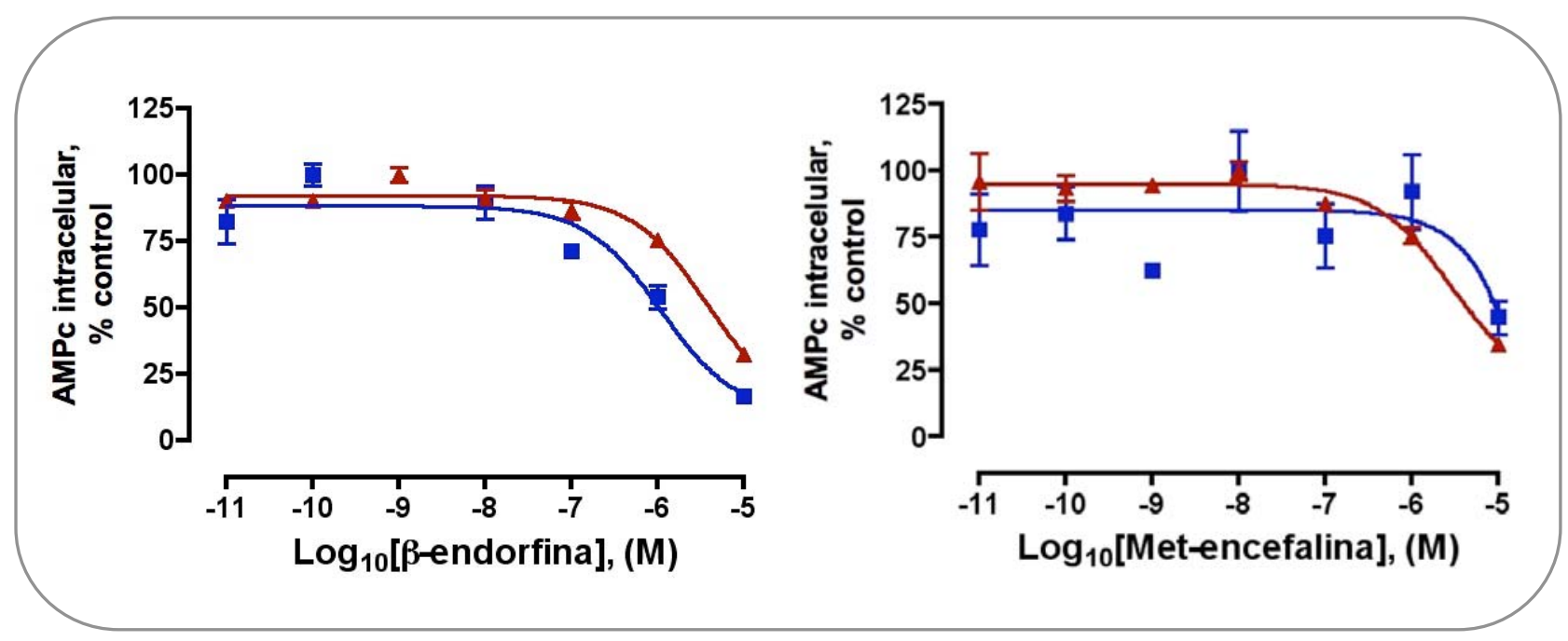

Figura 56: Curvas dosis-respuesta de la inhibición de la actividad de la adenilato ciclasa utilizando distintos ligandos en células HEK-293 transfectadas de forma estable con el receptor zfMOR y con el receptor mutante. Las curvas representan la media de tres experimentos independientes realizados por triplicado. Las barras de error representan el error estándar de la media (SEM) de los datos normalizados. En azul se encuentra el receptor wild type y en rojo el mutante.

\begin{tabular}{|c|c|c|}
\cline { 2 - 3 } \multicolumn{1}{c|}{} & \multicolumn{2}{c|}{ Eficacia EC50 (nM) } \\
\cline { 2 - 3 } \multicolumn{1}{c|}{} & Wild Type & Mutante \\
\hline MEGY & $3692 \pm *$ & $656 \pm 116$ \\
\hline D-Ala-MEGY & $306 \pm 116$ & $57 \pm 16$ \\
\hline Dinorfina A (humana) & $240 \pm 131$ & $1240 \pm 420$ \\
\hline Dinorfina A (pez cebra) & $31 \pm 15$ & $401 \pm 76$ \\
\hline Met-encefalina & $596 \pm 187$ & $2974 \pm 457$ \\
\hline$\beta$-endorfina & $516 \pm 263$ & $3965 \pm 701$ \\
\hline
\end{tabular}

Tabla 9: En esta tabla se muestran los valores obtenidos de EC50 en la comparación del receptor wild type y mutante en la capacidad de inhibición la producción de AMPc. El asterisco indica un error muy alto.

\subsection{Estudio de la capacidad de unión del $\mathrm{Zn}^{2+}$ al receptor zfMOR}

Se sabe que en los receptores opioides, especialmente en los receptores de tipo mu, hay una serie de aminoácidos conservados, involucrados en la unión del ligando al receptor, y que tienen la capacidad intrínseca de unir zinc con una relativamente alta afinidad (Fowler y cols., 2004). Para determinar la presencia o no de esta estructura en el receptor zfMOR, llevamos a cabo un experimento en el cual se midió la capacidad de unión de la ${ }^{3} \mathrm{H}$ diprenorfina al receptor en presencia de distintas 
concentraciones de zinc. Como se puede observar en la figura 57 el zinc dificulta la unión de la diprenorfina a medida que aumentamos su concentración. También se puede observar como no se encuentran diferencias entre el comportamiento de el receptor wild type y el mutante.

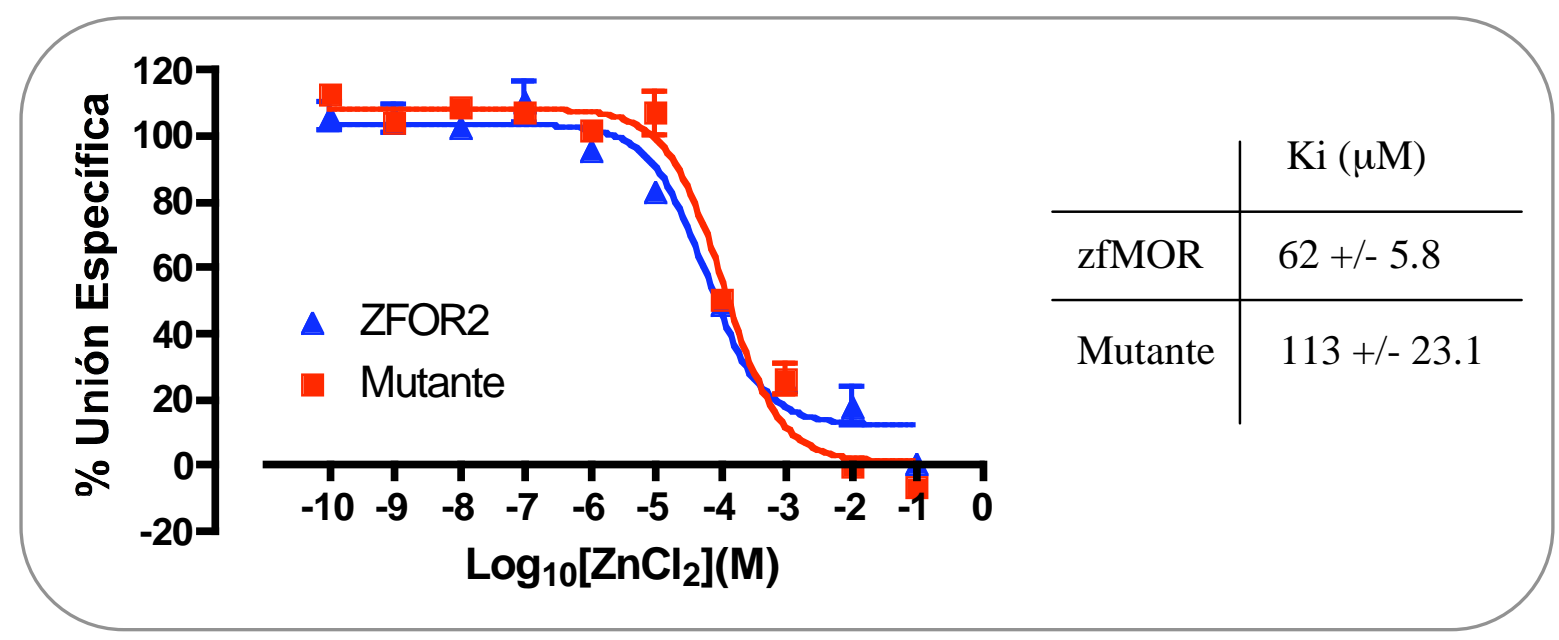

Figura 57: En la gráfica se puede observar el efecto del zinc sobre la unión del ligando tritiado diprenorfina al receptor zfMOR y al delecionado. Se ve como a medida que aumentamos la concentración de zinc se produce una reducción de la unión del radioligando a ambos receptores. La tabla nos da los valores de afinidad en forma de Ki del zinc por el receptor.

$\quad 5.15$ Estudios de internalización del receptor mediante
inmunofluorescencia

Los estudios de internalización mediante inmunofluorescencia permitieron determinar que en ausencia de un ligando opioide la gran mayoría de la fuorescencia de las células HEK trasnfectadas se encontraba en la membrana celular, salvo escasas y pequeñas vesículas que podrían corresponder con la internalización constitutiva. Esta fluorescencia de membrana se puede observar en la figura 58. El tono verdoso del interior celular correspondería a la fluorescencia emitida desde otros planos de la muestra ya que al ser microscopía de fluorescencia y no confocal no contamos con una sección óptica de la muestra. 

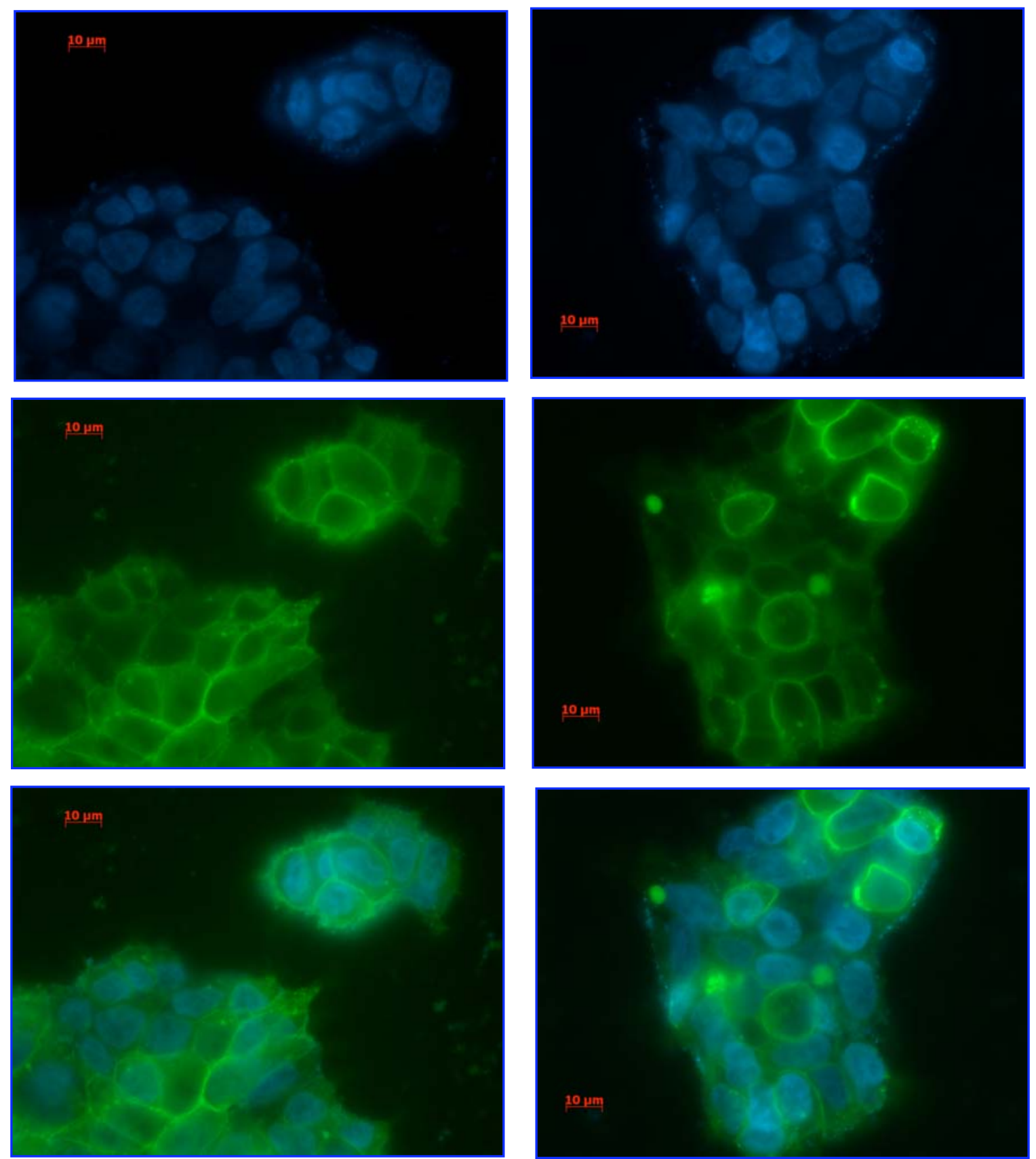

Figura 58: Inmunofluorescencia sobre células HEK293 expresando el receptor zfMOR con el epítopo HA en su extremo amino terminal. Las fotografías se tomaron con un microscopio de fluorescencia invertido utilizando filtros para fluoresceína y Hoechst. En la primera fila se observan los núcleos celulares teñidos con Hoechst; en la segunda fila detectamos la presencia del receptor zfMOR en la membrana celular mediante la utilización del anticuerpo anti HA directamente conjugado con fluoresceína y en la tercera fila la superposición de ambas imágenes.

Control sin tratamiento.

Cuando realizamos un tratamiento a las células de $30 \mathrm{~min}$. utilizando el agonista DAMGO a una concentración final de $1 \mu \mathrm{M}$ (Figura 59) podemos observar 
como parte de la fluorescencia de membrana pasa a formar pequeñas vesículas en un característico patrón punteado en el interior celular. Este resultado aunque una información clara sobre la capacidad de internalización del DAMGO sobre el receptor zfMOR es difícil de cuantificar y está sujeto a subjetividad.
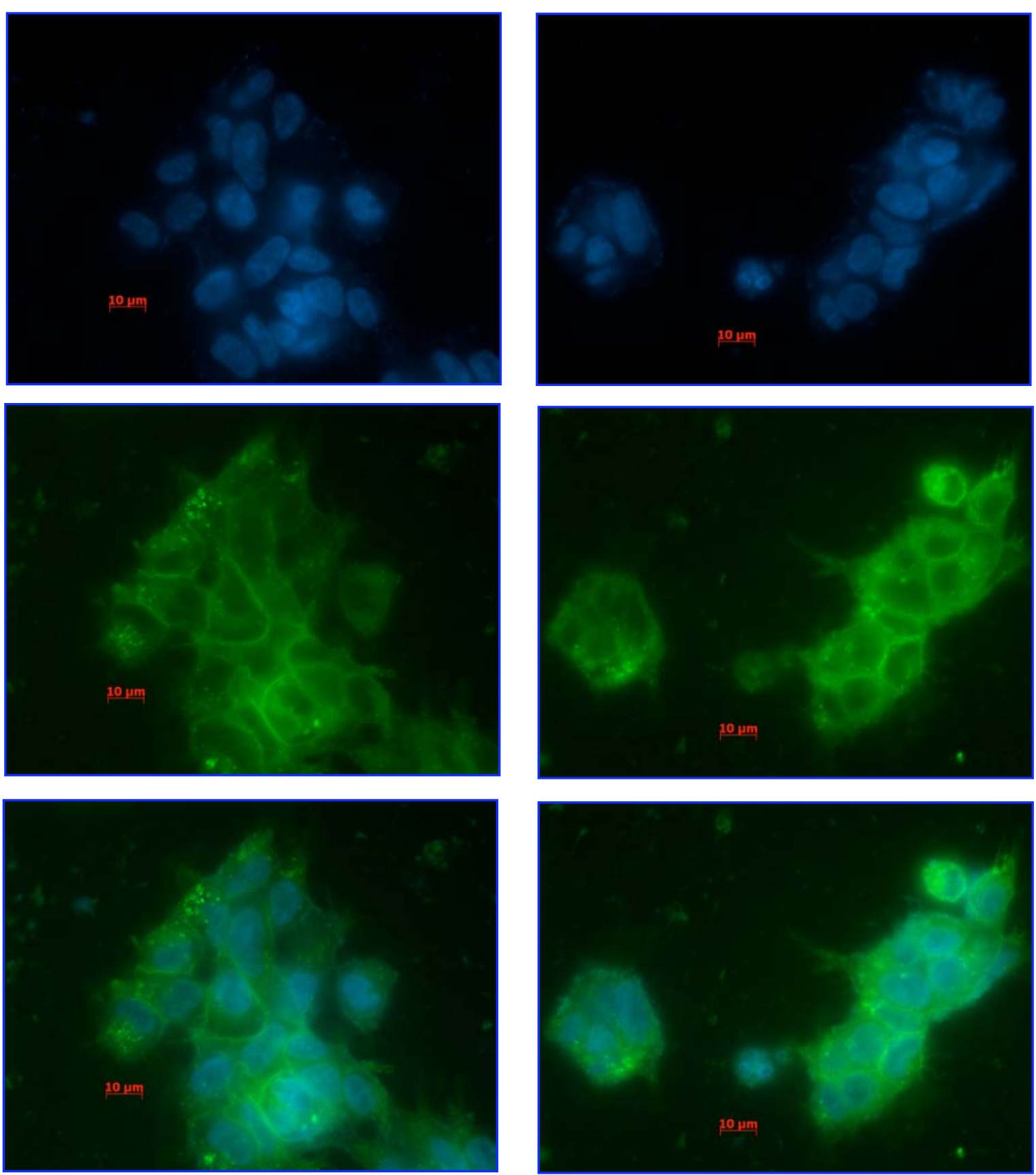

Figura 59: Inmunofluorescencia sobre células HEK293 expresando el receptor zfMOR con el epítopo HA en su extremo amino terminal. Las fotografías se tomaron con un microscopio de fluorescencia invertido utilizando filtros para fluoresceína y Hoechst. En la primera fila se observan los núcleos celulares teñidos con Hoechst; en la segunda fila detectamos la presencia del receptor ZFOR2 en la membrana celular mediante la utilización del anticuerpo anti HA directamente conjugado con fluoresceína y en la tercera fila la superposición de ambas imágenes.

Tratamiento: DAMGO $1 \mu \mathrm{M}, 30 \mathrm{~min} ., 37^{\circ} \mathrm{C}$. 
Un resultado similar obtenemos con el tratamiento de etorfina $(30 \mathrm{~min}$.

etorfina $1 \mu \mathrm{M}$ ) aunque en este caso parece que el patrón de puntos intracelulares es un poco mayor (Figura 60).
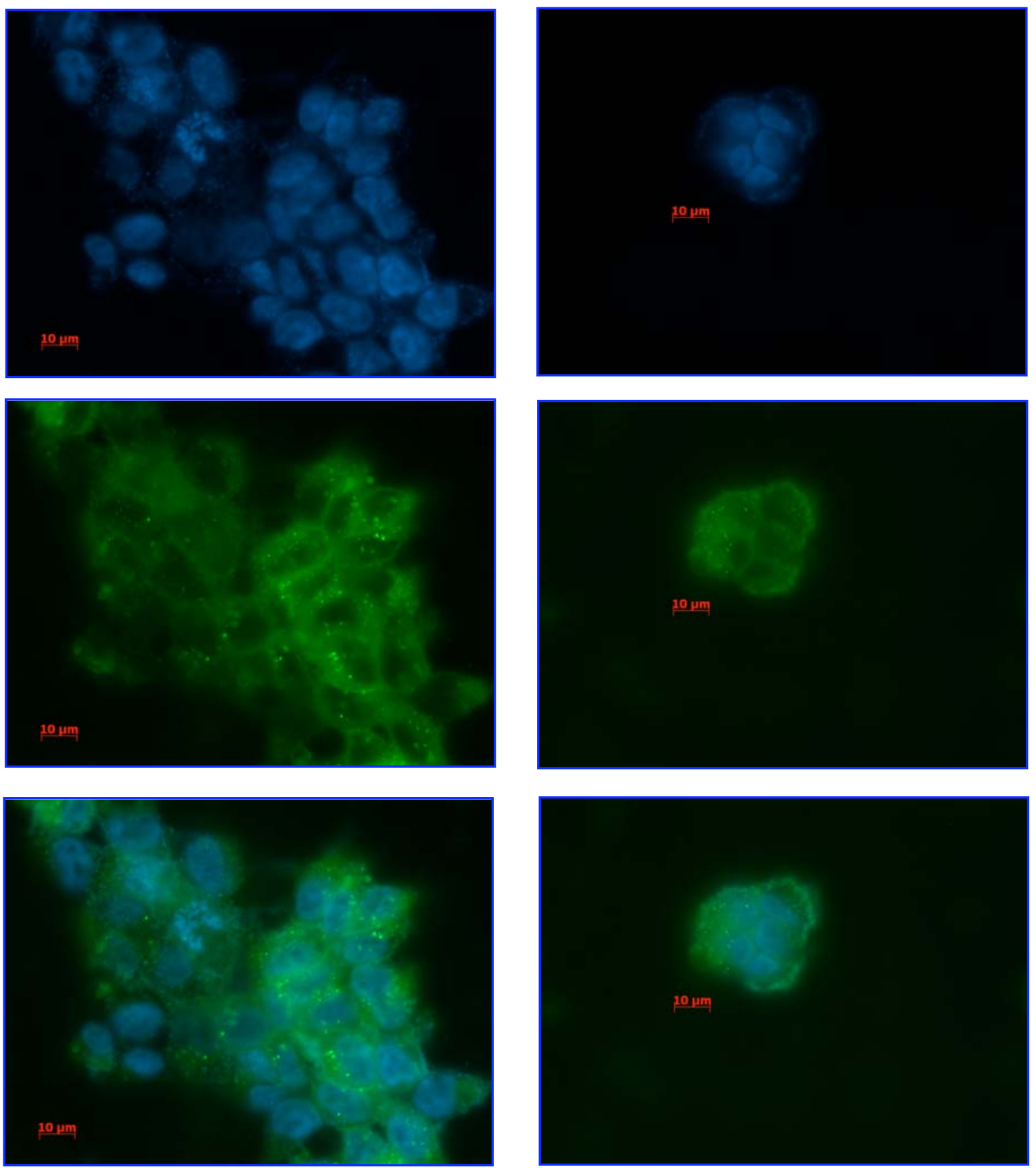

Figura 60: Esta figura muestra la inmunofluorescencia sobre células HEK293 expresando el receptor zfMOR con el epítopo HA en su extremo amino terminal. Las fotografías se tomaron con un microscopio de fluorescencia invertido utilizando filtros para fluoresceína y Hoechst. En la primera fila se observan los núcleos celulares teñidos con Hoechst; en la segunda fila detectamos la presencia del receptor zfMOR en la membrana celular mediante la utilización del anticuerpo anti HA directamente conjugado con fluoresceína y en la tercera fila la superposición de ambas imágenes.

Tratamiento: Etorfina $1 \mu \mathrm{M}, 30 \mathrm{~min} ., 37^{\circ} \mathrm{C}$. 
Como método de control interno utilizamos el receptor mu de rata transfectado en células HEK-293 y llevamos a cabo los experimentos de forma paralela.
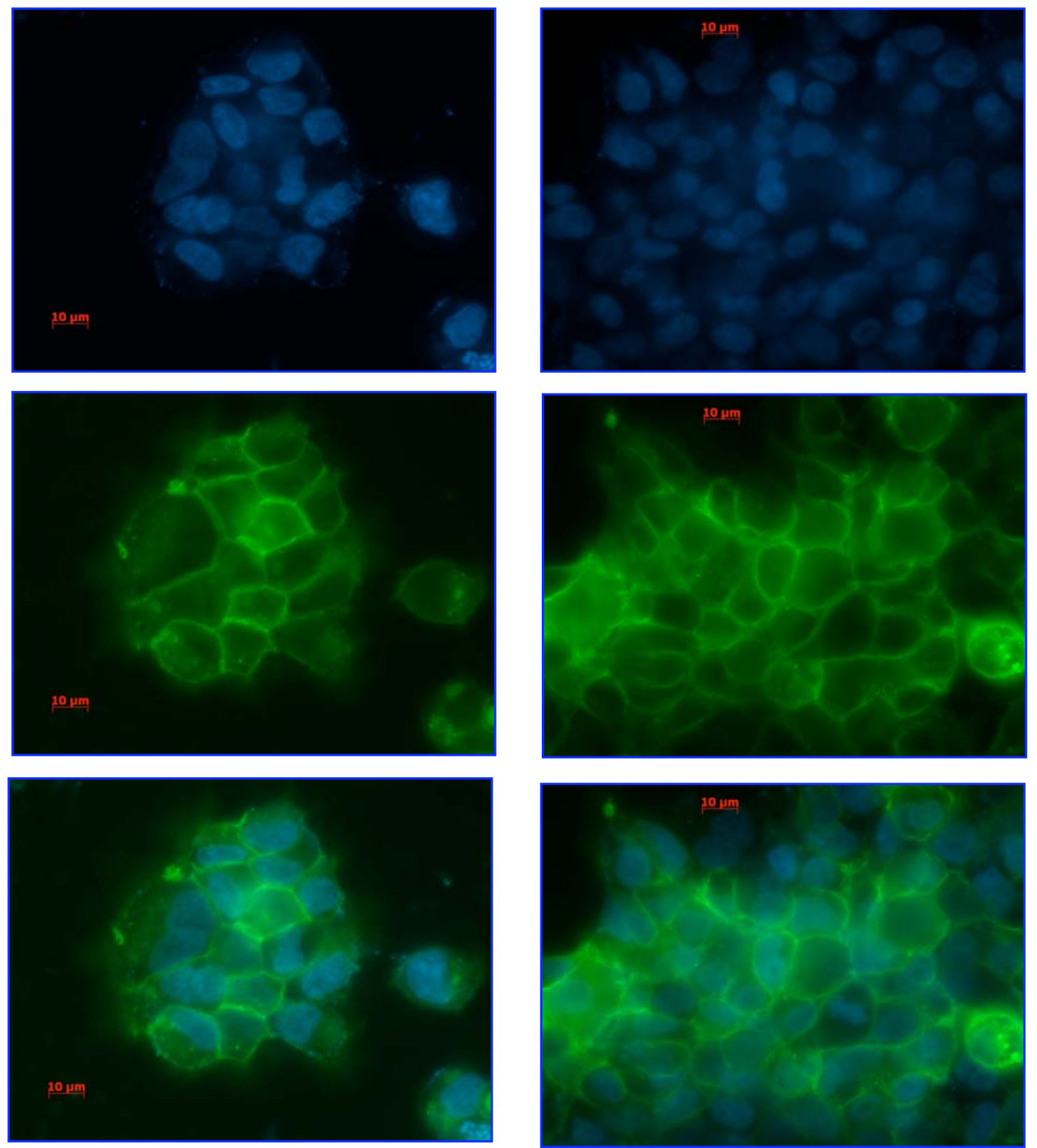

Figura 61: Inmunofluorescencia sobre células HEK293 expresando el receptor mu de rata con el epítopo HA en su extremo amino terminal. Las fotografías se tomaron con un microscopio de fluorescencia invertido utilizando filtros para fluoresceína y Hoechst. En la primera fila se observan los núcleos celulares teñidos con Hoechst; en la segunda fila detectamos la presencia del receptor en la membrana celular mediante la utilización del anticuerpo anti HA directamente conjugado con fluoresceína y en la tercera fila la superposición de ambas imágenes.

Control sin tratamiento. 
$\mathrm{Al}$ igual que en el caso del receptor zfMOR en ausencia de ligando opioide

la fluorescencia se concentra en la membrana citoplasmática permitiendo una vista clara del contorno celular (Figura 61).
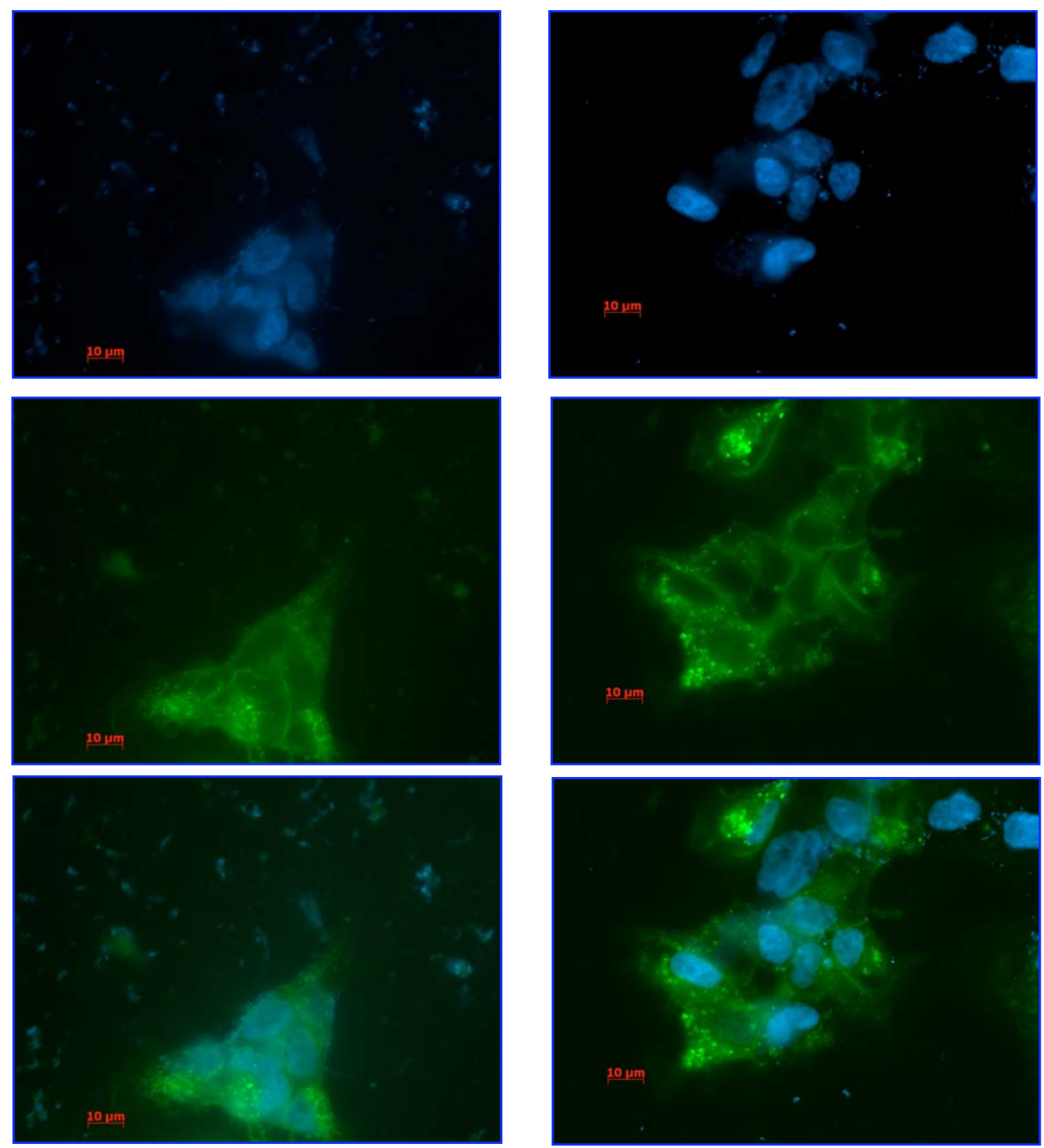

Figura 62: Inmunofluorescencia sobre células HEK293 expresando el receptor mu de rata con el epítopo HA en su extremo amino terminal. Las fotografías se tomaron con un microscopio de fluorescencia invertido utilizando filtros para fluoresceína y Hoechst. En la primera fila se observan los núcleos celulares teñidos con Hoechst; en la segunda fila detectamos la presencia del receptor en la membrana celular mediante la utilización del anticuerpo anti HA directamente conjugado con fluoresceína y en la tercera fila la superposición de ambas imágenes.

Tratamiento: DAMGO $1 \mu \mathrm{M}, 30 \mathrm{~min} ., 37^{\circ} \mathrm{C}$. 
Cuando realizamos un tratamiento con DAMGO perdemos ligeramente el contorno celular y encontramos puntos de fluorescencia concentrados en el interior celular y que corresponden con las vesículas de endocitosis (Figura 62).
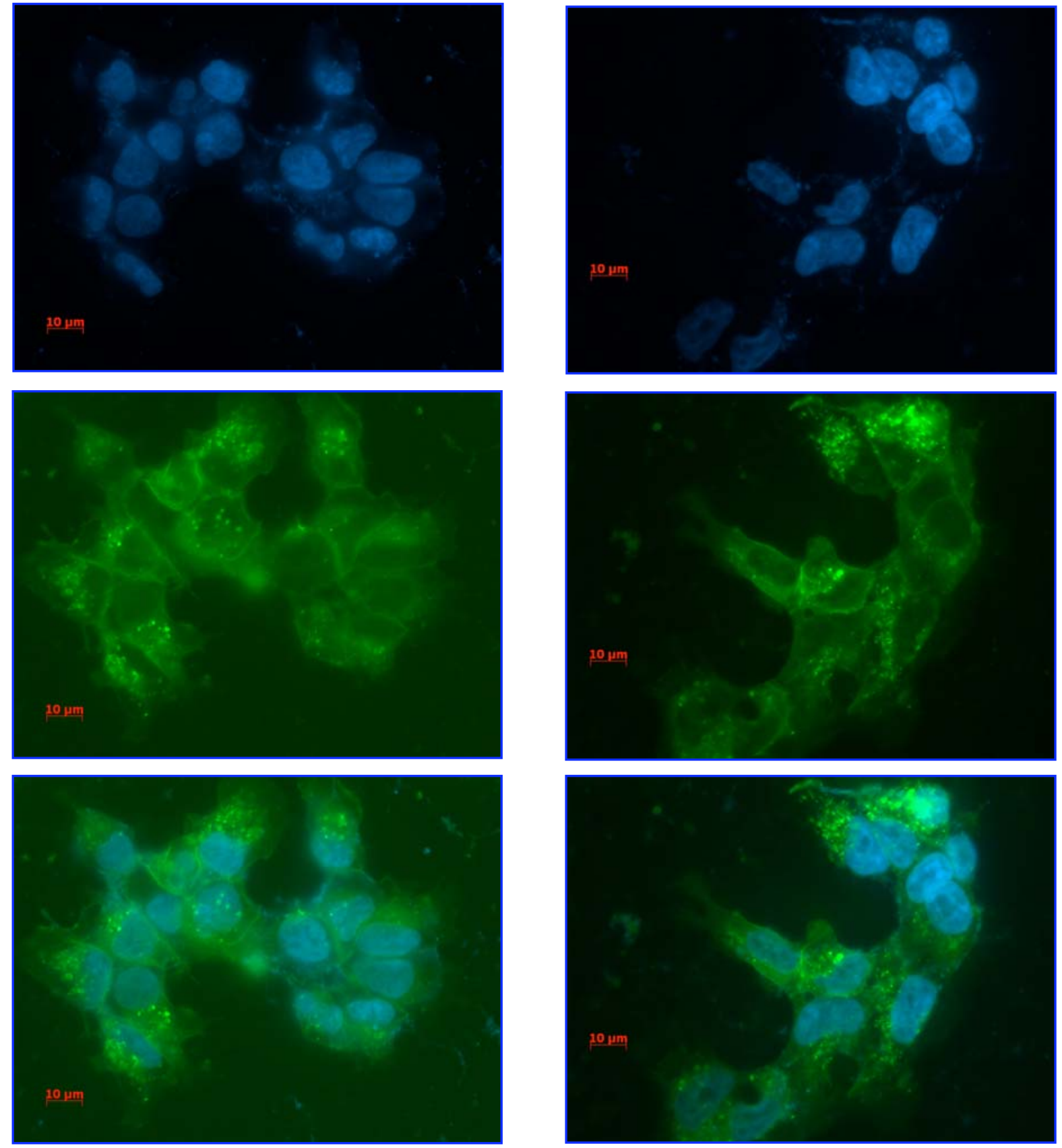

Figura 63: Inmunofluorescencia sobre células HEK293 expresando el receptor mu de rata con el epítopo HA en su extremo amino terminal. Las fotografías se tomaron con un microscopio de fluorescencia invertido utilizando filtros para fluoresceína y Hoechst. En la primera fila se observan los núcleos celulares teñidos con Hoechst; en la segunda fila detectamos la presencia del receptor en la membrana celular mediante la utilización del anticuerpo anti HA directamente conjugado con fluoresceína y en la tercera fila la superposición de ambas imágenes.

Tratamiento: Etorfina $1 \mu \mathrm{M}, 30 \mathrm{~min} ., 37^{\circ} \mathrm{C}$. 
De igual manera que en el caso de DAMGO un tratamiento con etorfina

produce la internalización del receptor en vesículas (Figura 63).
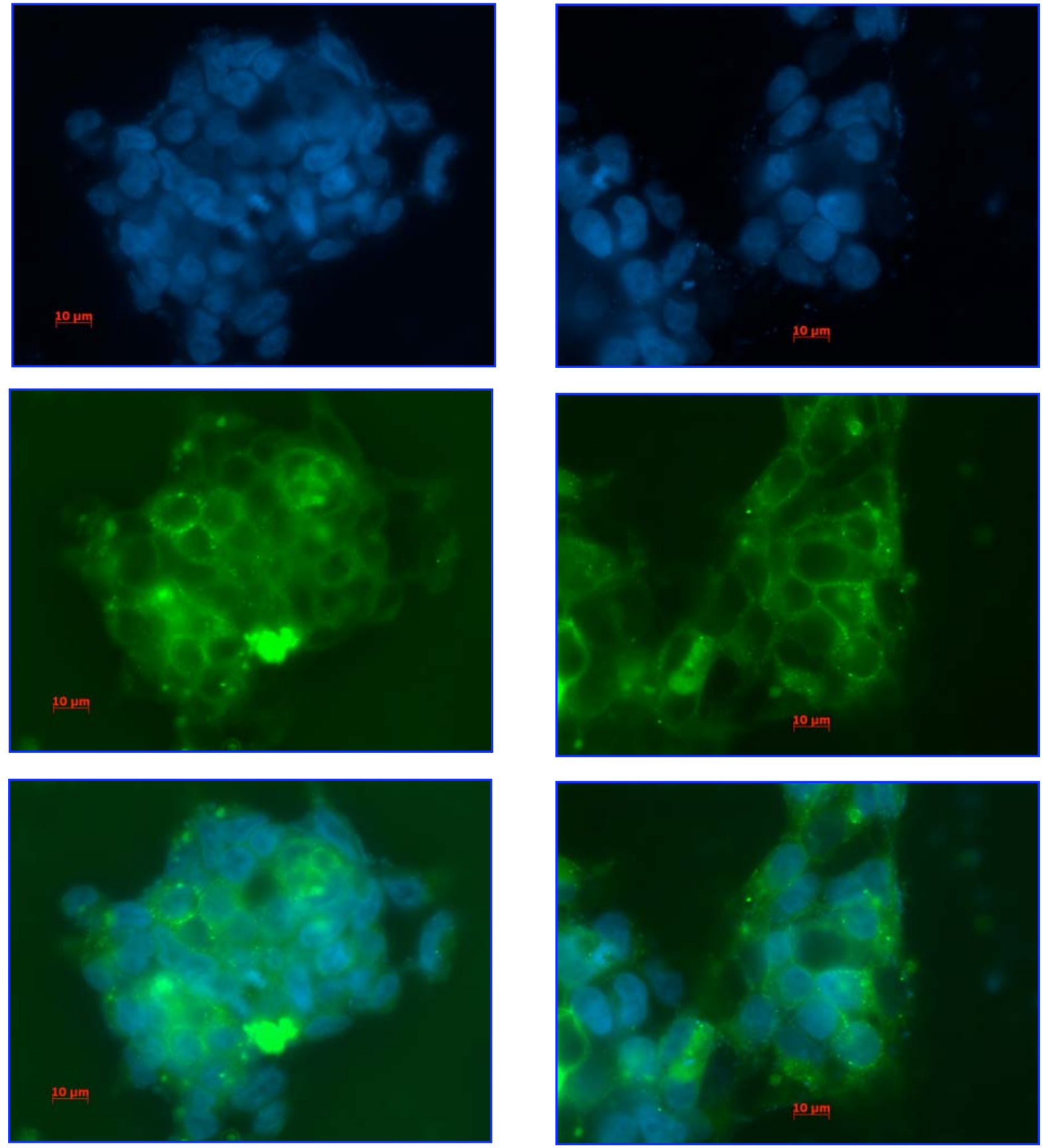

Figura 64: Inmunofluorescencia sobre células HEK293 el receptor mu de pez cebra (imágenes de la derecha) y expresando el receptor mu de rata con el epítopo HA (imágenes de la izquierda). Las fotografías se tomaron con un microscopio de fluorescencia invertido utilizando filtros para fluoresceína y Hoechst. En la primera fila se observan los núcleos celulares teñidos con Hoechst; en la segunda fila detectamos la presencia del receptor en la membrana celular mediante la utilización del anticuerpo anti HA directamente conjugado con fluoresceína y en la tercera fila la superposición de ambas imágenes.

Tratamiento: Met-encefalina $1 \mu \mathrm{M}, 30 \mathrm{~min} ., 37^{\circ} \mathrm{C}$. 
Otros compuestos utilizados para los ensayos de internalización por inmunofluorescencia fueron la Met-encefalina (Figura 64) y la morfina (Figura 65).
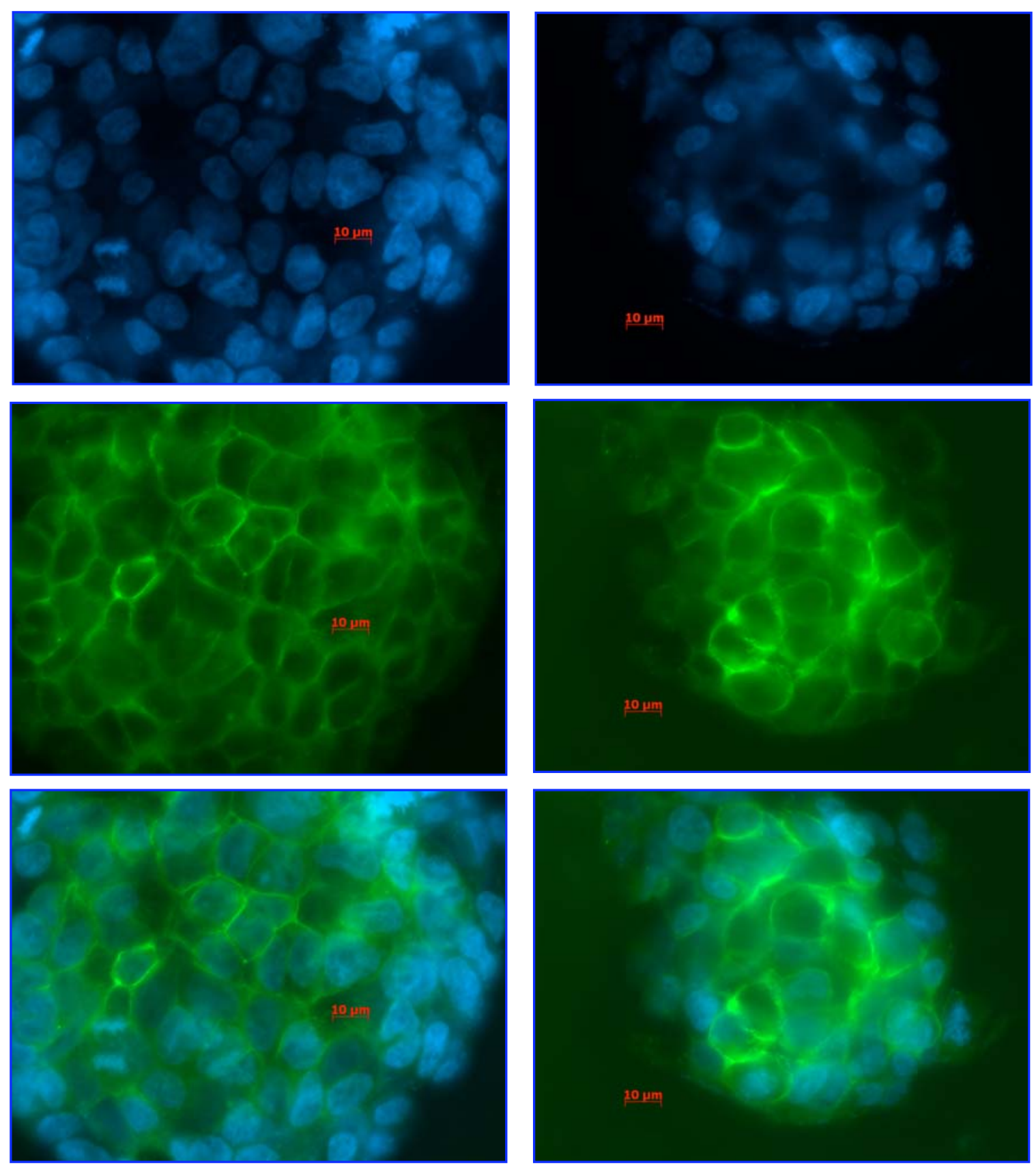

Figura 65: Inmunofluorescencia sobre células HEK293 el receptor mu de pez cebra (imágenes de la derecha) y expresando el receptor mu de rata con el epítopo HA (imágenes de la izquierda). Las fotografías se tomaron con un microscopio de fluorescencia invertido utilizando filtros para fluoresceína y Hoechst. En la primera fila se observan los núcleos celulares teñidos con Hoechst; en la segunda fila detectamos la presencia del receptor en la membrana celular mediante la utilización del anticuerpo anti HA directamente conjugado con fluoresceína y en la tercera fila la superposición de ambas imágenes.

Tratamiento: Morfina $1 \mu \mathrm{M}, 30 \mathrm{~min} ., 37^{\circ} \mathrm{C}$. 
Para completar los estudios de internalización y dado que no podemos cuantificar las fotos de inmunofluorescencia decidimos llevar a cabo el estudio de internalización por medio de la citometría de flujo lo que nos da una forma rápida y precisa de determinar los porcentajes de internalización. El primer paso que seguimos fue el de determinar la concentración óptima de anticuerpo para llevar a cabo los experimentos. La concentración recomendada en el prospecto del anticuerpo era de entre 1 a $5 \mu \mathrm{g} / \mathrm{ml}$. En nuestras condiciones pudimos observar como a mayor concentración de anticuerpo mayor era la internalización (Figura 66). Este hecho que se podría interpretar como que el anticuerpo interacciona con el receptor modificando su conformación y haciendo que se internalice tiene una explicación mucho más sencilla. Cuando utilizamos una concentración baja de anticuerpo no marcamos todos los receptores de la membrana plasmática. Tras el tratamiento los receptores se internalizarían pero al haber una gran cantidad de ellos sin marcar no podrá ser detectado. Utilizando una concentración mayor podremos marcar todos los receptores de membrana y por tanto detectar toda la internalización que ocurra como consecuencia del tratamiento. También hemos podido observar que una concentración muy elevada de anticuerpo (en nuestro caso $10 \mu \mathrm{g} / \mathrm{ml}$ ) produce una inhibición de la internalización.

Los valores para la internalización obtenidos tras un tratamiento con etorfina $1 \mu \mathrm{M}$ durante 30 min. y a $37^{\circ} \mathrm{C}$ fueron de $15 \%$ para la concentración de 1 $\mu \mathrm{g} / \mathrm{ml}$, de $19 \%$ para la concentración de $2,5 \mu \mathrm{g} / \mathrm{ml}$ y de $39 \%$ para la de $5 \mu \mathrm{g} / \mathrm{ml}$. Para los subsiguientes experimentos se utilizó esta última concentración. 


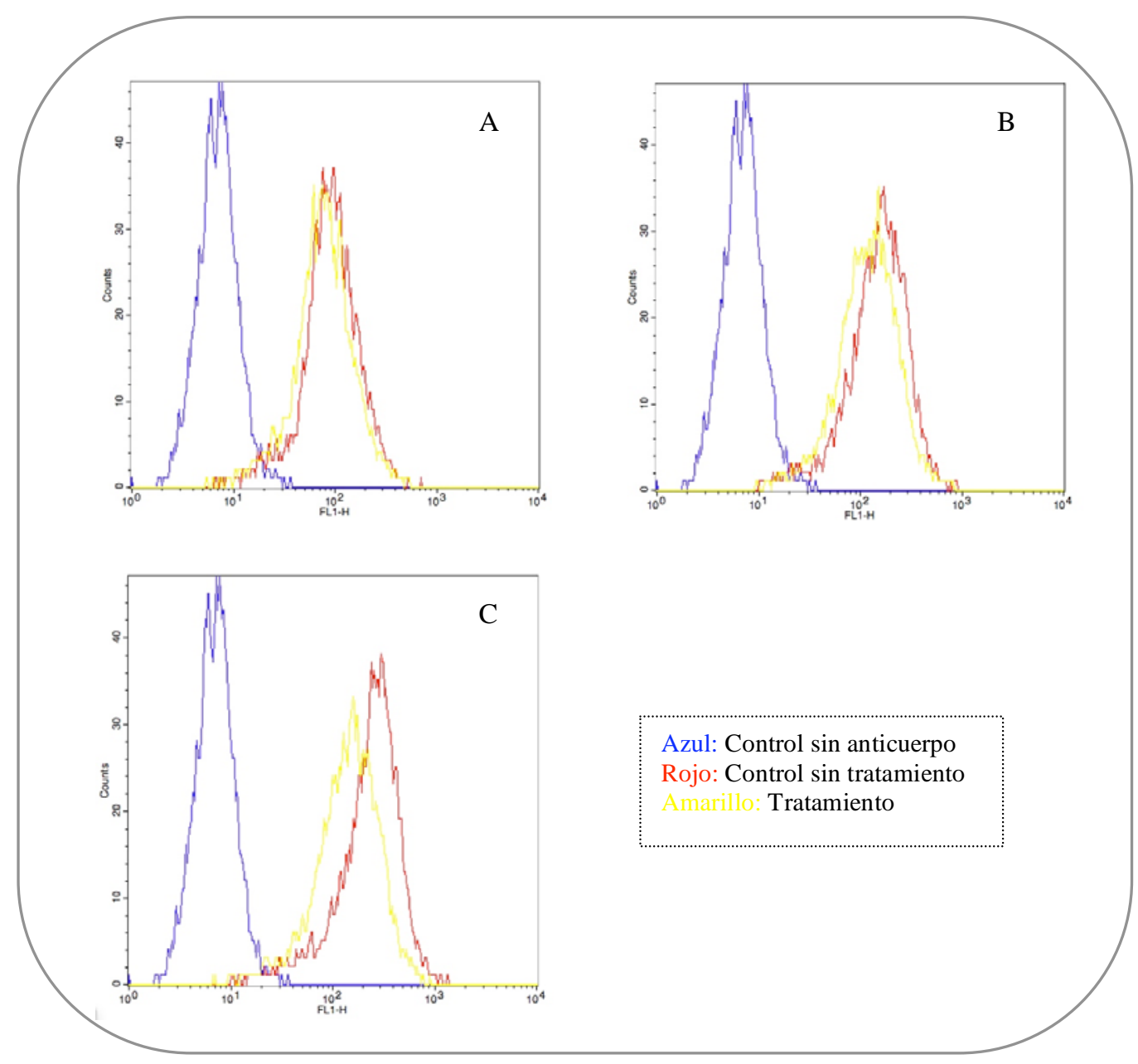

Figura 66: Puesta a punto de la concentración de anticuerpo para citometría de flujo. En los gráficos se representa el número de células o eventos (Counts) frente a la fluorescencia (FL1H). La curva azul representa el control sin anticuerpo; este valor no va a dar la posible autofluorescencia de la muestra. La curva roja corresponde con células sin tratamiento; en este caso la mayor parte de los receptores se localizaran en la membrana plasmática. La curva amarilla representa el tratamiento con la droga lo que provocará un desplazamiento de esta curva con respecto a la control (sin tratamiento) hacia la izquierda

A: Concentración de anticuerpo $1 \mu \mathrm{g} / \mathrm{ml}$.

B: Concentración de anticuerpo $2,5 \mu \mathrm{g} / \mathrm{ml}$.

C: Concentración de anticuerpo $5 \mu \mathrm{g} / \mathrm{ml}$.

A continuación determinamos la internalización producida por distintos compuestos. En todos los casos el tratamiento fue durante $30 \mathrm{~min}$. y con una concentración final de compuesto de $1 \mu \mathrm{M}$. En el caso de DAMGO el valor obtenido 
fue de $17 \%$. Para la etorfina fue de $39 \%$. MEGY produjo una internalización del 29

\% y la morfina no llegó al 5 \% de internalización (Figura 67).

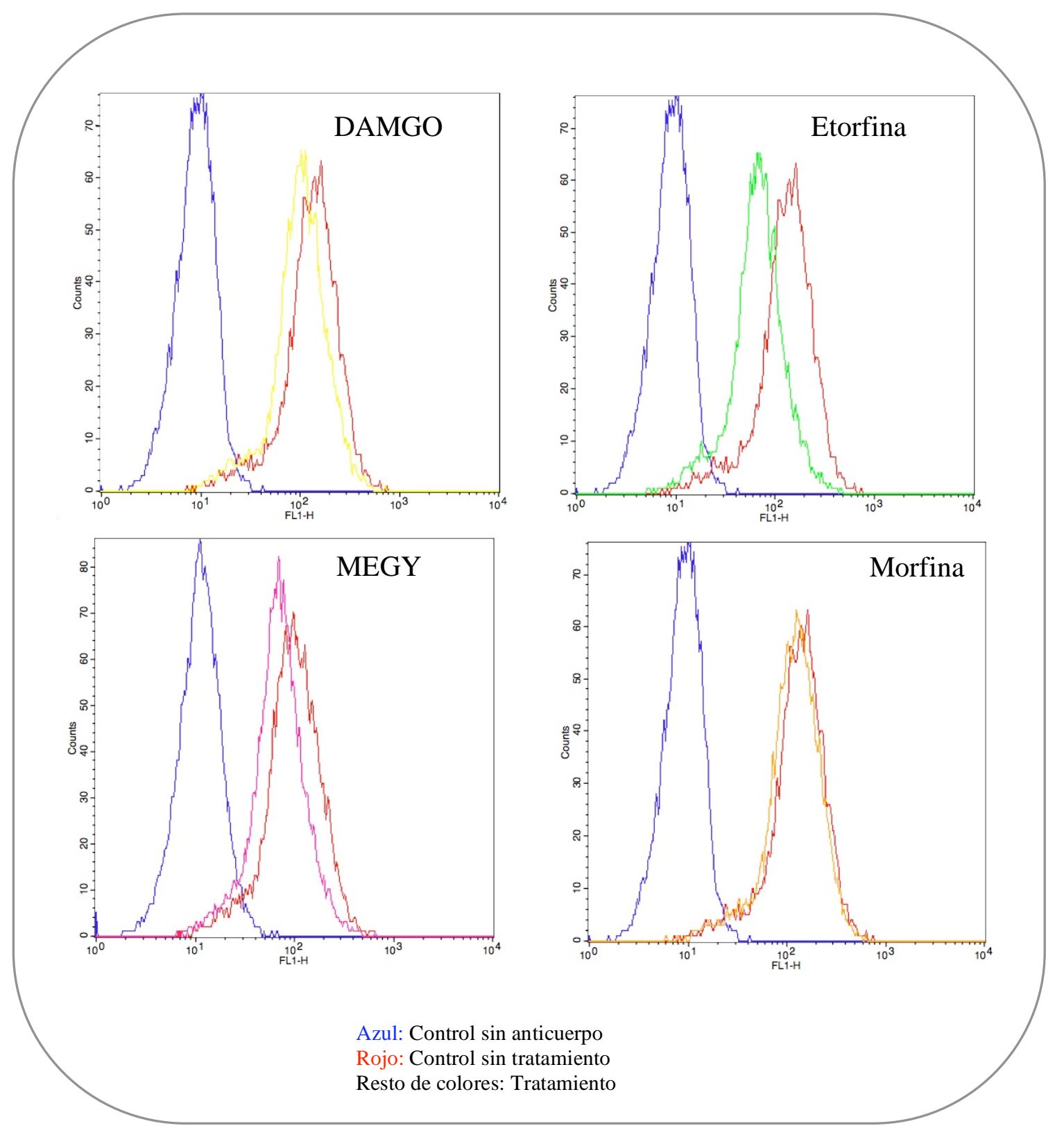

Figura 67: Estudio de internalización por citometría de flujo. En los gráficos se representa el número de células o eventos (Counts) frente a la fluorescencia (FL1-H). La curva azul representa el control sin anticuerpo; este valor no va a dar la posible autofluorescencia de la muestra. La curva roja corresponde con células sin tratamiento; en este caso la mayor parte de los receptores se localizaran en la membrana plasmática. Las curvas del resto de colores representan el tratamiento con la droga lo que provocará un desplazamiento de esta curva con respecto a la control (sin tratamiento) hacia la izquierda, en caso de que se produzca internalización. En el caso de la morfina el desplazamiento es mínimo ya que prácticamente no produce internalización. 
También utilizamos en los experimentos de internalización por citometría el antagonista opioide no selectivo naloxona (30 min. $1 \mu \mathrm{M})$; como cabía esperar el tratamiento con este compuesto no produjo internalización del receptor opioide mu de pez cebra (Figura 68).

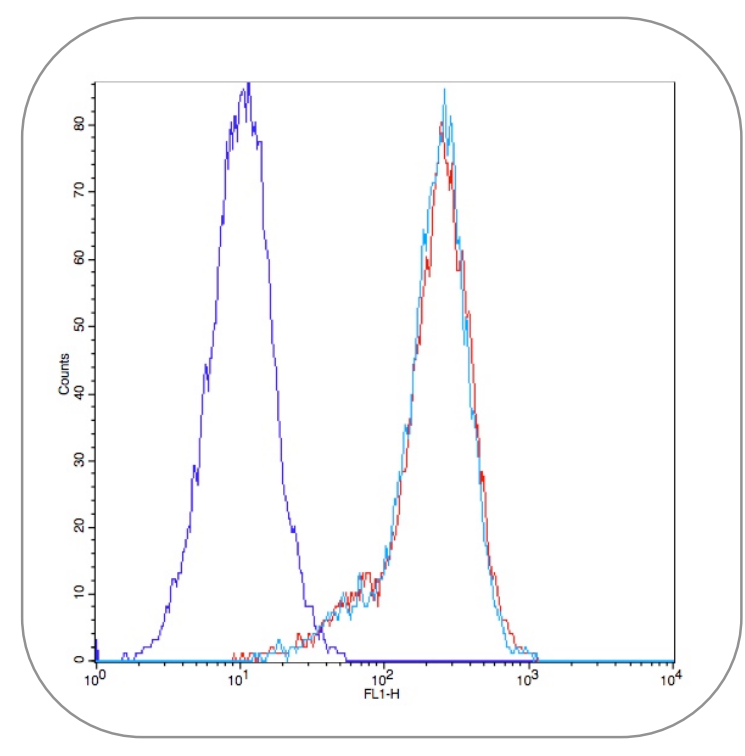

Figura 68: En esta figura se observan las curvas obtenidas por citometría. En los gráficos se representa el número de células o eventos (Counts) frente a la fluorescencia (FL1-H). La curva azul oscuro representa el control sin anticuerpo; este valor no va a dar la posible autofluorescencia de la muestra. La curva roja corresponde con células sin tratamiento; en este caso la mayor parte de los receptores se localizaran en la membrana plasmática. La curva azul celeste representa el tratamiento con naloxona. Se puede apreciar que las gráficas se superponen por lo que no existe internalización. 
Discusión 

En nuestro grupo de investigación se han clonado hasta el momento cinco receptores opioides del pez cebra (Danio rerio) que se han denominado zfDOR1 (ZFOR1), zfMOR (ZFOR2), zfKOR (ZFOR3), zfDOR2 (ZFOR4) y zfORL; (Barrallo y cols., 1998 a y b; Pinal-Seoane y cols., 2006; Barrallo y cols., 2000; Alvar y cols., 2006; Rivas Boyero, Tesis Doctoral, 2003). Estos receptores se corresponden con los receptores opioides delta (zfDOR1 y zfDOR2), mu (zfMOR), kappa (zfKOR) y ORL (zfORL) de mamíferos. Los receptores opioides son los receptores a los que se une la familia de compuestos con mayor capacidad analgésica conocidos, los opiaceos. De entre estos compuestos, los más usados en la clínica como la morfina, metadona, fentanilo o codeína interaccionan de forma selectiva con el receptor de tipo mu (Jaffe y Martin, 1990). Sin embargo, pese a ser los analgésicos más efectivos también inducen efectos secundarios muy graves como la depresión respiratoria y el hecho de que son adictivos. Dada la gran importancia de este tipo de receptor y que tras muchos años de estudio del receptor en distintos modelos de mamífero no se ha llegado a esclarecer su papel en la tolerancia y dependencia a este tipo de compuestos, en este trabajo nos propusimos llevar a cabo el estudio de la funcionalidad del receptor opioide mu de pez cebra, zfMOR.

\subsection{Existencia de duplicados del gen de zfMOR}

Considerando la abundancia de duplicados en el sistema opioide de este organismo (zfDOR1 y zfDOR2, zfPENK, zfPOMC), nos propusimos determinar la existencia de duplicados del receptor opioide mu. Para ello periódicamente se revisaron las bases de datos en busca de secuencias finalizadas. 
Cuando se realizó la comparación de la secuencia de los exones de zfMOR en el base de datos del NCBI (http://www.ncbi.nlm.nih.gov) se obtuvieron distintos resultados en función del exón analizado. En el caso de los exones primero y segundo se produjo una única alineación con el contig NW_001510917; este es uno de los contigs que conforman el cromosoma 13 del pez cebra. Sin embargo cuando comparamos el tercer exón del receptor obtenemos dos posibles alineaciones. La primera, la de mayor homología, se sitúa en el cromosoma 13, al igual que los otros dos exones (Figura 69).

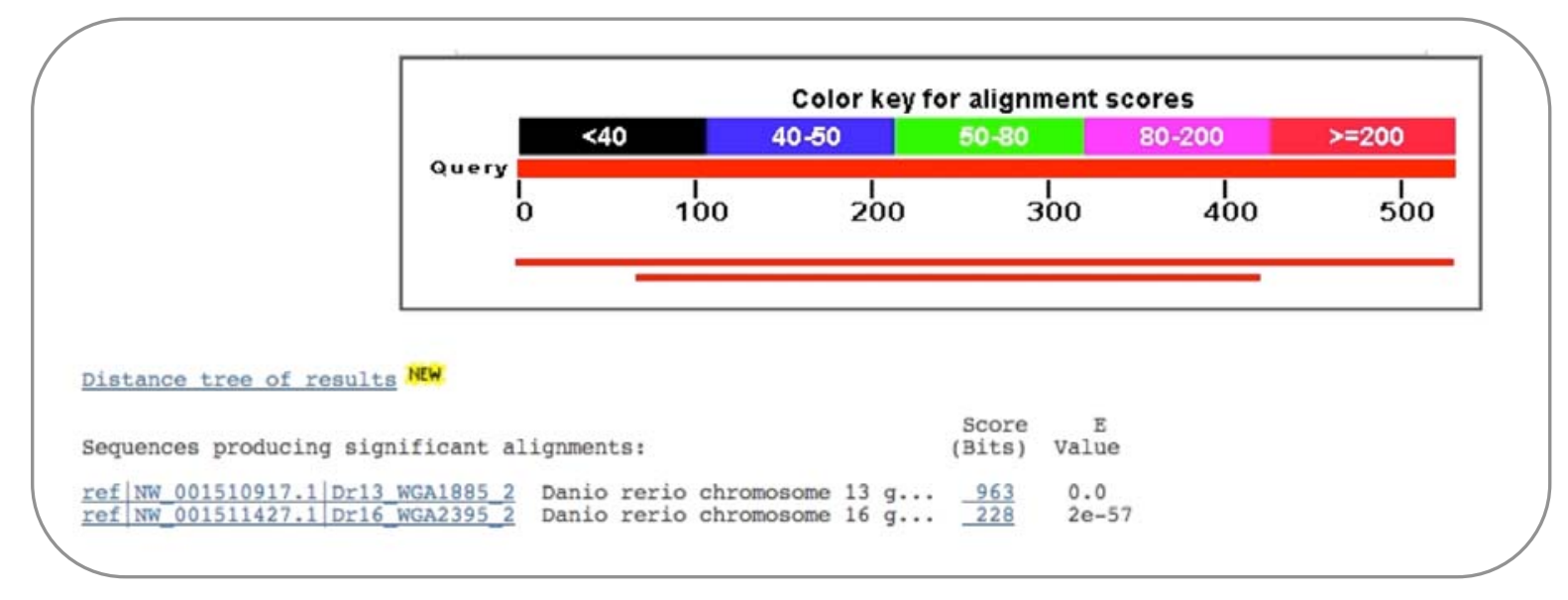

Figura 69: Resultado obtenido al comparar el tercer exón del gen del receptor zfMOR con el genoma del pez cebra. En la parte superior se representa de forma gráfica los dos únicos alineamientos obtenidos. En la parte inferior se observa como uno de los alineamientos se sitúa en el cromosoma 13, correspondiente a zfMOR y el otro en el cromosoma 16.

La segunda secuencia, localizada en el cromosoma 16, presenta una homología del $78 \%$ y por lo tanto podría tratarse de un duplicado de zfMOR. Sin embargo, el estudio posterior de esa secuencia mediante comparación de tipo Blast, con la base de datos, revela que tiene una homología muy alta por un receptor opioide delta de pez cebra (Figura 70). 


\begin{tabular}{|c|c|c|c|c|c|c|c|}
\hline Accession & Description & Max score & Total score & Query coverage & Evalue & Max ident & \\
\hline 001331641.1 & PREDICTED: Danio rerio hypothetical protein LOC792001 & 658 & 658 & $100 \%$ & 0.0 & $100 \%$ & $\mathbf{G}$ \\
\hline 212755.1 & Danio rerio opioid receptor, delta $1 \mathrm{~b}$ (oprd1b), mRNA $>9 \mid$ & 632 & 632 & $100 \%$ & $2 \mathrm{e}-179$ & $98 \%$ & U \\
\hline 1. 131707.1 & Danio rerio opioid receptor, mu 1 (oprm1), mRNA >gb|A| & 233 & 233 & $100 \%$ & $3 e \cdot 59$ & $78 \%$ & UE \\
\hline 1001331385.1 & PREDICTED: Danio rerio hypothetical protein LOC791871 & 217 & 217 & $100 \%$ & $3 e-54$ & $78 \%$ & प्ब \\
\hline
\end{tabular}

Figura 70: Estudio de la secuencia encontrada mediante una comparación de tipo Blast nos demuestra que se trata de una secuencia ya conocida, específicamente se trata de un receptor delta de pez cebra.

Utilizando la base de datos de NCBI llegamos a la conclusión de que la secuencia encontrada no es un duplicado de zfMOR sino que se trata de el receptor delta 2 del pez cebra, zfDOR2 o ZFOR4 (Figura 71).

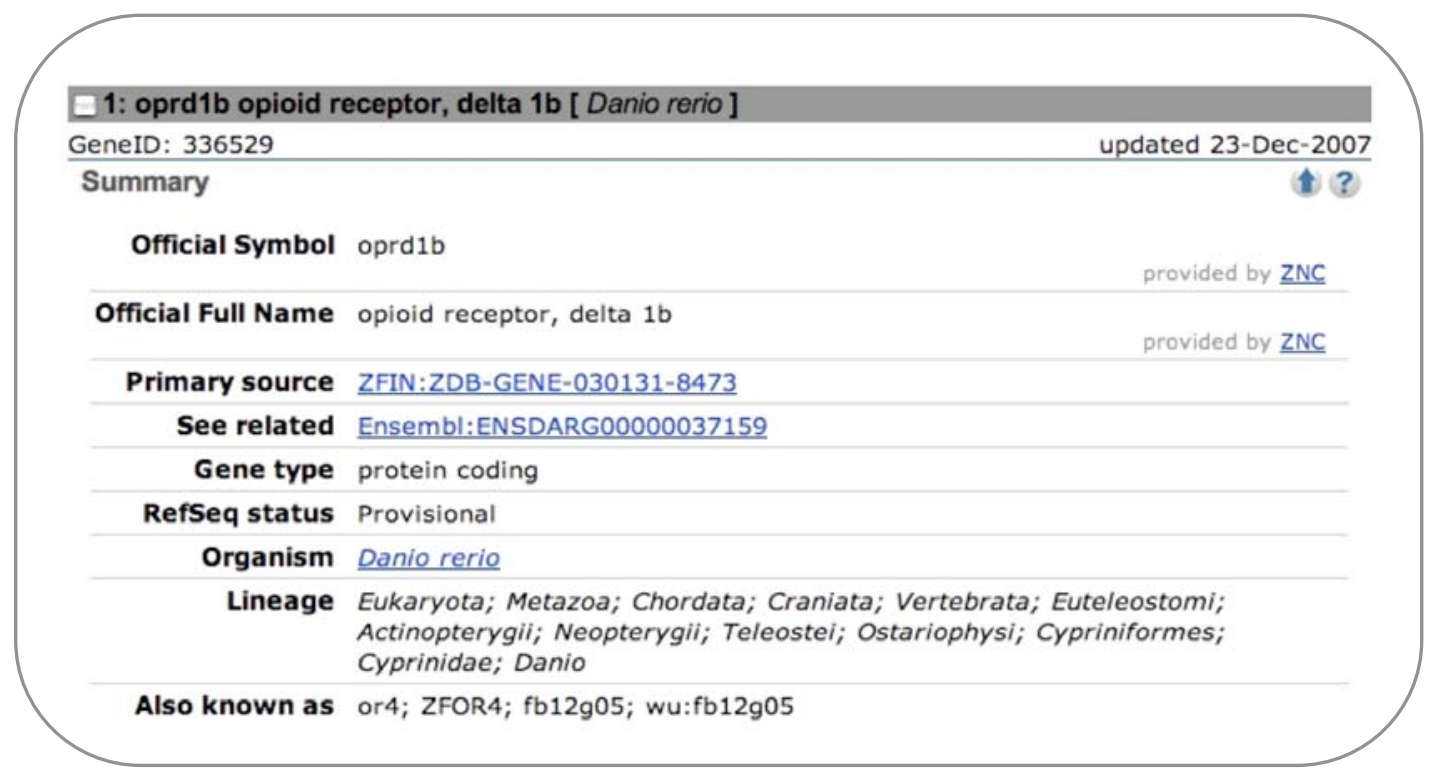

Figura 71: Siguiendo con el estudio de la secuencia del cromosoma 16 podemos ver como se trata de zfDOR2 uno de los receptores de tipo delta del pez cebra.

Como se ha mencionado anteriormente la secuencia del receptor opioide mu de pez cebra se localiza de forma íntegra dentro del contig NW_001510917, situado en el cromosoma 13 (uno de los 25 cromosomas del pez cebra, y formado por 53547397 pares de bases), el hecho de que su secuencia completa se encuentre dentro del mismo contig nos va a permitir determinar la distancia interexónica del receptor zfMOR así como si los sitios de splicing son convencionales o no (Figura 72). 


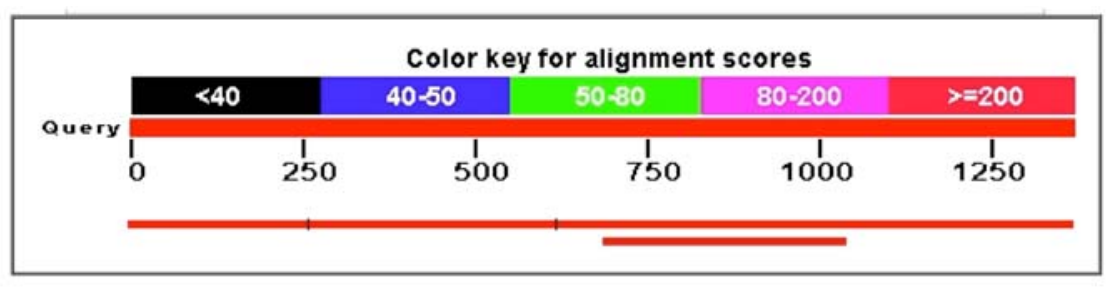

Distance tree of results NEW

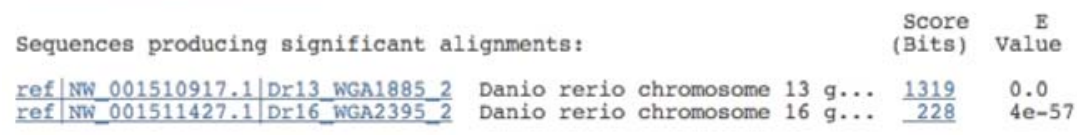

Figura 72: Comparación de los tres exones de forma conjunta nos da un alineamiento con el cromosoma 13 donde podremos encontrar la secuencia completa del gen zfMOR, incluyendo exones, intrones y probablemente regiones promotoras y reguladoras. También encontramos la misma secuencia vista anteriormente en el cromosoma 16.

Realizando la búsqueda utilizando otra base de datos distinta, la página del Instituto Sanger, y utilizando la secuencia del primer exón también obtenemos un alineamiento con una secuencia en el cromosoma 13 (http://www.sanger.ac.uk/) (Figura 73).

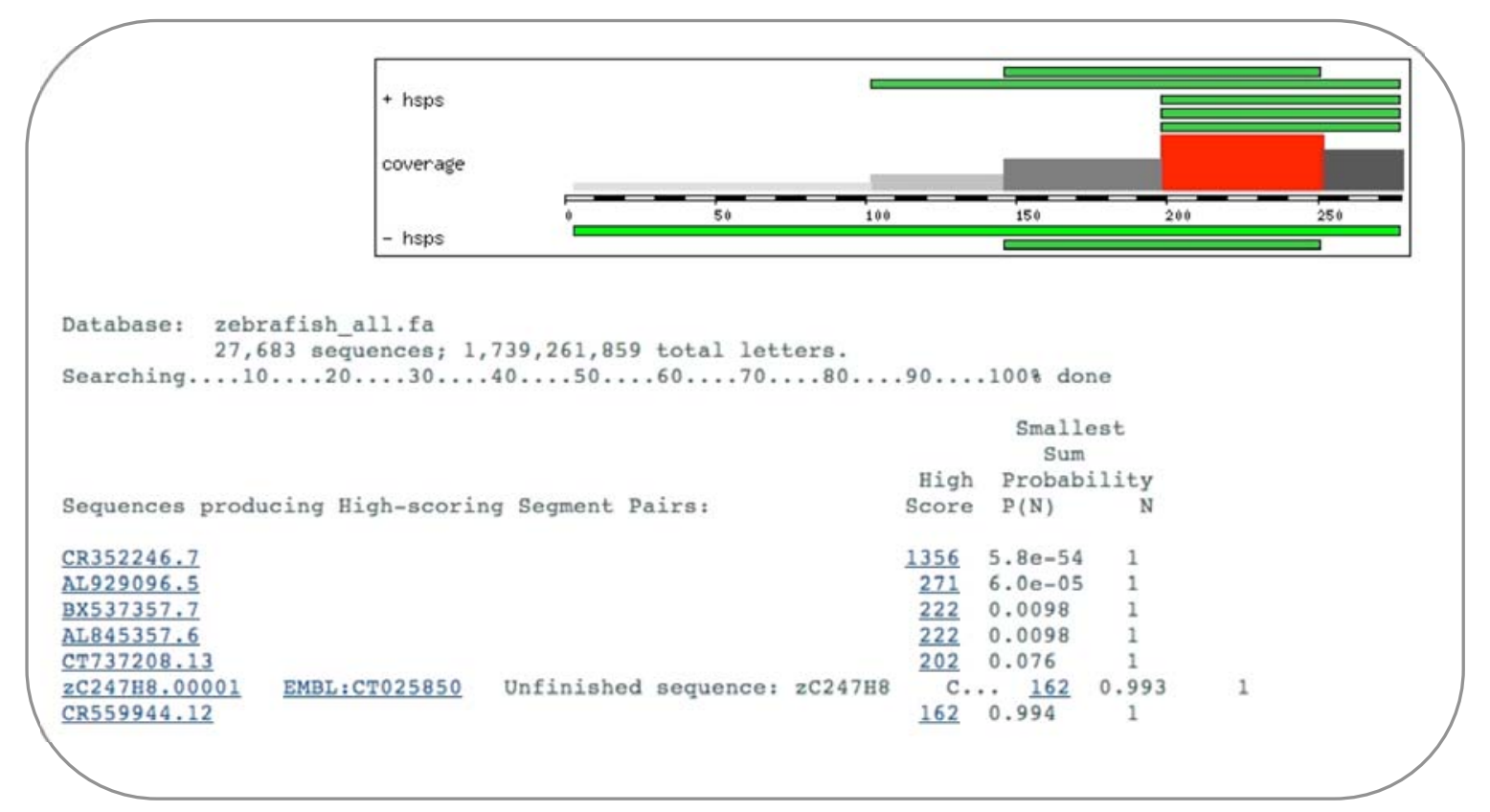

Figura 73: La comparación en la página de Sanger nos muestra un alineamiento con el contig CH211-160H10 que se localiza en el cromosoma 13. Además se pueden ver otras coincidencias pero su valor P es muy elevado para ser consideradas. En verde claro se puede ver la secuencia con mayor homología que corresponde con zfMOR; en verde oscuro secuencias con una menor homología. La zona de color rojo muestra el lugar donde se produce la mayor homología entre todas las secuencias encontradas. 
En este caso la secuencia se localiza dentro del contig $\mathrm{CH} 211-160 \mathrm{H} 10$ que se encuentra en el cromosoma 13 y cuyo nombre de acceso es CR352246. En el caso del segundo alineamiento con mayor homología resultó ser el receptor opioide kappa de pez cebra.

Cuando la comparación es del segundo exón el número de secuencias similares encontradas es mayor (Figura 74).

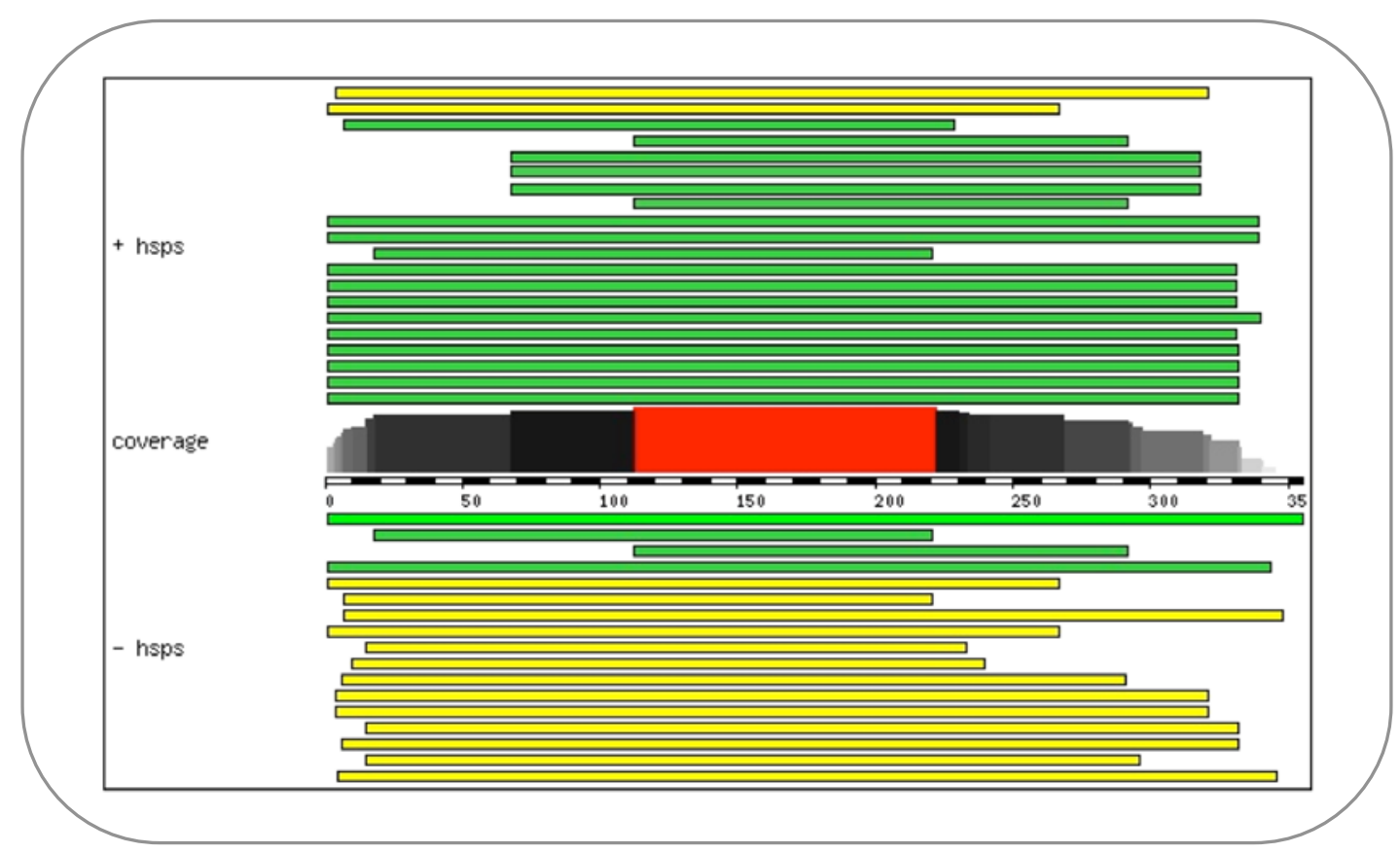

Figura 74: Secuencias similares al segundo exón de zfMOR. Se puede apreciar un gran número de secuencias, sin embargo, ninguna de ellas resultó ser un duplicado de zfMOR. En verde claro se puede ver la secuencia con mayor homología que corresponde con zfMOR; en verde oscuro secuencias con una menor homología y en amarillo aparecen secuencias con menor homología. La zona de color rojo muestra el lugar donde se produce la mayor homología entre todas las secuencias encontradas.

Cuando se llevó a cabo el estudio de la secuencia que presentaba la mayor homología con zfMOR (un $74 \%$ de identidad en una secuencia de 333 pares de bases) esa secuencia resultó ser la misma que la obtenida en la comparación utilizando la base de datos del NCBI, es decir, zfDOR2. Este mismo resultado se 
obtuvo al analizar las siguientes secuencias en orden de homología hasta llegar a una secuencia con un $65 \%$ de homología que resultó ser el receptor delta zfDOR1.

En el caso del tercer exón también hay un alto número de secuencias (Figura 75). Cuando se examinó la secuencia que producía el segundo mejor alineamiento (un $74 \%$ de identidad en una secuencia de 426 pares de bases) se observó que correspondía al receptor opioide ORL del pez cebra, este mismo resultado se obtuvo con las siguientes secuencias hasta llegar a una con un $68 \%$ de homología que correspondió de nuevo con zfDOR1.

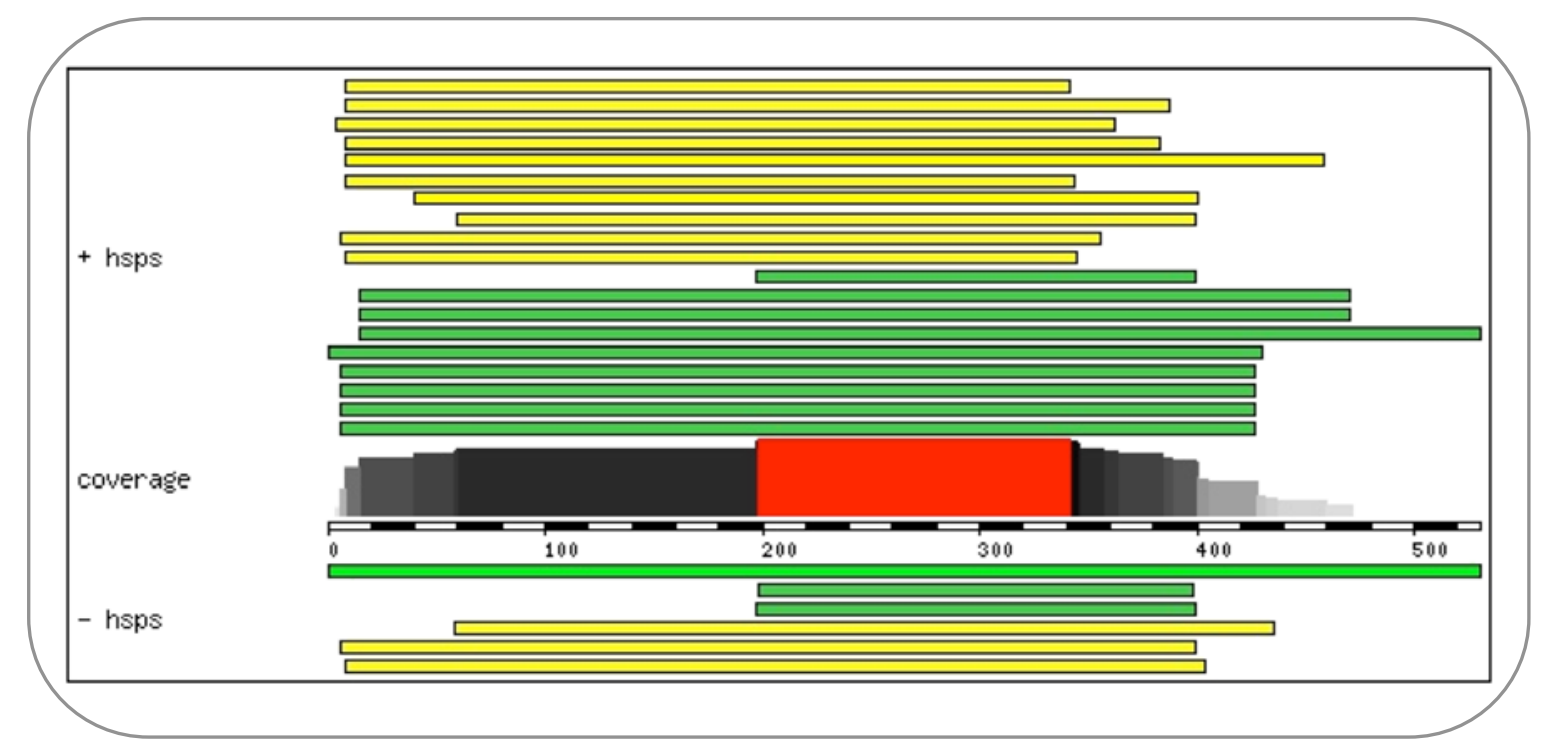

Figura 75: Secuencias similares al tercer exón de zfMOR. El estudio posterior de los alineamientos producidos determinó que ninguno de ellos se trataba de un duplicado de zfMOR. En verde claro se puede ver la secuencia con mayor homología que corresponde con zfMOR; en verde oscuro secuencias con una menor homología y en amarillo aparecen secuencias con menor homología. La zona de color rojo muestra el lugar donde se produce la mayor homología entre todas las secuencias encontradas.

Si el estudio lo realizamos en la página del ENSEMBL podemos observar como la comparación de los 3 exones nos produce un alineamiento con una secuencia en el cromosoma 13, al igual que en los casos anteriores (Figura 76). 


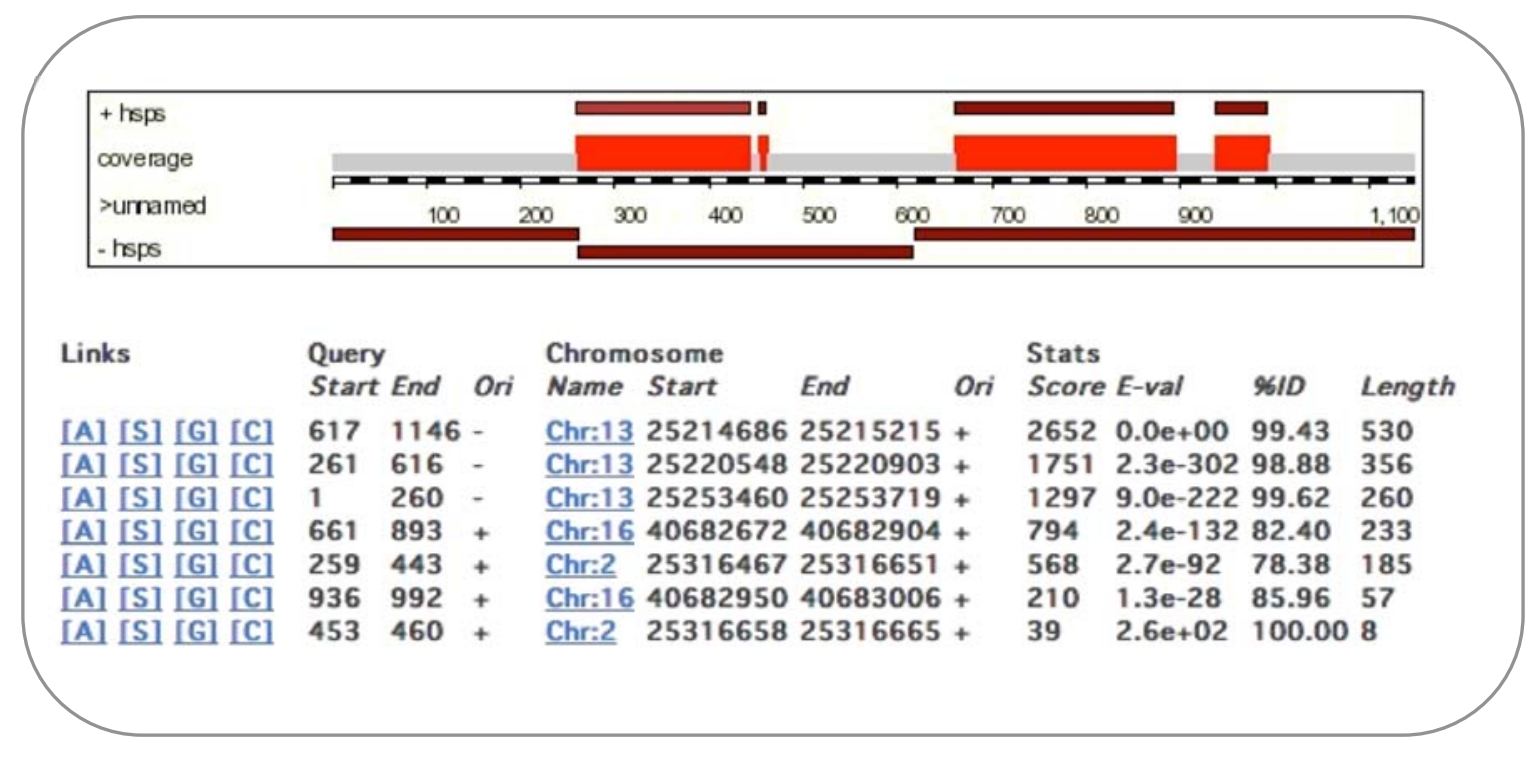

Figura 76: En la parte superior de la figura se puede observar el alineamiento producido en la base de datos de Ensembl de los tres exones de zfMOR con el genoma secuenciado de pez cebra. En la parte inferior podemos ver como los tres exones se alinean dentro del cromosoma 13 y vemos alineamientos en el cromosoma 16 y cromosoma 2 que se corresponden con los receptores zfDOR2 y zfORL.

También podemos observar una similitud con una secuencia del cromosoma 16 que al igual que en los casos anteriores se trata de zfDOR2. Una secuencia más aparece en este caso, presente en el cromosoma 2, y que resultó ser el receptor de tipo kappa, zfKOR.

Puesto que al comparar la secuencia de zfMOR, tanto por exones como de forma completa, no encontramos ninguna secuencia con una alta homología no descrita, sino que las secuencias encontradas se corresponden con otros receptores opioides del pez cebra podemos concluir que, en estos momentos no hay evidencias de la existencia de un duplicado del receptor opioide mu de pez cebra, zfMOR, sin embargo, no podemos descartar su existencia completamente ya que aun hay un $24 \%$ del genoma del pez cebra por secuenciar. 


\subsection{Comparación de zfiMOR con otros receptores opioides}

Al comparar la secuencia aminoacídica de zfMOR frente a la secuencia de los demás receptores opioides caracterizados en el pez cebra y con los receptores opioides presentes en ratón, rata y humano, los más estudiados, podemos observar como zfMOR se separa, junto con los receptores opioides de tipo mu presentes en mamíferos, en una misma rama (Figura 77). Esto también ocurre en el caso del resto de los receptores. En esa misma rama en la que se encuentran los receptores de tipo mu podemos observar como los de rata y ratón se encuentran muy próximos entre sí y también próximos al humano y sin embargo en el caso del receptor de pez cebra la distancia es mayor. Este hecho refleja las diferencias entre estos receptores que está relacionada con la distancia filogenética entre las distintas especies.

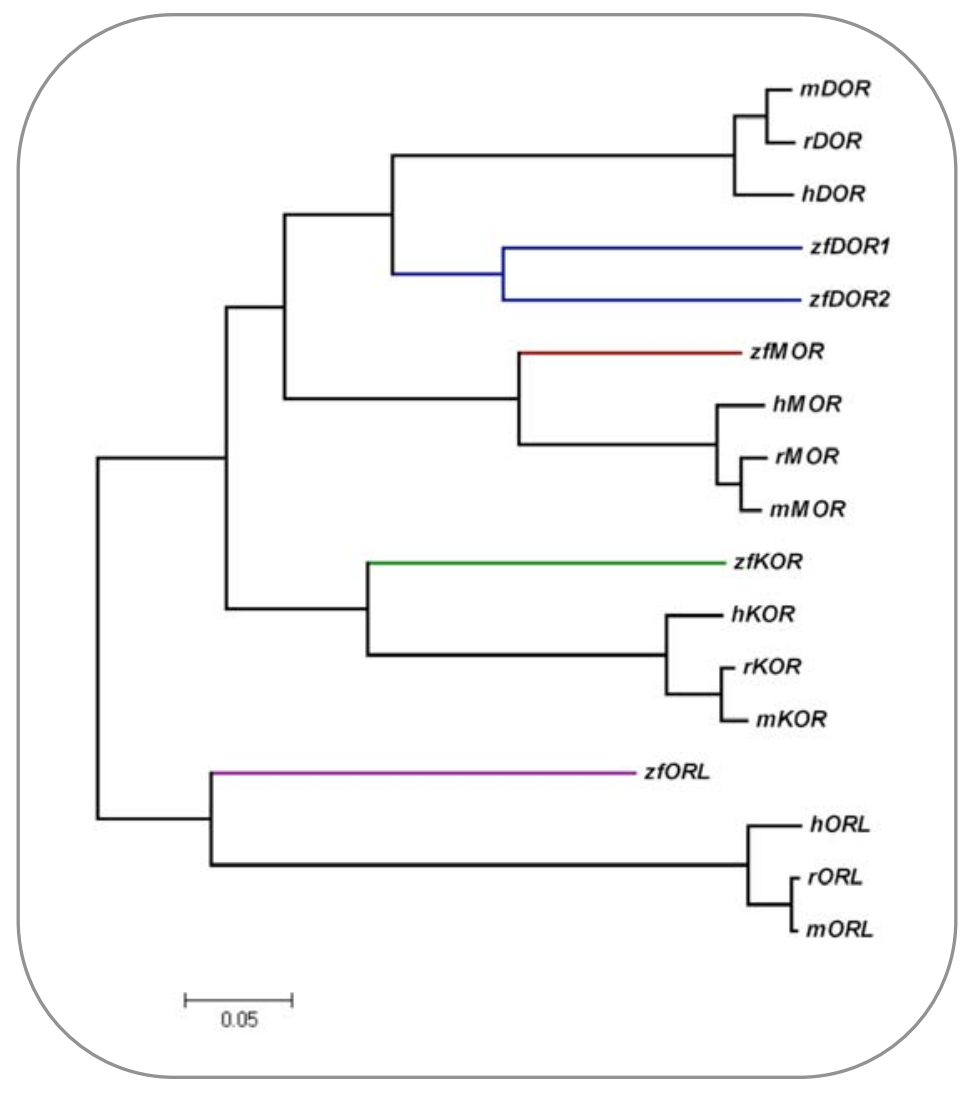

Figura 77: Filograma generado mediante el método de "neighborjoining" a partir del alineamiento de las secuencias proteicas de los receptores opioides de pez cebra, humano, ratón y rata. La escala en la parte inferior del filograma representa la distancia de las ramas. 
Estas diferencias se pueden cuantificar. En la tabla 10, realizada utilizando los valores de homología tras realizar la comparación de tipo ClustalW, se pueden apreciar los valores de homología entre las secuencias peptídicas de los distintos receptores en porcentaje.

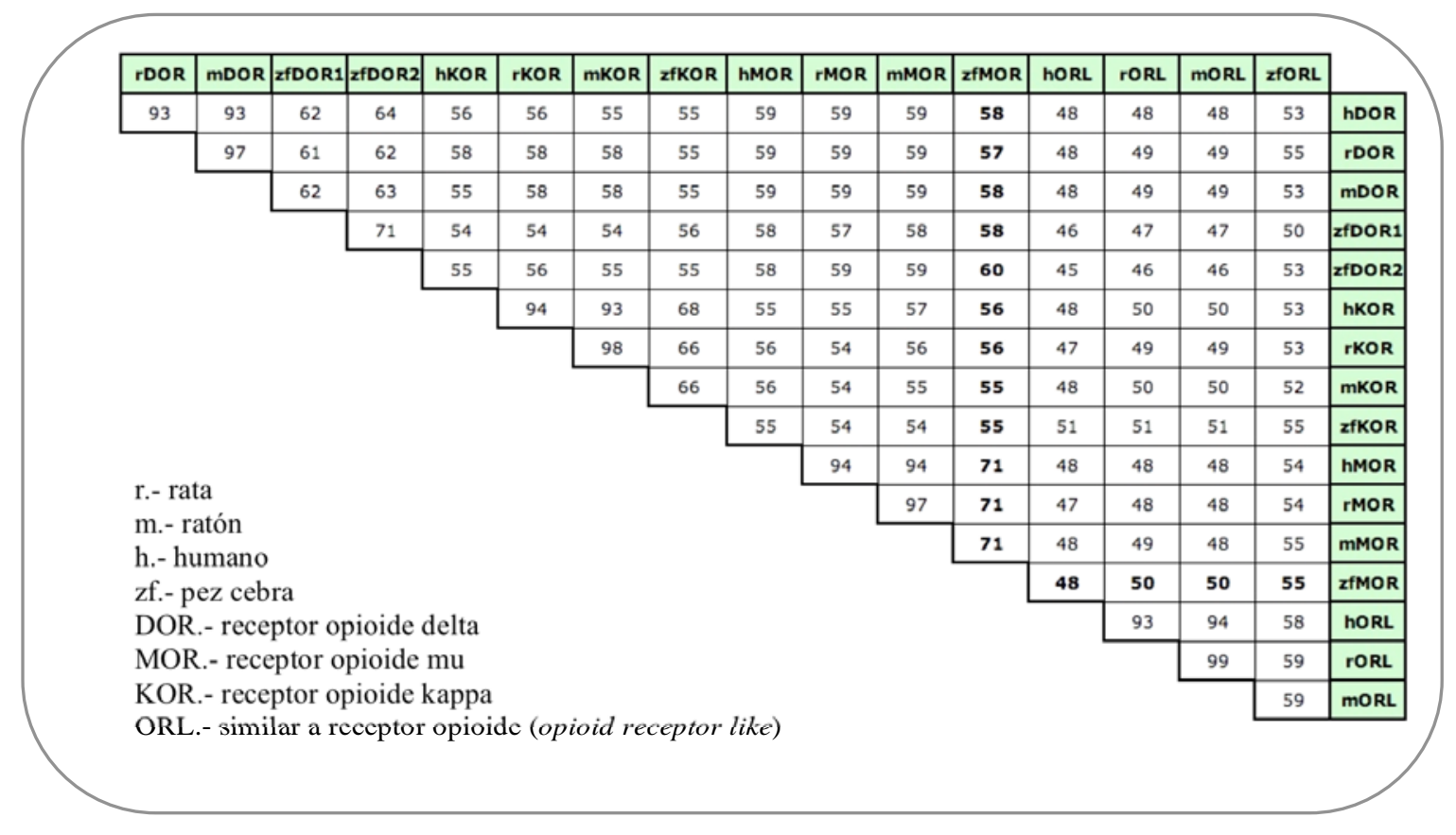

Tabla 10: Valores de homología entre los distintos receptores opioides. Esta tabla se ha obtenido recogiendo los valores de homología tras la comparación de tipo ClustalW de las secuencias peptídicas de los receptores opioides.

La homología media entre el receptor de pez cebra y los receptores de mamíferos es del $71 \%$ mientras que en el caso de los receptores delta es del $58 \%$ y de los kappa del $56 \%$. La homología frente a los receptores de tipo ORL es alrededor de $50 \%$. Esta comparación nos permite afirmar que al menos desde el punto de vista de su secuencia el receptor zfMOR efectivamente parece ser un receptor opioide de tipo mu. 
Se puede llevar a cabo una comparación algo más detallada si utilizamos las secuencias de receptores opioides de tipo mu que se han clonado en distintos organismos, además de los clásicos como ratón rata y humano (Figura 78). De esta forma podemos observar como el receptor de pez cebra se separa conjuntamente con el de Catostomus commersoni; a su vez los receptores de Rana pipiens y Taricha granulosa, dos anfibios, se separan también en una misma rama. Por último todos los mamíferos se separan también en una única rama. Al igual que en el caso anterior la distancia de cada una de las ramas del árbol refleja la similitud entre los receptores opioides de distintas especies; así por ejemplo la homología entre el receptor mu de humano y de chimpancé es del $99 \%$, mientras que entre el pez cebra y Catostomus commersoni la homología es del $87 \%$.

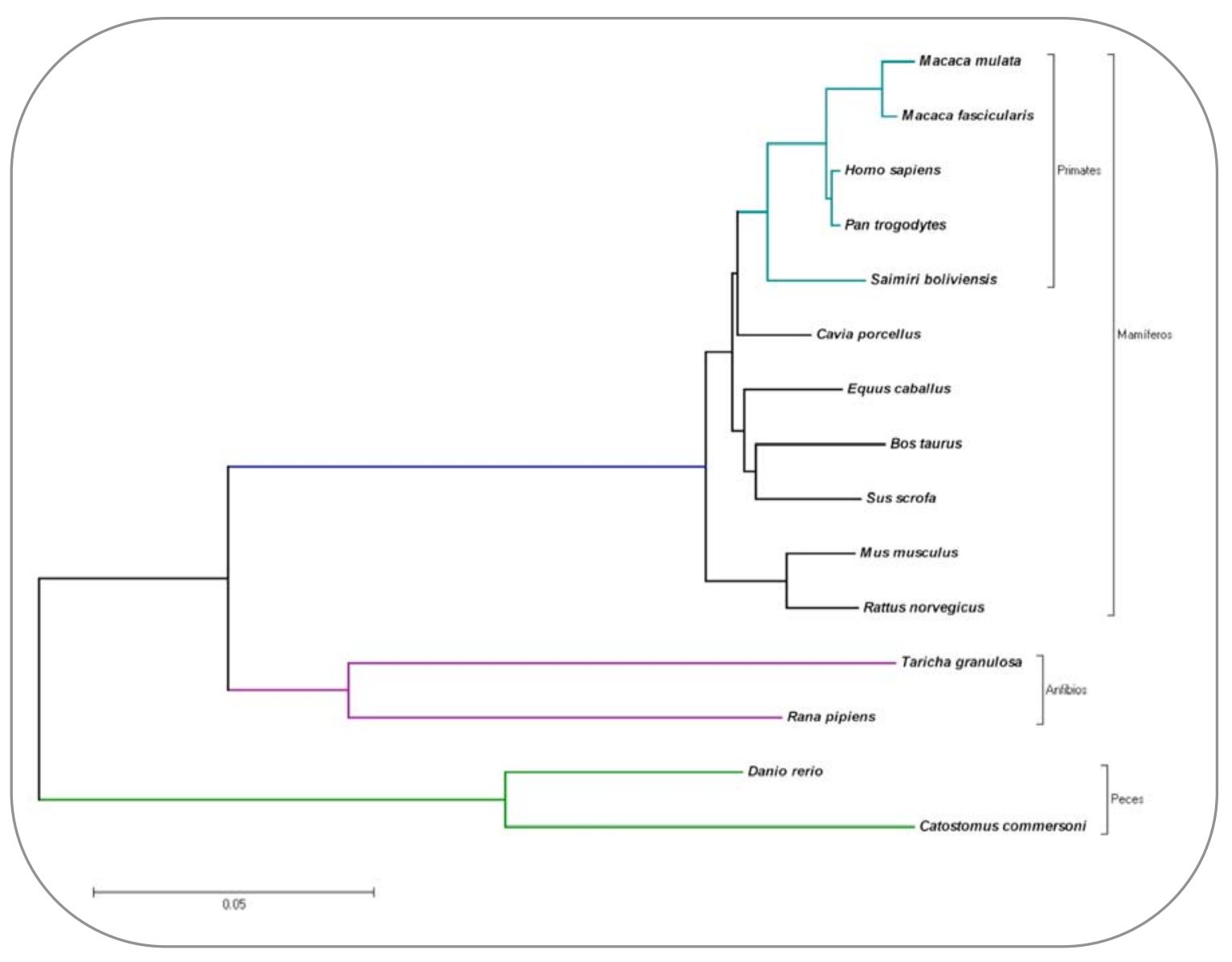

Figura 78: Filograma generado mediante el método de "neighbor-joining" a partir del alineamiento de las secuencias proteicas de los receptores opioides de tipo mu de distintas especies. La escala en la parte inferior del filograma representa la distancia de las ramas. Para realizar el filograma se ha utilizado el programa MEGA4. 
También podemos realizar el estudio de la homología por regiones entre distintos receptores (Tabla 11); de esta manera podemos determinar cuáles son las zonas más conservadas y que por tanto desarrollan un papel fundamental en el funcionamiento de los receptores.

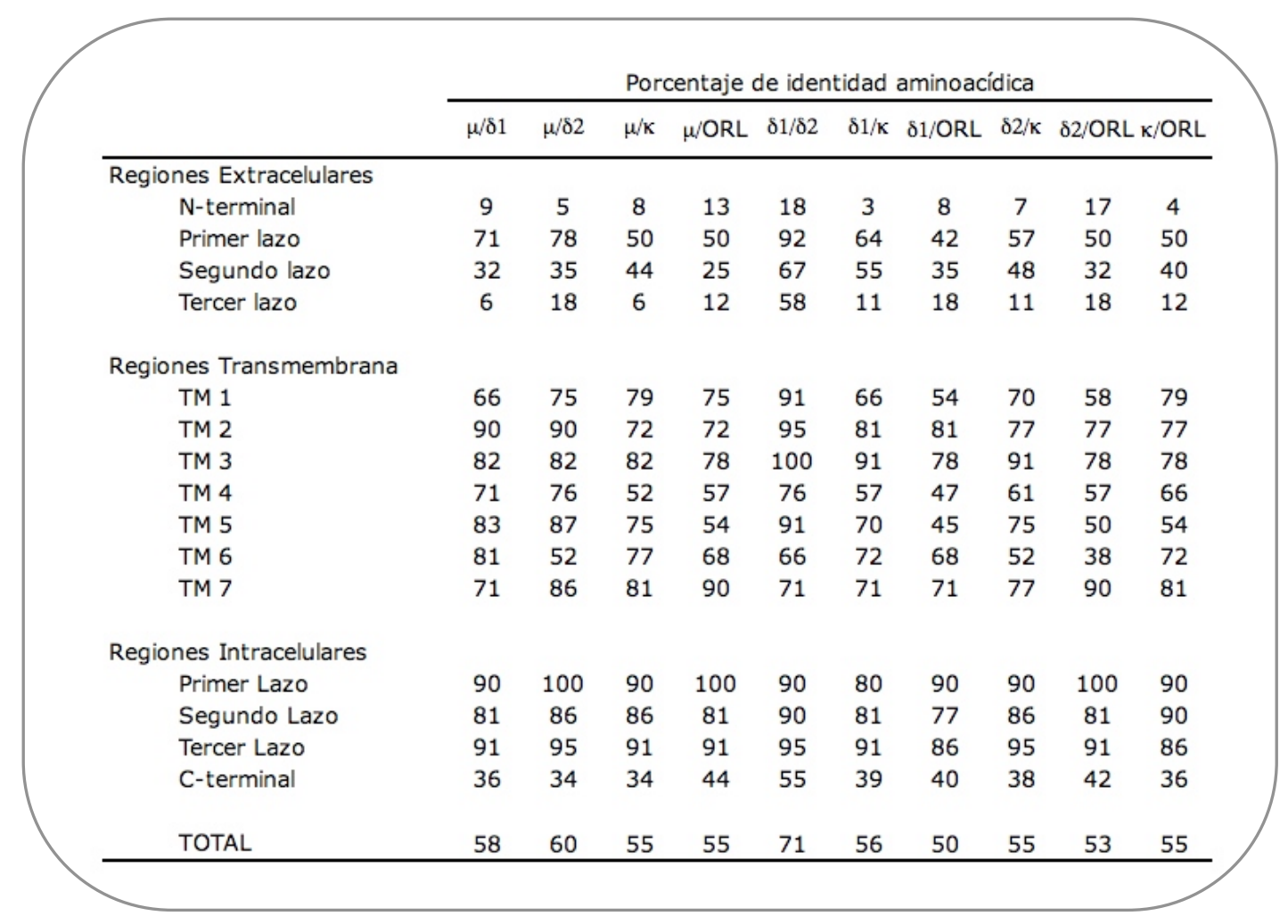

Tabla 11: Homología entre receptores opioides por las distintas regiones que lo forman; extremos amino y carboxilo terminal, lazos intra y extra celulares y dominios transmembrana. La comparación se ha llevado a cabo mediante comparación de tipo ClustalW.

Como se puede observar en la tabla la mayor homología se encuentra en los dominios transmembrana, al igual que ocurre en los receptores de otras especies (Wang y cols., 1993) y en los lazos intracelulares. Por el contrario, las regiones que presentan la menor homología son los lazos extracelulares y los extremos amino y carboxilo terminal. La región que presenta la menor homología entre los receptores de 
pez cebra, al igual que pasa entre mamíferos es la región amino terminal (Kaufman y cols., 1995).

\subsection{Unión de ligandos opioides al receptor}

El primer paso para el estudio de la actividad del receptor zfMOR es saber si este es capaz de unir ligandos opioides. El estudio de la unión de un ligando a una macromolécula se puede llevar a cabo de diversas maneras, utilizando propiedades físico químicas que se modifican en el ligando o en la macromolécula cuando se produce la unión, por ejemplo. En nuestro caso hemos optado por el método más utilizado para el estudio de los receptores opioides. Utilizamos un compuesto marcado de forma radiactiva el cual podremos detectar si está unido o no al receptor. En este trabajo como queremos realizar el estudio del receptor zfMOR de forma aislada, es decir, sin ningún tipo de influencia por parte de otros receptores opioides, debemos establecer un sistema de expresión que nos permita este objetivo. Para ello hemos transfectado de forma estable el receptor opioide mu de pez cebra en la línea celular HEK-293, que no expresa de forma natural receptores opioides (Arden y cols., 1995; Segredo y cols., 1997), de forma que se pueda expresar y estudiarlo sin influencia por parte de otros receptores opioides (Figura 33).

El primer resultado que obtuvimos referente a la funcionalidad del receptor fue que las células HEK-293 transfectadas con el plásmido pcDNA3.1 que además contenía la ORF del gen zfMOR eran capaces de unir el antagonista no selectivo ${ }^{3} \mathrm{H}-$ diprenorfina y además esa unión es desplazada por el también antagonista no selectivo 
naloxona. Este hecho es la primera confirmación de tipo funcional de que el receptor zfMOR es un receptor de tipo opioide.

\subsubsection{Estudios de saturación usando ${ }^{3}$ H-Diprenorfina}

Tras llevar a cabo un experimento de saturación utilizando diprenorfina tritiada obtuvimos un valor de afinidad, expresado como $K_{d}$ o constante de disociación, de $0.52 \mathrm{nM}$. Este valor es muy similar al encontrado en otras especies de mamíferos, como en el caso del receptor de rata en el cual el valor de $K_{d}$ es de 0.38nM (Chen y cols., 1993) o el de vaca de $0.12 \mathrm{nM}$ (Onoprishvivili y cols., 1999) y difiere un poco más aunque está dentro del mismo orden del de ratón $2.3 \mathrm{~nm}$ (Kaufman y cols., 1995), aunque otros autores han obtenido un valor de $0.61 \mathrm{nM}$ para ese mismo organismo (Blake y cols., 1997). En la bibliografía los valores obtenidos de población receptorial o $\mathrm{B}_{\max }$ son muy variables, al tratarse de sistemas de expresión en los que en función del promotor utilizado, el tipo celular elegido, el método de transfección escogido, así como la pureza y cantidad de DNA pueden producir variaciones en los niveles de expresión muy grandes. De forma general en la bibliografía revisada se obtienen niveles de expresión desde varios femtomoles a picomoles por miligramo de proteína utilizada. Los niveles obtenidos de expresión del receptor opioide mu de pez cebra en este estudio son comparables a los niveles de las células que expresan el receptor en varias regiones del sistema nervioso, como Locus coeruleus, núcleo parabraquial, sustancia gris periacueductal, tálamo; en general, aquellas áreas involucradas en la modulación sensorial y nociceptiva (Thompson y cols., 1993; Kaufman y cols., 1995; Gharagozlov y cols., 2003). 
Ante el resultado positivo de la unión específica y saturable de la diprenorfina al receptor zfMOR, y puesto que molecularmente este receptor es un receptor de tipo $\mathrm{mu}$, decidimos realizar un experimento de saturación utilizando un compuesto mu selectivo. El compuesto elegido fue ${ }^{3} \mathrm{H}-\mathrm{DAMGO}$ un agonista peptídico con alta afinidad por los receptores de tipo mu de mamífero. Obtuvimos una unión específica y saturable con un valor de afinidad $\left(\mathrm{K}_{\mathrm{d}}\right)$ de $3.05 \mathrm{nM}$. En este caso el valor obtenido es un poco mayor que el descrito para otros receptores opioides tipo mu, sin embargo se mantiene en el rango nanomolar. En el caso del receptor mu humano el valor de $\mathrm{K}_{\mathrm{d}}$ descrito es de $1.2 \mathrm{nM}$ (Wang y cols., 1994a) mientras que en el de rata el valor es de $0.4 \mathrm{nM}$ (Wang y cols., 1993), sin embargo otros autores muestran valores de $1.2 \mathrm{nM}$ (Thompson y cols., 1993) para el caso de este mismo organismo. El receptor mu bovino presenta una $\mathrm{K}_{\mathrm{d}}$ frente a DAMGO de $1.2 \mathrm{nM}$ (Onoprishvili y cols., 1999). Por último, en el receptor mu de ratón se obtiene un valor de $0.57 \mathrm{nM}$ (Raynor y cols., 1994). Se puede observar por tanto que los valores obtenidos para el receptor de pez cebra se encuentran dentro del mismo rango que en el grupo de mamíferos estudiados.

Los resultados descritos previamente junto con la bibliografía utilizada hacen referencia a un sitio de unión para el compuesto DAMGO. Sin embargo, los resultados obtenidos para el receptor de pez cebra también se pueden ajustar a dos sitios de unión. Este hecho se puede ver gráficamente en la curva de saturación, sin embargo es más sencillo de visualizar utilizando la transformación de Rosenthal de los datos (Figura 35). Cuando la curva se ajusta a un sitio de unión, la transformación de Rosenthal debe dar una línea recta con pendiente negativa, sin embargo en nuestro 
caso la transformación de Rosenthal se ajusta mejor a una línea curva. En el caso del análisis de dos sitios de unión los valores de afinidad obtenidos, medidos como $\mathrm{K}_{\mathrm{d}}$ fueron de $\mathrm{K}_{\mathrm{d} 1}=0.28 \mathrm{nM}$ y $\mathrm{K}_{\mathrm{d} 2}=6.12 \mathrm{nM}$ (Figura 36). Estos resultados se ajustan bastante bien a lo descrito por Darlison (Darlison y cols., 1997) que observa unos valores de $\mathrm{K}_{\mathrm{d} 1}=0.63 \mathrm{nM}$ y $\mathrm{K}_{\mathrm{d} 2}=3.8 \mathrm{nM}$ en el caso del receptor opioide mu de Catostomus commersoni. También en el caso del receptor de rata (Wang y cols., 1993) se aprecia una transformación de Rosenthal que apunta a dos sitios de unión pese a que los autores lo definen como un sitio. Dado que no es común encontrar bibliografía en la que se haga referencia a dos sitios de unión cuando se hacen saturaciones utilizando DAMGO tritiado también llevamos a cabo el mismo experimento utilizando membranas purificadas de células en cultivo que expresaban el receptor opioide mu de rata (Figura 38). Los resultados obtenidos apuntan claramente hacia dos sitios de unión con unos valores de $\mathrm{K}_{\mathrm{d}}$ de $\mathrm{K}_{\mathrm{d} 1}=0.6 \mathrm{nM}$ y $\mathrm{K}_{\mathrm{d} 2}=16.9 \mathrm{nM}$. Además también se utilizó como control la saturación utilizando diprenorfina tritiada corroborando la existencia de un único sitio de unión, tal y como corresponde a un antagonista (Arden y cols., 1995) (Figura 37).

El hecho de que se obtengan dos sitios de unión no puede ser explicado de igual forma que cuando se obtienen dos sitios de unión utilizando, por ejemplo, membranas de cerebro purificadas. En ese caso la presencia de varios receptores opioides, ya sean tipos distintos (delta, mu y kappa) o subtipos $\left(\mathrm{mu}_{1}, \mathrm{mu}_{2}\right)$ explicaría la existencia de sitios de unión con distintas afinidades. Sin embargo en nuestro caso hemos demostrado que las células HEK-293 no son capaces de unir ligandos opioides, al igual que aparece en la bibliografía (Arden y cols., 1995; Segredo y cols., 1997), por tanto la unión de estos sólo se producirá cuando las células estén expresando el 
receptor transfectado. Esto descartaría la posibilidad de distintos tipos de receptores con distintas afinidades. En el caso de los subtipos o las isoformas, parece que estas se expresan en determinados momentos o regiones del sistema nervioso principalmente, luego debe haber una regulación que dicte cuándo y dónde se han de expresar (Abbadie y cols., 2000; Abbadie y cols., 2004; Oldfield y cols., 2008). Por tanto no parece que sea probable que en células HEK-293 se encuentre la maquinaria necesaria para producir esa regulación permitiendo la expresión de varias isoformas, por ejemplo mediante procesamiento alternativo del mensajero. Una explicación que parece más apropiada a esta situación sería que ${ }^{3} \mathrm{H}$-DAMGO es capaz de distinguir entre dos tipos de receptores, pero la ${ }^{3} \mathrm{H}$-diprenorfina no es capaz de llevar a cabo dicha distinción. Puesto que la diprenorfina es un antagonista, es decir, que no provoca ninguna respuesta intracelular tras su unión al receptor, este no va a diferenciar entre los receptores que se encuentren acoplados a proteínas $\mathrm{G}$ de aquellos que no lo estén. Sin embargo DAMGO es un agonista y como tal provocará una respuesta intracelular, siempre que, los receptores a los que se una se encuentren correctamente acoplados a las proteínas efectoras. De esta forma DAMGO tiene una mayor afinidad por los receptores acoplados frente a los desacoplados, lo que puede determinar la presencia de dos sitios de unión al ligando cuando se lleva a cabo un experimento de saturación con un agonista (Dolhman y cols., 1991; Zastawny y cols., 1994; Darlison y cols., 1997; Onoprishvili y cols., 1999) El hecho de que en la bibliografía no suelan aparecer esos dos sitios de unión puede tener varias explicaciones como son que la concentración de ligando tritiado utilizado no permita la determinación de uno de los dos sitios, el de baja o el de alta afinidad; también, diferencias en las concentraciones de GDT/GTP en la reacción, el método de purificación de las membranas, etc. pueden modificar los estados de acoplamiento del 
receptor y las proteínas $\mathrm{G}$ modificándose, por tanto, la capacidad de unión del ligando.

En el caso de la saturación con DAMGO también llama la atención nuestro resultado en relación a la población receptorial. Como se mencionó anteriormente este parámetro, como tal, no aporta mucha información en el caso de las células transfectadas, sin embargo la comparación entre la $\mathrm{B}_{\max }$ obtenida cuando se utiliza diprenorfina y DAMGO es interesante. En el caso de la diprenorfina el valor obtenido es de $3629 \mathrm{fmol} / \mathrm{mg}$ de proteína mientras que en el caso de DAMGO es de 1717 fmol/mg de proteína (Figuras 35 y 36, respectivamente). Esta diferencia en $B_{\max }$ entre los dos compuestos puede ser explicada en los mismos términos que el caso anterior, lo cual ha sido descrito previamente por Onoprishvili (Onoprishvili y cols., 1999) para el receptor mu de bovino. Este grupo obtiene una reducción de población receptorial cercana al $70 \%$ y lo atribuyen a que solo el $30 \%$ de los receptores se encuentran acoplados a proteínas $\mathrm{G}$ y los que no están acoplados presentan una afinidad tan baja por el ligando que ésta no se puede detectar con la concentración de radioligando utilizada. Pese a que esta explicación se ajuste a los resultados y tal y como los propios autores apuntan, los valores de acoplamiento son mucho más bajos de los que se suelen obtener. Similares resultados se obtienen utilizando los compuestos DAMGO y bremazocina tritiados, aunque estos autores no proponen ninguna explicación (Seki y cols., 1998b). Otra explicación posible podría ser la siguiente. Las membranas purificadas a partir de células que expresan el receptor opioide no van a estar en forma lineal en la solución acuosa, sino que se organizan en forma de vesículas presentado una mayor estabilidad. Cuando esas vesículas se forman tras la ruptura de las membranas celulares en el proceso de purificación, el receptor opioide 
puede quedar con el sitio de unión del ligando hacia el exterior de la vesícula o hacia el interior (Figura 79).

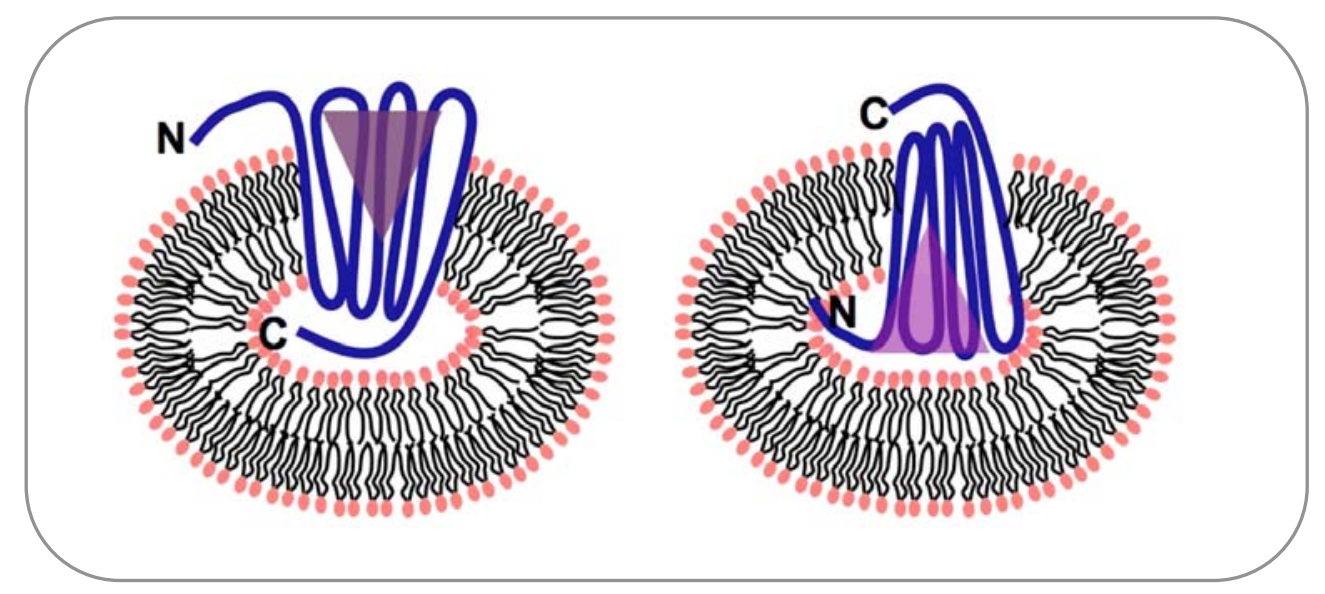

Figura 79: Representación de vesículas de membrana con un receptor opioide. En la figura de la izquierda podemos ver un receptor que tiene expuesto hacia el exterior el sitio de unión para el ligando y por tanto será accesible tanto para sustancias lipofílicas como hidrofílicas. La imagen de la derecha muestra un receptor con el sitio de unión hacia el interior de la vesícula, por tanto solo será accesible para aquellas moléculas capaces de atravesar la bicapa lipídica.

Cuando utilizamos un compuesto como la diprenorfina tritiada, ésta puede atravesar las membranas celulares y por tanto se unirá a todos los receptores presentes en la muestra; por otro lado, cuando el ligando utilizado es ${ }^{3} \mathrm{H}-\mathrm{DAMGO}$ que, al ser un péptido polar, no puede atravesar las membranas o lo hará de forma muy lenta por lo que solamente se podrá unir a los receptores que tengan sus sitios de unión hacia la solución acuosa (Arden y cols., 1995; Capeyrou y cols., 1997). Suponiendo el proceso de formación de las vesículas al azar, un $50 \%$ de los receptores tendrán su sitio de unión hacia fuera y el otro 50 \% hacia el interior de la vesícula, ajustándose el modelo a los resultados obtenidos.

Este mismo resultado se obtuvo también cuando realizamos el estudio con el receptor de rata con unos valores de $B_{\max }$ de 3440 fmol/mg de proteína para la 
diprenorfina tritiada y de $1906 \mathrm{fmol} / \mathrm{mg}$ de proteína en el caso de DAMGO tritiado (Figuras 37 y 38, respectivamente). Otro resultado similar a lo encontrado para el receptor opioide mu de pez cebra, aunque utilizando un radioligando distinto se encontró en el receptor del teleósteo Catostomus commersoni. En este caso se utilizaron la naloxona y DAMGO marcados de forma radiactiva. Para la naloxona el valor de $\mathrm{B}_{\max }$ obtenido fue de $11.7 \mathrm{pmol} / \mathrm{mg}$ de proteína mientras que para DAMGO el valor se redujo hasta $3.5 \mathrm{pmol} / \mathrm{mg}$ de proteína (Darlison y cols., 1997).

\subsubsection{Estudios de saturación utilizando otros ligandos opioides}

Para continuar con la caracterización del receptor zfMOR quisimos descartar la posibilidad de unión de ligandos delta o kappa selectivos. Para ello utilizamos los prototipos de ligandos kappa y delta, U69,593 y DPDPE, respectivamente (Clark y cols., 1988). En ninguno de los casos pudimos detectar una unión específica de estos compuestos al receptor zfMOR al igual que ocurre en receptores de tipo mu de otras especies (Chen y cols., 1993; Kaufman y cols., 1995; Bolan y cols., 2004). Este hecho confirma la naturaleza mu del receptor.

También se llevaron a cabo estudios utilizando un agonista no selectivo y de tipo no peptídico como es la bremazocina (Wang y cols., 1995) considerado en muchas ocasiones como un compuesto con selectividad kappa (Seki y cols., 1998a). En este caso sí obtuvimos una unión saturable con un valor de $\mathrm{K}_{\mathrm{d}}$ de $2.1 \mathrm{nM}$. Este valor, aunque en el mismo rango, es ligeramente inferior al que se observa en el receptor mu murino $\mathrm{K}_{\mathrm{d}}=0.8 \mathrm{nM}$ o de rata $\mathrm{K}_{\mathrm{d}}=1.58 \mathrm{nM}$ (Mansour y cols., 1997), y es más cercano al valor obtenido para el receptor delta de el mismo animal $\left(\mathrm{K}_{\mathrm{d}}=2.8 \mathrm{nM}\right)$ 
(Wang y cols., 1995; Raynor y cols., 1994). Este dato nos podría indicar que nuestro receptor tiene alguna característica, en su secuencia, que hace que la bremazocina se una con esta afinidad. Se ha determinado que en la unión de la bremazocina a los receptores opioides hay 4 residuos que son fundamentales la lisina 227 , la isoleucina 290, la histidina 291 y la isoleucina 292 (Seki y cols., 1998b) ya que cuando esos residuos, conservados en los receptores opioides clásicos se incorporan en su posición correspondiente en el receptor de tipo ORL, éste adquiere la capacidad de unir la bremazocina. Pese a esto, nuestros resultados apoyan la idea de que aunque estos residuos determinen la capacidad de unión, la afinidad de la misma va a estar influenciada por otros aminoácidos, ya sea por participar directamente en la unión o por ayudar a conseguir la conformación adecuada del receptor.

\subsection{Estudios de competencia o desplazamiento usando ${ }^{3} \mathrm{H}$-Diprenorfina}

Para continuar caracterizando la unión de distintos ligandos opioides al receptor zfMOR y establecer un posible rango de actividad llevamos a cabo estudios de competencia entre distintos agentes opioides y la diprenorfina tritiada (Tabla 4).

Si nos fijamos en el porcentaje de desplazamiento producido por los distintos compuestos utilizados se puede sacar una conclusión muy clara, ninguno de los compuestos peptídicos utilizados en los experimentos de competencia (DAMGO, endomorfina 1, endomorfina 2, CTOP y PLO17) es capaz de desplazar por completo la diprenorfina unida al receptor. Este fenómeno puede tener varias explicaciones. En primer lugar, se puede deber al hecho de que la diprenorfina se puede unir a los receptores que poseen el sitio de unión en el lado interno de las vesículas de 
membrana, como se explicó anteriormente, y que péptidos polares como los utilizados no puedan acceder a dichos sitios de unión (Arden y cols., 1995; Capeyrou y cols., 1997). Sin embargo, una explicación ampliamente utilizada en la bibliografía sería que los ligandos de tipo no peptídico y los ligandos de tipo peptídico no comparten exactamente el mismo sitio de unión al receptor, y podrían ser sitios que se solapen parcialmente (Minami y cols., 1996; Law y cols., 1999). Al no compartir exactamente el mismo sitio de unión al receptor, los ligandos peptídicos no podrían producir un $100 \%$ de desplazamiento cuando se utilicen frente a ligandos de tipo no peptídico, es decir, para poder desplazar completamente a un ligando no peptídico hará falta otro ligando del mismo tipo que reconozca exactamente el mismo sitio de unión. En esta situación un ligando de tipo peptídico produciría un desplazamiento parcial. (Arden y cols. 1995; Meng y cols., 1995; Fukuda y cols., 1995a; Watson y cols., 1996 Capeyrou y cols., 1997). Esto también se ha descrito cuando el ligando radiactivo utilizado es la naloxona y se intenta desplazar con DAMGO; en ese caso DAMGO solo puede desplazar el $50 \%$ de la naloxona unida (Darlison y cols., 1997).

Otro punto importante que se observa en la tabla 4 es que la mayoría de los ligandos utilizados presentan una curva de competencia o desplazamiento característica de dos sitios de unión, sin embargo determinados compuestos presentan un único sitio de unión. En la mayoría de los casos esto se puede explicar atendiendo al tipo de compuesto utilizado. En el caso de compuestos que funcionan como agonistas en el receptor zfMOR se puede asumir que los dos sitios de unión se corresponden con los estados de alta y baja afinidad del receptor, es decir, acoplados o no con las proteínas G, respectivamente. En el caso de los antagonistas, estos no son capaces de reconocer esos dos estados, ya que no producen la activación de la vía de 
transducción de señales. Este sería el caso de CTOP, un antagonista peptídico mu selectivo y de la buprenorfina que en el caso del receptor zfMOR funciona como agonista parcial. Sin embargo hay algunos compuestos como el caso de $\beta$ FNA que siendo un antagonista presenta dos sitios de unión o la endomorfina 2 y PL017 que siendo agonistas solo presentan un sitio de unión. En el caso de los agonistas una posible explicación sería que el rango de concentraciones de ligando frío utilizado no nos permite definir con certeza uno de los sitios de unión del receptor, el de baja o alta afinidad. Sin embargo, autores como Capeyrou (Capeyrou y cols., 1997) obtienen resultados similares para el caso de tres agonistas; dos de ellos producen curvas que se ajustan mejor a dos sitios de unión (DAMGO y morfina) mientras que el tercero, la etorfina, se ajusta mejor a un sitio. Estos autores no dan ninguna importancia a este hecho. Para $\beta$ FNA, la naturaleza covalente de su unión va a afectar a los valores obtenidos, no considerándose como valores reales de afinidad (Raynor y cols., 1994).

Pasando al estudio de los valores concretos de afinidad de los compuestos estudiados se puede observar en tabla 12 una comparación entre los resultados presentados en este trabajo y los que podemos encontrar en la bibliografía.

Una visión general de esta tabla permite apreciar que los valores afinidad obtenidos, medidos como $\mathrm{K}_{\mathrm{i}}$, se ajustan bastante bien a lo publicado correspondiente al receptor opioide mu de otros organismos. En el caso de la etorfina, que es el compuesto con mayor afinidad por el receptor, al igual que ocurre en otras especies (Blake y cols., 1997; Gharagozlou y cols., 2003), los valores publicados son superiores a los del zfMOR; además sólo se da un valor de afinidad. Curiosamente el experimento realizado con las células HEK MT, que expresan el receptor opioide mu 
de rata ofrece también un único valor de afinidad de $1.6 \mathrm{nM}$. En el caso de la morfina y DAMGO se ve como en función de los autores se da un valor de afinidad o dos (alta y baja afinidad). En ambos casos los resultados se ajustan bien a los de otros organismos y se podría decir que en los casos en los que en la bibliografía sólo se da un valor de afinidad éste corresponde con el de alta afinidad,

\begin{tabular}{|c|c|c|c|c|}
\hline & zfMOR & \multicolumn{3}{|c|}{ Otros organismos } \\
\hline Compuesto & Ki (nM) & Organismo & Ki (nM) & Referencia \\
\hline \multirow{2}{*}{ Etorfina } & \multirow{2}{*}{0.0015 y 2.33} & Ratón & 0.3 & Gharagozlou y cols., 2003 \\
\hline & & Humano & 0.23 & Capeyrou y cols., 1997 \\
\hline \multirow{6}{*}{ Morfina } & \multirow{6}{*}{0.52 y 202} & \multirow{2}{*}{ Ratón } & 2.1 & Kaufman y cols., 1995 \\
\hline & & & 2.2 & Gharagozlou y cols., 2003 \\
\hline & & \multirow{3}{*}{ Rata } & 2.5 y 170 & Chaipatikul y cols., 2003 \\
\hline & & & 4 y $128^{*}$ & Zastawny y cols., 1994 \\
\hline & & & 129 & Arden y cols., 1995 \\
\hline & & Humano & 0.4 y 10.4 & Capeyrou y cols., 1997 \\
\hline \multirow{8}{*}{ DAMGO } & \multirow{8}{*}{1.72 y 229} & \multirow[b]{2}{*}{ Ratón } & 4.9 & Kaufman y cols., 1995 \\
\hline & & & 2.65 & Gharagozlou y cols., 2003 \\
\hline & & Bovino & 1.5 & Onoprishvili y cols., 1999 \\
\hline & & \multirow{4}{*}{ Rata } & 1.4 y 140 & Chaipatikul y cols., 2003 \\
\hline & & & 0.6 & Arden y cols., 1995 \\
\hline & & & 1.8 y $113^{*}$ & Zastawny y cols., 1994 \\
\hline & & & 4.2 & Chen y cols., 1993 \\
\hline & & Humano & 0.26 y 7 & Capeyrou y cols., 1997 \\
\hline CTOP & 118 & Rata & 9.7 & Chaipatikul y cols., 2003 \\
\hline PL017 & 104 & Rata & 11 y 330 & Chaipatikul y cols., 2003 \\
\hline \multirow{2}{*}{ DPDPE } & \multirow{2}{*}{$>10000$} & Rata & $>10000$ & Chen y cols., 1993 \\
\hline & & Bovino & $>100$ & Onoprishvili y cols., 1999 \\
\hline U50,488 & & Rata & $>2000$ & Chen y cols., 1993 \\
\hline U69,593 & $>10000$ & Bovino & $>100$ & Onoprishvili y cols., 1999 \\
\hline$\beta$-FNA & 0.17 & Rata & 2.1 & Chen y cols., 1993 \\
\hline Naltrindol & 11.9 & Rata & $15^{*}$ & Zastawny y cols., 1994 \\
\hline
\end{tabular}

Tabla 12: Resumen de los resultados obtenidos en los experimentos de competencia utilizando el compuesto ${ }^{3} \mathrm{H}$-Diprenorfina y distintos ligandos opioides sin marcar. También se muestran los valores obtenidos en otros grupos para los receptores opioides mu de otras especies. El asterisco indica que los valores se han obtenido utilizando ${ }^{3} \mathrm{H}-\mathrm{Naloxona}$

Una excepción sería el valor obtenido por Arden y cols. para la morfina (Arden y cols., 1995), que se aleja hasta en tres ordenes de magnitud del valor obtenido en el receptor de pez cebra. Sin embargo este hecho se puede deber a que 
únicamente se esté detectando el sitio de baja afinidad aunque, puesto que en otros compuestos determinan valores en el orden subnanomolar esto no parece muy probable. Otra posible explicación se ha descrito previamente para la morfina, cuando los experimentos de competencia se realizan sobre células intactas en lugar de sobre extractos de membranas purificadas, donde se puede observar descensos de hasta 35 veces en el valor de afinidad (Toll, 1992).

Otro detalle que se puede destacar de estos resultados es que con el agonista PL017, como se comentó anteriormente, sólo se obtiene un sitio de unión al receptor; esto contrasta con los resultados obtenidos por Chaipatikul y cols. (Chaipatikul y cols., 2003) los cuales presentan dos sitios de unión. Curiosamente realizando el mismo experimento utilizando las células HEK MT obtenemos un único sitio de unión con una $\mathrm{K}_{\mathrm{i}}$ de $150 \mathrm{nM}$, valor muy similar al encontrado en el receptor de pez cebra.

Además de demostrar que ligandos kappa y delta selectivos marcados de forma radiactiva no eran capaces de unirse al receptor zfMOR quisimos corroborar este hecho mediante estudios de competición. Los resultados obtenidos en estos experimentos nos confirman que estos ligandos son incapaces de unirse al receptor, al menos a concentraciones fisiológicas, como ocurre en los receptores mu de otras especies.

Por último, cuando se utilizó el antagonista delta selectivo naltrindol se obtuvo un sitio de unión con una valor de afinidad de $11.9 \mathrm{nM}$. El hecho de que este compuesto se una al receptor zfMOR puede sorprender sin embargo Zastawny y cols. 
(Zastawny y cols., 1994) obtienen un valor muy similar para el receptor de rata. Además, el hecho de que determinados ligandos altamente selectivos se unan a otro tipo de receptores ya ha sido descrito anteriormente en el caso de los receptores de rana en los cuales la selectividad de ciertos compuestos utilizados en mamíferos no es aplicable a dicho organismo. En su caso compuestos como Nor-BNI, $\beta$ FNA o naltrindol no se comportan como selectivos (Newman y cols., 2002). Este hecho además se ha descrito previamente en nuestro grupo ya que el ligando kappa selectivo U69,593 no es capaz de unirse al receptor opioide kappa de pez cebra, zfKOR (Alvar y cols., 2006), y el compuesto delta selectivo DPDPE no se une a los receptores delta zfDOR1 (Rodríguez y cols., 2000) y zfDOR2 (Pinal-Seoane y cols., 2006) del pez cebra.

Para completar el estudio con ligandos selectivos para otro tipo de receptores quisimos estudiar si el ligando endógeno del receptor ORL, la nociceptina, tenía capacidad de unión a zfMOR, como cabía esperar el resultado del experimento fue negativo.

Sin embargo para una gran cantidad de los compuestos utilizados no tenemos datos con los que comparar nuestros resultados ya que, para el caso de los receptores de tipo mu, es más habitual llevar a cabo los experimentos de competencia utilizando como ligando marcado ${ }^{3} \mathrm{H}$-DAMGO, y aunque hay en la bibliografía algún intento de comparación entre resultados de competición utilizando distintos radioligandos (Rothman y cols., 1995) las posibles diferencias de unión entre los distintos ligandos hacen que esta aproximación no sea muy adecuada. El hecho de utilizar ${ }^{3} \mathrm{H}-\mathrm{DAMGO}$ presenta una desventaja ya que al ser un agonista produce cambios estructurales en el 
receptor tras su unión y además es capaz de diferenciar entre receptores acoplados a proteínas G de aquellos que no lo están. Sin embargo en toda la bibliografía revisada no aparece ninguna mención a dos sitios de unión cuando se realizan experimentos de competencia utilizando DAMGO radiactivo. En el caso de nuestros resultados todas las curvas de competencia o desplazamiento obtenidas se ajustaron mejor a un sitio de unión. Puede ser que la complejidad del sistema no permita la distinción de los dos sitios de unión en estas condiciones.

\subsection{Estudios de competencia o desplazamiento usando ${ }^{3}$ H-DAMGO}

De los resultados obtenidos en estos experimentos el primer dato que se puede destacar es que todos los compuestos utilizados, ya sean peptídicos o no, producen un desplazamiento cercano al $100 \%$; este hecho apoya la teoría expuesta anteriormente, al comentar los desplazamientos de ${ }^{3} \mathrm{H}$-diprenorfina. Los resultados concretos se reflejan en la tabla 13 donde se comparan con resultados descritos en la bibliografía.

Se puede observar cómo los resultados obtenidos son muy similares a los que se obtienen para el caso de receptores mu de mamíferos. Sin embargo hay ciertos compuestos en los que se encuentra una mayor diferencia entre los resultados como en el caso del fentanilo, el antagonista mu selectivo CTOP y la dinorfina A. 


\begin{tabular}{|c|c|c|c|c|}
\hline \multirow[b]{2}{*}{ Compuesto } & \multirow{2}{*}{\begin{tabular}{|l|} 
zfMOR \\
Ki (nM) \\
\end{tabular}} & \multicolumn{3}{|c|}{ Otros organismos } \\
\hline & & Organismo & Ki (nM) & Referencia \\
\hline \multirow{3}{*}{ Etorfina } & \multirow{3}{*}{0.4} & Rata & 0.23 & Raynor y cols., 1994 \\
\hline & & \multirow{2}{*}{ Ratón } & 0.10 & Blake y cols., 1997 \\
\hline & & & 2.2 & Gharagozlov y cols., 2003 \\
\hline \multirow{10}{*}{ Morfina } & \multirow{10}{*}{7.9} & Ratón & 1.41 & Blake y cols., 1997 \\
\hline & & \multirow{2}{*}{ Humano } & 4.1 & Wang y cols., $1994 a$ \\
\hline & & & 3.79 & Rothman y cols., 1995 \\
\hline & & \multirow{6}{*}{ Rata } & 1.4 & Satoh y Minami., 1995 \\
\hline & & & 2.7 & Wang y cols., 1993 \\
\hline & & & 5.47 & Rothman y cols., 1995 \\
\hline & & & 7.14 & Thompson y cols., 1993 \\
\hline & & & 14.0 & Raynor y cols., 1994 \\
\hline & & & 19.95 & Mansour y cols., 1997 \\
\hline & & Bovino & 0.9 & Onoprishvili y cols., 1999 \\
\hline \multirow{8}{*}{ DAMGO } & \multirow{8}{*}{4.8} & \multirow{4}{*}{ Rata } & 2 & Raynor y cols., 1994 \\
\hline & & & 0.87 & Satoh y Minami., 1995 \\
\hline & & & 4.17 & Rothman y cols., 1995 \\
\hline & & & 9.80 & Mansour y cols., 1997 \\
\hline & & Humano & 3.02 & Rothman y cols., 1995 \\
\hline & & \multirow{2}{*}{ Ratón } & 2.65 & Gharagozlov y cols., 2003 \\
\hline & & & 1.58 & Blake y cols., 1997 \\
\hline & & Bovino & 2 & Onoprishvili y cols., 1999 \\
\hline \multirow{2}{*}{ Metadona } & \multirow{2}{*}{2} & Rata & 0.72 & Raynor y cols., 1994 \\
\hline & & Ratón & 3.56 & Blake y cols., 1997 \\
\hline \multirow{2}{*}{ Fentanilo } & \multirow{2}{*}{155} & \multirow{2}{*}{ Rata } & 0.39 & Raynor y cols., 1994 \\
\hline & & & 41.63 & Mansour y cols., 1997 \\
\hline \multirow{7}{*}{ Naloxona } & \multirow{7}{*}{1.9} & \multirow{6}{*}{ Rata } & 3.7 & Wang y cols., 1993 \\
\hline & & & 2.44 & Rothman y cols., 1995 \\
\hline & & & 2.74 & Thompson y cols., 1993 \\
\hline & & & 0.93 & Raynor y cols., 1994 \\
\hline & & & 3.9 & Satoh y Minami., 1995 \\
\hline & & & 4.35 & Mansour y cols., 1997 \\
\hline & & Humano & 2.78 & Rothman y cols., 1995 \\
\hline \multirow{2}{*}{ CTOP } & \multirow{2}{*}{100} & Rata & 0.18 & Raynor y cols., 1994 \\
\hline & & Humano & 16 & Wang y cols., $1994 a$ \\
\hline \multirow{4}{*}{ Dinorfina A } & \multirow{4}{*}{9.3} & & 32 & Raynor y cols., 1994 \\
\hline & & Rata & 120 & Satoh y Minami., 1995 \\
\hline & & & 95.5 & Mansour y cols., 1997 \\
\hline & & Humano & 284 & Wang y cols., 1993 \\
\hline Leu-encefalina & 6 & Rata & 3.4 & Raynor y cols., 1994 \\
\hline
\end{tabular}

Tabla 13: Resumen de los resultados obtenidos en los experimentos de competencia utilizando el compuesto ${ }^{3} \mathrm{H}$-DAMGO y distintos ligandos opioides sin marcar. También se muestran los valores obtenidos en otros grupos para los receptores opioides mu de otras especies.

El estudio de la secuencia de los receptores opioides junto con la de otros receptores de tipo GPCR ha permitido determinar que la zona unión de los ligandos a 
estos receptores es poco probable que se encuentre en las regiones extracelulares ya que estas están menos conservadas (Onogi y cols., 1995); parece más probable pensar que la zona de unión se sitúa en un bolsillo hidrofílico en la región transmembrana y que los lazos extracelulares actúen a modo de filtro permitiendo o entorpeciendo la entrada del ligando al sitio de unión (Metzger y Ferguson, 1995). Mediante estudios utilizando receptores quiméricos y mutaciones puntuales se han descrito un gran número de residuos del receptor opioide mu importantes para el reconocimiento o unión de los distintos ligandos al receptor (Chavkin y cols., 2001).

En relación al sitio de unión del ligando, muchos de estos ligandos contienen átomos de nitrógeno que se encuentran cargados positivamente a $\mathrm{pH}$ fisiológico, lo que sugiere que interaccionan con cargas negativas localizadas en las regiones transmembrana (Strader y cols., 1988; Hibert y cols., 1991; Trumpp-Kallmeyer y cols., 1992; Wess, 1993; Hibert y cols., 1993). En este sentido se han encontrado una serie de residuos aminoacídicos que son importantes para que se produzca esta unión. Uno de estos residuos es el aspartato en posición 114 (situado en el segundo dominio transmembrana), el cual se ha visto que esta implicado en la unión de varios ligandos al receptor y además se ha postulado como el responsable de efecto del sodio en la afinidad del ligando por el receptor (Wang y cols., 1991; Ji y Ji, 1991; Kong y cols., 1993a; Kong y cols., 1993b). Se sabe que receptores mu mutantes en ese residuo sufren importantes reducciones en su capacidad de unión de ligandos (Fraser y cols., 1989; Strader y cols., 1988; Ji y Ji., 1991; Savarese y Fraser, 1992 Quintana y cols., 1993), sin embargo parece que ese efecto no es el mismo para agonistas y antagonistas lo que apoya la teoría existente de que los agonistas y antagonistas reconocen dominios no idénticos (Surratt y cols., 1994; Satoh y Minami, 1995; 
Metzger y Ferguson, 1995). Además, este hecho apunta que el cambio producido en los mutantes no provoca cambios conformacionales generalizados (Surratt y cols 1994) ya que en ese caso se esperaría una modificación en las propiedades de unión de los antagonistas. Estos estudios con mutantes también apuntan que es fundamental la existencia de una carga negativa en esa posición (114) para que se produzca un acoplamiento eficiente con las proteínas G por parte de la morfina. También se ha podido comprobar que ese residuo interacciona con la asparragina 332 y que esa interacción es importante para la integración funcional y estructural del receptor (Xu y cols., 1999).

Otro residuo, el aspartato 147 es un residuo compartido entre todos los receptores que unen ligandos con restos amina. Sustituciones en este residuo también van a producir cambios en la unión del ligando y la activación de la señalización intracelular. Los estudios apuntan hacia una interacción directa con el ligando. También aparece una carga positiva en el sexto dominio transmembrana (histidina 297) que se encuentra conservada en los receptores opioides. Esta histidina es crucial en la unión al receptor y junto con el aspartato 147 sirven como puntos de anclaje; también los residuos asparragina 150 y tirosina 326 en los dominios transmembrana 3 y 7 proveen de sitios adicionales para formar puentes de hidrógeno y definir el sitio de unión. Estos dos últimos residuos se ha comprobado que son fundamentales para determinar la afinidad de un gran número de péptidos y alcaloides opioides (Mansour y cols., 1997).

Un residuo que se ha descrito en numerosos trabajos como importante en la selectividad de los receptores opioides de tipo mu es el triptófano en posición 318. 
Éste residuo se localiza alrededor del tercer lazo extracelular, región donde se lleva a cabo la distinción por parte de DAMGO de los receptores mu y kappa (Minami y cols., 1995). La mutación del resto de triptófano por alanina produjo un receptor cuya unión específica fue prácticamente indetectable (Xu y cols., 1999). Otros residuos importantes en la selectividad en esa región son la lisina 303, valina 316 e histidina 319. La lisina 303 es un residuo fundamental para la distinción por parte de la norbinaltorphimina, un compuesto con alta afinidad por el receptor mu, de los receptores kappa y mu como lo demuestra la sustitución del residuo por glutamato, el aminoácido situado en la misma posición en el receptor kappa (Hjorth y cols., 1995). Esta región en torno al tercer lazo extracelular también se ha visto que esta implicada en la discriminación de otros ligandos de tipo peptídico (Minami y cols., 1995).

Pese a que la diferenciación por parte de DAMGO de los receptores de tipo mu y kappa se lleve a cabo, principalmente en la región en torno al tercer lazo extracelular, en el caso de la distinción entre los receptores de tipo delta y mu, ésta se lleva a cabo alrededor del primer lazo extracelular, incluyendo el segundo y parte del tercer dominio transmembrana (Onogi y cols., 1995). Dentro de esta región el residuo de asparragina 127, correspondiente al residuo de lisina 108 en el receptor delta es crítico para esa diferenciación (Fukuda y cols., 1995b). Esto fue demostrado mediante el cambio de la lisina en el receptor delta por asparragina, obteniéndose un receptor con una afinidad notablemente aumentada hacia DAMGO. Este hecho hace pensar que la lisina presente en los receptores de tipo delta está, de alguna manera impidiendo el paso de DAMGO a la zona de unión. (Minami y cols., 1996). Esta región, en torno al primer lazo extracelular también se ha visto implicada en la selectividad hacia otros ligandos de tipo peptídico, pero no así en la discriminación de 
ligandos selectivos de tipo no peptídico (Onogi y cols., 1995). En el caso de la morfina y DPDPE, ligandos selectivos mu y delta, respectivamente, Fukuda y cols. (Fukuda y cols., 1995b) determinan que la discriminación se realiza en la región comprendida entre los segmentos transmembrana 5 y 7 , indicando una pequeña contribución del primer lazo extracelular. Sin embargo, trabajos con el receptor mu humano (Dietrich y cols., 1998) señalan que el cambio de únicamente dos aminoácidos en el primer lazo extracelular provoca un aumento de hasta 7 veces la $\mathrm{K}_{\mathrm{i}}$ de la morfina por el receptor.

Otros residuos que se han estudiado son los triptófanos 173 y 274 así como la tirosina 319 que pueden ser importantes para la unión del antagonista no selectivo diprenorfina pero no del naltrindol o la naloxona, también antagonistas (Décaillot y cols., 2003). También la glicina 131 parece tener importancia en la interacción con agonistas, en este caso por situarse cerca de la zona de unión y no por una interacción directa con el ligando (Fukuda y cols., 1995b)

Todos estos resultados hacen que sea complicado llegar a determinar los residuos que en el caso del receptor de pez cebra están produciendo las pequeñas diferencias encontradas en la farmacología del receptor. Por ejemplo, ya se ha visto la importancia del primer lazo extracelular en el reconocimiento o distinción de compuestos como DAMGO y morfina. En el caso del receptor de pez cebra hay dos sustituciones, la sustitución de una treonina por un ácido aspártico y de una isoleucina por un ácido glutámico en posiciones 129 y 130, respectivamente (Figura 80). 
Estos cambios pueden tener su importancia ya que en la posición correspondiente al residuo 129 en el receptor kappa aparece también un ácido aspártico y en el caso del residuo en posición 130, en el resto de receptores aparecen aminoácidos sin carga. Esta distinta distribución de cargas puede estar influyendo a la unión de algunos de los compuestos, por ejemplo mejorando la afinidad de la dinorfina A, cuyo valor de $\mathrm{Ki}$ es relativamente menor al de otros receptores de tipo mu.

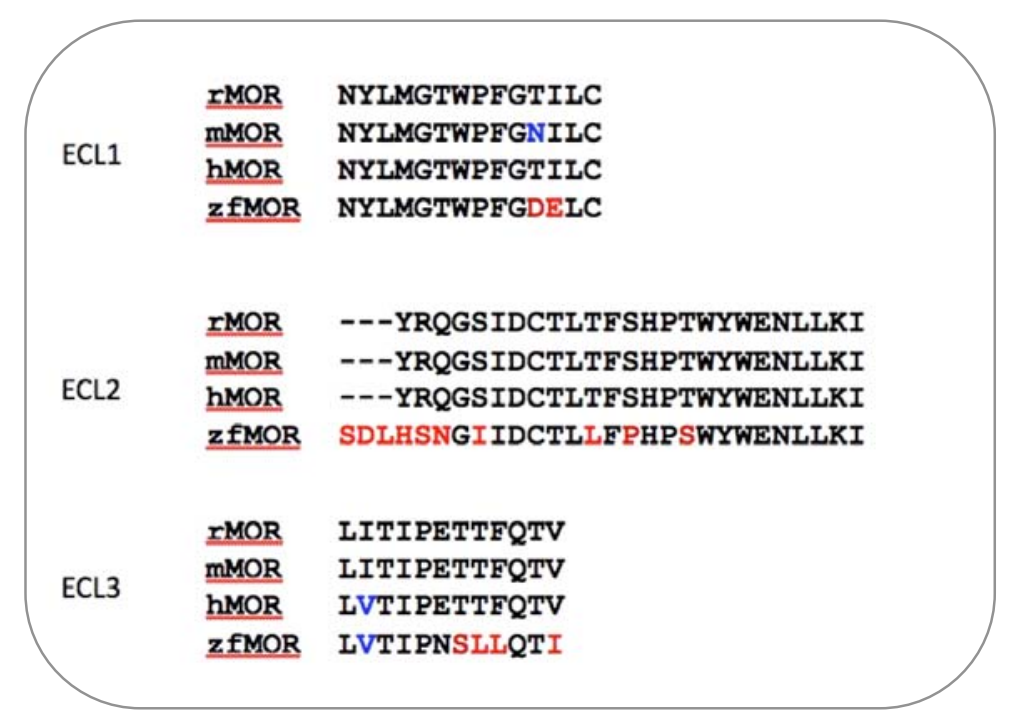

Figura 80: Comparación de los lazos extracelulares de los receptores mu de rata (r), ratón (m), humano (h) y pez cebra (zf). Se pueden obserbar diversos cambios algunos que conservan el carácter del aminoácido y otros que no. En el segundo lazo extracelular se puede destacar la presencia de 3 aminoácidos que no aparecen en los receptores de mamíferos; esto ocasiona un segundo lazo más largo que podría ayudar a explicar algunas de las diferencias encontradas.

También los cambios encontrados en el segundo lazo extracelular pueden ser importantes para ayudar a explicar los resultados obtenidos para la dinorfina A, ya que este lazo se ha visto que contribuye al reconocimiento de ese ligando mediante estudios con quimeras, sin embargo en el caso de agonista U50,488 su capacidad de unión no se modifica (Wang y cols., 1994). En este estudio además se observa que la morfina y DAMGO no presentan modificaciones en su afinidad. Los cambios observados en la secuencia de los lazos extracelulares también podrían ayudar a 
explicar el bajo valor de afinidad presentado por el fentanilo ya que hay estudios que demuestran que cambios en un único aminoácido pueden disminuir los niveles de afinidad hasta 20 veces sin afectar de forma considerable la afinidad de otros ligandos; esto se ha visto que ocurre así, por ejemplo, en el caso del fentanilo, naltrindol y CTAP (Bonner y cols., 2000). Al igual que pasa con CTAP su análogo CTOP también se ve afectado por sustituciones que por el contrario no afectan a la capacidad de unión de otros antagonistas como la naloxona o la diprenorfina. La diferencia estructural entre CTOP, un péptido, y los otros antagonistas, así como la disminuida afinidad que muestra este compuesto en presencia de iones metálicos y GTP (algo propio de los agonistas) (Hawkins y cols., 1989) puede hacer que éste se vea más afectado por los pequeños cambios que encontramos en la secuencia de zfMOR obteniendo valores de afinidad claramente inferiores a los encontrados en mamífero.

Los valores obtenidos para el receptor opioide mu de pez cebra son además casi idénticos la los obtenidos para el receptor mutante. Este hecho nos está indicando que a pesar de que el segundo lazo extracelular sea 3 aminoácidos más largo que en el caso del receptor de mamífero, esto no produce un cambio conformacional suficientemente grande como para que se produzca una variación en la farmacología del receptor, al menos para el conjunto de ligandos utilizados en este estudio.

\subsection{Ensayos de actividad del receptor por $\left[{ }^{35} \mathrm{~S}\right]-\mathrm{GTP} \gamma \mathrm{S}$}

Para poder determinar la posible activación del receptor tras la unión del ligando realizamos el ensayo de unión de $\left[{ }^{35} \mathrm{~S}\right]-\mathrm{GTP} \gamma \mathrm{S}$. De los datos obtenidos a una 
concentración saturante del ligando podemos observar que al igual que pasa en los receptores opioides de otras especies la naloxona y la diprenorfina actúan como antagonistas y al igual que en los receptores de tipo mu CTOP también actúa como antagonista (Figura 40) (Mansour y cols., 1997; Thompson y cols., 1993; Lee y cols., 1999). Esto se observa ya que presentan una activación del receptor que no llega al 10 $\%$ del nivel de activación en ausencia del ligando. Otros compuestos utilizados como la bremazocina, y la deltorfina también están funcionando como antagonistas en zfMOR mientras que la buprenorfina sería un agonista parcial débil (Zaki y cols., 2000). En el caso del naltrindol, parece que podría comportarse como un agonista inverso. El concepto de agonista inverso se aplica cuando se tiene un receptor que se encuentra activado constantemente a nivel basal, es decir, en ausencia de ligando hay una cierta activación de las proteínas G (Wang y cols., 1994c; el Kouhen y cols., 2001). En el caso de un antagonista, éste se uniría al receptor y no produciría ninguna respuesta, sin embargo un agonista inverso es capaz de reducir la actividad basal del receptor, observándose por tanto valores negativos de activación. La presencia de esta actividad constitutiva en los receptores opioides es previamente conocida y permite que haya un reciclaje continuo de los receptores en membrana, ya que la activación del receptor suele ir acompañada de su internalización (Koch y cols., 2001; Johnson y cols., 2006). El agonismo inverso no se había descrito para el naltrindol que funciona como antagonista para los receptores de tipo delta, sin embargo el hecho de que se una con tanta afinidad al receptor mu de pez cebra y que ciertos derivados del naltrindol como el compuesto HS378 actúen como agonistas inversos (Labarre y cols., 2000) podrían explicar los resultados obtenidos. El naltrindol pondría al receptor en un estado conformacional distinto al originado por agonistas y antagonistas y que no es posible alcanzar en el caso del receptor delta por las 
características de su estructura terciaria (Salamon y cols., 2002). También en el caso de otro compuesto de tipo delta selectivo, TIPP, se ha demostrado que se puede comportar como agonista, antagonista o agonista inverso, dependiendo de las condiciones del ensayo y del momento de la señal de transducción estudiado (Martin y cols, 2002).

En el caso de los compuestos mu como DAMGO, fentanilo y morfina se comportan como agonistas como ocurre en mamífero y lo mismo ocurre para los péptidos endógenos utilizados: dinorfina A, Leu-encefalina y Met-encefalina.

También llevamos a cabo curvas de activación para determinados compuestos. Los valores obtenidos en estos experimentos tanto de potencia $\left(\mathrm{EC}_{50}\right)$ como de eficacia (activación máxima) se muestran comparados con los encontrados en los receptores mu de otros organismos en la tabla 14.

Hay varios detalles que pueden llamar la atención en esta tabla. En primer lugar hay una gran variabilidad de los datos tanto dentro de un mismo organismo como entre distintos organismos. Respecto a los valores concretos destaca que la activación máxima producida por DAMGO y morfina es similar; este hecho esta en contraposición con la idea de que la morfina es un agonista parcial respecto a DAMGO que aparece en ciertas referencias (Smith y Rance, 1983; Ingram y cols., 1998; 50 Chavkin y cols., 2001; Yue y cols., 2006; 39 Johnson y cols., 2006; Kelly y cols., 2008) y que se puede observar en la tabla con los resultados de Alt y cols. (Alt y cols., 1998). Estos autores determinan la capacidad máxima de activación resultando ser la de la morfina un $49 \%$ inferior a la de DAMGO. Sin embargo numerosos 
trabajos describen que la morfina actúa como un agonista completo, por ejemplo en un estudio con membranas de células de neuroblastoma (Traynor y Nahorski, 1995) o que DAMGO y morfina tienen una eficacia similar al activar a las proteínas G de tipo $\mathrm{G}_{\mathrm{i}(1 / 2)}, \mathrm{G}_{0}$ y $\mathrm{G}_{\mathrm{i}(3)}$ (Burford y cols., 1998); los resultados de Segredo y cols. (Segredo y cols., 1997) también apoyan la idea de que la morfina es un agonista completo ya que el mismo tratamiento con morfina y DAMGO produce una activación de 262 y 281 $\%$, respectivamente, sobre el nivel de activación basal. En la tabla tenemos otro ejemplo con los resultados de Bolan y cols. (Bolan y cols., 2004). Estas diferencias se pueden deber al nivel de la señalización intracelular que se ha estudiado en cada caso. Por ejemplo en el caso del trabajo de Johnson y cols. (Johnson y cols., 2006) lo que observan es que DAMGO produce mayores corrientes de potasio, al activar los canales GIRK (los cuales son activados por el dímero $\beta \gamma$ de la proteína G (Darlison y cols., 1997)), que la morfina por lo que lo definen como agonista parcial; sin embargo estos autores no comparan la capacidad de activación de las proteínas G.

También consideramos importante nuestro resultado en el que observamos que el fentanilo tiene un valor de potencia muy baja, es decir, obtenemos un valor de $\mathrm{EC}_{50}$ muy alto, en el orden micromolar, mientras que en mamíferos se encuentra en el orden nanomolar. Se puede observar que el valor de potencia para la Leu-encefalina en el caso de la rata también está alrededor del orden micromolar, sin embargo este hecho es aceptable para los ligandos endógenos, los cuales se liberan en zonas muy puntuales, obteniéndose altas concentraciones en el lugar donde se encuentra el receptor. El resultado obtenido para el fentanilo puede ser un reflejo de la poca afinidad por el receptor encontrada en los experimentos de competencia, sin embargo, como se ha visto en resultados y se comentará más adelante en el caso de la inhibición 
de la adenilato ciclasa el valor de $\mathrm{EC}_{50}$ obtenido está en el orden nanomolar y es incluso menor que el de ratón.

\begin{tabular}{|c|c|c|c|c|c|c|}
\hline & $\overline{z f N}$ & $\overline{\mathbf{O R}}$ & & Otro & orga & hismos \\
\hline Compuesto & $\begin{array}{l}\text { EC50 } \\
(\mathrm{nM}) \\
\end{array}$ & $\begin{array}{l}\text { M.A } \\
(\%) \\
\end{array}$ & Organismo & $\begin{array}{l}\text { EC50 } \\
(\mathrm{nM}) \\
\end{array}$ & $\begin{array}{l}\text { M.A } \\
(\%) \\
\end{array}$ & Referencia \\
\hline \multirow{5}{*}{ DAMGO } & \multirow{5}{*}{83} & \multirow{5}{*}{155} & \multirow{3}{*}{ Rata } & 145 & $100 *$ & Alt y cols., 1998 \\
\hline & & & & 1.53 & - & Bonner y cols., 2000 \\
\hline & & & & 59 & - & Xu y cols., 1999 \\
\hline & & & Ratón & 68 & $100 *$ & Bolan y cols. 2004 \\
\hline & & & Humano & $\begin{array}{l}243 \mathrm{G} \alpha i 1 \\
132 \mathrm{G} \alpha 0 \mathrm{~A}\end{array}$ & $100 *$ & Saidak y cols., 2006 \\
\hline \multirow{5}{*}{ Morfina } & \multirow{5}{*}{46} & \multirow{5}{*}{184} & \multirow{3}{*}{ Rata } & 118 & 41 & Alt y cols., 1998 \\
\hline & & & & 51 & - & Bonner y cols., 2000 \\
\hline & & & & 81 & - & Xu y cols., 1999 \\
\hline & & & Ratón & 23 & 102 & Bolan y cols. 2004 \\
\hline & & & Humano & $\begin{array}{l}213 \mathrm{G \alpha il} \\
89 \mathrm{G} \alpha 0 \mathrm{~A}\end{array}$ & $\begin{array}{l}66 \\
88 \\
\end{array}$ & Saidak y cols., 2006 \\
\hline \multirow{3}{*}{ Endomorfina 1} & \multirow{3}{*}{112} & \multirow{3}{*}{80} & Rata & 293 & 65 & Alt y cols., 1998 \\
\hline & & & Ratón & 26 & 98 & Bolan y cols. 2004 \\
\hline & & & Humano & 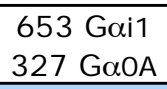 & $\begin{array}{l}86 \\
85 \\
\end{array}$ & Saidak y cols., 2006 \\
\hline \multirow{3}{*}{ Endomorfina 2} & \multirow{3}{*}{83} & \multirow{3}{*}{69} & Rata & 521 & 63 & Alt y cols., 1998 \\
\hline & & & Ratón & 72 & 124 & Bolan y cols. 2004 \\
\hline & & & Humano & $\begin{array}{l}252 \text { Gail } \\
421 \text { G } \alpha 0 A\end{array}$ & $\begin{array}{l}89 \\
91\end{array}$ & Saidak y cols., 2006 \\
\hline \multirow{3}{*}{ Met-encefalina } & \multirow{3}{*}{106} & \multirow{3}{*}{167} & \multirow{2}{*}{ Rata } & 185 & 97 & Alt y cols., 1998 \\
\hline & & & & 40 & 105 & Remmers y cols., 2000 \\
\hline & & & Humano & $\begin{array}{l}504 \text { Gail } \\
278 \mathrm{G} \alpha 0 A\end{array}$ & $\begin{array}{c}103 \\
96 \\
\end{array}$ & Saidak y cols., 2006 \\
\hline \multirow[b]{3}{*}{ Leu-encefalina } & \multirow[b]{3}{*}{156} & \multirow[b]{3}{*}{166} & \multirow{2}{*}{ Rata } & 956 & 117 & Alt y cols., 1998 \\
\hline & & & & 122 & 101 & Remmers y cols., 2000 \\
\hline & & & Humano & $\begin{array}{l}1011 \mathrm{G \alpha i1} \\
842 \mathrm{G} \alpha 0 \mathrm{~A}\end{array}$ & $\begin{array}{c}101 \\
99\end{array}$ & Saidak y cols., 2006 \\
\hline \multirow{3}{*}{ Fentanilo } & \multirow{3}{*}{1059} & \multirow{3}{*}{151} & Rata & 23 & - & Bonner y cols., 2000 \\
\hline & & & Ratón & 16 & 145 & Bolan y cols. 2004 \\
\hline & & & Humano & $\begin{array}{l}119 \mathrm{G} \alpha i 1 \\
67 \mathrm{G} \alpha 0 \mathrm{~A}\end{array}$ & $\begin{array}{l}69 \\
72 \\
\end{array}$ & Saidak y cols., 2006 \\
\hline Dinorfina A & 99 & 130 & Ratón & 34 & 109 & Bolan y cols. 2004 \\
\hline
\end{tabular}

Tabla 14: Resumen de los resultados obtenidos (potencia y eficacia en la activación de las proteínas G) en los experimentos de activación del receptor por $\left[{ }^{35} \mathrm{~S}\right]-\mathrm{GTP} \gamma \mathrm{S}$ para varios ligandos. También se muestran los valores obtenidos en otros grupos para los receptores opioides mu de otras especies. En el caso del receptor mu de humano los autores determinan, de forma independiente, la activación de las subunidads $\mathrm{G \alpha}_{\mathrm{i} 1}$ y $\mathrm{G \alpha}_{0 \mathrm{~A}}$. Los asteriscos indican que los autores toman ese valor como $100 \%$ de activación, normalizando los demás resultados en relación a ese compuesto.

Hay un gran número de dominios y residuos específicos distribuidos a lo largo de la secuencia de los receptores opioides que pueden contribuir a la correcta 
señalización del receptor (Surrat y Adams, 2005) (Figura 81). Uno de los dominios altamente conservados entre los GPCR es la secuencia D/ERY, localizada entre el tercer dominio transmembrana y el segundo lazo intracelular. Este dominio es fundamental en el control de la activación del receptor (Arnis y cols., 1994; Scheer y cols., 1997; Ballesteros y cols., 1998; Wess, 1998; Gether, 2000) ya que contribuye a mantenerlo en un estado inactivo. La carga negativa del aspartato/glutamato (según el receptor) va a estabilizar la conformación inactiva mediante interacciones intramoleculares. Uno de los residuos implicados en esta estabilización es la arginina del mismo dominio sin embargo hay otros residuos implicados, alejados en la secuencia lineal pero muy próximos cuando se adquiere la estructura terciaria de la proteína. Uno de esos residuos está situado en el sexto dominio transmembrana y aunque no es un residuo conservado, si está conservada su carga negativa (Ballesteros y cols., 1998). Receptores opioides en los que se eliminó la carga positiva del dominio D/ERY ocasionaron que la naloxona y análogos actuaran como agonistas inversos (Li y cols., 2001). Otro dominio importante en la activación de los receptores es la secuencia "XBBXXB" en la que B representa un residuo de aminoácido básico y X representa un residuo no básico (para los receptores opioides la secuencia es LRRITR). Esta secuencia se localiza en la porción carboxilo terminal del tercer lazo intracelular y permite definir claramente el comienzo del sexto domino transmembrana. Esta contribución al posicionamiento del dominio transmembrana probablemente sea importante en el correcto empaquetamiento de todas las hélices que conforman el bolsillo de unión y para el acoplamiento con las proteínas G (Cotecchia y cols., 1990; Samama y cols., 1993). La mutación del residuo menos conservado de esta secuencia (posición 6.34 según el sistema de nomenclatura de Ballesteros y Weinstein (1995))produjo un receptor con un incremento de 100 veces 
de afinidad por agonistas, sin modificarse la de los antagonistas (Cotecchia y cols., 1990; Samama y cols., 1993; Egan y cols., 1998) además esos receptores frecuentemente tenían una activación constitutiva. Mutaciones en el receptor opioide de tipo mu en ese dominio revelan que cada poción del domino contribuye de forma diferente a la señalización. Mutación en el residuo 6.35 origina un receptor con la mitad de actividad cuando se utiliza DAMGO. La mutación del residuo 6.34 (cambio de treonina por alanina) incrementa la potencia de la morfina y PL017 sin afectar a la de DAMGO, mientras que los mutantes R6.31A e I6.33A presentan una reducción de la potencia de DAMGO sin modificaciones en la de la morfina o PL017 (Chaipatikul y cols., 2003).

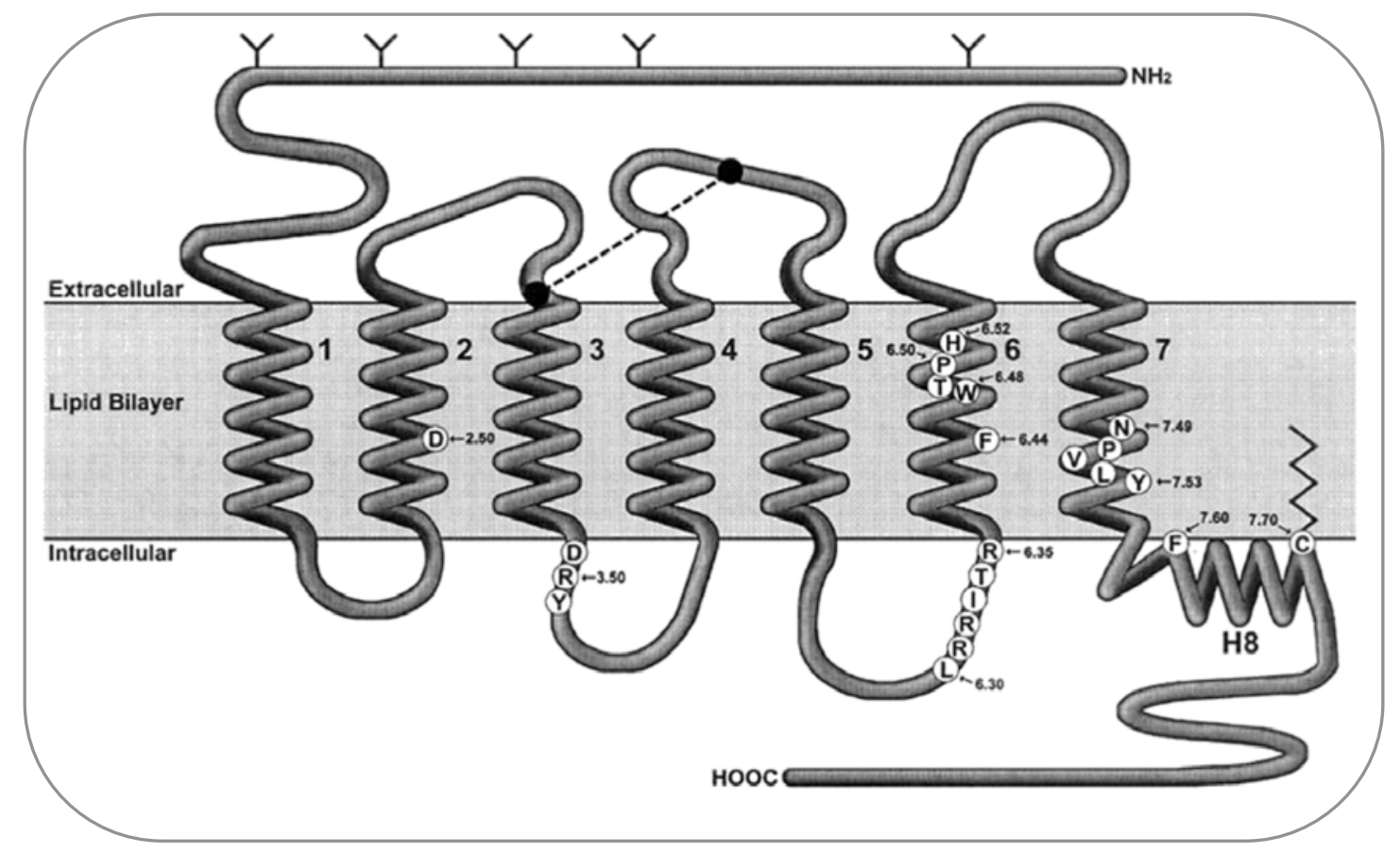

Figura 81: Estructura de un receptor de tipo GPCR, aparecen resaltadas las posiciones de dominios y residuos importantes para la funcionalidad del receptor. El sistema de nomenclatura utilizado es el propuesto por Ballesteros y Weinstein (1995). Figura tomada de Surrat y Adams, 2005.

Otra secuencia que es importante en los GPCR y en particular en los receptores opioides es el dominio aromático (FXXXWXXXH). Sustituciones en este dominio originan mutantes en los cuales antagonistas de tipo alcaloide pueden 
funcionar como agonistas parciales, por ejemplo, la bremazocina, sin modificarse la actividad del antagonista CTOP (Spivak y cols., 1997; Meng y cols., 2000). En el caso de la morfina, en el mutante W6.48A se redujo su actividad intrínseca, incluso a pesar de que su afinidad por el receptor aumentó hasta 44 veces, mientras que en la mutación W6.48F no se produjo cambio alguno.

De lo anteriormente expuesto puede deducirse que la interpretación de los datos referentes a la activación de los receptores no es sencilla. Un gran número de trabajos proponen estructuras fundamentales para el correcto funcionamiento sin embargo los resultados mediante mutaciones puntuales no aclaran el papel que cada uno de los residuos juega en la funcionalidad del receptor. Además se ha propuesto que los dominios involucrados en la activación pueden ser diferentes en función del agonista utilizado (Chaipatikul y cols., 2003). En el caso de los receptores mu hay una gran cantidad de residuos que se han considerado como importantes en el acoplamiento con las proteínas G, entre ellos D114, Y106, Y166, D164, S196, S268, K273, K275 R280, H297 (Surratt y Adams., 2005). Algunos de estos residuos también se han considerado importantes para la unión del ligando, aunque esto no debe extrañar ya que modificaciones en una región de la proteína como la región extracelular pueden tener grandes repercusiones en otra región como puede ser la intracelular. Todos estos residuos se ha visto que están conservados en el receptor de pez cebra así como los dominios descritos anteriormente. Aún así podemos ver diferencias en la capacidad de activación de distintos ligandos, aunque en la mayoría de los casos no son muy grandes; en el caso del fentanilo en muy llamativa. Este hecho se puede atribuir a cambios en la secuencia de zfMOR ya que se ha demostrado que el cambio en un único aminoácido, por ejemplo en el caso del aspartato 114, 
puede hacer que aumente de forma notable la $\mathrm{EC}_{50}$ del agonista empleado (Xu y cols., 1999).

\subsection{Estudio de la inhibición de la adenilato ciclasa}

También se utilizó como método para determinar la capacidad de activación del receptor, por parte de distintos ligandos, el ensayo de la inhibición de la adenilato ciclasa. Los resultados obtenidos tanto en el receptor de pez cebra en este trabajo, como por otros autores en distintos organismos se encuentran resumidos en la tabla 15.

Los resultados obtenidos para el receptor zfMOR se ajustan bastante bien a lo publicado para otros receptores de tipo mu. Cuando realizamos un pretratamiento con toxina pertúsica, que inhibe mediante un proceso de ribosilación (Kurose y cols., 1983; Abood y cols., 1987) a un gran número de subunidades alfa conseguimos bloquear el efecto de la etorfina. Este hecho nos dice que el receptor opioide mu de pez cebra, al igual que los receptores opioides de otros tipos y especies, se acopla con proteínas $G$ del tipo $G_{i} / G_{0}$, el grupo de proteínas $G$ sensibles a toxina pertúsica. En el caso del receptor murino Blake y cols., 1997 consiguen una abolición total del efecto de la etorfina. Este resultado, sin embargo, no nos hace descartar la posibilidad de que también se produzca acoplamiento con el tipo de proteínas $G$ insensibles a toxina pertúsica (Burford y cols., 1997).

En el caso de la $\beta$-endorfina el valor obtenido fue de $593 \mathrm{nM}$. Este valor se aleja mucho de los valores obtenidos para el resto de los ligandos, sin embargo, este 
valor es aceptable para un ligando de tipo endógeno ya que éstos se liberan a muy altas concentraciones justo en la hendidura sináptica. Este valor es además muy similar al encontrado en el receptor de ratón, 526 nM. Sin embargo el valor de máxima inhibición para estos dos organismos es más dispar, siendo $55.4 \%$ para el pez cebra y $71 \%$ para ratón (Gharagozlov y cols., 2003).

\begin{tabular}{|c|c|c|c|c|c|c|}
\hline & \multicolumn{2}{|c|}{ zfMOR } & \multicolumn{4}{|c|}{ Otros organismos } \\
\hline Compuesto & $\begin{array}{l}\text { EC50 } \\
\text { (nM) }\end{array}$ & $\begin{array}{l}\text { Max. } \\
\text { Inh. } \\
(\%)\end{array}$ & Organismo & $\begin{array}{l}\text { Ec50 } \\
(n M)\end{array}$ & $\begin{array}{l}\text { Max. } \\
\text { Inh. } \\
(\%)\end{array}$ & Referencia \\
\hline \multirow{5}{*}{ Etorfina } & \multirow{5}{*}{0.013} & \multirow{5}{*}{ 39\# } & \multirow{4}{*}{ Ratón } & 0.6 & 60 & Gharagozlov y cols. 2003 \\
\hline & & & & 0.044 & 84 & Blake y cols., 1997 \\
\hline & & & & 0.135 & $100 *$ & Zaki y cols., 2000 \\
\hline & & & & 0.37 & - & Keith y cols., 1996 \\
\hline & & & Humano & 0.31 & 93 & Capeyrou y col., 1997 \\
\hline \multirow{13}{*}{ DAMGO } & \multirow{13}{*}{23.4} & \multirow{13}{*}{59} & \multirow{4}{*}{ Ratón } & 27 & 60 & Kaufman y cols., 1995 \\
\hline & & & & 35 & 58 & Gharagozlov y cols., 2003 \\
\hline & & & & 3.3 & & Blake y cols., 1997 \\
\hline & & & & 4.81 & - & Keith y cols., 1996 \\
\hline & & & \multirow{5}{*}{ Rata } & 0.20 & $>90$ & Arden y cols., 1995 \\
\hline & & & & 3.0 & & Seki y cols., 1998 \\
\hline & & & & 8.3 & 87 & Chaipatikul y cols., 2003 \\
\hline & & & & - & 20 & Chen y cols., 1993 \\
\hline & & & & 0.5 & 100 & Segredo y cols., 1997 \\
\hline & & & \multirow{2}{*}{ Humano } & 11 & 84 & Capeyrou y col., 1997 \\
\hline & & & & - & $30(1 \mu \mathrm{M})$ & Wang y cols., 1993 \\
\hline & & & Bovino & - & 40 & Onoprishvili y col., 1999 \\
\hline & & & $\begin{array}{l}\text { Catostomus } \\
\text { commersoni }\end{array}$ & & $74(1 \mu \mathrm{M})$ & Darlison y cols., 1997 \\
\hline \multirow{9}{*}{ Morfina } & \multirow{9}{*}{10} & \multirow{9}{*}{64} & \multirow{5}{*}{ Ratón } & 29 & 60 & Kaufman y cols., 1995 \\
\hline & & & & 17 & 41 & Gharagozlov y cols., 2003 \\
\hline & & & & 2.3 & 75 & Blake y cols., 1997 \\
\hline & & & & 16.47 & - & Keith y cols., 1996 \\
\hline & & & & 4.92 & $101^{*}$ & Zaki y cols., 1999 \\
\hline & & & \multirow{3}{*}{ Rata } & 13 & 85 & Chaipaticul y cols., 2003 \\
\hline & & & & 0.5 & 93 & Segredo y cols., 1997 \\
\hline & & & & 1.1 & 76 & Arden y cols., 1995 \\
\hline & & & Humano & 65 & 76 & Capeyrou y cols., 1997 \\
\hline Metadona & 4.71 & 56 & Ratón & 9.6 & 85 & Blake y cols., 1997 \\
\hline PL017 & 2.1 & 49 & Rata & 11 & 85 & Chaipatikul y cols., 2003 \\
\hline \multirow{2}{*}{ Fentanilo } & \multirow{2}{*}{0.61} & \multirow{2}{*}{75} & \multirow{2}{*}{ Ratón } & 8.4 & 69 & Gharagozlov y cols., 2003 \\
\hline & & & & 2.06 & 99* & Zaki y cols., 1999 \\
\hline Nalorfina & 8.25 & 43 & Ratón & 2.7 & 50 & Gharagozlov y cols., 2003 \\
\hline$\beta$-endorfina & 593 & 55 & Ratón & 526 & 71 & Gharagozlov y cols., 2003 \\
\hline Buprenorfina & 1.89 & 55 & Ratón & 1.55 & 79 & Zaki y cols., 1999 \\
\hline U50,488 & 1623 & 60 & $\begin{array}{l}\text { Catostomus } \\
\text { commersoni }\end{array}$ & - & $25(1 \mu \mathrm{M})$ & Darlison y cols., 1997 \\
\hline
\end{tabular}

Tabla 15: Resumen de los resultados obtenidos (potencia y inhibición máxima) en los experimentos de inhibición de la adenilato ciclasa para varios ligandos. También se muestran los valores obtenidos en otros grupos para los receptores opioides mu de otras especies. Los asteriscos indican que los autores toman el valor obtenido para etorfina como $100 \%$ de activación, normalizando los demás resultados en relación a ese compuesto. 
También pudimos observar como el tratamiento simultaneo de la etorfina con distintos antagonistas produce un movimiento de la curva hacia la derecha (Arden y cols., 1995; Alt y cols., 1998) este hecho apoya el efecto directo de la etorfina sobre el receptor.

Puesto que la señalización por parte de la adenilato ciclasa es un proceso posterior a la activación de las proteínas $\mathrm{G}$ podemos decir que los dominios que son importantes para la correcta activación de las proteínas $\mathrm{G}$ influyen de forma indirecta en los resultados obtenidos al estudiar las variaciones en las concentraciones de AMPc producidas por la activación del receptor. Sin embargo además de los trabajos comentados anteriormente existen algunos otros que estudian el efecto de modificaciones en la secuencia del receptor en la señalización por AMPc. En este sentido se sabe que modificaciones en el tercer lazo extracelular producen variaciones en los valores de $\mathrm{EC}_{50}$ obtenidos mediante la técnica de AMPc (Seki y cols., 1998b). Además se ha comprobado que la deleción de los últimos 33 aminoácidos de la secuencia del receptor mu no produce variación en los niveles de afinidad del receptor por la morfina, DAMGO o la naloxona; sin embargo el estudio del acoplamiento a la adenilato ciclasa reveló que mientras que la morfina mantenía su capacidad de inhibir la acumulación de AMPc, DAMGO perdió mucha de su capacidad (Surratt y cols., 1994).

Los experimentos realizados con el receptor zfMOR y el nuestro mutante delecionado en el segundo lazo extracelular nos confirman que además de que la deleción no tiene efectos en la capacidad de unión de los ligandos, tampoco está afectando a la capacidad de activación del receptor. 
Por último también estudiamos la capacidad de activar el receptor de distintos ligandos endógenos tanto en el receptor mutado como en el wild type. De característica importante de los resultados obtenidos (Figura 54) es que ninguno de los compuestos empleados se comporta sustancialmente de forma distinta en ambos receptores, salvo la dinorfina A de pez cebra, en la cual se observa un claro desplazamiento de la curva hacia la izquierda. Podemos decir, atendiendo a estos resultados, que la dinorfina A humana se une de interacciona de forma ligeramente diferente a como lo hace la dinorfina A de pez cebra y además la distinta longitud del segundo lazo extracelular entre los dos receptores también está afectando a la capacidad de activación de la dinorfina A de pez cebra.

\subsection{Estudio de la capacidad de unión del $\mathrm{Zn}^{2+}$ al receptor zfMOR}

Se ha demostrado que los receptores opioides, y en particular los receptores de tipo mu presentan sitios de unión para los iones zinc (Fowler y cols., 2004). Este hecho se ha utilizado como una manera de determinar las distancias entre distintos residuos aminoacídicos como aproximación al estudio de la estructura de los receptores.

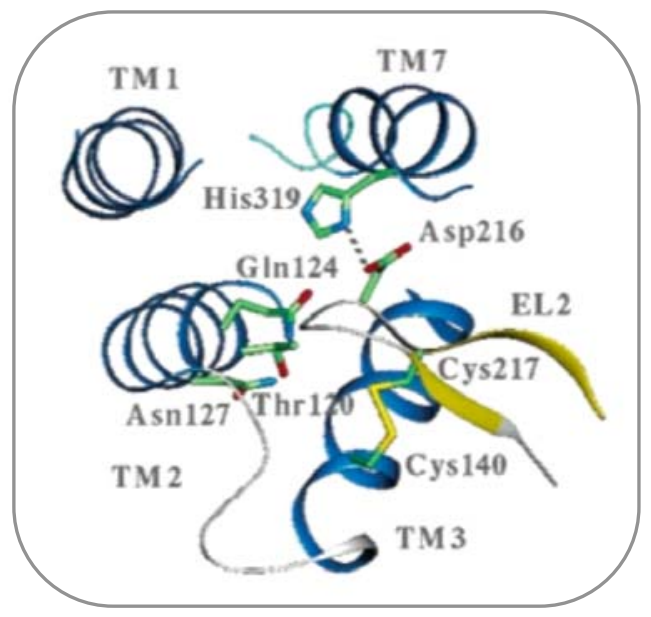

Figura 82: Modelo de la estructura de la región extracelular de los dominios transmembrana primero (TM1), segundo (TM2), tercero (TM3) y séptimo (TM7) del receptor mu de rata. Se puede ver como el segundo lazo extracelular (EL2) se encuentra unido al tercer dominio transmembrana mediante un puente disulfuro entre los residuos de cisteína 140 y 217 y al séptimo dominio transmembrana mediante la interacción del aspartato 216 y la histidina 319. Es precisamente esta última zona la que formaría el sitio de unión del zinc. Tomado de Fowler y cols., 2004 
De los resultados obtenidos podemos determinar que la estructura presente en los receptores opioides mu de mamífero que involucra una serie de residuos (Figura 82) también se encuentra presente en el receptor del pez cebra. Además hemos demostrado que las modificaciones estructurales producidas por la deleción de tres aminoácidos en el extremo amino del segundo lazo extracelular no son suficientes para que desaparezca esta estructura. Estos datos además están avalados por los resultados obtenidos en los experimentos de competencia utilizado ${ }^{3} \mathrm{H}-\mathrm{DAMGO}$ con los receptores wild type y mutante.

\subsection{Estudios de internalización}

Los procesos de internalización en los receptores opioides y en particular en los receptores de tipo mu han sido ampliamente estudiados debido a su importancia en los procesos de tolerancia y desensibilización. En contraposición a la teoría existente de que la internalización contribuía al desarrollo de tolerancia mediante la reducción del número de receptores señalizantes, estudios recientes apuntan a que la internalización del receptor opioide reduce el desarrollo de desensibilización del receptor y la tolerancia (Koch y Höllt, 2008).

En consecuencia, dada la gran importancia del proceso de internalización en el desarrollo de la tolerancia quisimos determinar si el receptor zfMOR sufría internalización dependiente de agonista como en el caso de los receptores opioides de mamífero estudiados. 
Cuando analizamos la capacidad de la etorfina, un compuesto que se conoce que produce una rápida internalización de los receptores opioides, de internalizar el receptor zFMOR, observamos una disminución en la fluorescencia de membrana (Figura 60) con respecto a la condición basal, en la cual el receptor se encuentra en la membrana plasmática (Figura 58) (Keith y cols., 1996; Segredo y cols., 1997; Wang y cols., 2003). Este hecho indica que una vez los receptores han sido activados por el ligando se produce una cascada de señalización intracelular que conduce, entre otras cosas, a la internalización del receptor en vesículas de endocitosis. Esas vesículas endocíticas son las que observamos, con típicos patrones punteados de fluorescencia en el interior celular (Wang y cols., 2003). Sin embargo, en ocasiones en las células control aparece cierto número de vesículas intracelulares (Figura 58) que corresponden a una internalización basal del receptor (Wang y cols., 2003; Johnson y cols., 2006) producto de una actividad constitutiva basal del receptor opioide mu (Wang y cols., 1994c y 2000). El porcentaje de internalización obtenido mediante análisis de citometría de flujo para el tratamiento de etorfina (etorfina $1 \mu \mathrm{M}, 30 \mathrm{~min}$., $37^{\circ} \mathrm{C}$ ) fue de un $39 \%$. Este valor se encuentra en el mismo orden al encontrado por otros grupos en el caso del receptor mu murino o de rata (Keith y cols., 1996; Whistler y cols., 1999; Wang y cols., 2003; Qiu y cols., 2003) y también coincide con el obtenido en este trabajo utilizando el receptor mu de rata como control de la internalización.

Los resultados obtenidos al estudiar la unión del compuesto mu selectivo DAMGO al receptor zfMOR implican que tiene una clara actividad opioide de tipo mu. En este sentido estudiamos la capacidad de producir internalización de este compuesto peptídico. Como se observa en la figura 59 el tratamiento con DAMGO 
también produjo la internalización del receptor que mediante la cuantificación por citometría de flujo resultó ser de un $17 \%$ respecto al control. Esta disminución de receptores en membrana es ligeramente inferior a la encontrada por otros grupos en los receptores de rata y ratón. En la bibliografía se encuentra valores de $37 \%$ de internalización (Whistler y cols., 1999), 52 \% en el caso de un tratamiento con DAMGO $10 \mu \mathrm{M}$ (Johnson y cols., 2006) ó $50 \%$ para una incubación de $1 \mathrm{~h}$ (el Kouhen y cols., 2001). Sin embargo en muchos de los casos simplemente se ofrece una foto de microscopía confocal demostrando la internalización y sin hacer referencia a la cuantificación (Burford y cols., 1999; Arden y cols., 1995; Keith y cols., 1996; Segredo y cols., 1997). En el caso del control que hemos utilizado (receptor mu de rata) parece que el nivel de internalización obtenido (Figuras 62 y 63 para DAMGO y etorfina, respectivamente) es ligeramente superior al encontrado en el caso del receptor de pez cebra.

Dada la gran repercusión que tiene la morfina en la clínica y puesto que los procesos de internalización se han relacionado con los problemas de tolerancia a la misma quisimos determinar la posible existencia de internalización del receptor mu de pez cebra tras un tratamiento con morfina. En la figura 65 se observa que, ni en el caso del receptor de pez cebra, ni en el de rata, se puede apreciar internalización del receptor. Esto está en consonancia con los resultados obtenidos por otros grupos en los que tampoco se observa internalización inducida por morfina mediante microscopia (Keith y cols., 1996; Segredo y cols., 1997; Burford y cols., 1997; Koch y cols., 2001). En los casos en los que se llevaron a cabo estudios de internalización mediante citometría de flujo, que nos permiten obtener una buena cuantificación del proceso, se presentaron valores en torno al $10 \%$ de internalización (Zaki y cols., 
2000; Whistler y cols., 1999; Johnson y cols., 2006), también similares a los encontrados para el receptor zfMOR.

Los resultados obtenidos para el estudio de internalización apuntan a que no hay grandes diferencias entre la capacidad de internalización de los distintos compuestos empleados sin embargo un estudio más completo, que incluyera cinéticas de internalización podría dar más información a este respecto. Por ejemplo se sabe que la fosforilación de la treonina en posición 394 del receptor de rata actúa como un freno de la internalización ya que la isoforma rMOR1B cuyo extremo carboxilo terminal es más corto, careciendo de este residuo, internaliza con mayor facilidad que la isoforma rMOR1 (Zimprich y cols., 1995; Koch y cols., 1998). Así mismo la simple sustitución de dicho residuo en la isoforma rMOR1 por una alanina, también facilita el proceso de internalización (Wolf y cols., 1999). Es interesante apuntar que en el caso del receptor opioide mu de pez cebra ese residuo de treonina no existe ya que zfMOR tiene un extremo carboxilo terminal 11 residuos más corto que el de ratón, rata y humano en los que sí aparece dicho residuo (Figura 83).

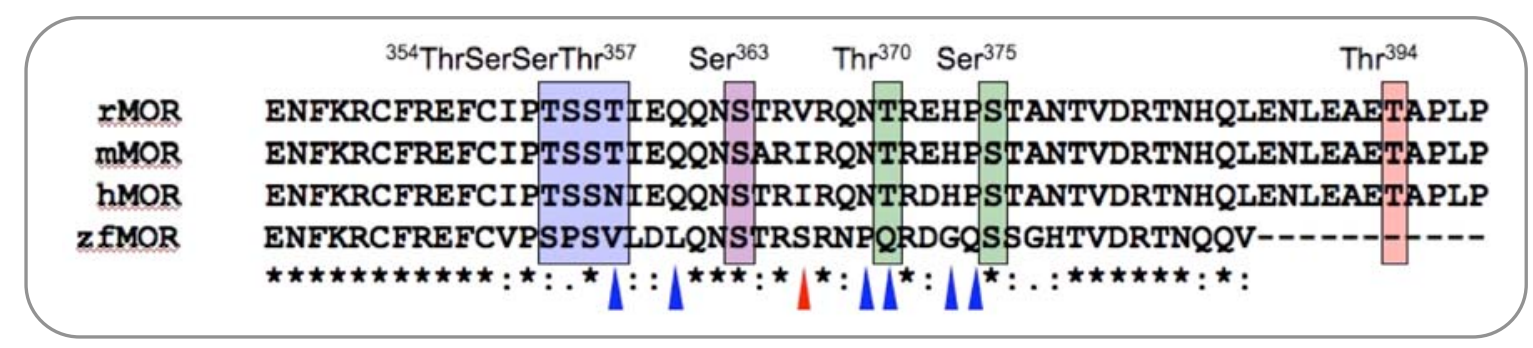

Figura 83: En es figura se muestra una comparación obtenida mediante ClustalW de los extremos carboxilo terminal de los receptores mu de rata (rMOR), ratón (mMOR), humano (hMOR) y pez cebra (zfMOR). Los asteriscos en la parte inferior de las secuencias indican que el residuo en esa posición es el mismo en las 4 secuencias. Los dos puntos indican que hay un cambio de tipo conservativo mientras que un punto indica un cambio semiconservativo. Los triangulos azules señalan cambios en los que se modifica por completo el carácter del aminoácido y con el triángulo rojo se destaca la aparición de una serina en el receptor zfMOR que puede ser susceptible de fosforilación. Los distintos recuadros de colores resaltan residuos de serina o treonina que se han identificado como importantes en la regulación del receptor. 
A pesar de la carencia de este residuo los resultados de internalización obtenidos son semejantes a los encontrados en otras especies, aunque hay que tener en cuenta que se ha podido ver afectada la velocidad de la internalización, parámetro que no hemos determinado. Teniendo en cuenta esto, puede que la fosforilación del residuo 394, en el caso del receptor de rata, en el receptor de pez cebra tenga lugar en otro residuo del extremo carboxilo terminal.

Otros residuos que se consideran importantes para los procesos de internalización son la serina 363, la treonina 370 y la serina 375 (el Kouhen y cols., 2001). La fosforilación de estos residuos ocasiona respuestas contrapuestas. Por un lado existe una fosforilación basal de los residuos serina 363 y treonina 370 lo que provoca una atenuación de la internalización; por otro lado la fosforilación de la serina 375, dependiente de agonista, promueve la internalización. En el caso del receptor zfMOR el residuo de treonina 370 está sustituido por una glutamina; este hecho podría explicar porque observamos una mayor internalización basal en zfMOR en comparación al receptor mu de rata (comparación realizada sobre las fotos de inmunofluorescencia). Además el hecho de que DAMGO induzca la fosforilación, de forma específica, de ese residuo también nos puede ayudar a explicar el nivel de internalización, ligeramente inferior al de mamífero, encontrado para zfMOR. Por último la secuencia ${ }^{354} \mathrm{ThrSerSerThr}{ }^{357}$ también se ha considerado importante para los procesos de internalización, ya que un receptor truncado a partir del residuo 354 posee una internalización constitutiva del receptor; sin embargo si se trunca a partir del residuo 363, este receptor no sufre la internalización constitutiva (Segredo y cols., 1997). En el caso del receptor de pez cebra aparecen dos sustituciones, una semiconservativa y una no conservativa. Este hecho no altera las propiedades de 
internalización del receptor sin embargo sería necesario un estudio más detallado para determinar la importancia de ese dominio en el receptor zfMOR. 
Conclusiones 

Una vez alcanzados los objetivos fundamentales de este trabajo de investigación podemos llegar a las siguientes conclusiones:

Objetivo 1: Determinar la posible existencia de duplicados del receptor opioide mu del pez cebra.

Hasta el momento no existe evidencia de la existencia de un gen duplicado de zfMOR, sin embargo, tendremos que esperar a la finalización de la secuenciación del genoma del pez cebra para descartar completamente esa posibilidad.

Objetivo 2: Conseguir un sistema de expresión estable del receptor zfMOR.

Desde este momento contamos con un sistema de expresión del receptor zfMOR, así como con receptores marcados y mutantes, para el estudio de la actividad de los mismos.

Objetivo 3: Probar la actividad biológica del receptor zfMOR

3a: Analizar si el receptor exhibe sitios de unión estereoespecíficos y saturables para agentes opioides.

El receptor zAMOR une agentes opioides de forma espereoespecífica y saturable y dicha unión es desplazada por la naloxona, lo que permite definirlo, sin lugar a dudas, como un receptor de tipo opioide. 
3b: Estudiar la capacidad de unión de distintos agentes opioides al receptor zfMOR.

El receptor zfMOR presenta una farmacología muy similar a la encontrada en los receptores opioides de otros organismos, sin embargo, pequeñas diferencias en determinados agentes lo hacen muy interesante para el estudio de la unión del agente al receptor y el desarrollo de nuevos fármacos.

3c: Estudiar los mecanismos de activación del receptor zfMOR.

El receptor zfMOR es completamente funcional ya que es capaz de activar las rutas de señalización intracelular, con un patrón casi indistinguible de los receptores opioides de mamíferos.

3d: Estudiar la capacidad de internalización del receptor zfMOR por distintos agentes opioides.

El receptor zfMOR sufre internalización tras la activación por parte de un agente de forma semejante a como ocurre en otros receptores opioides.

Estas conclusiones nos permiten afirmar que nuestra hipótesis de trabajo puede ser válida aunque es necesario continuar con esta investigación para poder relacionar nuestros resultados con los temas de dolor, tolerancia, dependencia y diseño de nuevos fármacos. 
Bibliografía 

Abbadie C., Pan Y.X., Pasternak G.W. (2000). Differential distribution in rat brain of mu opioid receptor carboxy terminal splice variants MOR-1C-like and MOR-1-like immunoreactivity: evidence for region-specific processing. J. Comp. Neurol. 419(2): 244-256.

Abbadie C., Pan Y.X., Pasternak G.W. (2004). Immunohistochemical study of the expression of exon11-containing mu opioid receptor variants in mouse brain. Neuroscience. 127(2): 419-430.

Abood M.E, Lee N.M, Loh H.H. (1987). Modification of opioid agonist binding by pertussis toxin. Brain. Res. 417(1): 70-74.

Alt A., Mansour A., Akil H., Medzihradsky F., Traynor J.R., Woods J.H. (1998). Stimulation of guanosine-5'-O-(3-[ $\left[{ }^{35} \mathrm{~S}\right]$ thio)triphosphate binding by endogenous opioids acting at a cloned mu receptor. J. Pharmacol. Exp. Ther. 286(1): 282-288.

Alvar F.A., Rodriguez-Martin I., Gonzalez-Nuñez V., de Velasco E.M., Gonzalez Sarmiento R., Rodríguez R.E. (2006). New kappa opioid receptor from zebrafish Danio rerio. Neurosci. Lett. 405(12): 94-99.

Anichtchik O.V., Kaslin J., Peitsaro N., Sheinin M., Panula P. (2004) Neurochemical and behavioral changes in zebrafish Danio rerio after systemic administration of 6-hydroxydopamine and 1-methyl-4-phenyl-1,2,3,6-tetrahydropyridine. J. Neurochem. 88: 443-453.

Arden J.R., Segredo V. Zaijie W., Lameh J. Sadeé W. (1995). Phosphorilation and Agonist-Specific Intracellular Trafficking o fan Epitope-Tagged $\mu$-Opioid Receptor Expressed in HEK 293 Cells. Journal of Neurochemistry. 65(4): 1636-1645.

Arnis S., Fahmy K., Hofmann K.P., Sakmar T.P. (1994). A conserved carboxylic acid group mediates light-dependent proton uptake and signaling by rhodopsin. J. Biol. Chem. 269(39): 2387923881.

Avidor-Reiss T., Nevo I., Saya D., Bayewitch, M., Vogel, Z. (1997). Opiate-induced adenylyl cyclase superactivation is isozyme-specific. J. Biol. Chem. 272: 50404-5047.

Ballesteros J., Kitanovic S., Guarnieri F., Davies P., Fromme B.J., Konvicka K., Chi L., Millar R.P., Davidson J.S., Weinstein H., Sealfon S.C. (1998). Functional microdomains in G-proteincoupled receptors. The conserved arginine-cage motif in the gonadotropin-releasing hormone receptor. J. Biol. Chem. 273(17): 10445-10453.

Ballesteros J., Weinstein H. (1995). Integrated methods for the construction of three-dimensional models of structure-function relations in G protein-coupled receptors. Meth. Neurosci. 25: 366-428. 
Barrallo A., Gonzalez-Sarmiento R., Alvar F., Rodríguez R.E. (2000). ZFOR2, a new opioid receptor-like gene from the teleost zebrafish. Brain Res. Mol. Brain Res. 48(1-2): 1-6.

Barrallo A., Gonzalez-Sarmiento R., Porteros A., García-Isidoro M., Rodríguez, R.E. (1998a). Cloning, molecular characterization, and distribution of a gene homologous to delta opioid receptor from zebrafish (Danio rerio). Biochem. Biophys. Res. Commun. 245(2): 544-548.

Barrallo A., Malvar F.G., González R., Rodríguez R.E., Traynor J.R. (1998b). Cloning and Blake A.D., Bot G., Freeman J.C., Reisine T. (1997). Differential opioid agonist regulation of the mouse mu opioid receptor. J. Biol. Chem. 272(2):782-790.

Basbaum A.I., Fields H.L. (1984). Endogenous pain control systems: brainstem spinal pathways and endorphin circuitry. Annu. Re.v Neurosci. 7: 309-38. Review.

Befort K., Tabbara L., Bausch S., Chavkin C., Evans C., Kieffer B. (1996). The conserved aspartate residue in the third putative transmembrane domain of the delta-opioid receptor is not the anionic counterpart for cationic opiate binding but is a constituent of the receptor binding site. Mol Pharmacol. 49(2): 216-223.

Besson J.M. (1999). The neurobiology of pain. The Lancet 353: 1610-1615.

Biotechniques. 23(4): 570-574.

Blake A.D., Bot G., Freeman J.C., Reisine T. (1997). Differential opioid agonist regulation of the mouse mu opioid receptor. J Biol Chem. 272(2): 782-790.

Bolan E.A., Pan Y.X., Pasternak G.W. (2004). Functional analysis of MOR-1 splice variants of the mouse mu opioid receptor gene Oprm. Synapse. 51(1):11-18.

Bolan E.A., Schuller A., Yang K., Brown G.P., Pintar J.E., Pasternak G.W. (1997). ${ }^{3}$ H-morphine6-glucuronide binding in MOR1 knockout mice. Society for Neuroscience 27th Annual Meeting. New Orleans, USA.

Bolay H., Mskowitz M.A. (2002). Mechanisms of pain modulation in chronic syndromes. Neurology 59(Suppl 2):S2-7.

Bonner G., Meng F., Akil H. (2000). Selectivity of mu-opioid receptor determined by interfacial residues near third extracellular loop. Eur. J. Pharmacol. 403(1-2): 37-44. 
Borgland S.L., Connor M., Osborne P.B., Furness J.B., Christie M.J. (2003). Opioid agonists have different efficacy profiles for $\mathrm{g}$ protein activation, rapid desensitization, and endocytosis of mu-opioid receptors. J. Biol. Chem. 278(21): 18776-18784.

Bradbury A.F., Smith D.G., Snell C.R., Birdsall N.J.M., Hulme E.C. (1976). C fragment of lipotropin has high affinity for brain opiate receptors. Nature 260: 295-306.

Brownstein M.J. (1993). A brief history of opiates, opioid peptides and opioid receptors. Proc. Natl. Acad. Sci.USA. 89: 5391-5393.

Burford N.T., Tolbert L.M., Sadee W. (1998). Specific G protein activation and mu-opioid receptor internalization caused by morphine, DAMGO and endomorphin I. Eur. J. Pharmacol. 342(1): 123-126.

Cadet P. (2004). Mu opiate receptor subtypes. Med Sci Monit. 10(6):MS28- 32.

Capeyrou R., Riond J., Corbani M., Lepage J.F., Bertin B., Emorine L.J. (1997). Agonist-induced signaling and trafficking of the m-opioid receptor: role of serine and threonine residues in the third cytoplasmic loop and C-terminal domain. FEBS. letters. 415: 200-205.

Caudle R.M., Mannes A.J., Iadarola M.J. (1997). GR89,696 is a kappa-2 opioid receptor agonist and a kappa-1 opioid receptor antagonist in the guinea pig hippocampus. .J Pharmacol. Exp. Ther. ;283(3):1342-1349.

Chaipatikul V., Loh H.H., Law P.Y. (2003). Ligand-selective activation of mu-opioid receptor: demonstrated with deletion and single amino acid mutations of third intracellular loop domain. $J$. Pharmacol. Exp. Ther. 305(3): 909-918.

Chakrabarti S., Law, P.Y., Loh, H.H. (1998). Distinct differences between morphine and [D-Ala2, N-MePhe4, Gly-ol5]-enkephalin $\mu$ opioid receptor complexes demonstrated by cyclic AMP-dependent protein kinase phosphorylation. J. Neurochem. 71: 231-239.

Chan J.S.C., Chiu, T.T., Wong, Y.H. (1995). Activation of type II adenylyl cyclase by the cloned $\mu$ opioid receptor: coupling to multiple G proteins. J. Neurochem. 65: 2682-2689.

Chang A.C., Cochet M., Cohen S.N. (1980). Structural organization of human genomic DNA encoding the pro-opiomelanocortin peptide. Proc. Natl. Acad. Sci. U S A. 77(8): 4890-4894.

Chao C.C., Hu S., Shark K.B. Gekker G., Peterson P.K., (1997). Activation of Mu opioid receptors inhibits microglial cell chemotaxis. J. Pharmacol. Exp. Ther. 281: 998-1004. 
Chavkin C., McLaughlin J.P., Celver J.P. (2001). Regulation of opioid receptor function by chronic agonist exposure: constitutive activity and desensitization. Mol. Pharmacol. 60(1): 20-25.

Chen C., Shahabi V., Xu W., Liu-Chen L.Y. (1998). Palmitoylation of the rat mu opioid receptor. FEBS Lett.441(1):148-52.

Chen Y., Mestek A., Liu J., Hurley J.A., Yu L. (1993). Molecular cloning and Functional Expression of a $\mu$-Opioid Receptor from Rat Brain. Molecular Pharmacology. 44: 8-12.

Chen Y., Yu, L. (1994). Differential regulation by cAMP dependent protein kinase and protein kinase $\mathrm{C}$ of the $\mu$ opioid receptor coupling to a $\mathrm{G}$ protein activated $\mathrm{K}^{+}$channel. J. Biol. Chem. 269: 78397842 .

Cheng Y.C., Prusoff W.H. (1973). Relationship between the inhibition constant $\left(\mathrm{K}_{\mathrm{I}}\right)$ and the concentration of inhibitor which causes 50 per cent inhibition $\left(\mathrm{I}_{50}\right)$ of an enzymatic reaction. Biochem. Pharmacol. 22: 3099-3108.

Chomczynski P., Sacchi N. (1987). Single step method of RNA isolation by acid guanidium thiocyanate-phenol-chlorophorm extraction. Anal. Biochem. 162: 156-159.

Civelli O., Douglass J., Goldstein A,. Herbert E. (1985). Sequence and expression of the rat prodynorphin gene. Proc. Natl. Acad. Sci. U S A. 82(12): 4291-4295.

Clark J.M. (1988). Novel non-templated nucleotide addition reactions catalyzed by procaryotic and eukaryotic DNA polimerases. Nucl. Acids Res. 16,9677.

Clark M.J., Carter B.D., Medzihradsky F. (1988). Selectivity of ligand binding to opioid receptors in brain membranes from the rat, monkey and guinea pig. Eur. J. Pharmacol. 148(3): 343-351.

Clark, J.A., Liu, L., Price, M., Hersh, B., Edelson, M., Pasternak, G.W. (1989). к opiate receptor multiplicity: evidence for two U50488-sensitive $\kappa_{1}$ subtypes and a novel $\kappa_{3}$ subtype. J. Pharmacol. Exp. Ther. 251: 461-468.

Comb M, Seeburg P.H., Adelman J., Eiden L., Herbert E. (1982). Primary structure of the human Met- and Leu-enkephalin precursor and its mRNA. Nature. 295(5851): 663-666.

Cotecchia S., Exum S., Caron M.G., Lefkowitz R.J. (1990). Regions of the alpha 1-adrenergic receptor involved in coupling to phosphatidylinositol hydrolysis and enhanced sensitivity of biological function. Proc. Natl. Acad. Sci. USA. 87(8): 2896-2900. 
Crick F.H.C. (1966). Codon-Anticodon pairing: The wobble hypothesis. J. Mol. Biol. 19: 548-555.

Cvejic S., Trapaidze N., Cyr C., Devi L.A. (1996). Thr353, located within the COOH-terminal tail of the delta opiate receptor, is involved in receptor down-regulation. J. Biol. Chem. 271(8): 4073-4076.

Darland T., Dowling J.E. (2001). Behavioral screening for cocaine sensitivity in mutagenized zebrafish. Proc. Natl. Acad. Sci. USA. 98(20): 11691-11696.

Darlison M.G., Greten F.R., Harvey R.J., Kreienkamp H.J., Stühmer T., Zwiers H., Lederis K., Richter D. (1997). Opioid receptors from a lower vertebrate (Catostomus commersoni): sequence, pharmacology, coupling to a G-protein-gated inward-rectifying potassium channel (GIRK1), and evolution. Proc. Natl. Acad. Sci. USA. 94(15):8214-8219.

de Lanerolle N.C., Williamson A., Meredith C., Kim J.H., Tabuteau H., Spencer D.D., Brines M.L. (1997). Dynorphin and the kappa 1 ligand $\left[{ }^{3} \mathrm{H}\right] \mathrm{U} 69,593$ binding in the human epileptogenic hippocampus. Epilepsy Res. 28(3): 189-205.

Décaillot F.M., Befort K., Filliol D., Yue S., Walker P., Kieffer B.L. (2003). Opioid receptor random mutagenesis reveals a mechanism for $\mathrm{G}$ protein-coupled receptor activation. Nat. Struct. Biol. 10(8): 629-636.

Dietrich G., Gaibelet G., Capeyrou R., Butour J.L., Pontet F., Emorine L.J. (1998). Implication of the first and third extracellular loops of the mu-opioid receptor in the formation of the ligand binding site: a study using chimeric mu-opioid/angiotensin receptors. J. Neurochem. 70(5): 2106-2111.

Dlugos C.A., Rabin R.A. (2003). Etanol effects of three strains of zebrafish: model system for genetic investigations. Pharmacol. Biochem. Behav. 74(2): 471-480.

Dolhman H.G., Thorner J., Caron M.G., Lefkowitz R.J. (1991). Model systems for the study of seven-transmembrane-segment receptors. Annu. Rev. Biochem. 60: 653-688.

Dooley, K., Zon, L.I. (2000). Zebrafish: a model system for the study of human disease. Current Opinion in Genetics \& Development 10:252-256.

Driever W., Solnica-Krezel L., Shier A.F., Neuhauss S.C.F., Malicki J., Stemple D.L., Stainier D.Y.R., Zwartkruis F., Abdelilah S., Rangini Z., Belak J., Boggs C. (1996). A genetic screen for mutations affecting embryogenesis in zebrafish. Development 123: 37-46.

Driever W., Stemple D., Schier A., Solnica-Krezel L. (1994). Zebrafish: genetics tools for studying vertebrate development. Trends Genet. 10: 152-159. 
Egan C., Herrick-Davis K., Teitler M. (1998). Creation of a constitutively activated state of the 5HT2A receptor by site-directed mutagenesis: revelation of inverse agonist activity of antagonists. Ann. NY. Acad. Sci. 861: 136-139.

Eisenstein T.K., Hilburger M.E., (1998). Opioid modulation of inmune responses: effects on phagocyte and lymphoid cell populations. J. Neuroinminol. 83: 36-44.

el Kouhen R., Burd A.L., Erickson-Herbrandson L.J., Chang C.Y., Law P.Y., Loh H.H. (2001). Phosphorylation of Ser363, Thr370, and Ser375 residues within the carboxyl tail differentially regulates mu-opioid receptor internalization. J. Biol. Chem. 276(16): 12774-12780.

Escohotado A. (1992). Historia general de las drogas. 2 ed. Alianza Editorial. Madrid.

Evans C.J., Keith D.E., Morrison H., Magendzo K., Edwards R.H. (1992). Cloning of a d opioid receptor by functional expression. Science. 258: 1952-1955.

Fields H.L., Heinricher M.M., Mason P. (1991). Neurotransmitters in nociceptive modulatory circuits. Annu. Rev. Neurosci. 14: 219-245.

Fisher C.L., Pei G.K. (1997). Modification of a PCR-based site-directed mutagenesis method.

Fishman M.C. (2001). Zebrafish - the canonical vertebrate. Science 294: 1290-1291.

Flórez J. (1992). Fármacos analgésicos opiáceos. En J. Flórez (Ed.), Farmacología Humana. MassonSalvat. Barcelona.

Fowler C.B., Pogozheva I.D., LeVine H. 3rd, Mosberg H.I. (2004). Refinement of a homology model of the mu-opioid receptor using distance constraints from intrinsic and engineered zinc-binding sites. Biochemistry. 43(27): 8700-8710.

Fraser C.M., Wang C.D., Robinson D.A., Gocayne J.D., Venter J.C. (1989). Site-directed mutagenesis of $\mathrm{m} 1$ muscarinic acetylcholine receptors: conserved aspartic acids play important roles in receptor function. Mol. Pharmacol. 36(6): 840-847.

Fukuda K., Kato S., Mori K. (1995a). Location of regions of the opioid receptor involved in selective agonist binding. J. Biol. Chem. 270(12): 6702-6709.

Fukuda K., Kato S., Mori K., Nishi M., Takeshima H. (1993). Primary structures and expression from cDNAs of rat opioid receptor delta- and mu-subtypes. FEBS lett. 327(3): 311-314 
Fukuda K., Terasako K., Kato S., Mori K. (1995b). Identification of the amino acid residues involved in selective agonist binding in the first extracellular loop of the delta- and mu-opioid receptors. FEBS. Lett. 373(2): 177-181.

Gerlai R., Lahav M., Guo S., Rosenthal A. (2000). Drinks like a fish: zebrafish (Danio rerio) as a behavior genetic model to study alcohol effects. Pharmacol. Biochem. Behav. 67(4): 773-782.

Gether U. (2000). Uncovering molecular mechanisms involved in activation of G protein-coupled receptors. Endocr. Rev. 21(1): 90-113.

Gharagozlou P., Demirci H., David Clark J., Lameh J. (2003). Activity of opioid ligands in cells expressing cloned mu opioid receptors. BMC. Pharmacol. 3:1.

Goldsmith P. (2004). Zebrafish as a pharmacological tool: the how, why and when. Curr. Op. in Pharmacol. 4: 504-512.

Goldstein A., Fischli W., Lowery L.I., Hunkapiller M., Hood L. (1981). Porcine pituitary dynorphin: complete aminoacid sequence of the biologically active heptadecapeptide. Proc. Natl. Acad. Sci. USA 78: 7219-7223.

Goldstein A., Lowney L.I., Pal B.K. (1971). Stereoespecific and nonspecific interactions of the morphine congener levorphanol in subcellular fractions of mouse brain. Proc. Natl. Acad. Sci. USA 68: $1742-1747$.

González-Darder J.M. (2000). Modelos animales de dolor y aspectos éticos de la experimentación animal. Rev. Soc. Esp. Dolor 7: 313-318.

Gonzalez-Nuñez V., Gonzalez-Sarmiento R., Rodríguez R.E. (2003a). Characterization of zebrafish proenkephalin reveals novel opioid sequences. Molecular Brain Research. 114: 31-39.

Gonzalez-Nuñez V., Gonzalez-Sarmiento R., Rodríguez R.E. (2003b). Cloning and characterization of a fulllength pronociceptin in zebrafish: evidence of the existence of two different nociceptin sequences in the same precursor. Biochimica et Biophysica Acta - Gene Structure and Expresión. 1629: 114-118.

Gonzalez-Nuñez V., Gonzalez-Sarmiento R., Rodríguez R.E. (2003c). Identification of two proopiomelanocortin genes in zebrafish Danio rerio. Molecular Brain Research. 120: 1-8.

Gudermann T., Schöneberg T., Schultz G. (1997). Functional and structural complexity of signal transduction via G-protein-coupled receptors. Annu. Rev. Neurosci. 20: 399-427. 
Guo, S. (2004). Linking genes to brain, behaviour and neurological diseases: what can we learn from zebrafish?. Genes, Brain and Behavior 3: 63-74.

Haffter, P., Granato, M., Brand, M., Mullins, M.C., Hammerschmidt, M., Kane, D.A., Odenthal, J., van Eeden, F.J., Jiang, Y.J., Heisenberg, C.P., Kelsh, R.N., Furutani-Seiki, M., Vogelsang, E., Beuchle, D., Schach, U., Fabian, C., Nusslein-Volhard, C., (1996). The identification of genes with unique and essential functions in the development of the zebrafish, Danio rerio. Development 123: 136.

Hawkins K.N., Knapp R.J., Lui G.K., Gulya K., Kazmierski W., Wan Y.P., Pelton J.T., Hruby V.J., Yamamura H.I. (1989). [3H]-[H-D-Phe-Cys-Tyr-D-Trp-Orn-Thr-Pen-Thr-NH2] ([3H]CTOP), a potent and highly selective peptide for mu opioid receptors in rat brain. J. Pharmacol. Exp. Ther. 248(1): 73-80.

Henry D.J., Grandy D.K., Lester H.E., Davidson N., Chavkin C. (1995). א opioid receptors couple to inwardly rectifying potassium channels when coexpressed by Xenopus oocytes. Mol. Pharmacol. 47: 551-557.

Hibert M.F., Trumpp-Kallmeyer S., Bruinvels A., Hoflack J. (1991). Three-dimensional models of neurotransmitter G-binding protein-coupled receptors. Mol. Pharmacol. 40(1): 8-15.

Hibert M.F., Trumpp-Kallmeyer S., Hoflack J., Bruinvels A. (1993). This is not a G proteincoupled receptor. Trends. Pharmacol. Sci. 14(1):7-12.

Hjorth S.A., Thirstrup K., Grandy D.K., Schwartz T.W. (1995). Analysis of selective binding epitopes for the kappa-opioid receptor antagonist nor-binaltorphimine. Mol. Pharmacol. 47(6): 10891094.

Horikawa S., Takai T., Toyosato M., Takahashi H., Noda M., Kakidani H., Kubo T., Hirose T., Inayama S., Hayashida H. (1983). Isolation and structural organization of the human reproenkephalin B gene. Nature. 306(5943): 611-614.

Horne-Badovinac S., Lin D., Waldron S., Schwarz M., Mbamalu G., Pawson T., Jan Y., Stainier D.Y. Abdelilah-Seyfried S. (2001) Positional cloning of Herat and soul reveals multiple roles for PKC lambda in zebrafish organogenesis. Curr. Biol. 11(19): 1492-1502.

Hughes J. (1975). Isolation of an endogenous compound from the brain with pharmacological properties similar to morphine. Brain Res. 88: 295-308. 
Hughes J., Smith T., Kosterlitz H.W., Fothergill L.A., Morgan, B.A., Morris, H.R. (1975). Identification of two related pentapeptides from the brain with potent opiate agonist activity. Nature 258: 577-579.

Ingham, P.W. (1997). Zebrafish genetics and its implications for understanding vertebrate development. Hum. Mol. Genet. 6: 1755-1760.

Ingram S.L., Vaughan C.W., Bagley E.E., Connor M., Christie M.J. (1998). Enhanced opioid efficacy in opioid dependence is caused by an altered signal transduction pathway. J. Neurosci. 18(24): 10269-10276.

Jaffe J.M., Martin W.R. (1990). Opioid analgesics and antagonists. Pharmacological Basis of Therapeutics. (Gilman A., Rall J., Nies A. and Taylor P., Eds), pp. 485-573. New York. Pergamon Press.

Ji I., Ji T.H. (1991). Asp383 in the second transmembrane domain of the lutropin receptor is important for high affinity hormone binding and cAMP production. J. Biol. Chem. 266(23): 14953-14957.

Johnson E.A., Oldfield S., Braksator E., Gonzalez-Cuello A., Couch D., Hall K.J., Mundell S.J., Bailey C.P., Kelly E., Henderson G. (2006). Agonist-selective mechanisms of mu-opioid receptor desensitization in human embryonic kidney 293 cells. Mol. Pharmacol. 70(2): 676-685.

Johnson P.H., Grosmann, L.I. (1977). Electrophoresis of DNA in agarose gels. Optimizing separation of conformational isomers of double and single stranded DNAs. Biochem. 16(19): 4217 4225 .

Kakidani H., Furutani Y., Takahashi H., Noda M., Morimoto Y., Hirose T., Asai M., Inayama S., Nakanishi S., Numa S. (1982). Cloning and sequence analysis of cDNA for porcine beta-neoendorphin/dynorphin precursor. Nature. 298(5871): 245-249.

Kangawa K., Minamino N., Chino N., Sakakibara S., Matsuo H. (1981) The complete amino acid sequence of alpha-neo-endorphin. Biochem Biophys Res Commun. 99(3): 871-878.

Kaufman D.L., Keith D.E. Jr, Anton B., Tian J., Magendzo K., Newman D., Tran T.H., Lee D.S., Wen C., Xia Y.R., Lusis A.J, Evans C.J. (1995). Characterization of the murine mu opioid receptor gene. J. Biol. Chem. 270(26):15877-15883.

Keith D.E., Murray S.R., Zaki P.A., Chu P.C., Lissin D.V., Kang L., Evans C.J., von Zastrow M. (1996). Morphine activates opioid receptors without causing their rapid internalization. J. Biol. Chem. 271(32): 19021-190214. 
Kelly E., Bailey C.P., Henderson G. (2008). Agonist-selective mechanisms of GPCR desensitization. Br. J. Pharmacol. 153 Suppl 1: S379-388.

Kieffer B.L., Befort K., Gaveriaux-Ruff C., Hirth C.G. (1992). The $\delta$ opioid receptor. Isolation of a cDNA by expression cloning and pharmacological characterization. Proc. Natl. Acad. Sci. USA. 89: 12048-12052

Knapp R.J., Malatynska E., Fang L., Li X., Babin E., Nguyen M., Santoro G., Varga E.V., Hruby V.J., Roeske W.R., Yamamura H.I. (1994) Identification of a human $\delta$ opioid receptor: cloning and expression. Life Sci. 54: 463-469.

Koch T., Kroslak T., Mayer P., Raulf E., Höllt V. (1997). Site mutation in the rat mu-opioid receptor demonstrates the involvement of calcium/calmodulin-dependent protein kinase II in agonist-mediated desensitization. J Neurochem. Oct;69(4):1767-70.

Koch T., Höllt V. (2008). Role of receptor internalization in opioid tolerance and dependence. Pharmacol. Ther. 117(2): 199-206.

Koch T., Schulz S., Pfeiffer M., Klutzny M., Schröder H., Kahl E., Höllt V. (2001). C-terminal splice variants of the mouse mu-opioid receptor differ in morphine-induced internalization and receptor resensitization. J. Biol. Chem. 276(33): 31408-31414.

Koch T., Schulz S., Schröder H., Wolf R., Raulf E., Höllt V. (1998). Carboxyl-terminal splicing of the rat mu opioid receptor modulates agonist-mediated internalization and receptor resensitization. $J$. Biol. Chem. 273(22): 13652-13657.

Kong H., Raynor K., Yasuda K., Bell G.I., Reisine T. (1993b). Mutation of an aspartate at residue 89 in somatostatin receptor subtype 2 prevents $\mathrm{Na}+$ regulation of agonist binding but does not alter receptor-G protein association. Mol. Pharmacol. 44(2): 380-384.

Kong H., Raynor K., Yasuda K., Moe S.T., Portoghese P.S., Bell G.I., Reisine T. (1993a). A single residue, aspartic acid 95, in the delta opioid receptor specifies selective high affinity agonist binding. $J$. Biol. Chem. 268(31): 23055-23058.

Kosterlitz H.W., Waterfield A.A. (1975). In vitro models in the study of structure-activity relationships of narcotic analgesics. Annu. Rev. Pharmacol. Toxicol. 15: 29-47.

Kuhar M.J., Pert C.B., Snyder S.H. (1973). Regional distribution of opiate receptor binding in monkey and human brain. Nature 245: 447-451. 
Kurose H., Katada T., Amano T., Ui M. (1983). Specific uncoupling by islet-activating protein, pertussis toxin, of negative signal transduction via alpha-adrenergic, cholinergic, and opiate receptors in neuroblastoma x glioma hybrid cells. J. Biol. Chem. 258(8): 4870-4875.

Labarre M., Butterworth J., St-Onge S., Payza K., Schmidhammer H., Salvadori S., Balboni G., Guerrini R., Bryant S.D., Lazarus L.H. (2000). Inverse agonism by Dmt-Tic analogues and HS 378, a naltrindole analogue. Eur. J. Pharmacol. 406(1): R1-3.

Law P.Y., Hom D.S., Loh H.H. (1982). Loss of opiate receptor activity in neuroblastoma X glioma NG108-15 hybrid cells after chronic opiate treatment. A multiple-step process. Mol. Pharmacol. 22(1): $1-4$.

Law P.Y., Hom D.S., Loh H.H. (1983). Opiate receptor down-regulation and desensitization in neuroblastoma X glioma NG108-15 hybrid cells are two separate cellular adaptation processes. Mol. Pharmacol. 24(3): 413-24.

Law P.Y., Hom D.S., Loh H.H. (1984). Down-regulation of opiate receptor in neuroblastoma X glioma NG108-15 hybrid cells. Chloroquine promotes accumulation of tritiated enkephalin in the lysosomes. J. Biol. Chem. 259(7): 4096-4104.

Law P.Y., Wong Y.H., Loh H.H. (1999). Mutational analysis of the structure and function of opioid receptors. Biopolymers. 51(6): 440-455.

Law P.Y., Wong Y.H., Loh H.H. (2000). Molecular mechanisms and regulation of the opioid receptor signalling. Annu. Rev. Pharmacol. Toxicol. 40: 389-430.

Lee K.O., Akil H., Woods J.H., Traynor J.R. (1999). Differential binding properties of oripavines at cloned mu- and delta-opioid receptors. Eur. J. Pharmacol. 13;378(3): 323-330.

Legon S., Glover D.M., Hughes J., Lowry P.J., Rigby P.W., Watson C.J. (1982). The structure and expression of the preproenkephalin gene. Nucleic Acids Res. 10(24): 7905-7918.

Leon-Olea M., Miller-Perez C., Cruz R., Antón B., Vega R., Soto E., (2001). Immunohistochemical localization and electrophysiological action of nociceptin/orphanin-FQ in the snail (Helix aspersa) neurons. Neurosci Lett. 316: 141-144.

Li J., Chen C., Huang P., Liu-Chen L.Y. (2001). Inverse agonist up-regulates the constitutively active D3.49(164)Q mutant of the rat mu-opioid receptor by stabilizing the structure and blocking constitutive internalization and down-regulation. Mol. Pharmacol. 60(5): 1064-1075. 
Lord J.A.H., Waterfield A.A., Hughes J., Kosterlitz H.W. (1977). Endogenous opioid peptides: multiple agonists and receptors. Nature 267: 495-499.

Lowry O.H., Rosebrough N.J., Farr A.L., Randall R.J. (1951). Protein measurement with the folin phenol reagent. J. Biol. Chem. 193: 265-275.

Mansour A., Fox, C.A., Akil H., Watson S.J. (1995a). Opioid-receptor mRNA expression in the rat CNS: anatomical and functional implications. Trends Neurosci. 18: 22-29.

Mansour A., Hoversten M.T., Taylor L.P., Watson S.J. Akil H. (1995b). The cloned $\mu, \delta$ and $\kappa$ receptors and their endogenous ligands: Evidence for two opioid peptide recognition cores. Brain Res. 700: 89-98.

Mansour A., Taylor L.P., Fine J.L., Thompson R.C., Hoversten M.T., Mosberg H.I., Watson S.J., Akil H. (1997). Key residues defining the mu-opioid receptor binding pocket: a site-directed mutagenesis study. J. Neurochem. 68(1): 344-353.

Martin N.A., Ruckle M.B., VanHoof S.L., Prather P.L. (2002). Agonist, antagonist, and inverse agonist characteristics of TIPP (H-Tyr-Tic-Phe-Phe-OH), a selective delta-opioid receptor ligand. $J$. Pharmacol. Exp. Ther. 301(2): 661-671.

Martin W.R., Eades C.G., Thompson J.A., Huppler R.E., Gilbert P.E. (1976). The effects of morphine- and nalorphine-like drugs in the nondependent and morphine-dependent chronic spinal dog. J. Pharmacol. Exp. Ther. 197: 517-532.

Matthes H.W.D., Maldonado, R., Simonin, F., Valverde, O., Slowe, S., Kitchen, I., Befort, K., Dierich, A., LeMeur, M., Dollé, P., Tzavara, E., Hanoune, J., Roques, B.P., Kieffer, B.L. (1996). Loss of morphine-induced analgesia, reward effect and withdrawal symptoms in mice lacking the $\mathrm{m}$ opioid receptor gene. Nature. 383: 819-823.

Mayer, P., Schulzeck, S., Kraus, J., Zimprich, A., Höllt, V. (1996). Promoter region and alternatively spliced exons of the rat m-opioid receptor gene. J. Neurochem. 66: 2272-2278.

McCarthy L., Wetzel M., Sliker J.K., Eisenstein T.K., Rogers T.,J (2001). Opioids, opioid receptors, and immune response. Drug and Alcohol Dependence. 62: 111-123.

Meng F., Hoversten M.T., Thompson R.C., Taylor L., Watson S.J., Akil H. (1995). A chimeric study of the molecular basis of affinity and selectivity of the kappa and the delta opioid receptors. Potential role of extracellular domains. J. Biol. Chem. 270(21): 12730-12736. 
Meng F., Wei Q., Hoversten M.T., Taylor L.P., Akil H. (2000). Switching agonist/antagonist properties of opiate alkaloids at the delta opioid receptor using mutations based on the structure of the orphanin FQ receptor. J. Biol. Chem. 275(29): 21939-21945.

Mestek A., Hurley J.H., Bye L.S., Campbell A.D., Chen Y., Tian M., Liu J., Schulman H., Yu

L.(1995). The human mu opioid receptor: modulation of functional desensitization by calcium/calmodulin-dependent protein kinase and protein kinase C. J Neurosci. 15(3 Pt 2):2396-406.

Metzger T.G., Ferguson D.M. (1995). On the role of extracellular loops of opioid receptors in conferring ligand selectivity. FEBS. Lett. 375(1-2):1-4.

Meunier J.C., Mollereau C., Toll L., Suaudeau C., Moisand C., Alvinerie P., Butour J.L., Guillemot J.C., Ferrara P., Monsarrat B., Mazarguil H., Vassart G., Parmentier M., Costentin J. (1995). Isolation and structure of the endogenous agonist of opioid receptor-like ORL1 receptor. Nature 377: 532-535.

Min B.H., Augustin, L.B., Felsheim, R.F., Fuchs, J.A., Loh, H.H. (1994). Genomic structure and analysis of promoter sequence of a mouse $\mu$ opioid receptor gene. Proc. Natl. Acad. Sci. USA. 91: 9081-9085.

Minami M., Nakagawa T., Seki T., Onogi T., Aoki Y., Katao Y., Katsumata S., Satoh M. (1996). A single residue, Lys108, of the delta-opioid receptor prevents the mu-opioid-selective ligand [DAla2,N-MePhe4,Gly-o15]enkephalin from binding to the delta-opioid receptor. Mol. Pharmacol. 50(5): 1413-1422.

Minami M., Onogi T., Nakagawa T., Katao Y., Aoki Y., Katsumata S., Satoh M. (1995). DAMGO, a mu-opioid receptor selective ligand, distinguishes between mu-and kappa-opioid receptors at a different region from that for the distinction between mu- and delta-opioid receptors. FEBS. Lett. 364(1): 23-27.

Mollereau C., Parmentier M., Mailleux P., Butour J.L., Moisand C., Chalon P., Caput D., Vassart G., Meunier J.C. (1994). ORL1, a novel member of the opioid receptor family. Cloning, functional expression and localization. FEBS Lett. 341: 33-38.

Nakanishi S., Inoue A., Kita T., Nakamura M., Chang A.C., Cohen S.N., Numa S. (1979).

Nucleotide sequence of cloned cDNA for bovine corticotropin-beta-lipotropin precursor. Nature.

278(5703): 423-427. 
Newman L.C., Sands S.S., Wallace D.R., Stevens C.W. (2002). Characterization of mu, kappa, and delta opioid binding in amphibian whole brain tissue homogenates. J. Pharmacol. Exp. Ther. 301(1): 364-370.

Newton C.R., Graham A. (1994). In: PCR, BIOS Scientific Publishers, Ltd., Oxford, UK, 13.

Nishi M., Takeshima H., Fukuda K., Kato S., Mori K. (1993). cDNA cloning and pharmacological characterization of an opioid receptor with high affinities for kappa-subtype-selective ligands. FEBS lett. 330(1): 77-80.

Nishi M., Takeshima H., Mori M., Nakagawara K., Takeuchi T. (1994). Structure and chromosomal mapping of genes for the mouse kappa-opioid receptor and an opioid receptor analog (MOR-C). Biochem. Biophys. Res.Commun. 205: 1353-1357.

Noda M., Furutani Y., Takahashi H., Toyosato M., Hirose T., Inayama S., Nakanishi S., Numa S. (1982). Cloning and sequence analysis of cDNA for bovine adrenal preproenkephalin. Nature. 295 : 2002-2006.

Nüslein-Volhard, C., Wieschaus, E. (1980). Mutations affecting segment number and polarity in Drosophila. Nature 287: 795-801.

Nüsslein-Volhard, C. (1994). Of flies and fishes. Science 266: 572-574.

Oldfield S., Braksator E., Rodriguez-Martin I., Bailey C.P., Donaldson L.F., Henderson G., Kelly E. (2008). C-terminal splice variants of the mu-opioid receptor: existence, distribution and functional characteristics. Journal of Neurochemistry. 104(4): 937-945.

Onogi T., Minami M., Katao Y., Nakagawa T., Aoki Y., Toya T., Katsumata S., Satoh M. (1995). DAMGO, a mu-opioid receptor selective agonist, distinguishes between mu- and delta-opioid receptors around their first extracellular loops. FEBS. Lett. 357(1): 93-97.

Onoprishvili I., Andria M.L., Vilim F.S., Hiller J.M., Simon E.J. (1999). The bovine mu-opioid receptor: cloning of cDNA and pharmacological characterization of the receptor expressed in mammalian cells. Brain. Res. Mol. Brain. Res. 73(1-2): 129-137.

Ossipov M.H., Lai J. King T., Vanderah T.W., Malan Jr. T.P., Hruby V.J., Porreca F. (2004). Antinociceptive and nociceptive actions of opioids. J. Neurobiol. 61:126-148. 
Pak Y., Kouvelas, A., Scheideler, M.A., Rasmussen, J., O’Dowd, B.F., George, S.R. (1996).

Agonist-induced functional desensitization of the $\mu$-opioid receptor is mediated by loss of membrane receptors rather than uncoupling from G-protein. Mol. Pharmacol. 50: 1214-1222.

Pak, Y., O'Dowd, B.F., George, S.R. (1997). Agonist-induced desensitization of the $\mu$ opioid receptor is determined by Threonine 394 preceded by acidic aminoacids in the COOH-terminal tail. J. Biol. Chem. 272: 24961-24965.

Pampusch M.S., Osinski M.A., Brown D.R., Murtaugh M.P. (1998). The porcine mu opioid receptor: molecular cloning and mRNA distribution in lymphoid tissues. J. Neuroimmunol. 90(2): $192-$ 198.

Pan Y.X., Xu J., Pasternak G.W. (1996). Cloning and expression of a cDNA encoding a mouse brain orphanin FQ/nociceptin precursor. Biochem. J. 315 ( Pt 1): 11-13.

Pan Y.X., Xu, J., Mauther, L., Bolan, E., Xu, M., Pasternak, G.W. (2001). Generation of the mu opioid receptor (MOR-1) protein by the three new splice variants of the Oprm gene. PNAS 98(24): 1484-1489.

Pasternak G.W. (1988). The opiate receptors. Humana Press. Clifton, New Jersey.

Pasternak G.W. (2001). Insights into mu opioid pharmacology. The role of mu opioid receptor subtypes. Life Sci. 68: 2213-2219.

Pasternak, G.W., Wood, P.J. (1986). Multiple $\mu$ opiate receptors. Life Sci. 38: 1889-1898.

Paul D, Levison JA, Howard DH, Pick CG, Hahn EF, Pasternak GW. (1990). Naloxone benzoylhydrazone (NalBzoH) analgesia. J. Pharmacol. Exp. Ther. 255(2): 769-774.

Pepin M.C., Yue S.Y., Roberts E., Wahlestedt C., Walker P. (1997). Novel restoration of function mutagenesis strategy to identify amino acids of the $\delta$-opioid receptor envolved in ligand binding. $J$. Biol. Chem. 272: 9260-9267.

Pert C.B., Snyder S.H. (1973). Opiate receptors: its demonstration in nervous tissue. Science 179: 1011-1014.

Pinal-Seoane N., Martin I.R., Gonzalez-Nunez V., de Velasco E.M., Alvarez F.A., Sarmiento R.G., Rodriguez R.E. (2006). Characterization of a new duplicate delta-opioid receptor from zebrafish. J. Mol. Endocrinol. 37(3): 391-403. 
Pogozheva I.D., Lomize A.L., Mosberg H.I. (1998). Opioid receptor three-dimensional structures from distance geometry calculations with hydrogen bonding constrains. Biophys. J. 75: 612-634.

Porteros A., García-Isidoro M., Barrallo A., González-Sarmiento R., Rodríguez R.E. (1999). Expression of ZFOR1, a delta-opioid receptor, in the central nervous system of the zebrafish (Danio rerio). J. Comp. Neurol. 412(3): 429-438.

Qiu Y., Law P.Y., Loh H.H. (2003). Mu-opioid receptor desensitization: role of receptor phosphorylation, internalization, and representation. J. Biol. Chem. 278(38): 36733-36739.

Quintana J., Wang H., Ascoli M. (1993). The regulation of the binding affinity of the luteinizing hormone/choriogonadotropin receptor by sodium ions is mediated by a highly conserved aspartate located in the second transmembrane domain of G protein-coupled receptors. Mol. Endocrinol. 7(6): $767-775$

Raynor K., Kong H., Chen Y., Yasuda K., Yu L., Bell G.I. (1994). Reisine T.Pharmacological characterization of the cloned kappa-, delta-, and mu-opioid receptors. Mol. Pharmacol. 45(2): 330334.

Reinscheid R.K., Ardati A., Monsma F.J. Jr., Civelli O. (1996). Structure-activity relationship studies on the novel neuropeptide orphanin FQ. J. Biol. Chem. 271(24): 14163-14168.

Reinscheid R.K., Nothacker H.P., Bourson A., Ardati A., Henningsen R.A., Bunzow J.R., Grandy D.K., Langen H., Monsma F.J., Civelli O. (1995). Orphanin FQ: a neuropeptide that activates an opioid like G protein-coupled receptor. Science. 270: 792-794.

Reisine T. (1995). Neurotransmiter recepotors V. Opiate receptors. Neuropharmacology. 34(5): 463472.

Reisine T., Law, S.F., Blake, A., Tallent, M. (1996). Molecular mechanisms of opiate receptor coupling to $\mathrm{G}$ proteins and effector systems. Annu. N.Y. Acad. Sci. 780: 168-175.

Remmers A.E., Clark M.J., Alt A., Medzihradsky F., Woods J.H., Traynor J.R. (2000). Activation of $\mathrm{G}$ protein by opioid receptors: role of receptor number and G-protein concentration. Eur. $J$.

Pharmacol. 396(2-3): 67-75.

Rivas Boyero A.A. (2003). Clonación y caracterización del receptor ORL en pez cebra (Danio rerio). Tesis doctoral. Universidad de Salamanca. 
Rodriguez R.E., Barrallo A., Garcia-Malvar F., McFadyen I.J., Gonzalez-Sarmiento R., Traynor J.R. (2000). Characterization of ZFOR1, a putative delta-opioid receptor from the teleost zebrafish (Danio rerio). Neurosci Lett. 288(3): 207-210.

Rothman R.B., Xu H., Wang J.B., Partilla J.S., Kayakiri H., Rice K.C., Uhl G.R. (1995). Ligand selectivity of cloned human and rat opioid mu receptors. Synapse. 21(1): 60-64.

Rottbauer W., Baker K., Wo Z.G., Mohideen M.A., Cantiello H.F., Fishman M.C. (2001). Growth and function of the embryonic Herat depend upon the cardiac-specific L-type calcium channel alpha 1 subunit. Dev. Cell. 1(2): 265-275.

Saidak Z., Blake-Palmer K., Hay D.L., Northup J.K. (2006). Differential activation of G-proteins by mu-opioid receptor agonists. Br. J. Pharmacol. 147(6): 671-680.

Salamon Z., Hruby V.J., Tollin G., Cowell S. (2002). Binding of agonists, antagonists and inverse agonists to the human delta-opioid receptor produces distinctly different conformational states distinguishable by plasmon-waveguide resonance spectroscopy. J. Pept. Res. 60(6): 322-328.

Samama P., Cotecchia S., Costa T., Lefkowitz R.J. (1993). A mutation-induced activated state of the beta 2-adrenergic receptor. Extending the ternary complex model. J. Biol. Chem. 268(7): 4625-4636.

Satoh M., Minami M. (1995). Molecular pharmacology of the opioid receptors. Pharmacology Therapeutics. 68(3): 343-364.

Savarese T.M., Fraser C.M. (1992). In vitro mutagenesis and the search for structure-function relationships among G protein-coupled receptors. Biochem. J. 283(1): 1-19.

Scheer A., Fanelli F., Costa T., De Benedetti P.G., Cotecchia S. (1997). The activation process of the alpha1B-adrenergic receptor: potential role of protonation and hydrophobicity of a highly conserved aspartate. Proc. Natl. Acad. Sci. USA. 94(3): 808-813.

Schuller A.G.P., King, M., Zhang, J., Czick, M., Unterwald, E., Pasternak, G.W., Pintar, J.E. (1997). Heroin and M6G analgesia are retained in $\mathrm{m}$ opioid receptor deficient mice. Society for Neuroscience 27th Annual Meeting. New Orleans, USA.

Segredo V., Burford N.T., Lameh J., Sadée W. (1997). A constitutively internalizing and recycling mutant of the mu-opioid receptor. J. Neurochem. 68(6): 2395-2404. 
Seki T., Minami M., Kimura C., Uehara T., Nakagawa T., Satoh M. (1998a). Bremazocine recognizes the difference in four amino acid residues to discriminate between a nociceptin/orphanin FQ receptor and opioid receptors. Jpn. J. Pharmacol. 77(4): 301-306.

Seki T., Minami M., Nakagawa T., Ienaga Y., Morisada A., Satoh M. (1998b). DAMGO recognizes four residues in the third extracellular loop to discriminate between mu- and kappa-opioid receptors. Eur. J. Pharmacol. 350(2-3): 301-310.

Self D. W., Nestler E.J. (1995). Molecular mechanisms of drug reinforcement and adiction. Annu. Rev. Neurosci. 18: 463-495.

Shin JT, Fishman MC. (2002). From Zebrafish to human: modular medical models. Annu Rev Genomics Hum. Genet. 3: 311-340.

Simon E.J., Hiller J.M., Edelman I. (1973). Stereospecific binding of the potent narcotic analgesic $\left[{ }^{3} \mathrm{H}\right]$ - etorphine to rat brain homogenate. Proc. Natl. Acad. Sci. USA 70: 1947-1049.

Simonin F., Gaveriaux-Ruff C., Befort K., Matthes H., Lannes B., Micheletti G., Mattei M.G., Charron G., Bloch B., Kieffer B. (1995). Kappa-opioid receptor in humans: cDNA and genomic cloning, chromosomal assignment, functional expression, pharmacology, and expression pattern in the central nervous system. Proc. Natl. Acad. Sci. USA. 92(15): 7006-7010.

Smart D., Lambert, D.G. (1996). $\delta$ opioids stimulate inositol 1,4,5-trisphosphate formation, and so mobilize $\mathrm{Ca}^{+2}$ from intracellular stores, in undifferentiated NG108-15 cells. J. Neurochem. 66: $1462-$ 1467.

Smith C.F., Rance M.J. (1983). Opiate receptors in the rat vas deferens. Life Sci. 33(1): 327-330.

Sneddon L.U. (2003). The evidence for pain in fish: the use of morphine as an analgesic. Appl. Anim. Behav. Sci. 83: 153-162.

Snyder S.H. (1996). Drugs and the brain. W.H. Freeman and Company. Oxford.

Snyder S.H., Pasternak G.W. (2003). Historical review: Opioid receptors. TRENDS in Pharmacological Sciences. 24(4): 198-205.

Sofuoglu M., Portoghese P.S., Takemori A.E. (1991). Differential antagonism of d opioid agonists by naltrindole and its benzofuran analog (NTB) in mice: evidence for $\delta$ opioid receptor subtypes. $J$. Pharmacol. Exp. Ther. 257: 676-680. 
Sora I., Takahashi N., Funada M., Ujike H., Revay R.S., Donovan D.M., Miner L.L., Uhl G.R. (1997). Opiate receptor knock-out mice define $\mathrm{m}$ receptor roles in endogenous nociceptive responses ans morphine-induced analgesia. Proc. Natl. Acad. Sci. USA 94: 1544-1549.

Spence R., Jordan W.C., Smith C. (2006). Gene análisis of male reproductive success in relation to density in the zebrafish, Danio rerio. Front Zool. 5: 3-5.

Spivak C.E., Beglan C.L., Seidleck B.K., Hirshbein L.D., Blaschak C.J., Uhl G.R., Surratt C.K. (1997). Naloxone activation of mu-opioid receptors mutated at a histidine residue lining the opioid binding cavity. Mol. Pharmacol. 52(6): 983-992.

Sternini C., Spann M., Anton B., Keith D.E. Jr, Bunnett N.W., von Zastrow M., Evans C., Brecha N.C. (1996). Agonist-selective endocytosis of mu opioid receptor by neurons in vivo. Proc. Natl. Acad. Sci. USA. 93(17): 9241-9246.

Stevens C.W. (2004). Opioid research in amphibians: an alternative pain model yielding insights on the evolution of opioid receptors. Brain Res. Brain Res. Rev. 46(2): 204-215.

Strader C.D., Sigal I.S., Candelore M.R., Rands E., Hill W.S., Dixon R.A. (1988). Conserved aspartic acid residues 79 and 113 of the beta-adrenergic receptor have different roles in receptor function. J. Biol. Chem. 263(21): 10267-10271.

Streisinger, G., Walker, C., Dower, N., Knauber, D., Singer, F. (1981). Production of clones of homozygous diploid zebrafish (Brachydanio rerio). Nature. 291: 293-296.

Surratt C.K., Adams W.R. (2005). G protein-coupled receptor structural motifs: relevance to the opioid receptors. Curr. Top. Med. Chem. 5(3): 315-324.

Surratt C.K., Johnson P.S., Moriwaki A., Seidleck B.K., Blaschak C.J., Wang J.B., Uhl G.R. (1994). -mu opiate receptor. Charged transmembrane domain amino acids are critical for agonist recognition and intrinsic activity. J. Biol. Chem. 269(32): 20548-20553.

Szüics M., Boda K., Gintzler A.R. (2004). Dual effects of DAMGO [D-Ala2,N-Me-Phe4,Gly5-ol]enkephalin and CTAP (D-Phe-Cys-Tyr-D-Trp-Arg-Thr-Pen-Thr-NH2) on adenylyl cyclase activity: implications for mu-opioid receptor Gs coupling. J. Pharmacol. Exp. Ther. 310(1): 256-62.

Tamura K, Dudley J, Nei M, Kumar S. (2007). MEGA4: Molecular Evolutionary Genetics Analysis (MEGA) software version 4.0. Mol. Biol. Evol. 24(8): 1596-1599. 
Terenius L. (1973). Stereospecific interaction between narcotic analgesic and synaptic plasma membrane fraction of rat cerebral cortex. Acta Pharmacol. Toxicol. 32: 317-320.

Thompson R.C., Mansour A., Akil H., Watson S.J. (1993). Cloning and pharmacological characterization of a rat mu opioid receptor. Neuron. 11(5): 903-913.

Toll L. (1992). Comparison of mu opioid receptor binding on intact neuroblastoma cells with guinea pig brain and neuroblastoma cell membranes. J. Pharmacol. Exp. Ther. 260(1): 9-15.

Trapaidze N., Keith D.E., Cvejic S., Evans C.J., Devi L.A. (1996). Sequestration of the delta opioid receptor. Role of the C terminus in agonist-mediated internalization. J. Biol. Chem. 271(46): 2927929285.

Traynor J.R., Nahorski S.R. (1995). Modulation by mu-opioid agonists of guanosine-5'-O-(3[35S]thio)triphosphate binding to membranes from human neuroblastoma SH-SY5Y cells. Mol. Pharmacol. 47(4): 848-854.

Trede N.S., Langenau D.M., Traver D., Look A.T., Zon L.I. (2004). The use of zebrafish to understand immunity. Immunity. 20(4): 367-379.

Trumpp-Kallmeyer S., Hoflack J., Bruinvels A., Hibert M. (1992). Modeling of G-protein-coupled receptors: application to dopamine, adrenaline, serotonin, acetylcholine, and mammalian opsin receptors. J. Med. Chem. 35(19): 3448-3462.

Ueda H., Miyamae T., Hayashi C., Watanabe S., Fukushima N., Sasaki Y., Iwamura T, Misu Y. (1995). Protein kinase C involvement in homologous desensitization of delta-opioid receptor coupled to Gi1-phospholipase C activation in Xenopus oocytes. J. Neurosci. 15(11): 7485-7499.

Uhl G.R., Childers S. Pasternak G.W. (1994). An opiate-receptor gene family reunion. Trends Neurosci. 17: 89-93.

Waldhoer M., Bartlett S.E., Whistler J.L. (2004). Opioid receptors. Annu. Rev. Biochem. 73: 953990 .

Wang C.D., Buck M.A., Fraser C.M. (1991). Site-directed mutagenesis of alpha 2A-adrenergic receptors: identification of amino acids involved in ligand binding and receptor activation by agonists. Mol. Pharmacol. 40(2): 168-179. 
Wang D., Surratt C.K., Sadée W. (2000). Calmodulin regulation of basal and agonist-stimulated G protein coupling by the mu-opioid receptor $(\mathrm{OP}(3))$ in morphine-pretreated cell. J. Neurochem. $75(2)$ : 763-771.

Wang J.B., Imai Y., Eppler C.M., Gregor P., Spivak C.E., Uhl G.R. (1993). mu opiate receptor: cDNA cloning and expression. Proc. Natl. Acad. Sci. USA. 90(21): 10230-10234.

Wang J.B., Johnson P.S., Imai Y., Persico A.M., Ozenberger B.A., Eppler C.M., Uhl G.R. (1994b). cDNA cloning of an orphan opiate receptor gene family member and its splice varian. FEBS Lett. 348: 75-79.

Wang J.B., Johnson P.S., Persico A.M., Hawkins A.L., Griffin C.A., Uhl G.R. (1994a). Human mu opiate receptor. cDNA and genomic clones, pharmacologic characterization and chromosomal assignment. FEBS Lett. 338(2): 217-222.

Wang W., Loh H.H., Law P.Y. (2003). The intracellular trafficking of opioid receptors directed by carboxyl tail and a di-leucine motif in Neuro2A cells. J. Biol. Chem. 278(38): 36848-36858.

Wang W.W., Shahrestanifar M., Jin J., Howells R.D. (1995). Studies on mu and delta opioid receptor selectivity utilizing chimeric and site-mutagenized receptors. Proc. Natl. Acad. Sci. USA. 92(26): 12436-12440.

Wang Z., Bilsky E.J., Porreca F., Sadée W. (1994c). Constitutive mu opioid receptor activation as a regulatory mechanism underlying narcotic tolerance and dependence. Life Sci. 54(20): 339-350.

Watson B., Meng F., Akil H. (1996). A chimeric analysis of the opioid receptor domains critical for the binding selectivity of mu opioid ligands. Neurobiol Dis. 3(1): 87-96.

Wess J. (1993). Molecular basis of muscarinic acetylcholine receptor function. Trends. Pharmacol. Sci. 14(8): 308-313.

Wess J. (1998). Molecular basis of receptor/G-protein-coupling selectivity. Pharmacol. Ther. 80(3): 231-264.

Whistler J.L., Chuang H.H., Chu P., Jan L.Y., von Zastrow M. (1999). Functional dissociation of $\mathrm{mu}$ opioid receptor signaling and endocytosis: implications for the biology of opiate tolerance and addiction. Neuron. 23(4): 737-746.

Willis W.D., Westlund K.N. (1997) Neuroanatomy of the pain system and of the pathways that modulate pain. J. Clin. Neurophys. 14: 2-31. 
Wolf R., Koch T., Schulz S., Klutzny M., Schröder H., Raulf E., Bühling F., Höllt V. (1999). Replacement of threonine 394 by alanine facilitates internalization and resensitization of the rat mu opioid receptor. Mol. Pharmacol. 55(2): 263-268.

Xu W., Ozdener F., Li J.G., Chen C., de Riel J.K., Weinstein H., Liu-Chen L.Y. (1999). Functional role of the spatial proximity of Asp114(2.50) in TMH 2 and Asn332(7.49) in TMH 7 of the mu opioid receptor. FEBS Lett. 447(2-3): 318-324.

Xu X., Meiler S.E., Zhong T.P., Mohideen M., Crossley D.A., Burggren W.W., Fishman M.C. (2002). Cardiomyophaty in zebrafish due to mutation in an alternatively spliced exon of titin. Nat. Genet. 30(2): 205-209.

Yasuda K., Raynor K., Kong H., Breder C.D., Takeda J., Reisine T., Bell G.I. (1993). Cloning and functional comparison of $\kappa$ and $\delta$ opioid receptors from the mouse brain. Proc. Natl. Acad. Sci. USA. 90: 6736-6740.

Yue X., Varga E.V., Stropova D., Vanderah T.W., Yamamura H.I., Roeske W.R. (2006). Chronic morphine-mediated adenylyl cyclase superactivation is attenuated by the Raf-1 inhibitor, GW5074. Eur. J. Pharmacol. 540(1-3): 57-59.

Zadina J.E., Hackler L., Ge L.J., Kastin A.J. (1997). A potent and selective endogenous agonist for the $\mu$-opiate receptor. Nature 386: 499-502.

Zaki P.A., Keith D.E. Jr, Brine G.A., Carroll F.I., Evans C.J. (2000). Ligand-induced changes in surface mu-opioid receptor number: relationship to G protein activation? J. Pharmacol. Exp. Ther. 292(3): 1127-1134.

Zastawny R.L., George S.R., Nguyen T., Cheng R., Tsatsos J., Briones-Urbina R., O'Dowd B.F. (1994). Cloning, characterization, and distribution of a m-opioid receptor in rat brain. Journal of Neurochemistry. 92(6): 2099-2105.

Zhang S., Tong Y., Tian M., DeHaven R.N., Cortesburgos L., Mansson E., Simonin F., Kieffer B., Yu L. (1998). Dynorphin A as a potencial endogenous ligand for tour members of the opioid receptor gene family. J. Pharmacol. Exp. Ther. 286(1): 136-141.

Zieglgänsberger W., Tölk T.R. (1993). The pharmacology of pain signaling. Current Biol. 3: 611618. 
Zimprich A., Simon T., Höllt V. (1995) Cloning and exression of an isoform of the rat mu opioid receptor (rMOR1B) which differs in agonist induced desensitization from rMOR1. FEBS. Letters. 359: $142-146$. 

Anexo I 

Ratón

Rata

Humano

Pez cebra

\section{Ratón}

Rata

Humano

Pez cebra

Ratón

Rata

Humano

Pez cebra

Ratón

Rata

Humano

Pez cebra

Ratón

Rata

Humano

Pez cebra

\section{Ratón}

Rata

Humano

Pez cebra
MDSSAGPGNISDCSDPLAPASCSPAP--GSWLNLSHVDGNOSDPCGPNRTGLGGSHSLCP 58 MDSSTGPGNTSDCSDPLAQASCSPAP--GSWLNLSHVDGNQSDPCGLNRTGLGGNDSLCP 58 MDSSAAPTNASNCTDALAYSSCSPAPSPGSWVNLSHLDGNLSDPCGPNRTDLGGRDSLCP 60 MMENTG--NISDLLYALSNPMVSNSS------ILCRNFSNSSGLVNMN-SSVCDRTPELD 51

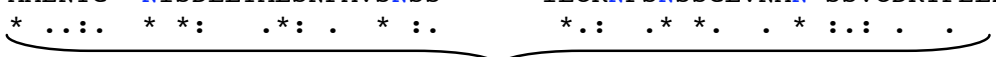

N-terminal

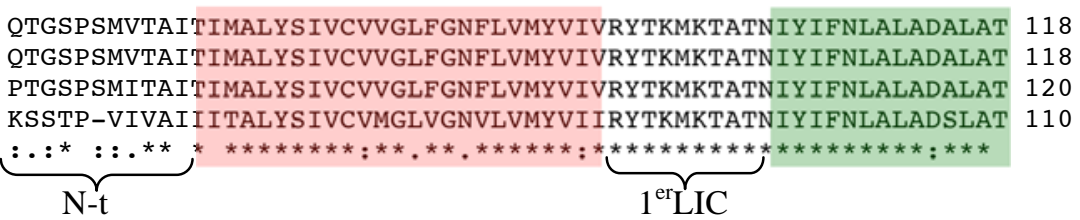

STLPFQSVNYLMGTWPFGNILCKIVISIDYYNMFTSIFTLCTMSVDRYIAVCHPVKALDF 178 STLPFOSVNYLMGTWPFGTILCKIVISIDYYNMFTS IFTLCTMSVDRY IAVCHPVKALDF 178 STLPFQSVNYLMGTWPFGTILCKIVISIDYYNMFTS IFTLCTMSVDDYIAVCHPVKALDF 180 STLPFQSVNYLMGTWPFGDELCKIVMS IDYYNMFTS IFTLTTMSVDRYIAVCHPVKALDF 170

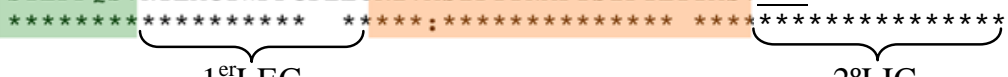
$1^{\mathrm{er}} \mathrm{LEC}$

$2^{\circ} \mathrm{LIC}$

RTPRNAKIVNVCNWILSSAIGLPVMFMATTK---YRQGSIDCTLTFSHPTWYWENLLKIC 235 RTPRNAKIVNVCNWILSSAIGLPVMFMATTK---YRQGS IDCTLTFSHPTWYWENLLKIC 235 RTPRNAK I INVCNWILSSAIGLPVMFMATTK---YROGS IDCTLTF SHPTWYWENLLK IC 237 RTPRNAK IVNVCNWILSSAIGLPVMVMASTTSDLHSNGI IDCTLLFPHPSWYWENLLK IC 230

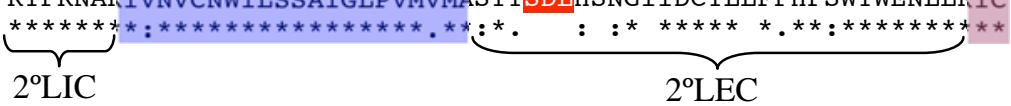

VFIFAFIMPVLIITVCYGLMILRLKSVRMLSGSKEKDRNLRRITRMVLVVVAVFIVCWTP 295 VFIFAF IMPVL I ITVCYGLMILRLKSVRMLSGSKEKDRNLRRITRMVLVVVAVFIVCWTP 295 VFIFAF IMPVL I ITVCYGLMILRLKSVRMLSGSKEKDRNLRRITRMVLVVVAVFIVCWTP 297 VFIFAF IMPVL I TVCYGLMILRLKSVRMLSGSKEKDRNLRRITRMVLVVVAVFIVCWTP 290

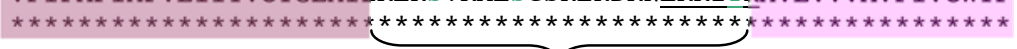
$3^{\mathrm{er}} \mathrm{LIC}$

IHIYVIIKALITIPETTFOTVSWHFCIALGYTNSCLNPVLYAFLDENFKRCFREFCIPTS 355 IHIYVI IKALITIPETTFOTVSWHFCIALGYTNSCLNPVLYAFLDENFKRCFREFCIPTS 355 IHIYVI IKALVTIPETTFQTVSWHFCIALGYTNSCLNPVLYAFLDENFKRCFREFCIPTS 357 IHIFVI IKALVTIPNSLLQTITWHFCIALGYTNSCLNPVLYAFLDENFKRCFREFCVPSP 350

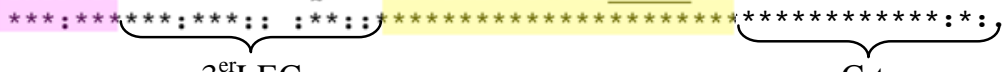
$3^{\mathrm{er}} \mathrm{LEC}$ C-t

En esta comparación de las secuencias de los receptores opioides mu de ratón, rata, humano y pez cebra se encuentran resaltados dominios y estructuras importantes. Los rectángulos de colores marcan los dominios transmembrana del receptor. Se encuentran señalados los lazos intracelulares (LIC) y los extracelulares (LEC), así como los extremos carboxilo y amino terminales. En el extremo amino terminal resaltados en azul se encuentran residuos de asparragina $(\mathrm{N})$ susceptibles de glicosilación. Solo se han considerado aquellos residuos que formen parte de la secuencia consenso de glicosilación Asn-X-Ser/Thr (siendo X cualquier aminoácido). Con flechas negras se indican posibles sitios de glicosilación que no aparecen en mamíferos. En el tercer lazo intracelular y el extremo carboxilo se resaltan en verde residuos de Serina $(\mathrm{S})$ y treonina $(\mathrm{T})$ susceptibles de fosforilación por kinasas intracelulares. También en el dominio carboxilo terminal las flechas rojas indican residuos de cisterna (C) susceptibles de palmitoilación. Las regiones subrayadas a lo largo se la secuencia se corresponden con secuencias conservadas en los receptores de 7 dominios transmembrana que se acoplan a proteínas $\mathrm{G}$ y que se han demostrado fundamentales para el correcto funcionamiento del receptor. Por último se encuentra resaltada la región del $2^{\circ}$ lazo extracelular que eliminó en el mutante originado en este trabajo 

Anexo II 

Gracias al proyecto de secuenciación del genoma del pez cebra hemos podido localizar las regiones codificantes que conforman el gen zfMOR. Afortunadamente toda la secuencia codificante se encuentra dentro de un mismo contig (conjunto de secuencias procedentes de distintas reacciones de secuenciación que se solapan parcialmente) por lo que obtenemos una idea bastante aproximada de la longitud de los intrones. El análisis de la secuencia del contig $\mathrm{CH} 211-160 H 10$ nos permite localizar los intrones y los exones. Puesto que el contig tiene más de 170.000 pares de bases no se pone la secuéncia completa.

//118.976//TTAAAATACTACACTGAGAACATACTTTCAGGACCACCAATCTTTAGTITGACCTCCTTTCGTGGAGTTAAAGCCTAA TTAGTGAAGTCAGACTTCCCTIITTGCATTCGGTAAATATAAAATCAAGCCATAAATTCAGCTGGAGAGATGAGGATGAGCGATTGT AAATTCATACATCTCTTCGACGATGAGAAAGTGACGAGCTGGAACCACCGGACTGCCGAAAAGCCTCTAGTCATGTGCATATATAC GTGACGTCATTTTGTTGAATAAAATGCGACGCTCGATACAATTTCACGAGGGTAATGCAAGAACTGCGGGGATAGATTTATCATAG AGTCTCGTAAACAAAAGAGACTACTATACTTGTGGCAGCAGCGGCGGGAGCAACATTAGACTGCCTCGGTTGATCGGTTGGGACTC GTTGAGTGTITTGAAGCGGACAGGTATCGATATCTGTGAGCGTGATTGATAAACAGCGCGCGCGTGCAGAACTTGGGCGAATATCA CCCGAACGGCACTTGCCATGATGGAAAACACCGGCAACATTTCGGACCTTCTGTACGCGCTTTCCAACCCAATGGTGTCGAATAGC AGCATATTCTGCCGAAACTTCAGCAACAGCTCCGGTCTCGTGAACATGAACAGCTCCGTATGTGACAGGACGCCAGAGCTGGACAA AAGCTCAACTCCAGTGATTGTGGCCATCATCATCACTGCCTTATACTCTATAGTGTGTGTGATGGGACTGGTGGGAAACGTCCTCG TCATGTATGTTATTATAAGGIAAGAGAAGACATGTAGGGGATTGTATTACGATGCATAAGATATTAGAGTTGTITGCTTCCTTTAA ATAGACATTITAGGTGATAGTITICTITATGCAATATGATAGTTGTTGCTITITAAAAGGGACCTGTTGAAGAGGTGCTGATTGT TाTCTGGTAATAGAAGTCGGCATTGCAGAAACTCCCTTIITTGCAGTCATTCAATCACTAAAGACGGCCTGTTAATAATAGAATAAA ATAATGTITIACTGTTGTAGTTIATTIATGCTTATGCTTGCTITTCATTTATAAAATAATATTAACGATTTACAGCTCAGAAATGTGT CTCTTCTCCACTGAGTGTGTGTACGCGTITCCGATGTTCCTGTCAGCGTATTGGAGAAAAACATTGCATTGTTTCGTTCACATTGAT TTCACACTTCATCTGATGCGGTGTAACACCGCATATTTTGCTAATCAGAAGTGCCGCTAAATAGAGATGCACTTATTITTGGAGAA AAAGAACGACAGTTCAATGAACAACTGGG //120296// //154440// ПTTTCAATTTATCTGACCATCCAATCCAACTGTCTCCCAATCTCTCTATTTATTCAATCCAACTGCCTCCCAATCTCTCCATCCATTCA TTCATCCATTTATCTGTTCTAAATTITTATGTATCCATCAATGCACTCATCCAATTGAAATATTAAAAGAGTGCTCAAAACTAGTAA ATTGAACTTGATTTGATTTGGCTCTACACTGTAGTTGTATTCATGCTGAGAAACATTTGCATAATGGTGTACATAATGGTGGTTATC TGGCCTCTTGAATTAACATTTCAATGAAGGTCATATTTGTATCATAAGATGCACATTGTACCTTTCTTAATGGCTTGAAGCAACATG TGTAGCTGAGTTCATTACTGGCTGTTTATTGGACAAAAAAAGAGTGCCCTTTCATGTATGTTTCTACAGTTCCCATAGCCATTACTC ACTCCGAAAACACATTGCATCTCATATTATTTAATAAAAGCAGTGAATGTAATGATCTCTACCTATTITTGTCCATTGCAGATACACC AAAATGAAAACTGCGACCAACATCTACATCTTCAACCTTGCTCTAGCAGATTCCTTGGCAACAAGTACTCTACCCTITCAGAGTGTG 
AATTACCTGATGGGTACATGGCCTTTTGGAGACGAGCTGTGCAAGATTGTGATGTCTATTGATTACTACAACATGTTCACCAGTATC TTTACTCTCACAACCATGAGTGTTGACCGTTACATAGCTGTTTGCCACCCGGTTAAAGCCTTGGACTTCAGAACGCCCCGAAATGCC AAGATCGTCAACGTGTGTAACTGGATCCTTTCATCTGCAATCGGTCTCCCTGTCATGGTCATGGCCTCCACCACTTCTGATCTGCAC TGTATGTTTACCACCACATTCTTCATTGTGAAAATTCAGATATTACTGTAGAAAAAGGATAGTCTTCACAAAAATGGCATTTCTGTT ATTTGCTTCTTTTCGTTTATTTATTTATTTATTTATTTATTTTTTGTTTGACTCACTTTCTATGAAACGAAAGAAGATATTTTAAAGA AATTTTGAACTGCTTTGTTCATAAAATGTAAACTAATTTGTAAAAGAATCTTTAGAAAAAGGAGAAATATCTTAATTTGGGTTTTATA GAATAAGGAATGCCAGCTTCAGAAGGGCATATGGATGAGAAATAAAACACAAATCTTCATTTGTTGTGAAACTACATTTAATTATGC CTTTATTTTTCTTTTAAGCCAATGACAATGAAAACTGTAATCAGTTTTACATTTTCAGCTGGGGTTTTTTCATGAAGGAAAATATGA TGTTGTGAAATAATACAAAATTGAAAAAGTTGGACTGAATACAGAGACAATTATATTCTCAACACTATGACTACAATTATCAAAACTA AACAAAATC //155936// //160248//

CTTATCATTACATATAAAATAAAACTTCTGAACCTAATTATAGGAGCCTAATAGAAAATGCTCATTAACAAGAAAAGAGGTCAGATG GATTTAAAGGGTTTTGCATCTGATCTCTTCATATTTTTTCCAGGCTGTTACACCCCACCAATTGTAAACCCCTACACTCATCCAATGT TTAACTTGATCCCCTCTTAATACATTAAGACATCTCTCTCAATACTGGAAGTGTTCCATTTTGTTCCTGTAGTGACACCAATTTTACA GACACTAGAGAAGTGTTGAAGCAGAAAATTGTTATTGAGTGAATTTAGATTGATGTCACTTCTAGTCATTTGGCAAGAAAATCAAAA TGTGGTTTAATAGCTGTAGCAGTGACTCAAAAGCTCTGTAAACAAAGCCATGAGGACCTAATGACTACTTGAAGCTAGAATTGATTT TCACATGTCTCACTGTGTTATTGTACTGTGGTGTATTCTCTCTTTCGTAGCGAATGGCATCATTGACTGCACTTTGCTCTTTCCCCA TCCGTCCTGGTACTGGGAGAACCTCCTGAAGATCTGCGTCTTCATCTTTGCCTTCATCATGCCCGTCCTCATCATCACCGTCTGCTA CGGCCTGATGATCCTCCGCCTAAAGAGCGTGCGAATGCTCTCTGGGTCAAAGGAGAAGGACCGCAACCTCCGGCGCATCACCCGAA TGGTGCTGGTGGTGGTGGCGGTTTTCATCGTTTGCTGGACGCCCATCCACATCTTCGTCATCATCAAAGCTCTGGTGACCATTCCC AACTCCCTCCTGCAGACCATCACCTGGCATTTCTGCATCGCCCTCGGCTACACCAACAGCTGCCTCAACCCGGTGCTCTATGCCTTC TTGGATGAAAACTTTAAGCGCTGTTTTCGGGAGTTCTGTGTTCCCAGCCCATCAGTTTTGGACTTGCAGAACTCCACCCGCAGCAG GAACCCCCAGCGTGATGGTCAGTCCAGTGGCCACACGGTAGACAGGACAAACCAGCAGGTATGACTAGTCCTGGAGATGTCATCAC TGGAGTCCCGCAGCCAGCCCAGTGTTGACATGAGCTCAGAGGTCACGCAGGTCACAACAGGTGTCTGACACCATCAGCGGTAGGTT CAACCTCTTTAAACATCTTGCTAGGCCTCTCACAGTTTTAGTTTGAGGAAAGACTGTTGAAATAGCTCTTTTTAACCCTCGATGACA CATCAATAAGCTAAGCTTATTTTAATGTCTGTGATGTTCACAGTCATGCACCTAATGTAAAGTTAGTCCAGCATTCAAGACTAATTC AGCATTCAACACTATAGTGGAGATCAAAATTAGAGAACAATTGAAGAGAACTATAGACTGTTTCCCAATATGCTTTTTTAAAGCTGT ATTGCGTCCATGTGTTCTTGTGCAATGTCATCATCAACCACCAAAGTTAAATTCCAAAACAAAAGGCCGCAAGAACAGAGGACGCAT GAAAGATCCCAGATGTGTTCTTGATATTAAGGATGTGTCAGTGCAGACTTGAGTGTAGTACTTGCTCTAGAAGTCCCAAAAGTCTA TGCAGCTGAATAAAGGCGGTGG //161832//....//170998//

En la secuencia se pueden observar los tres exones de zfMOR y están resaltados los puntos de corte y empalme de los mismos. Podemos ver que las señales son GT·AG, éstas están altamente conservadas y van a ser reconocidas por una maquinaria ribonucleoproteica que se encarga de la escisión y el empalme de los exones. 
Anexo III 

En un experimento de binding determinamos la capacidad de unión de un ligando a un receptor. Cuando el ligando que queremos estudiar está marcado de forma radiactiva podemos realizar experimentos de saturación. Por el contrario cuando no disponemos del ligando en forma radiactiva debemos realizar ensayos de desplazamiento o competición.

Uno de los puntos clave en este tipo de experimentos es poder distinguir entre el ligando radiactivo que se encuentra unido al receptor de aquel que se encuentra libre en la solución. Existen varios métodos para conseguir la separación de éstos. Se puede hacer, por ejemplo, mediante centrifugación de la muestra; de esta manera las membranas sedimentarán con mucha facilidad mientras que en el sobrenadante quedará el ligando libre. Otra posibilidad es la utilización de un sistema de filtración, que ha sido nuestro caso. Pasando las muestras a través de filtros de fibra de vidrio con un tamaño de poro reducido conseguimos que las membranas, donde se encuentran las proteínas, queden retenidas en el filtro mientras que el ligando libre lo atravesará. Posteriormente podemos medir la radiactividad que ha quedado en el filtro y analizarla.

Otro punto muy importante en este tipo de experimentos es poder diferenciar entre la unión específica, es decir, lo que se une al receptor, de la unión inespecífica, lo que se une a otros componentes de la muestra. Para ello utilizamos un compuesto con alta afinidad por el receptor, en nuestro caso la naloxona. Si en un tubo ponemos el extracto purificado de membranas, donde se encontrarán los receptores, y añadimos diprenorfina tritiada, está se unirá al receptor de interés de forma específica, sin embargo, como hemos dicho antes también se unirá de forma inespecífica a otras proteínas o componentes de la muestra. Si en otro tubo añadimos las proteínas y el 
compuesto radiactivo y además una concentración saturante de naloxona, esta desplazará a la diprenorfina tritiada de los sitios de unión específicos. Tras filtrar las muestras obtendremos unos valores de radiactividad que denominamos TOTALES, en los tubos en los que no había naloxona y otros que denominamos NO ESPECÍFICOS, en los tubos en los que sí había naloxona. La diferencia entre el total y el no específico no dará la UNIÓN ESPECÍFICA del ligando al receptor.

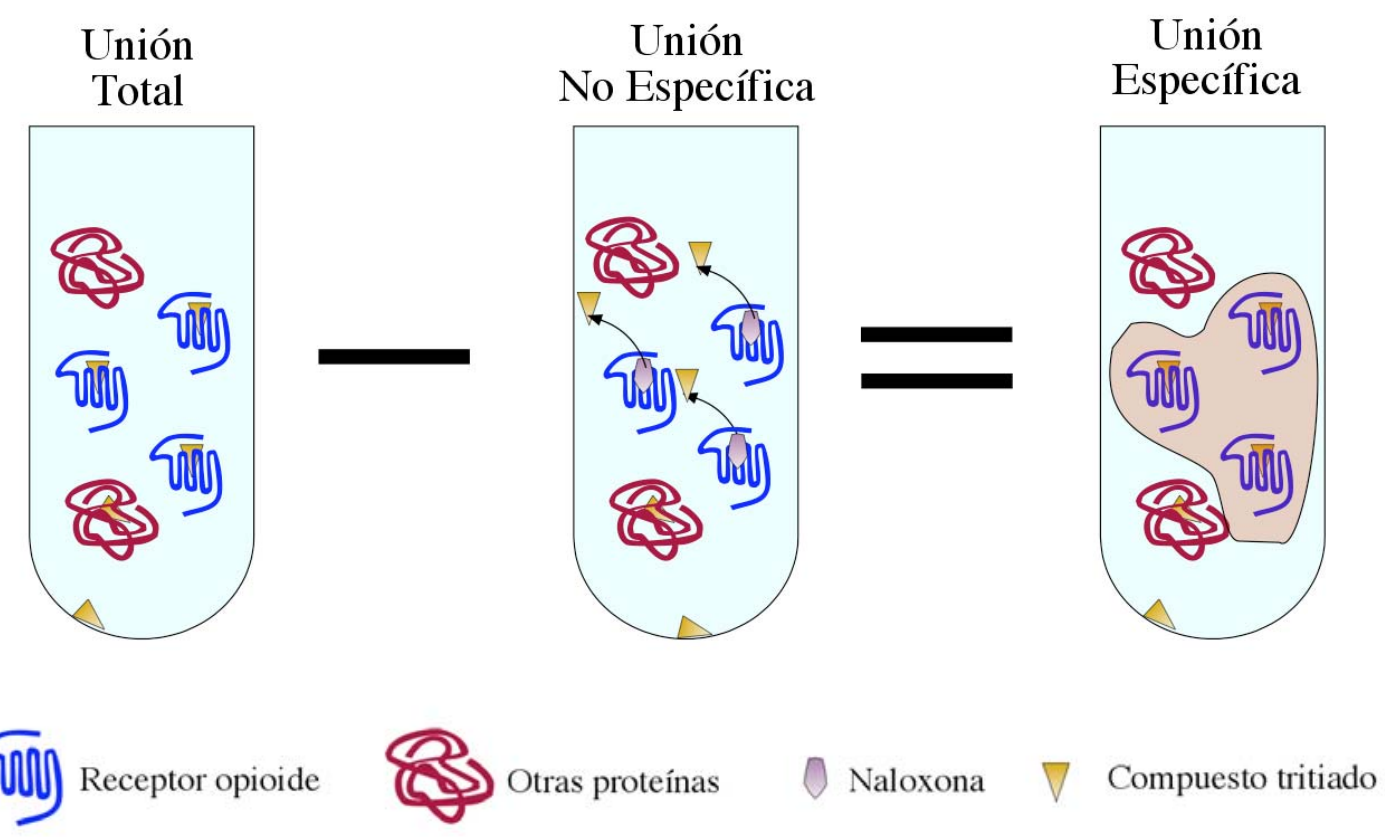

En los ensayos de saturación utilizaremos varias concentraciones de radioligando que nos producirán distintos valores de unión específica. A mayor concentración de radioligando utilizado mayor será la unión específica del mismo al receptor. Sin embargo, se alcanzará un punto en el que por más que se aumente la concentración de radioligando no aumentará la unión específica, en este punto todos los sitios de unión específica presentes en la muestra habrán sido ocupados por el radioligando, es decir, se habrá saturado. Si los datos obtenidos se representan de forma gráfica, unión específica frente a concentración de radioligando, obtendremos una curva hiperbólica llamada curva de saturación. Esta curva presenta una asíntota 
que nos dará el valor de unión máxima $\left(\mathrm{B}_{\mathrm{max}}\right)$ del ligando al receptor y que nos indica la población receptorial. En función de cómo se analicen los resultados el valor de $\mathrm{B}_{\max }$ se puede dar como fmol de receptor/mg de proteína total, como mg de receptor o como número de sitios de unión por célula, por ejemplo. La concentración de radioligando necesaria para ocupar la mitad de los sitios disponibles $\left(\mathrm{B}_{\max } / 2\right.$ y extrapolado al eje de abcisas) es la definición de la constante de disociación o $\mathrm{K}_{\mathrm{d}}$, un valor que representa la afinidad del ligando por el receptor.

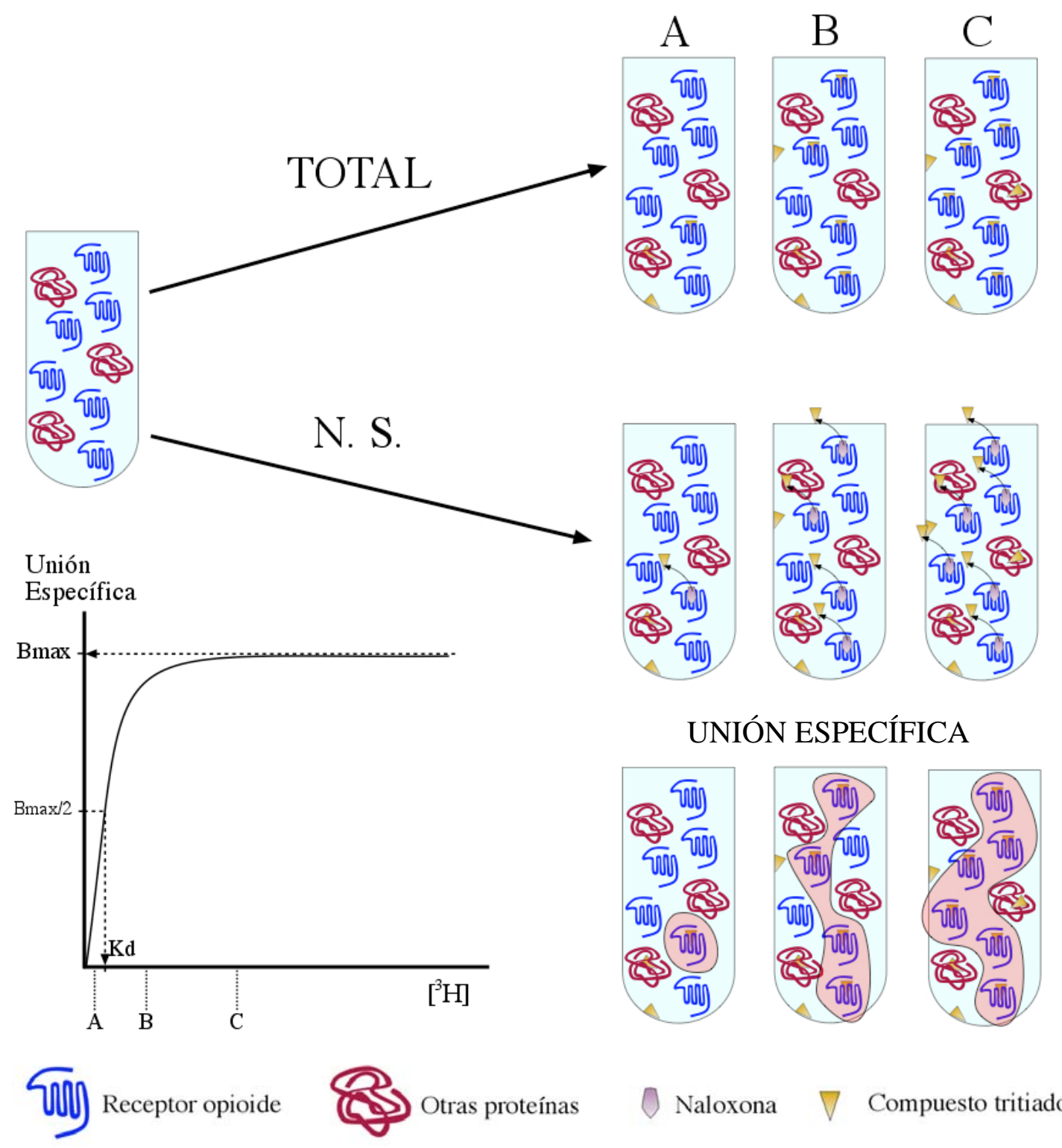

En este ejemplo se utilizan tres concentraciones distintas de radioligando (A, B y C) que producirán tres valores de unión específica tras restar la unión total de la inespecífica. Representando la unión específica frente a la concentración de radioligando obtendremos la curva de saturación a partir de la cual calcularemos los valores de $\mathrm{K}_{\mathrm{d}} \mathrm{y} \mathrm{B}_{\max }$. 
En los experimentos de desplazamiento o competencia se determina el valor de afinidad de un ligando, el cual no se tiene de forma radiactiva, por un receptor. En este tipo de experimentos se utiliza una concentración constante de un radioligando que va a ser desplazada por distintas concentraciones de ligando sin marcar o ligando frío que se quiere estudiar. De modo análogo a como ocurría con la naloxona, el ligando frío va a desplazar al ligando radiactivo de los sitios de unión específicos, y la cantidad de desplazamiento dependerá de la concentración a la que se encuentre el ligando frío y de la afinidad de éste por el receptor. Cuando la concentración de ligando frío es muy baja, todo o casi todo el ligando radiactivo estará unido al receptor (concentración 1 en la figura). A medida que la concentración va aumentando se irá desplazando el ligando radiactivo (concentración 2 en la figura). Cuando la concentración del ligando frío sea muy alta, nada o casi nada del ligando radiactivo quedará unido al receptor (concentración 3 en la figura). También utilizaremos un tubo que nos dará la unión total del radioligando al receptor (en ausencia de ligando frío) y otro que nos dará la unión no específica (utilizando naloxona). Los valores de estos tubos nos darán el 100 y el $0 \%$ de unión y los resultados obtenidos para cada una de las concentraciones los normalizaremos atendiendo a esos valores. Representando gráficamente obtenemos una curva de tipo sigmoide de la cual podremos determinar el valor de $\mathrm{EC}_{50}$ o dosis efectiva media. Este valor es una medida de la afinidad del ligando por el receptor y se define como la concentración de ligando frío necesaria para desplazar el 50 \% de los sitios de unión. Sin embargo este valor no se puede comparar entre distintos experimentos ya que depende de la concentración de radioligando utilizada, así como del valor de $\mathrm{K}_{\mathrm{d}}$ de dicho ligando por el receptor. Para poder comparar entre distintos experimentos es mejor utilizar el valor de $\mathrm{K}_{\mathrm{i}}$ obtenido mediante la ecuación de Cheng-Prusoff. 


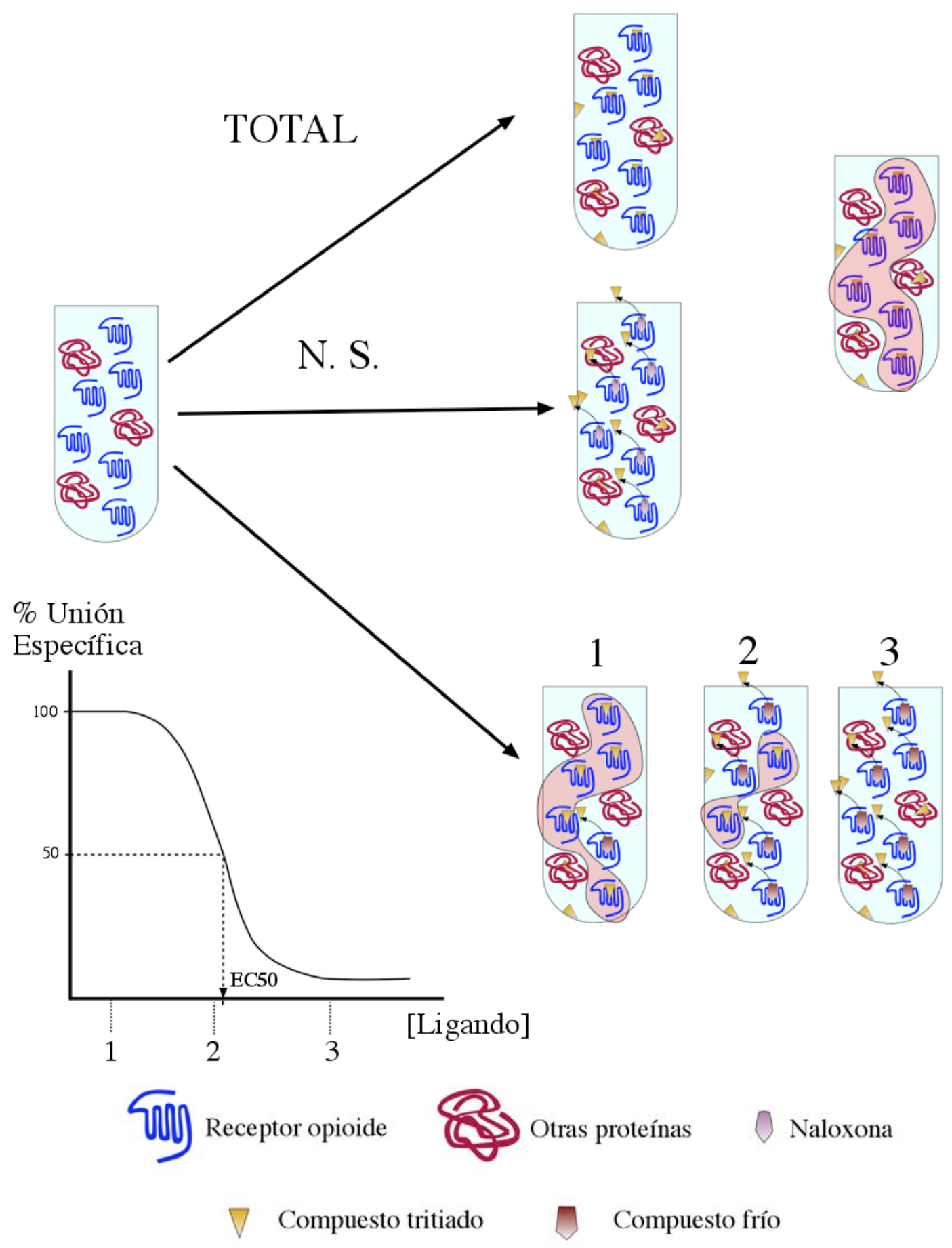

En este ejemplo se utiliza una concentración de radioligando fija y 3 concentraciones distintas de ligando frío (1, 2 y 3 ) que producirán tres valores de desplazamiento. Representando el porcentaje de unión específica del radioligando frente a la concentración de ligando frío obtendremos la curva de desplazamiento a partir de la cual calcularemos los valores de $\mathrm{EC}_{50} \mathrm{y} \%$ de desplazamiento máximo. 
En los experimentos de activación mediante la técnica de $\left[{ }^{35} \mathrm{~S}\right]-\mathrm{GTP} \gamma \mathrm{S}$ determinamos la capacidad de un ligando de producir la activación de las proteínas G. En una situación basal la subunidad alfa de las proteínas G tendrá GDP unido y estará en una forma inactiva. En presencia de un agonista, el receptor se activará, activando a la proteína G, lo que consiste en un intercambio de GDP por GTP. Finalmente la actividad GTPasa intrínseca de la subunidad alfa de la proteína G degradará el GTP a GDP y ortofosfato provocando la inactivación de la misma.

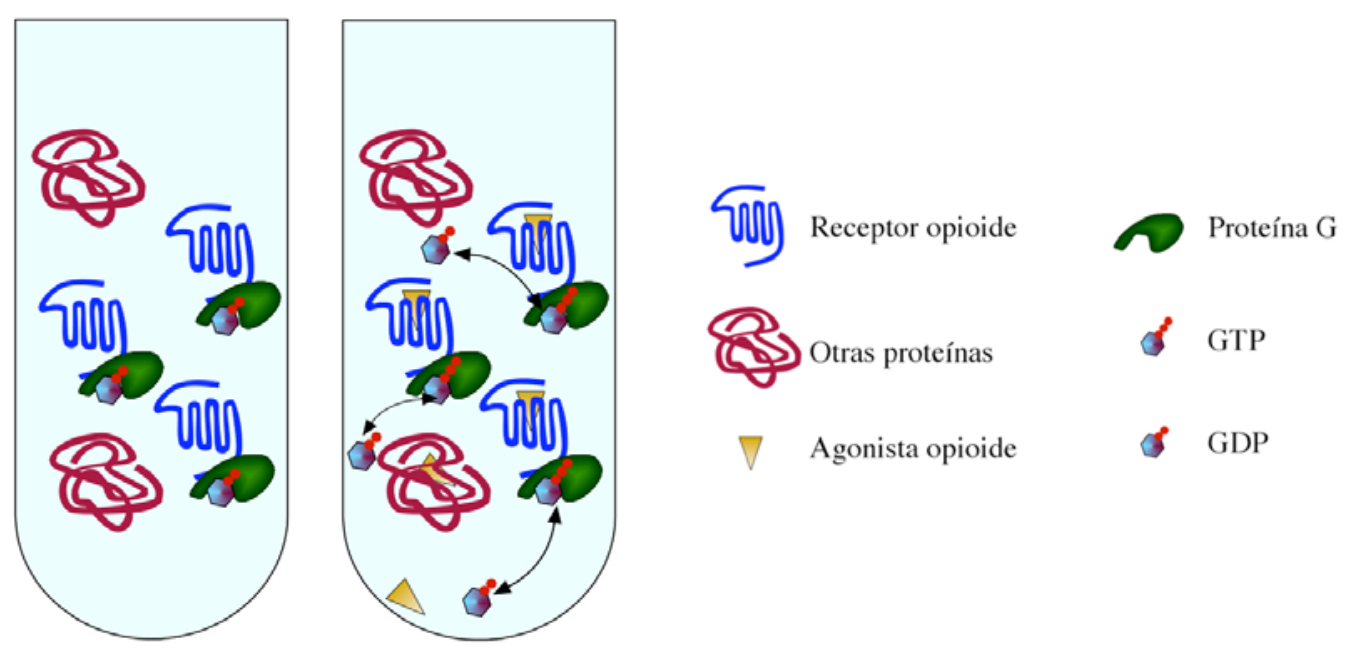

En este método lo que determinamos es la capacidad de unión de $\left[{ }^{35} \mathrm{~S}\right]-\mathrm{GTP} \gamma \mathrm{S}$ a las proteínas $\mathrm{G}$, tras la activación de éstas por parte del receptor. Al igual que en los casos anteriores es fundamental poder separar el $\left[{ }^{35} \mathrm{~S}\right]-\mathrm{GTP} \gamma \mathrm{S}$ que está unido del libre y para ello utilizamos también la técnica de filtración. Además también es importante poder diferenciar entre la unión específica del $\left[{ }^{35} \mathrm{~S}\right]-\mathrm{GTP} \gamma \mathrm{S}$ a las proteínas G de la unión inespecífica a otras proteínas o componentes de la muestra. Para poder realizar esta distinción, y de forma análoga a la utilización de naloxona en los experimentos de saturación y desplazamiento, utilizamos GTP $\gamma \mathrm{S}$ frío. 

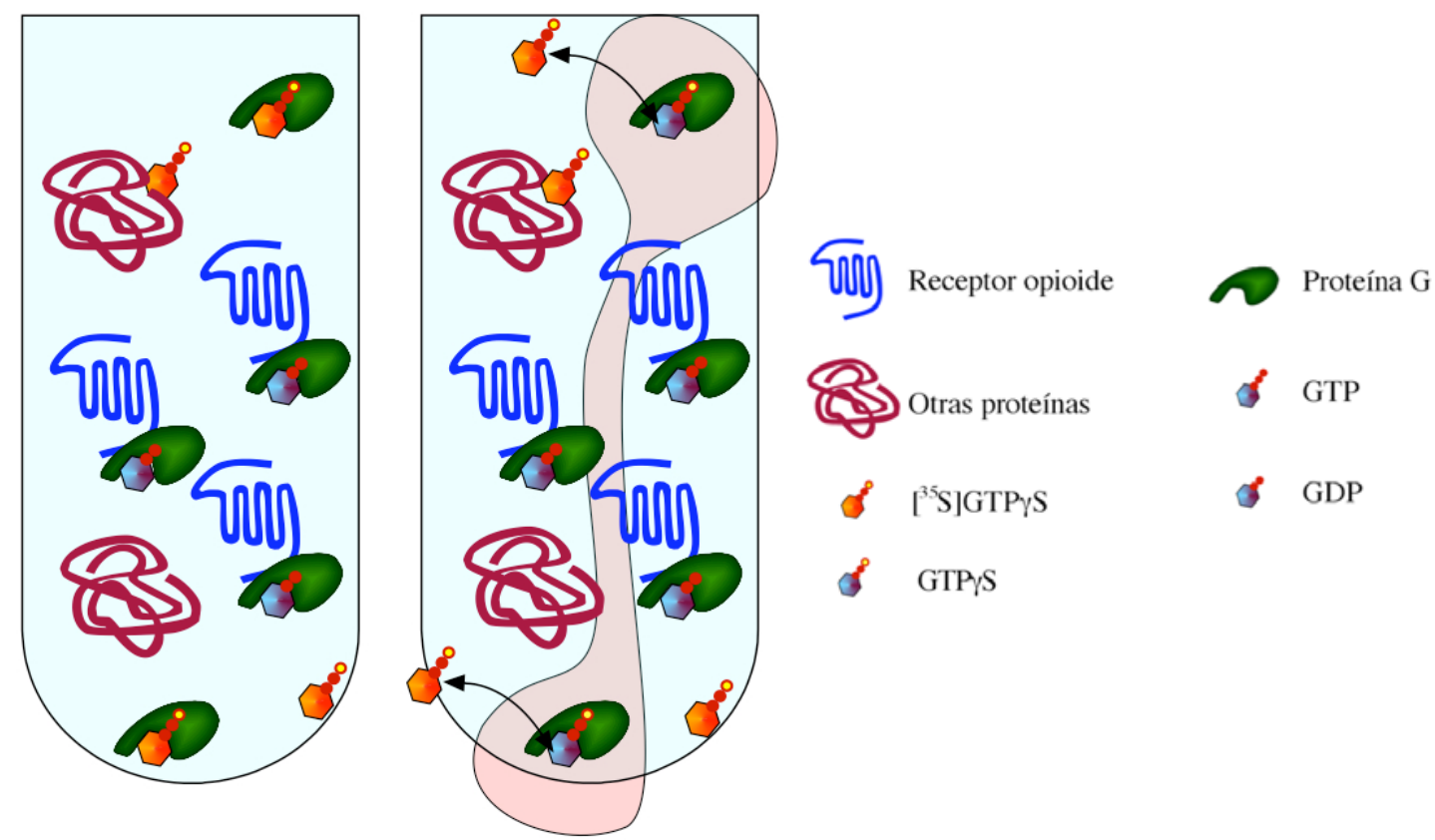

En la situación representada en la figura superior estamos determinando la situación basal, es decir la activación de proteínas G en ausencia de ligando activante. Determinar la activación basal es importante ya que los resultados obtenidos los vamos a expresar como porcentaje de activación frente a la situación basal.

Para poder determinar la activación del receptor por parte de un ligando utilizaremos distintas concentraciones del mismo. Cuanto mayor sea la concentración del ligando mayor será la activación producida hasta llegar a un punto en el que no puede aumentar más la activación. Si representamos los resultados de activación obtenidos, para cada una de las concentraciones de ligando utilizadas, como porcentaje de la activación basal, obtendremos una curva sigmoide de la que podremos calcular el valor de activación máxima, medida de la eficacia del ligando, y la dosis efectiva media $\left(\mathrm{EC}_{50}\right)$, medida de la potencia del ligando. Este último valor lo calcularemos como la concentración de ligando capaz de producir el $50 \%$ de la activación máxima. 


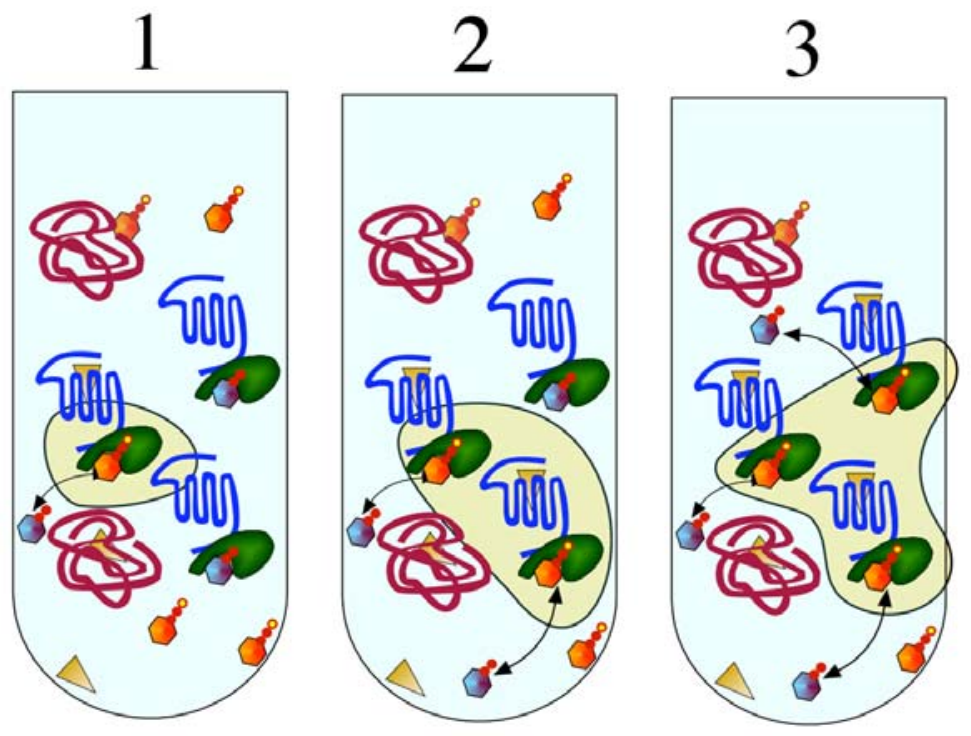

500 Receptor opioide

Droteína G

$\left.{ }^{35} \mathrm{~S}\right] \mathrm{GTP} \gamma \mathrm{S}$

GDP

\% Activación

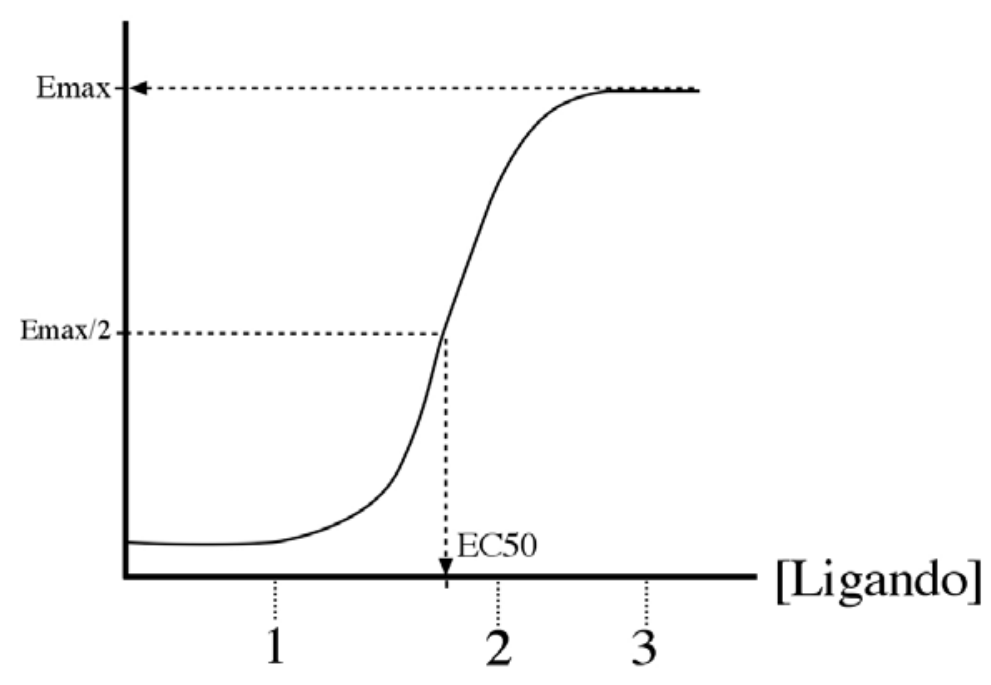


Anexo IV 



\section{Indice de Figuras}

$1 \quad$ Fruto de adormidera 3

2 Papiro de Ebers 4

3 Opio puro 5

$4 \quad$ Fumadero de opio 5

$5 \quad$ Estructura de la morfina y heroína 6

$\begin{array}{lll}6 & \text { Principales alcaloides del opio } & 7\end{array}$

7 Heroína de Bayer 8

8 Aferencias nociceptivas 9

$\begin{array}{lll}9 & \text { Vías nociceptivas } & 10\end{array}$

$\begin{array}{lll}10 & \text { Estructura general de un receptor opioide } & 19\end{array}$

11 Unión diferencial de agonistas y antagonistas 21

12 Comparación de la estructura de la morfina y un péptido opioide 22

13 Relación receptores-péptidos endógenos 24

14 Splicing alternativo del receptor mu de ratón 28

15 Estructura de una proteína G heterotrimérica 30

16 Señalización de los receptores opioides 31

17 Desensibilización e internalización 34

$18 \quad$ Drosophila melanogaster 37

19 Pez cebra 39

20 Estructura genómica de los receptores mu 44

21 Esquema del receptor opioide mu de rata 46

22 Inserción de secuencias mediante PCR 58

23 Eliminación de secuencias mediante PCR 60

24 Esquema secuenciación regiones internas 71

25 Células HEK-293 en cultivo 74

26 Expresión de zfMOR en distintos tejidos 95

$27 \quad$ PCR de zfMOR en gel de agarosa 97

28 Producto purificado zfMOR 98

29 Esquema de la construcción de zfMOR en $\mathrm{pGEM}^{\circledR}{ }_{-\mathrm{t}} \quad 100$

30 Digestión de la construcción de zfMOR en pGEM $^{\circledR}$-t 100

31 Importancia de la dirección del inserto en pcDNA3.1 102 
32 Digestión de la construcción de zfMOR en pcDNA3.1 103

33 Prueba de expresión de zfMOR en células HEK-293 105

$\begin{array}{lll}34 & \text { Prueba funcional zfMOR } & 106\end{array}$

35 Saturación ${ }^{3} \mathrm{H}$-Diprenorfina sobre zfMOR 108

$\begin{array}{lll}36 & \text { Saturación }{ }^{3} \mathrm{H}-\mathrm{DAMGO} \text { sobre zfMOR } & 108\end{array}$

37 Saturación ${ }^{3}$ H-Diprenorfina sobre rMOR 109

38 Saturación ${ }^{3} \mathrm{H}$-DAMGO sobre rMOR 110

39 Desplazamientos ${ }^{3} \mathrm{H}$-Diprenorfina sobre zfMOR 112 y 113

40 Activaciones de proteínas G con distintos compuestos 116

41 Curvas de activación dosis-respuesta de proteínas G 116

42 Curvas de inhibición dosis-respuesta de la adenilato ciclasa 118

43 Curvas de inhibición dosis-respuesta de la adenilato ciclasa 119

44 Aproximación empleada para obtener las construcciones HA y FLAG 122

45 PCR de las construcciones HA y FLAG en gel de agarosa 122

46 Digestión de las construcciónes HA y FLAG en pCR ${ }^{\circledR}$ II-TOPO ${ }^{\circledR} \quad 123$

47 Resumen de plásmidos empleados en las construcciones HA y FLAG 124

48 Digestiones previas a la ligación de las construcciones HA y FLAG 125

49 Placas de transformaciones con control negativo de autoligación 126

50 Comprobación digestión construcciones HA y FLAG acabadas 127

$\begin{array}{lll}51 & \text { Esquema del proceso de mutagénesis dirigida } & 128\end{array}$

52 Aproximación utilizada para obtener el receptor mutante 128

53 Digestión construcciones HA y FLAG mutantes 130

54 Desplazamientos ${ }^{3} \mathrm{H}$-DAMGO sobre zfMOR y mutante 131 y 132

55 Curvas de inhibición dosis-respuesta de la adenilato ciclasa con zfMOR y mutante

56 Curvas de inhibición dosis-respuesta de la adenilato ciclasa con

zfMOR y mutante usando péptidos endógenos 134 y 135

57 Experimentos con $\mathrm{Zn}^{+2} \quad 136$

58 Inmunofluorescencia sobre células HEK-293 con zfMOR (Control) 137

59 Inmunofluorescencia sobre células HEK-293 con zfMOR (DAMGO) 138

60 Inmunofluorescencia sobre células HEK-293 con zfMOR (Etorfina) 139

61 Inmunofluorescencia sobre células HEK-293 con rMOR (Control) 140

62 Inmunofluorescencia sobre células HEK-293 con rMOR (DAMGO) 141

63 Inmunofluorescencia sobre células HEK-293 con rMOR (Etorfina) 142 
64 Inmunofluorescencia sobre células HEK-293 con zfMOR y

células HEK-293 con rMOR (Met-encefalina)

65 Inmunofluorescencia sobre células HEK-293 con zfMOR y

células HEK-293 con rMOR (Morfina)

66 Internalización por FACS puesta a punto del anticuerpo 146

67 Internalización por FACS con distintos compuestos 147

68 Internalización por FACS con naloxona 148

69 Búsqueda del primer exón de zfMOR en NCBI 152

70 Estudio secuencia homóloga al primer exón de zfMOR 153

71 Estudio secuencia homóloga al primer exón de zfMOR (NCBI) 153

72 Búsqueda de los tres exones juntos de zfMOR 154

73 Búsqueda del primer exón de zfMOR en Sanger 154

74 Búsqueda del segundo exón de zfMOR en Sanger 155

75 Búsqueda del tercer exón de zfMOR en Sanger 156

76 Búsqueda de los tres exones juntos de zfMOR en Sanger 157

77 Filograma con distintos tipos de receptores opioides 158

78 Filograma con los receptores tipo mu de distintas especies 160

79 Vesículas con receptor opioide 168

80 Comparación de los lazos extracelulares de los receptores

opioides de tipo mu de humano, ratón, rata y pez cebra 182

81 Dominios importantes para la función del receptor 189

$\begin{array}{lll}82 & \text { Dominio de unión de zinc } & 194\end{array}$

83 Comparación del extremo carboxilo terminal de varios receptores 198 


\section{Indice de Tablas}

$1 \quad$ Clonación de los receptores opioides

2 Precursores y péptidos opioides

3 Selectividad ligandos opioides 26

4 Resultados desplazamientos ${ }^{3} \mathrm{H}$-Diprenorfina sobre zfMOR

5 Resultados de las curvas de activación de proteínas $\mathrm{G}$

6 Resultados de las curvas de inhibición de la adenilato ciclasa

7 Resultados AMPc y desplazamientos con las células HEK-MT

8 Resultados desplazamientos ${ }^{3} \mathrm{H}$-DAMGO sobre zfMOR y mutante

9 Resultados AMPc con péptidos endógenos

10 Porcentaje de homología entre receptores opioides

11 Porcentaje de homología por dominios entre receptores opioides

12 Comparación de nuestros resultados de desplazamientos de

${ }^{3} \mathrm{H}$-Diprenorfina con los de la bibliografía

13 Comparación de nuestros resultados de desplazamientos de

${ }^{3}$ H-DAMGO con los de la bibliografía

14 Comparación de nuestros resultados de activación de proteínas $\mathrm{G}$ con los de la bibliografía

15 Comparación de nuestros resultados de inhibición de la adenilato ciclasa con los de la bibliografía 
